\title{
Abstracts of Technical Papers, Presented at the 107th Annual Meeting, National Shellfisheries Association, Monterey, California, March 22-26, 2015
}

National Shellfisheries Association

Follow this and additional works at: https://scholarworks.wm.edu/vimsarticles

Part of the Aquaculture and Fisheries Commons

\section{Recommended Citation}

National Shellfisheries Association, "Abstracts of Technical Papers, Presented at the 107th Annual Meeting, National Shellfisheries Association, Monterey, California, March 22-26, 2015" (2015). VIMS Articles. 523.

https://scholarworks.wm.edu/vimsarticles/523 


\title{
ABSTRACTS OF TECHNICAL PAPERS
}

\author{
Presented \\ at the \\ $107^{\text {th }}$ Annual Meeting
}

NATIONAL SHELLFISHERIES ASSOCIATION

Monterey, California

March 22-26, 2015 


\section{CONTENTS}

M. Victoria Agnew, Chris Materna, Kathryn Markey, Roxanna Smolowitz

THE USE OF FRESH TISSUE BIOPSY ANALYSIS TO EVALUATE TREMATODE PREVALENCE IN THE GONADS OF THE BLUE MUSSEL, MYTILUS EDULIS $\ldots \ldots \ldots \ldots \ldots \ldots \ldots \ldots \ldots \ldots \ldots \ldots \ldots \ldots \ldots \ldots$

Dalila Aldana Aranda, Martha Enriquez Díaz, Claire Paris-Limouzy

EFFECT OF TIDE AND PHOTOPERIOD ON ABUNDANCE AND DISTRIBUTION OF

LARVAE OF QUEEN CONCH, STROMBUS GIGAS $\ldots \ldots \ldots \ldots \ldots \ldots \ldots \ldots \ldots \ldots$

Bassem Allam, Emmanuelle Pales Espinosa

TOWARDS A FUNCTIONAL CHARACTERIZATION OF EXTRAPALLIAL HEMOCYTES IN

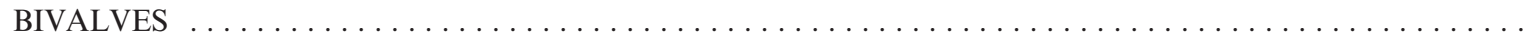

Bassem Allam, Emmanuelle Pales Espinosa

THE MULTIPLE, CENTRAL ROLES OF MUCOSAL SECRETIONS IN MARINE BIVALVES $\ldots \ldots \ldots \ldots$

Brian Allen, Ryan Crim, Betsy Peabody

OLYMPIA OYSTER CULTIVATION FOR RESTORATION PART 2: POST-HATCHERY

PRACTICES AND OUTPLANT CONSIDERATIONS

Per Andersen, Ditte Torring, Per Dolmer, Jonathan Carl

THE SEA GARDENS OF DENMARK - A NEW CONCEPT BASED ON RECREATIONAL

AQUACULTURE ACTIVITIES IN LOCAL DANISH MARINE AND ESTUARINE WATERS . . . . . . . .

Brian Allen, Jonathan Davis

OLYMPIA OYSTER (OSTREA LURIDA) RECRUITMENT WITHIN PUGET SOUND ENHANCEMENT

PROJECT SITES: SUBSTRATE AND DENSITY CORRELATIONS TO

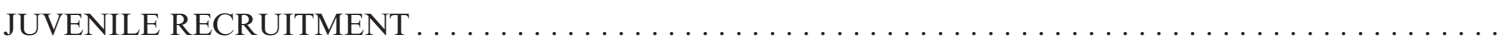

Thomas Anderson, Chuck Adams, Leslie Sturmer

DEVELOPMENT OF A FINANCIAL RISK ANALYSIS TOOL FOR FLORIDA HARD CLAM GROWERS . .

Christopher Andrikos

INTEGRATED MARINE ALGA AND C. VIRGINICA LARVAL REARING COMPARING LIVE

AND CONCENTRATED DIET BLENDS OF THE SAME GENUS

Eugenio Aragón-Noriega

EFFECTS OF FISHERIES IN POPULATION SIZE STRUCTURE OF PANOPEA GLOBOSA FROM

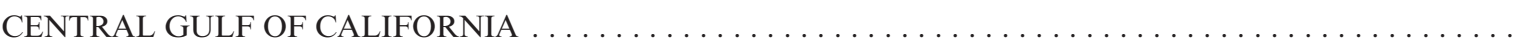

Alberto Arias-Perez, Dennis Hedgecock

SECOND- AND THIRD-GENERATION LINKAGE MAPS REVEAL ERRORS IN THE

ASSEMBLY OF THE PACIFIC OYSTER GENOME $\ldots \ldots \ldots \ldots \ldots \ldots \ldots \ldots \ldots \ldots \ldots \ldots$

David Armstrong, Chris Long, Janet Armstrong, Sean McDonald, Jake Kvistad

THE CONDOR OF COMMERCIAL CRABS: COLLAPSE OF THE BLUE KING . . . . . . . . . . .

Samuel Asci, Kevin Stokesbury

ESTIMATING THE IMPACTS OF FISHING AND RECOVERY IN THE CLOSED AND OPENED

AREAS OF THE GULF OF MAINE, FOCUSING ON SEA SCALLOP MORTALITY

Patrick Azema, Marie-Agnès Travers, Jean-Baptiste Lamy, Lionel Dégremont GENETIC PARAMETERS FOR OSHV-1 AND VIBRIO AESTUARIANUS RESISTANCE IN

CRASSOSTREA GIGAS: FIRST RESULTS USING CONTROLLED CHALLENGES .

Patrick Azema, Marie-Agnès Travers, Lionel Dégremont GENOTYPE BY SIZE INTERACTION FOR OSHV-1 RESISTANCE IN CRASSOSTREA GIGAS . . . . . . .

Patrick Azema, Agnès Travers, Lionel Dégremont

EVALUATION OF RESISTANCE TO VIBRIO AESTUARIANUS THROUGHOUT THREE

SUCCESSIVE CHALLENGES USING CRASSOSTREA GIGAS SELECTED AND UNSELECTED

FOR THEIR HIGHER RESISTANCE TO OSHV-1 $\ldots \ldots \ldots \ldots \ldots \ldots \ldots \ldots \ldots \ldots \ldots \ldots$

Shirley Baker, Alexander Lopeztegui-Castillo, Adriana Artiles-Valor, Yuliesky Garces-Rodriguez, Roberto Castelo-Baez,

Ninieská Castro-Grana

AN INTERNATIONAL COLLABORATION: DOCUMENTING THE NON-NATIVE GREEN MUSSEL, PERNA

VIRIDIS, IN CUBA.

Kehan Bao, Marta Gomez-Chiarri, Dina Proestou

MARKERS ASSOCIATED WITH DISEASE RESISTANCE IN EASTERN OYSTERS,

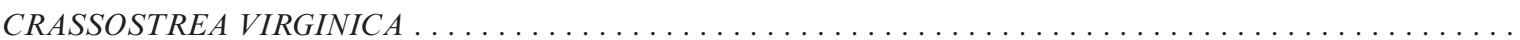


Leila Basti, Tastuya Oda, Kiyohito Nagai, Satoshi Nagai

ROLE OF CYTOTOXICITY AND HEMOLYSIS IN THE DELETERIOUS EFFECTS OF

ALEXANDRIUM AFFINE AND $A$. CATENELLA ON EARLY-LIFE DEVELOPMENT OF THE

JAPANESE PEARL OYSTER, PINCTADA FUCATA MARTENSII $\ldots \ldots \ldots \ldots \ldots \ldots \ldots \ldots \ldots \ldots$

Skylar Bayer, Richard Wahle, Damian Brady, Pete Jumars

DETECTING FERTILIZATION SUCCESS IN ARTIFICIAL DOCKSIDE, MANIPULATED SEABED,

AND NATURAL POPULATION DENSITY GRADIENTS OF SEA SCALLOPS $\ldots \ldots \ldots \ldots \ldots \ldots \ldots \ldots$

Brian F. Beal, Chad Coffin, Clint Goodenow, Sara Randall

GREEN CRAB, CARCINUS MAENAS, POPULATION DYNAMICS IN THE HARRASEEKET RIVER, FREEPORT,

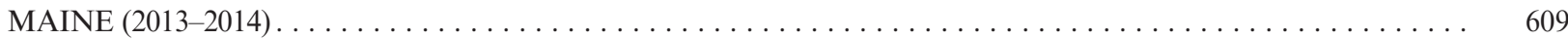

Bonnie J. Becker, Michael D. Behrens, Brian Allen, Brent Vadopalas, Megan Hintz, Hannah Parker WHAT EARLY LIFE HISTORY TELLS US ABOUT RESTORATION SUCCESS IN

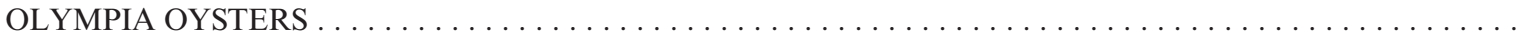

Shai Bejerano, Christine Makdisi, W. Christopher Long, Katherine Swiney, Robert Foy, Gary H. Dickinson EVALUATING THE EFFECTS OF OCEAN ACIDIFICATION ON THE MECHANICS AND STRUCTURE OF SOUTHERN TANNER CRAB MINERALIZED TISSUE $\ldots \ldots \ldots \ldots \ldots \ldots \ldots$

Tal Ben-Horin, Gorka Bidegain, Eric Powell, Dave Bushek OVERFILTRATION OF MARINE DISEASES I: EXPERIMENTAL EVIDENCE AND NOTES

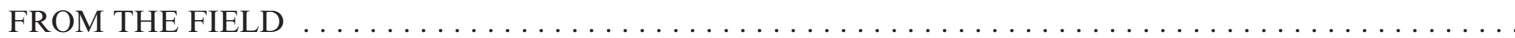

Fiana Bess, Ave Harris, Christopher Welsh, Edward J. Catapane, Margaret A. Carroll PRESENCE OF OCTOPAMINE RECEPTORS IN HEART OF THE EASTERN OYSTER,

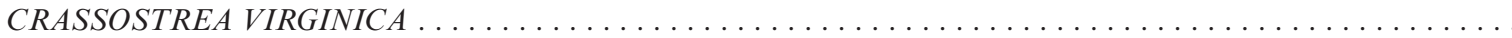

Gorka Bidegain, Tal Ben-Horin, Eric N. Powell, John M. Klinck, David Bushek, Eileen E. Hofmann OVERFILTRATION OF MARINE DISEASES II: COMPARTMENTAL MODELS AND WATER COLUMN SIMULATIONS . .

Amanda Bird, D. Zacherl DETERMINING POPULATION STRUCTURE, REPRODUCTIVE POTENTIAL AND HABITAT ASSOCIATIONS OF THREADED ABALONE IN SOUTHERN CALIFORNIA $\ldots \ldots \ldots \ldots \ldots \ldots \ldots \ldots \ldots$

Thomas Bliss, Justin Manley WILD SPAT COLLECTION, WINTER GROWTH AND SURVIVAL OF SINGLE OYSTERS

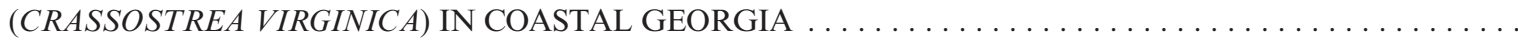

Eleanor Bochenek, Sean Martin, Daphne Munroe, Sarah Borsetti THE DEVELOPING OFFSHORE WHELK (BUCCINUM UNDATUM) FISHERY IN

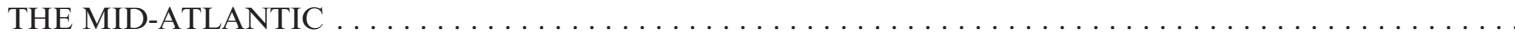

Beatrix Boisette, Ave Harris, Patrick Akande, Edward J. Catapane, Margaret A. Carroll HISTAMINE AND HISTAMINE RECEPTOR INVOLVEMENT IN SENSORY-MOTOR INTEGRATION OF GILL LATERAL CELL CILIA ACTIVITY IN THE BIVALVE, CRASSOSTREA VIRGINICA . .

Rebekah Borgert, James Stoeckel, William Walton, Ken Heck, William Daniels FACTORS AFFECTING VALUE OF OFF-BOTTOM OYSTER AQUACULTURE CAGES AS HABITAT FOR JUVENILE BLUE CRAB

Katelyn M. Bosley, Louise A. Copeman, Brett R. Dumbauld IDENTIFICATION OF THALASSINIDEAN SHRIMP FOOD SOURCES IN AN OREGON ESTUARY USING FATTY ACID ANALYSIS AND STABLE ISOTOPE RATIOS

Katharyn Boyer, Cassie Pinnell, Jen Miller, Julien Moderan, Kevin Stockmann FAUNAL USE AND INTERACTIONS AMONG RESTORED OYSTER REEFS AND EELGRASS AT THE SAN FRANCISCO BAY LIVING SHORELINES: NEARSHORE LINKAGES PROJECT

Hannah Bradford, Shawn Robinson, Bruce MacDonald, Keng Pee Ang, Benjamin Forward, David Thumbi, Thierry Chopin TOWARDS AN UNDERSTANDING OF THE ROLE OF MICROBES IN NUTRIENT DYNAMICS ON SALMON FARMS: IMPLICATIONS FOR INTEGRATED MULTI-TROPHIC AQUACULTURE (IMTA) ... 
S.K. Briley, R.R. Ware, C.R. Whitcraft, D.C. Zacherl

IMPACT OF A CONSTRUCTED OLYMPIA OYSTER RESTORATION PROJECT ON AN ADJACENT

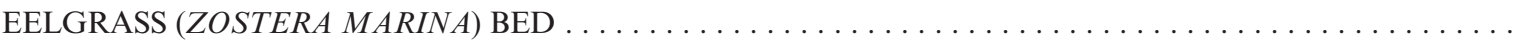

614

Alexandra Brown, Kathryn Markey, Roxanna Smolowitz

DETECTION OF VIBRIO PARAHAEMOLYTICUS AND VIBRIO VULNIFICUS IN OYSTER

TISSUE, SEDIMENT, AND WATER SAMPLES, AND THEIR CORRELATION TO CHLOROPHYLL

LEVELS THROUGHOUT RHODE ISLAND AND MASSACHUSETTS $\ldots \ldots \ldots \ldots \ldots \ldots \ldots$

Mark Brush, Lisa Kellogg, Emily Skeehan

A USER-FRIENDLY, ONLINE MODEL FOR ESTIMATING THE ECOSYSTEM IMPACT OF

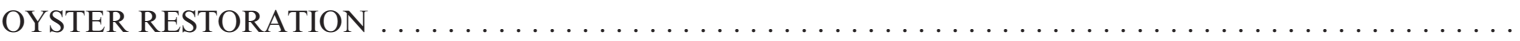

David Bushek, Kathryn Ashton-Alcox, Eric Powell

SUSTAINABLE FISHERY MANAGEMENT AND OYSTER POPULATION ENHANCEMENT:

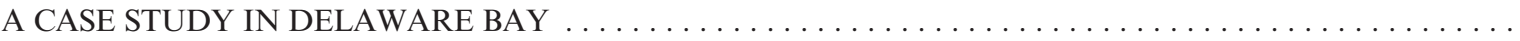

David Bushek, Ryan Carnegie, Lisa Calvo, Robert Rheault, Deborah Bouchard, Marcy Nelson, Karen Hudson,

Lori Gustafson, Lynn Creekmore

STREAMLINING BIOSECURITY MANAGEMENT IN THE CONTEXT OF REGIONAL

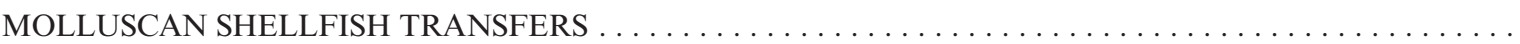

Lisa Calvo, Tal Ben-Horin, David Bushek

EFFECT OF INTERTIDAL EXPOSURE ON VIBRIO PARAHAEMOLYTICUS LEVELS

IN OYSTERS CULTIVATED IN DELAWARE BAY, NEW JERSEY, USA $\ldots \ldots \ldots \ldots \ldots \ldots \ldots$

Jonathan Carl, Per Andersen, Per Dolmer, Ditte Torring, Heidi Timm, Mathilde Pedersen, Michael Larsen,

Anders Pedersen, Marlene Molgaard, Theis Boderskov, Peter Schmedes, Susan Holdt, Goncalo Marinho, Lisbeth Plessner THE EXTRACTION OF NUTRIENTS FROM A DANISH FISH FARM (ONCORHYNCHUS MYKISS)

BY MUSSELS (MYTILUS EDULIS) AND SUGAR KELP (LAMINARIA SACCHARINA):

INTEGRATED MULTI-TROPHIC AQUACULTURE . .

Kyle Cassidy, Kevin Stokesbury

DECLINE OF AMERICAN LOBSTER ABUNDANCE IN BUZZARDS BAY, MASSACHUSETTS

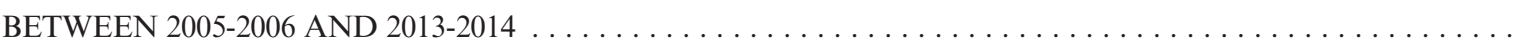

Edward J. Catapane, Margaret A. Carroll

SENSORY MOTOR INTEGRATION OF GILL LATERAL CILIA ACTIVITY IN THE BIVALVE

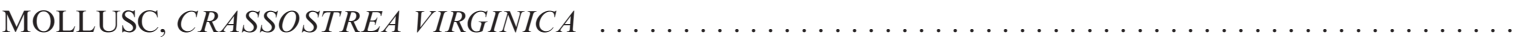

Cynthia Catton, Joanne Lessard, Laura Rogers-Bennett

CHARACTERIZING NORTHERN ABALONE POPULATIONS ACROSS A BROAD GEOGRAPHIC

RANGE: PERSPECTIVES ON ENDANGERED LISTING CONSIDERATION . . . . . . . . . . . .

614

614

615

615

616

era B. S. Chan, Takashi Toyofuku, George Wetzel, Laxmikant Saraf, Vegatensen Thiyagarajan, Andrew S. Mount DIRECT DEPOSITION OF CRYSTALLINE ARAGONITE IN THE CONTROLLED

BIOMINERALIZATION OF THE CALCAREOUS TUBEWORM $\ldots \ldots \ldots \ldots \ldots \ldots \ldots \ldots \ldots$

Andrew L. Chang, Anna K. Deck, Preston D. Malm, Sarikka Attoe, Karissa Willits, Lindsay J. Sullivan, Steven G. Morgan CURRENT AND FUTURE FRESHWATER FLOW CONTROL OF OLYMPIA OYSTER POPULATION DEMOGRAPHY IN THE SAN FRANCISCO ESTUARY $\ldots \ldots \ldots \ldots \ldots \ldots \ldots \ldots$

Kurt Cheng, Danielle Kreeger

THE ASIAN CLAM (CORBICULA FLUMINEA): SEASONAL FILTRATION RATES AND

POPULATION DYNAMICS IN TWO TRIBUTARIES OF THE DELAWARE RIVER $\ldots \ldots \ldots \ldots \ldots \ldots$

Young Ghan Cho, Hyun-Sil Kang, Hyun-Ki Hong, Kwang-Sik Choi

ITS AND 18S RDNA SEQUENCE POLYMORPHISM OF PERKINSUS OLSENI ISOLATES FROM

MANILA CLAM, RUDITAPES PHILIPPINARUM, IN KOREAN WATER $\ldots \ldots \ldots \ldots \ldots$

J. Sook Chung, Karrie Bulski, Anna N. Walker, Richard F. Lee EFFECTS OF DISPERSED AND EMULSIFIED OIL ON MOLTING, ECDYSONE AND ECR/RXR 
Jeff C. Clements, Krystal D. Woodard, Heather L. Hunt CLAMS ON ACID: EXPERIMENTAL EFFECTS OF SEDIMENT ACIDIFICATION ON BURROWING BEHAVIOUR AND DISPERSAL OF JUVENILE SOFT SHELL CLAMS $\ldots \ldots \ldots \ldots \ldots \ldots \ldots \ldots$

Natalie Coleman, Katelyn Bosley, Brett Dumbauld

THE DIRTY SECRET ON BURROWING SHRIMP GROWTH: VERIFICATION OF TWO ALTERNATIVE METHODS OF AGE DETERMINATION IN THE BURROWING SHRIMP NEOTRYPAEA CALIFORNIENSIS .

Ryan J. Corbett, Marta Gomez-Chiarri, Jessica Moss Small, Standish K. Allen, Jr., Dina A. Proestou CHARACTERIZATION OF PHENOTYPIC VARIATION FOR DERMO RESISTANCE AMONG SELECTIVELY-BRED FAMILIES OF THE EASTERN OYSTER, CRASSOSTREA VIRGINICA ...

Jeffrey Cornwell, Michael Owens, Zachary Nickerson, Lisa Kellogg RESTORED OYSTER REEF DENITRIFICATION - EXPERIMENTAL CONSIDERATIONS AND

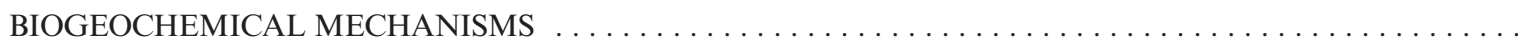

Charlotte Corporeau, Lizenn Delisle, Yanouk Epelboin, Claudie Quéré, Fabrice Pernet METABOLIC SIGNATURES OF THE HERPESVIRUS OSHV-1 $\mu$ VAR IN THE OYSTER: THE

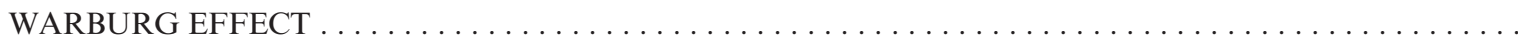

Ryan Crim, Brian Allen, Alex Karpoff, Stuart Ryan, Joth Davis, Brent Vadopalas OLYMPIA OYSTER CULTIVATION FOR RESTORATION PART I: BREEDING AND HATCHERY

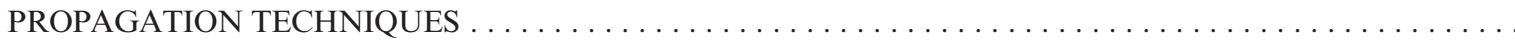

Lisa M. Crosson, Glenn R. VanBlaricom, Samuel J. White, Carolyn S. Friedman GEOGRAPHIC DISTRIBUTION \& QUANTIFICATION OF ABALONE WITHERING SYNDROME (WS-RLO) VIA SEAWATER SURVEYS FROM WILD AND FARMED POPULATIONS ALONG THE CALIFORNIA COAST

Rolando Cruz-Vásquez, Sergio G. Castillo-Vargasmachuca, E. Alberto Aragón-Noriega MODELING THE POSSIBLE EFFECTS OF GLOBAL WARMING IN STOCKS OF PANOPEA

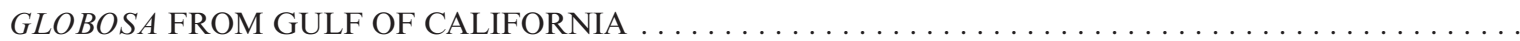

Lyanne J.F. Curtis, Daniel L. Curtis, Haley Matkin, Matthew Thompson, Francis Choi, Paul Callow,

Graham E. Gillespie, Thomas W. Therriault, Christopher M. Pearce SHELLFISH TRANSFERS AS A POTENTIAL VECTOR FOR EUROPEAN GREEN CRABS

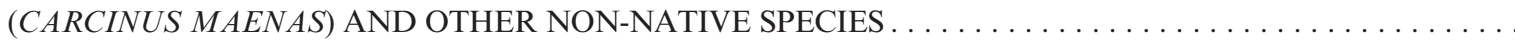

Daniel L. Curtis, Christopher M. Pearce, Paul van Dam-Bates, Lindsay C. Orr, Nicholas M.T. Duprey,

Stephen F. Cross, Laura L.E. Cowan CALIFORNIA SEA CUCUMBERS (PARASTICHOPUS CALIFORNICUS) IN AQUACULTURE: ASSESSING FEASIBILITY, POTENTIAL ECOLOGICAL INTERACTIONS,

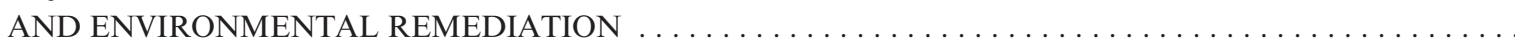

Anthony F. D'Andrea, Elizabeth A. Perotti, Stacy N. Galleher, Cinamon L. Moffett, Stacy A. Strickland CAN SUBTIDAL BAY CLAMS SERVE AS SOURCE POPULATIONS FOR THE INTERTIDAL? A PRELIMINARY EVALUATION OF THE SUBTIDAL "SPAWNING STOCK HYPOTHESIS” IN TWO OREGON ESTUARIES

Cécile Dang, Christopher F. Dungan, Gail P. Scott, Kimberly S. Reece PERKINSUS SP. INFECTIONS AND IN VITRO ISOLATES FROM ANADARA TRAPEZIA MUD ARKS OF QUEENSLAND, AUSTRALIA

Lewis Deaton THE EFFECT OF NEUROTRANSMITTERS ON ISOLATED VENTRICLES OF THE GREEN MUSSEL, PERNA VIRIDIS . . .

Lewis Deaton CARBOHYDRASE ACTIVITY IN THE DIGESTIVE GLANDS OF TWO FRESHWATER MOLLUSCS: POMACEA MACULATA AND MARGARITIFERA HEMBELI .................

Julie Decker, Katharine Wellman

ALASKA MARICULTURE INITIATIVE - WHY NOT ALASKA? SIX ECONOMIC CASE STUDIES OF SUCCESSFUL MARICULTURE INDUSTRIES AND THEIR POTENTIAL RELATIONSHIP TO A STATEWIDE STRATEGIC PLAN TO DEVELOP THE ALASKAN INDUSTRY 
Caitlin DelSesto, Jillon McGreal, Marta Gomez-Chiarri, Roxanne Smolowitz, Gary Wessel ASSESSING THE PRESENCE AND IMPACT OF DENSOVIRUS ON SEA STAR WASTING

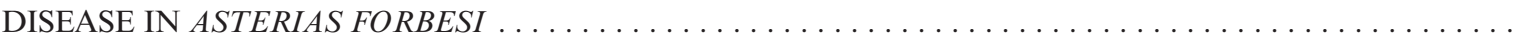

Gary H. Dickinson, Conall G. McNicholl, Beatriz, Orihuela, Daniel Rittschof ASSESSING THE EFFECT OF SALINITY ON BARNACLE ADHESION AND BIOMINERALIZATION .... Yinghui Dong, Zhihua Lin MOLECULAR CHARACTERIZATION AND QUANTITATIVE EXPRESSION ANALYSIS OF MYOSTATION GENE FROM THE BLOOD CLAM, TEGILLARCA GRANOSA . . . . . . . . .

Catherine Drake, Jonathan Geller DECORATING BEHAVIOR IN LOXORHYNCHUS CRISPATUS AND CONSEQUENCES OF POSSIBLE MUTUALISMS FROM LIVING ON A MOBILE ENVIRONMENT

Dumbauld, Lee McCoy, Katelyn Bosley, John Chapman DOES RECRUITMENT DRIVE FLUCTUATIONS IN BURROWING SHRIMP POPULATIONS

IN U.S. WEST COAST ESTUARIES AND AFFECT SHELLFISH AQUACULTURE? . .

Evan Durland, Blaine Schoolfield, Chris Langdon THE MOLLUSCAN BROODSTOCK PROGRAM - IMPROVING PACIFIC OYSTERS FOR WEST COAST FARMERS THROUGH SELECTIVE BREEDING $\ldots \ldots \ldots \ldots \ldots \ldots \ldots \ldots \ldots \ldots$

Kari A. Eckdahl, Danielle C. Zacherl BLACK ABALONE (HALIOTIS CRACHERODII) ABUNDANCE AND HABITAT AVAILABILITY

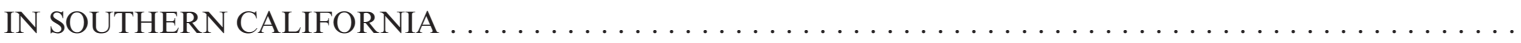

Robert Eckert SPATIAL PATTERNS OF SPAT DENSITY IN RELATION TO DISTANCE FROM NATIVE OYSTER REEFS IN GREAT BAY ESTUARY, NEW HAMPSHIRE $\ldots \ldots \ldots \ldots \ldots \ldots \ldots \ldots \ldots$ Stephen Eddy, Mary Ellen Camire, Ung Wei Kenn GONAD YIELDS AND SENSORY ATTRIBUTES OF GREEN SEA URCHINS FOLLOWING ENHANCEMENT FEEDING WITH EITHER DRIED KELP, FRESH KELP,

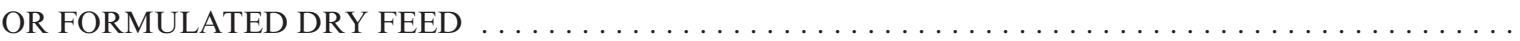

Douglas J. Eernisse, Ryan N. Crim, Erik M. Pilgrim MOST PUGET SOUND OLYMPIA OYSTERS (OSTREA LURIDA) BELONG TO A NORTHERN

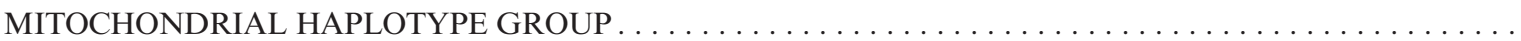

Eman El-Wazzan, Bahaa Abdella, Doaa Ghareeb, Nermeen A. El-Sersy INDUCED HSP70 EXPRESSION IN THE CARPET SHELL CLAM, TAPES DECUSSATUS, ENHANCES RESISTANCE AND IMMUNITY AGAINST MICROCOCCUS LUTEUS . . . . . . . . . . . .

Michael Espinoza, Jennica Castillo, Thomas Parker, John Berriman, Lilly Sam, Ernesto Casillas ,

Sarah Pfrmmer, Ricky Atallah, Danielle Zacherl ASSESSING LONG-TERM TEMPORAL AND SPATIAL VARIATION IN SETTLEMENT OF OSTREA LURIDA IN NEWPORT BAY, CALIFORNIA

Elizabeth Falwell, Marta Gomez-Chiarri, Andrew S. Mount

THE ROLE OF CVIMMP IN DIAPEDESIS AND WOUND HEALING IN THE EASTERN OYSTER ...... .

Jeffrey Fisher, Marlene Meaders, Scott Luchessa SUSPENDED SEDIMENT RISKS AND SEDIMENT METALS ASSOCIATED WITH

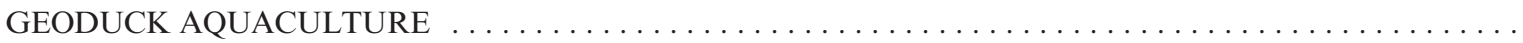

Brittany Flittner, Lisa Milke, Renee Mercaldo-Allen DEVELOPMENT OF A HIGH THROUGHPUT MICROPLATE METHOD FOR THE DETERMINATION OF LARVAL BIVALVE RESPIRATION RATES IN OCEAN ACIDIFICATION STUDIES

Yadira Flores, Renata D'Agrella, Rebecca Grella, Dianna Padilla SNAIL MEETS CRAB: THE EFFECTS OF CHEMICAL CUES OF HEMIGRAPSUS SANGUINEOUS, THE ASIAN SHORE CRAB, ON THE PHENOTYPIC PLASTICITY OF THE ATLANTIC SLIPPERSNAIL, CREPIDULA FORNICATA 
Amy Fowler, Tanya Darden, John Robinson, Peter Kingsley-Smith

A POPULATION ASSESSMENT OF HORSESHOE CRABS (LIMULUS POLYPHEMUS)

IN SOUTH CAROLINA, USA, USING AN INTEGRATED APPROACH $\ldots \ldots \ldots \ldots \ldots \ldots \ldots$

Ruth Francis-Floyd, Roy Yanong, Jan Landsberg, Shirley Baker, Yasu Kiryu, Tom Waltzek,

Deborah Pouder, Mark Flint, Nicole Stacy, Roxanna Smolowitz, Greg Beck, William Sharp

DEVELOPMENT OF DIAGNOSTIC PROTOCOLS FOR HEALTH ASSESSMENT OF

LONG-SPINED SEA URCHINS, DIADEMA ANTILLARUM, IN FLORIDA $\ldots \ldots \ldots \ldots \ldots \ldots \ldots$

Bernard Friedman

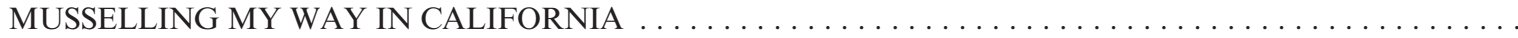

Cristina Fuentes, Alejandra Garcia, Christine Whitcraft, Danielle Zacherl

OLYMPIA (OSTREA LURIDA) AND JAPANESE (CRASSOSTREA GIGAS) OYSTER

RECRUITMENT ONTO A CONSTRUCTED OYSTER BED IN ALAMITOS BAY, CA $\ldots \ldots \ldots \ldots \ldots \ldots$

Marine Fuhrmann, Bruno Petton, Fabrice Pernet DISEASE TRANSMISSION AND ASSOCIATED MORTALITIES OF PACIFIC OYSTER

(CRASSOSTREA GIGAS): DOES SALINITY MATTER?

630

631

Galindo-Sánchez C. E., I. Leyva, F. Lafarga De La Cruz, A. Lago-Leston, F. Díaz,

A.D. Re, C. Gallardo-Escárate

TRANSCRIPTOMIC ANALYSIS OF THE THERMAL STRESS RESPONSE IN

CHRONIC AND ACUTE CONDITIONS IN PANOPEA GLOBOSA JUVENILES . . . . . . . . . . . . . .

Zaul Garcia-Esquivel, Alejandra Ferreira-Arrieta, Fabiola G. Arcos-Ortega,

Carmen Rodriguez-Jaramillo, Ivone Giffard

INTERNAL ANATOMY AND BIOCHEMICAL CONTENT OF THE CORTEZ

GEODUCK, PANOPEA GLOBOSA, DURING LARVAL DEVELOPMENT

Tamara Gaspar, Amy Ringwood

PLASTIC PARTICLE UPTAKE BY OYSTERS, CRASSOSTREA VIRGINICA . . . . . . . . . . . . .

Tessa Getchis, Nancy Balcom, Anoushka Concepcion, Sylvain DeGuise, Julie Rose

THE CONNECTICUT SHELLFISH INITIATIVE: BUILDING ON THE PAST TO

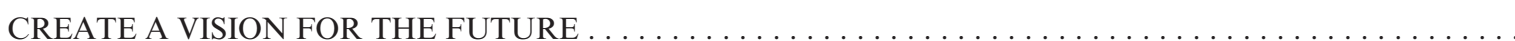

Tessa Getchis, Deborah A. Bouchard, Joseph Buttner, John Ewart, Ann Faulds, George E. Flimlin,

Doris Hicks, Craig Hollingsworth, Andrew Lazur, Dale Leavitt, Dennis McIntosh, Dana L. Morse,

Tom Rippen, Gregg Rivara, Roxanna Smolowitz, Dan Terlizzi, Don Webster, Michael Chambers,

Diane C. Murphy, Robert Pomeroy, Josh Reitsma; Michael A. Rice, Nataliya Plesha

A NEW RESOURCE TO AID IN THE IDENTIFICATION AND MANAGEMENT OF

AQUACULTURE PRODUCTION HAZARDS

Sergio Scarry González-Peláez, Carmen Rodríguez-Jaramillo, J. Jesús Bautista-Romero,

Enrique Morales-Bojórquez, Ma. Teresa Sicard-González, Salvador Emilio Lluch-Cota,

Eduardo Romero-Vivas, Daniel Bernado Lluch-Cota

EFFORT AND STRATEGY REPRODUCTIVE OF GEODUCK, PANOPEA GLOBOSA (DALL, 1898) . . . . . .

Sergio S. González-Peláez, Enrique Morales-Bojórquez, Viridiana Y. Zepeda-Benitez, Alberto Espino-Calderín,

Guadalupe Muñoz-Urruela

GROWTH MODELLING FOR EARLY STAGES OF GEODUCK, PANOPEA GLOBOSA,

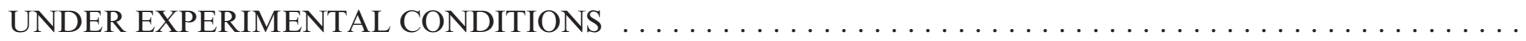

Sergio Scarry González-Peláez, Liliana Carvalho-Saucedo, Alberto Espino-Calderín,

Carlos Rangel-Dávalos, Daniel Bernardo Lluch-Cota

LARVAL DEVELOPMENT OF THE SUBTROPICAL GEODUCK, PANOPEA GLOBOSA

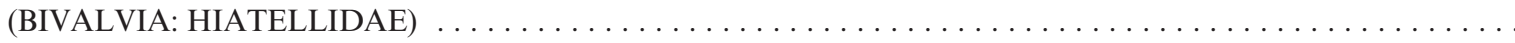

Jacob Goodwin, Elizabeth North, Kennedy Paynter, Anne Handschy INVESTIGATING PHYSIOLOGICAL AND ECOLOGICAL EFFECTS OF REEF

BALLS ON OYSTER (CRASSOSTREA VIRGINICA) POPULATIONS 
Jacob Goodwin, Elizabeth North

USING A NOVEL AUTOMATED IDENTIFICATION TECHNIQUE TO ENHANCE

UNDERSTANDING OF EASTERN OYSTER (CRASSOSTREA VIRGINICA) LARVAL

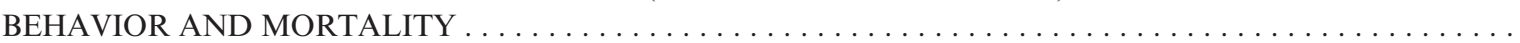

Erin Graham, Brett Dumbauld, Lee McCoy

SEA LEVEL RISE AND SEAGRASS EXPANSION IN WILLAPA BAY, WA: HOW

WILL CHANGES IN ZOSTERA MARINA DISTRIBUTION INFLUENCE AQUACULTURE? . . . . . . . . .

Matthew Gray, Chris Langdon

FEEDING PHYSIOLOGY OF THE NATIVE OLYMPIA OYSTER (OSTREA LURIDA)

AND THE INTRODUCED PACIFIC OYSTER (CRASSOSTREA GIGAS): IMPLICATIONS

FOR ECOSYSTEM SERVICES AND RESTORATION

Matthew Gray, Sean Kramer, Chris Langdon

A NOVEL DUAL BEAD TECHNIQUE FOR EVALUATING THE FEEDING PHYSIOLOGY

AND BEHAVIOR OF BIVALVE LARVAE

Shadaesha Green, J. Sook Chung

UNDERSTANDING THE REPRODUCTIVE ENDOCRINOLOGY OF THE RED

DEEP-SEA CRAB, CHACEON QUINQUEDENS: IDENTIFICATION OF REPRODUCTIVE

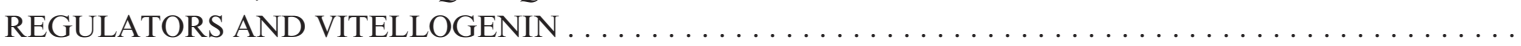

Emma Green-Beach, Richard Karney

OF MARSH AND MUSSELS: PILOT SCALE LIVING SHORELINE IMPLEMENTATION

ON MARTHA'S VINEYARD, MASSACHUSETTS $\ldots \ldots \ldots \ldots \ldots \ldots \ldots \ldots \ldots \ldots \ldots \ldots \ldots$

D. Grosholz, J. Bible, E. Ceballos, A.L. Chang, B.S. Cheng,

A. Deck, M. Ferner, M. Latta, K. Wasson, C. Zabin

UNDERSTANDING ENVIRONMENTAL CONDITIONS THAT SUPPORT SUSTAINABLE

OLYMPIA OYSTER POPULATIONS: INFORMING RESTORATION AND CONSERVATION ........

Ximing Guo

RESILIENCE OF THE OYSTER SEEN THROUGH ITS GENOME $\ldots \ldots \ldots \ldots \ldots \ldots \ldots \ldots \ldots$

Boze Hancock, Line zu Ermgassen, Robert Brumbaugh, Bryan DeAngelis, Jennifer Greene,

Mark Spalding, Elizabeth Scheuster

HOW MUCH IS ENOUGH? USING ECOSYSTEM SERVICES TO SET OBJECTIVES

FOR OYSTER HABITAT RESTORATION

Anne Handschy, Matthew Spitznagel, Kennedy Paynter

EFFECTS OF ARTIFICIAL SUBSTRATE TYPE AND REEF HEIGHT ON THE SURVIVAL

OF OYSTERS IN THE CHOPTANK RIVER, MARYLAND, USA $\ldots \ldots \ldots \ldots \ldots \ldots \ldots \ldots \ldots$

Adi Hanein, Jerry Borchert

WHAT HAS BEEN HAPPENING OVER THE YEARS? DELVING DEEPER INTO BIOTOXIN

AND PHYTOPLANKTON MONITORING IN WASHINGTON STATE

Matthew P. Hare

GENOMIC AND TRANSCRIPTOMIC EVIDENCE FOR FUNCTIONAL OYSTER

DIFFERENTIATION WITHIN SINGLE ESTUARIES $\ldots \ldots \ldots \ldots \ldots \ldots \ldots \ldots \ldots \ldots \ldots \ldots$

Matthew P. Hare

REBUILDING A DIVERSE OYSTER POPULATION: SHOULD WE PLANT GENERALIST OR

SPECIALIST OYSTERS?

Ave Harris, Jarreau Harrison, Fabienne Mondelus, Edward Catapane, Margaret Carroll

HISTAMINE RECEPTORS IN GILL OF THE BIVALVE, CRASSOSTREA VIRGINICA, AND THE

ACTIONS OF HISTAMINE AT GILL INTERFILAMENTAL JUNCTIONS

Lesli Haynes, Patricia Goodman, Patricia Gorman, Barbara Welch, Aswani Volety ECOLOGICAL CONDITION AND VALUE OF OYSTER REEFS OF THE SOUTHWEST

FLORIDA SHELF ECOSYSTEM 
Jake Heare, Brady Blake, Jonathon P. Davis, Brent Vadopalas, Steven B. Roberts EVIDENCE OF OSTREA LURIDA (CARPENTER, 1864) POPULATION STRUCTURE

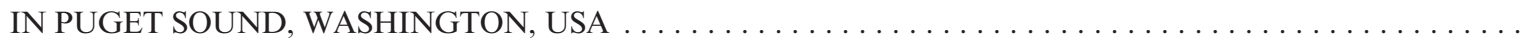

José Angel Hidalgo-de-la-Toba, Sergio Scarry González-Peláez, Enrique Morales-Bojórquez,

J. Jesús Bautista-Romero, Daniel Bernardo Lluch-Cota INDIVIDUAL GROWTH PROFILES AS ALTERNATIVE TO THE TERMINAL SIZE-AT-AGE METHOD IN PANOPEA GENEROSA STUDIES $\ldots \ldots \ldots \ldots \ldots \ldots \ldots \ldots \ldots \ldots$

Colleen Higgins, Bonnie Brown MICROBIAL CONSORTIA ASSOCIATED WITH SEDIMENT NITROGEN REMOVAL AT OYSTER AQUACULTURE SITES IN CHESAPEAKE BAY $\ldots \ldots \ldots \ldots \ldots \ldots \ldots \ldots \ldots \ldots \ldots \ldots$

Laura Hinchliff, Jaimie Dick, Julia Sigwart, Lynn Gilmore BEHAVIOURAL AND PHYSIOLOGICAL EFFECTS OF CONDITIONS ASSOCIATED WITH HANDLING AND TRANSPORT ON BERRIED VELVET SWIMMING CRABS (NECORA PUBER)

Laura Hoberecht ACTIONS TO INCREASE, RESTORE, AND PROTECT SHELLFISH RESOURCES THROUGH THE WASHINGTON SHELLFISH INITIATIVE $\ldots \ldots \ldots \ldots \ldots \ldots \ldots \ldots \ldots \ldots \ldots \ldots$

Hyun-Ki Hong, Young Ghan Cho, Hyun-Sil Kang, Kwang-Sik Choi EFFECT OF AIR EXPOSURE STRESS ON HEMOCYTE PARAMETERS OF THE VARIOUSLY COLORED ABALONE, HALIOTIS DIVERSICOLOR (REEVE, 1846) . . . . . . . . . . . . .

Bobbi Hudson, Thom Allen, Danna Moore SHELLFISH FARMING IN THE PACIFIC NORTHWEST: PUBLIC AND STAKEHOLDER PERCEPTIONS . Inglis, Árni Kristmundsson, Mark Freeman, Kevin Stokesbury APICOMPLEXAN INFECTION CAUSING GRAY MEAT IN THE ATLANTIC SEA SCALLOP, PLACOPECTEN MAGELLANICUS .

Katherine Jackson, Brent Vadopalas, Brian Allen, Steven Roberts USING MICROSATELLITE MARKERS TO COMPARE RESTORATION BREEDING METHODS FOR THE OLYMPIA OYSTER $($ OSTREA LURIDA $\ldots \ldots \ldots \ldots \ldots \ldots \ldots \ldots$

Whitney Jaillet, Carlton Huntsberger, Roxanna Smolowitz, Ronald Smolowitz THE MOLECULAR IDENTIFICATION OF ICHTHYOPHONUS HOFERI AND ICHTHYOPHONUS IRREGULARIS IN YELLOWTAIL FLOUNDER, LIMANDA FERRUGINEA, FROM GEORGES BANKS . . .

Whitney Jaillet, Kathryn Markey, Roxanna Smolowitz ASSESSING THE ACCURACY AND APPLICABILITY OF POOLING OYSTER TISSUES TO REDUCE THE COST OF PERKINSUS MARINUS DIAGNOSTICS .

H.M. Jansen, A. Handa, P. Cranford, R. Bannister, M. Bergvik, O.J. Broch, S. Forbord,

V. Husa, Y. Olsen, K.I. Reitan, J. Skjermo, Ø. Strand EXPLOITATION OF NUTRIENTS FROM SALMON AQUACULTURE: WHAT IS THE POTENTIAL FOR IMTA IN NORWAY?

Mary Beth Johnstone, Neeraj V. Gohad, Elizabeth Falwell, Douglas C. Hansen,

Andrew S. Mount, Karolyn M. Hansen CELLULAR ORCHESTRATED BIOMINERALIZATION OF CRYSTALLINE COMPOSITES ON IMPLANT SURFACES BY THE EASTERN OYSTER, CRASSOSTREA VIRGINICA . . . . . . . . .

Jonas P. Jonasson THE SLOW RECOVERY OF THE ICELAND SCALLOP (CHLAMYS ISLANDICA) FISHERY

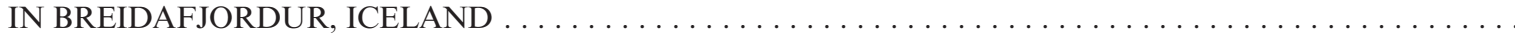
Christy Juhasz, Laura Rogers-Bennett TRACKING THE ABUNDANCE OF DUNGENESS CRAB MEGALOPAE IN CALIFORNIA - POTENTIAL INDEX FOR FUTURE FISHERY CATCHES 
Andrew S. Kane, Ross M. Brooks, Felipe E. Sanchez, Jason H. Byrd, Rachel Touroo,

Shannon Hartsfield, Karl E. Havens LOOK DEEP INTO MY SHELL: SHELL PARASITISM AND RADIOGRAPHY OF

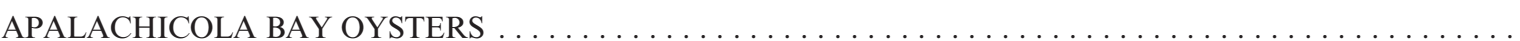

Hyun-Sil Kang, Hyun-Ki Hong, Hee-Do Jeong, Kwang-Sik Choi PATHOLOGY SURVEY OF RUDITAPES PHILIPPINARUM DURING THE

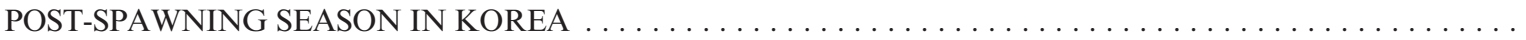

Hyun-Sil Kang, Hyun-Ki Hong, Kyung-Il Park, Kwang-Sik Choi THE VARIEGATED CARPET SHELL, RUDITAPES VARIEGATUS, (SOWERBY, 1852)

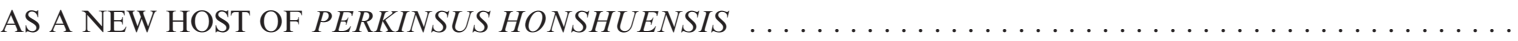

Caihuan Ke, Guilan Di, Weiwei You, Xuan Luo PERSPECTIVES ON MECHANISMS OF ABALONE HETEROSIS: EVIDENCE FROM PROTEOMICS APPROACH

M. Lisa Kellogg, Jeffrey C. Cornwell, Michael S. Owens NITROGEN REMOVAL ASSOCIATED WITH OYSTER REEFS AND OYSTER AQUACULTURE .......

Bushra Khan, Sandra M. Clinton, Timothy J. Hamp, James D. Oliver, Amy H. Ringwood RESPONSES OF OYSTER MICROBIOMES TO HYPOXIA $\ldots \ldots \ldots \ldots \ldots \ldots \ldots \ldots \ldots \ldots \ldots \ldots \ldots$

Bushra Khan, Amy Ringwood EFFECTS OF HYPOXIA ON METAL BIOAVAILABILITY AND TISSUE DAMAGE IN EASTERN OYSTERS AND RIBBED MUSSELS

Peter Kingsley-Smith, Benjamin Stone, Blaik Keppler, John Leffler EXPANDING LIVING SHORELINES THROUGH STAKEHOLDER-DRIVEN SITE SELECTIONS FOR INTERTIDAL OYSTER REEF BUILDING IN THE ACE BASIN NERR, SOUTH CAROLINA, USA

Sarah E. Kingston, Jenna Watling, Benjamin Eisenberg, David Carlon GENOTYPE AND PHENOTYPE IN A CHANGING OCEAN: CAN STANDING GENETIC VARIATION IN STRESS RESPONSES RESCUE MUSSEL POPULATIONS FROM THE NEGATIVE IMPACTS OF CLIMATE CHANGE?

Stephanie L. Kiriakopolos, Chela J. Zabin, Lara Martin, Rena Obernolte, Robert Abbott, Edwin D. Grosholz VARIATION IN NATIVE OYSTER (OSTREA LURIDA) PERFORMANCE BETWEEN AND WITHIN TWO RESTORATION SITES IN SAN FRANCISCO BAY $\ldots \ldots \ldots \ldots \ldots \ldots \ldots \ldots$

Alexa Kretsch, Dan Georgianna, Kevin D.E. Stokesbury SURFCLAM SURVEY STRATEGIES

Michael Kuschner, Mark Brush A SYSTEM-LEVEL MODELING TOOL TO PREDICT CARRYING CAPACITY AND ECOSYSTEM IMPACTS IN LARGE-SCALE, BIVALVE-DOMINATED, AGRO-ECOSYSTEMS: APPLICATION TO NORTHERN QUAHOG (= HARD CLAM; MERCENARIA MERCENARIA) AQUACULTURE IN CHERRYSTONE INLET, VA .... .

Jerome La Peyre, Sandra Casas, Jaren Lee, Julie Gauthier, Jean-Philippe Beguel, Qinggang Xue ROLE OF A NOVEL PLASMA IRON BINDING PROTEIN IN EASTERN OYSTER HOST DEFENSE AGAINST PERKINSUS MARINUS $\ldots \ldots \ldots \ldots \ldots \ldots \ldots \ldots \ldots \ldots$

Jerome La Peyre, Sandra Casas, Qinggang Xue, Scott Miles THE COMBINED EFFECTS OF OIL AND SALINITY ON EASTERN OYSTERS $\ldots \ldots \ldots \ldots \ldots \ldots \ldots$ y Lane, Kennedy T. Paynter, Thomas J. Miller ELEVATED $p \mathrm{CO}_{2}$ CAUSES SLOWED GROWTH IN JUVENILE BLUE CRAB (CALLINECTES SAPIDUS) FROM THE PATUXENT RIVER, CHESAPEAKE BAY . . . . . . . . . . . .

Chris Langdon, Evan Durland, Blaine Schoolfield SELECTIVE BREEDING OF PACIFIC OYSTERS IN A CHANGING ENVIRONMENT

Stanley A. Langevin, Colleen A. Burge, Lisa M. Crosson, Samuel J. White, Carolyn S. Friedman SEQUENCE ANALYSIS OF THE PHAGE INFECTING THE WITHERING SYNDROME RICKETTSIA REVEALS A NOVEL BACTERIOPHAGE 
Suan Laramore, Naomi Huntley

EFFECTS OF SALTWATER INTRUSION ON NATIVE AND EXOTIC APPLE SNAILS,

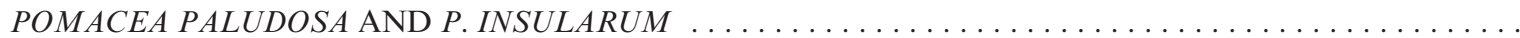

Romain Lavaud, Megan LaPeyre, Sandra M. Casas Liste, Cédric Bacher, Jerome La Peyre QUANTIFYING PHYSIOLOGICAL RESPONSE OF EASTERN OYSTER, CRASSOSTREA VIRGINICA, TO REGIONAL ENVIRONMENTAL VARIABILITY USING THE DYNAMIC

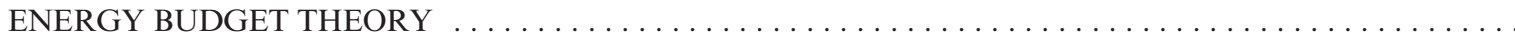

Dale Leavitt, Matthew Griffin DOES THE FLIP BAG IMPROVE OYSTER GRADE AND QUALITY $\ldots \ldots \ldots \ldots \ldots \ldots$

Megan Levesque, Kevin Stokesbury, Susan Inglis MORTALITY ASSESSMENT OF GRAY MEAT DISEASE IN SEA SCALLOPS

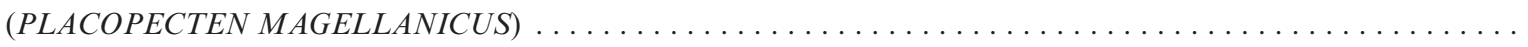

Jeffrey Levinton, Daria Sebastiano, Michael Doall, Shauna Kamath AQUACULTURE APPROACH TO OYSTER NITROGEN REMOVAL: IS THERE A

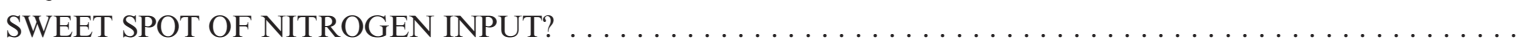

Cui Li, Ximing Guo TRANSCRIPTOME ANALYSIS OF THE RESPONSE TO AIR EXPOSURE AND COLD

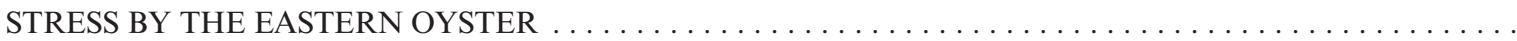

A. Lillis, D. Eggleston, D. Bohnenstiehl CAN YOU HEAR ME NOW?: SOUNDSCAPE MANIPULATION ENHANCES

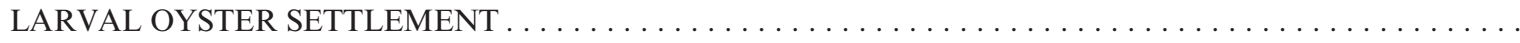

Scott Lindell, Bill Silkes, Adam Silkes, Mason Silkes, David Bailey MUSSEL FARMING IN STATE AND FEDERAL WATERS OF SOUTHERN NEW ENGLAND . . . . . . . . .

Scott Lindell, Jang Kim, Emma Green Beach, David Bailey, Morgan Beals, Charles Yarish MULTI-CROPPING SEAWEED, GRACILARIA TIKVAHIAE, WITH OYSTERS FOR NUTRIENT BIOEXTRACTION AND SEA VEGETABLES IN WAQUOIT BAY, MASSACHUSETTS . . . . . .

JoAnne Linnenbrink, Ryan Walter, Danielle Zacherl, Doug Eernisse GENETIC POPULATION STRUCTRE OF THE OLYMPIA OYSTER, OSTREA LURIDA, IN

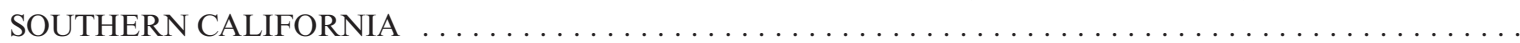

Ming Liu, Susan Ford, David Bushek, Ximing Guo GENETIC VARIATION IN SUSCEPTIBILITY OF THE EASTERN OYSTER TO PERKINSUS MARINUS . .

Yan Liu, Junzeng Xue, Junda Lin, Huixian Wu INVASION AND MORPHOLOGICAL VARIATION OF THE NON-INDIGENOUS BARNACLE CHTHAMALUS CHALLENGERI (HOEK, 1883) IN YANGSHAN PORT AND ADJACENT SEA AREAS . . . . . . . . 654

Kurt Loney-Walsh, Loren Dubose, Margaret A. Carroll, Edward J. Catapane P-AMINOSALICYLIC ACID (PAS) REVERSES NEUROTOXIC EFFECTS OF MANGANESE ON DOPAMINE POST-SYNAPTIC RECEPTORS

W. Christopher Long, Katherine Swiney, Robert Foy EFFECTS OF OCEAN ACIDIFICATION ON SOUTHERN TANNER CRAB LARVAE: CARRYOVER EFFECTS FROM OOGENESIS AND EMBRYOGENESIS ARE STRONGER

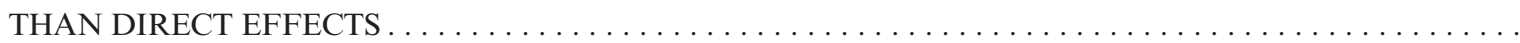

Matthew Lowder, Bushra Khan, Annie Jacob, Kimani Kimbrough, Ed Johnson, Amy Ringwood ZEBRA MUSSELS AS BIOINDICATORS OF HABITAT QUALITY IN THE GREAT LAKES, USA .......

Abby Lunstrum, Ashley Smyth, Karen McGlathery INCREASED SEDIMENT DENITRIFICATION AT AN OFF-BOTTOM OYSTER AQUACULTURE SITE IN CHESAPEAKE BAY

Richard Lutz IDENTIFICATION OF LARVAL AND POST-LARVAL BIVALVES: A MONOGRAPH IN PROGRESS . . . . 656

Kristen Lycett, Joseph Pitula DISEASE ECOLOGY OF THE BLUE CRAB AND ITS PARASITE, HEMATODINIUM PEREZI, IN THE MARYLAND AND VIRGINIA COASTAL BAYS 
Athena Maguire, Karina Nielsen, Laura Rogers-Bennett

A CRYPTIC INFESTATION OF CONCERN: A BLOOD-SUCKING ECTOPARASITIC SNAIL,

EVALEA TENUISCULPTA, INFESTS WILD AND AQUACULTURED RED

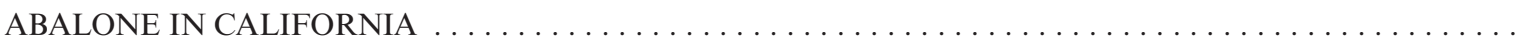

Richard Malloy Jr., Kevin D. E. Stokesbury, N. David Bethoney, Susan Inglis COMPARING VIDEO SURVEY SEDIMENT AND JUVENILE SEA SCALLOP OBSERVATIONS WITH A MODIFIED SLED DREDGE $\ldots \ldots \ldots \ldots \ldots \ldots \ldots \ldots \ldots \ldots \ldots \ldots \ldots$

Kathryn Markey, Whitney Jaillet, Roxanna Smolowitz EVALUATION OF THE QUANTIFICATION OF VIBRIO PARAHAEMOLYTICUS AND VIBRIO VULNIFICUS IN OYSTER HOMOGENATES USING DUPLEX QUANTITATIVE PCR ANALYSIS . .

Kelly N. Markowitz, Jason D. Williams, Maureen K. Krause PREVALENCE, INTENSITY, AND MOLECULAR DETECTION OF THE TREMATODE, PROCTOECES MACULATUS, IN MYTILUS EDULIS

Jesse A. Marks, Robert T. Leaf A SIMULATION MODEL TO EVALUATE THE EFFICIENCY OF

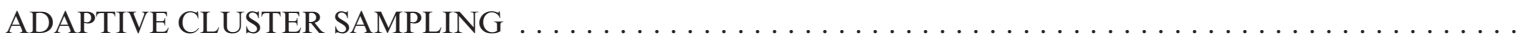

Blythe C. Marshman, James D. Moore, James P. Snider RANGE EXTENSION OF MIKROCYTOS MACKINI, AGENT OF DENMAN ISLAND DISEASE, TO TOMALES BAY, CALIFORNIA, USA

Stephanie Martinez-Rivera, Bradley Stevens REPRODUCTIVE BIOLOGY OF RED DEEP-SEA CRABS (CHACEON QUINQUEDENS)

IN THE MID-ATLANTIC BIGHT

Chris Materna, M. Victoria Agnew, Kathryn Markey, Roxanna Smolowitz

IS THERE A RELATIONSHIP BETWEEN CONDITION INDEX OF THE BLUE MUSSEL, MYTILUS EDULIS, AND LEVEL OF PARASITIC TREMATODAL INFECTION? . .

Joseph L. Matt, Standish K. Allen Jr.

ENVIRONMENTAL EFFECTS ON SEXUAL MATURATION OF TETRAPLOID

C. VIRGINICA UNDER COMMERCIAL HATCHERY CONDITIONS $\ldots \ldots \ldots \ldots \ldots \ldots \ldots$

Leah Maurer, J. Sook Chung THE DENSITY OF FOOD AFFECTS THE NUMBER OF LARVAL STAGES

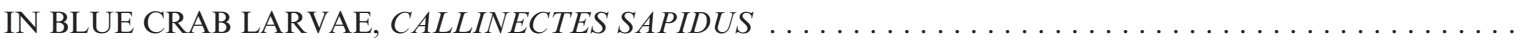

Michael McCann, Dianna Padilla, Sandra Shumway EFFECTS OF A PATCHY FOOD ENVIRONMENT ACROSS LIFE HISTORY STAGES $\ldots \ldots \ldots \ldots \ldots$

Daniel C. McCorkle, Anne L. Cohen, Lisa M. Milke, Barbara Ramon THE EFFECTS OF FOOD SUPPLY AND ELEVATED $\mathrm{PCO}_{2}$ ON THE EARLY DEVELOPMENT OF THE ATLANTIC SURFCLAM (SPISULA SOLIDISSIMA)

P. Sean McDonald, Bridget Ferriss, Jonathan Reum, Christopher Harvey, Glenn VanBlaricom A MODELING APPROACH TO UNDERSTAND THE EFFECTS OF GEODUCK AQUACULTURE ON THE PUGET SOUND FOOD WEB

P. Sean McDonald, Kirstin Holsman, Glenn VanBlaricom CLAMS IN SPACE AND TIME: COMPARING ANALYTICAL METHODS FOR DETERMINING THE EFFECTS OF AQUACULTURE DISTURBANCE $\ldots \ldots \ldots \ldots \ldots \ldots \ldots \ldots \ldots \ldots \ldots$

P. Sean McDonald, Emily Grason, Jeffrey Adams, Kate Litle OF NEEDLES AND HAYSTACKS: HABITAT MAPPING AND CITIZEN SCIENCE TO MONITOR FOR EUROPEAN GREEN CRAB IN WASHINGTON STATE . erine McFarland, Fred Jean, Romain Lavaud, Aswani Volety APPLICATION OF THE DYNAMIC ENERGY BUDGET THEORY TO PERNA VIRIDIS TO MODEL GROWTH AND REPRODUCTION UNDER VARIOUS ENVIRONMENTAL CONDITIONS 
Alexander P. McGeough, Matthew Turner, Maureen K. Krause AGE AND TISSUE-SPECIFIC OCTOPINE DEHYDROGENASE EXPRESSION IN BAY

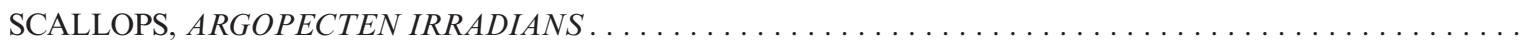

K. A. McGraw, N. Cosentino-Manning COORDINATION, COLLABORATION, AND COOPERATION: PROGRESS IN RESEARCH AND RESTORATION OF THE OLYMPIA OYSTER, OSTREA LURIDA (CARPENTER, 1864) . . . . . . . . .

Erin L. McLean, Brad A. Seibel, C. Tracy Shaw

THE RESPONSE OF MOLTING JUVENILE AMERICAN LOBSTER (HOMARUS

AMERICANUS) TO FUTURE OCEAN ACIDIFICATION PROJECTIONS $\ldots \ldots \ldots \ldots \ldots \ldots \ldots$

Ayana McLeod, Danellie Semple, Margaret A. Carroll, Edward J. Catapane IMMUNOHISTOFLUORESCENCE LOCALIZATION OF HISTAMINE AND HISTAMINE RECEPTORS IN GANGLIA AND TISSUES OF THE EASTERN OYSTER, CRASSOSTREA VIRGINICA . .

Jeffrey Mercer, Dale Leavitt, David Ullman, Candace Oviatt

INVESTIGATING POLLUTED AREAS CLOSED TO SHELLFISHING AS POTENTIAL

LARVAL SOURCES FOR FISHED POPULATIONS OF NORTHERN QUAHOGS IN

NARRAGANSETT BAY, RHODE ISLAND . . . . . . . . . . . . . . . . . . .

Jeffrey Mercer, Dale Leavitt, Azure Cygler, Monique LaFrance, Dave Beutel, Jennifer McCann DEVELOPMENT OF THE RHODE ISLAND STATE SHELLFISH MANAGEMENT PLAN AND STEPS TOWARD IMPLEMENTING RECOMMENDATIONS $\ldots \ldots \ldots \ldots \ldots \ldots \ldots \ldots$

Cale Miller, George Waldbusser EFFECTS OF DIURNAL VARIATION IN MARINE SEDIMENT CORROSIVITY ON THE NORTHERN QUAHOG (= HARD CLAM)(MERCENARIA MERCENARIA): A STAGE-BASED POPULATION MODEL

Fabienne Mondelus, Beatrix Boisette, Fiana Bess, Edward J. Catapane, Margaret A. Carroll WESTERN BLOT IDENTIFICATION OF DOPAMINE AND GABA RECEPTORS IN GILL OF THE EASTERN OYSTER, CRASSOSTREA VIRGINICA

Joshua Moody, Danielle Kreeger, Elizabeth Watson GEOSPATIAL VARIATION OF RIBBED MUSSEL (GEUKENSIA DEMISSA) ECOSYSTEM SERVICES ACROSS THE SALT MARSH LANDSCAPE $\ldots \ldots \ldots \ldots \ldots \ldots \ldots \ldots \ldots \ldots \ldots \ldots$

James Moore, Shauna Byron, Blythe Marshman, James Snider AN OXYTETRACYCLINE BATH SERIES ELIMINATES THE AGENT OF WITHERING SYNDROME, CANDIDATUS XENOHALIOTIS CALIFORNIENSIS, IN CAPTIVE ABALONE POPULATIONS . .

D. Nathaniel Mulcahy

IS IT POSSIBLE TO ESTABLISH A SUSTAINABLE FISHERY PROGRAM IN MASSACHUSETTS

FOR RAZOR CLAMS, ENSIS DIRECTUS?

Adrian Munguia-Vega, Ignacio Leyva-Valencia, Daniel B. Lluch-Cota, Pedro Cruz-Hernandez.

LARVAL DISPERSAL OF PANOPEA GLOBOSA FOLLOWS CLOCKWISE CURRENTS IN

THE NORTHERN GULF OF CALIFORNIA . .

Daphne Munroe, Zhiren Wang, Dvora Hart, Burton Shank, Dale Haidvogel, Eric Powell, John Klinck, Eileen Hofmann MANAGING THE SUPPLY SIDE: LARVAL DISPERSAL FROM ROTATING CLOSURES IN THE ATLANTIC SEA SCALLOP (PLACOPECTEN MAGELLANICUS) FISHERY . . . . . . . . . . . . .

Daphne Munroe, Eleanor Bochenek, Burton Shank, Dvora Hart, Sarah Borsetti,

Collin Dobson, Sean Martin, Joseph Cracappa SPATIAL PATTERNS IN PHENOTYPE AND ABUNDANCE OF OFFSHORE WHELK (BUCCINUM UNDATUM) IN THE MID-ATLANTIC REGION 
Gabriela Navas

MORPHOLOGY AND AGE DIFFERENTIATION IN THE PACIFIC GEODUCK, PANOPEA

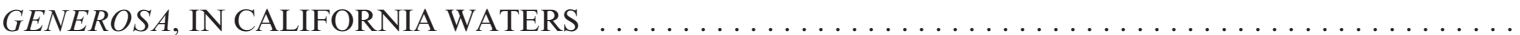

Melissa Neuman, David Witting, Susan Wang, Kevin Stierhoff, John Hyde A COLLABORATIVE AND ADAPTIVE STRATEGY FOR REBUILDING WHITE ABALONE POPULATIONS IN SOUTHERN CALIFORNIA $\ldots \ldots \ldots \ldots \ldots \ldots \ldots \ldots \ldots \ldots \ldots \ldots \ldots$

Laura A. Newcomb, Ian Jefferds, Emily Carrington

MEASURING RISK: UNCOVERING THE ROLE OF WATER TEMPERATURE AND pH ON SEASONAL

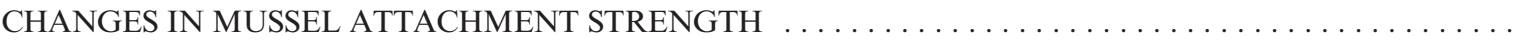

Tammy Norgard, Graham Gillespie, Sean MacConnachie, Jessica Finney

OLYMPIA OYSTER POPULATIONS AT THIRTEEN LOCATIONS ACROSS BRITISH COLUMBIA .......

Mark S. Oates, Craig M. Young

OBSERVATIONS OF GONAD STRUCTURE AND GAMETOGENIC TIMING IN A

RECOVERING POPULATION OF OSTREA LURIDA (CARPENTER, 1864)

Thomas Parker, Rick Torres, Jennifer Burnaford, Danielle Zacherl

RECRUITMENT, SURVIVAL, AND GROWTH OF THE OLYMPIA OYSTER (OSTREA LURIDA)

AND THE JAPANESE OYSTER (CRASSOSTREA GIGAS) AS A FUNCTION OF TIDAL HEIGHT ......

Jenny Paterno, David Bushek, Lisa Calvo

FAUNAL COMMUNITY USE OF ENHANCED AND NATURAL OYSTER REEFS IN DELAWARE BAY .

Kennedy Paynter, Anne Handschy, Adriane Michaelis, Hillary Lane

OYSTER REEF RESTORATION IN HARRIS CREEK, MARYLAND: POPULATION

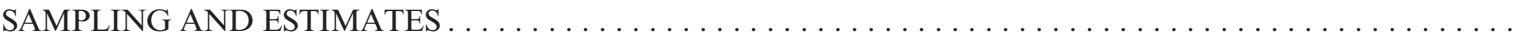

Betsy Peabody

WASHINGTON SHELLFISH INITIATIVE SPAWNS OLYMPIA OYSTER HATCHERY $\ldots \ldots \ldots \ldots$

Sarah Pease, Wolfgang Vogelbein, Kimberly Reece

ASSESSING RISK ASSOCIATED WITH THE HARMFUL ALGAL BLOOM SPECIES

ALEXANDRIUM MONILATUM TO THE VIRGINIA OYSTER INDUSTRY

668

668

668

. Petersen, Camille Saurel, Paula Canal-Vergés

EXTRACTIVE CULTURES AS A TOOL FOR MITIGATION OF EXCESS NUTRIENT

RUN-OFF FROM LAND .

Maria Prado-Alvarez, Grainne Darmody, Steve Hutton, Amy ÓReilly, Sharon Lynch, Sarah C. Culloty

OSTREID HERPES VIRUS (OSHV-1 $\mu$ VAR) DETECTION IN THE IRISH COAST DURING A

VERY WARM SUMMER

Maria Prado-Alvarez, Jens Carlsson, Sarah C. Culloty

EXPERIMENTAL INFECTION OF CRASSOSTREA GIGAS SPAT AND LARVAE WITH

DIFFERENT SUSCEPTIBILITY TO O $\mathrm{SHV}-1 \mu \mathrm{VAR}$

Eman Radwan, Gaber Saad

ECOLOGICAL EFFECTS ON THE SCANNING AND TRANSMISSION ELECTRON

MICROSCOPE OF THE FOOT AND SHELL IN THE OYSTER, PINCTADA RADIATA

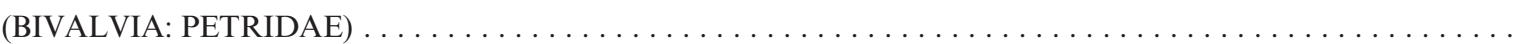

Raymond RaLonde

AN ALASKA SEA GRANT, SHELLFISH FARMING INDUSTRY, AND ALASKA STATE

GOVERNMENT PARTNERSHIP TO GROW A SHELLFISH AQUACULTURE IN ALASKA . . . . . . . . . .

Jonathan Reum, Bridget Ferriss, P. Sean McDonald, Chris Harvey

USING QUALITATIVE MODELS TO EVALUATE ENVIRONMENT-AQUACULTURE

LINKAGES IN THE SOUTH PUGET SOUND AND WILLAPA BAY FOOD WEBS

David Witting, Tom Ford, Susan Wang, Melissa Neuman, Ariadne Reynolds SPAWNING AND OUTPLANTING TECHNIQUE DEVELOPMENT FOR GREEN ABALONE

(HALIOTIS FULGENS) RESTORATION IN SOUTHERN CALIFORNIA 
Gaëlle Richard, Philippe Miner, Nelly Le Goic, Adeline Bidault, Virgile Quillien, Charlotte Corporeau,

Fabrice Pernet, Christophe Lambert, Pierre Boudry, Christine Paillard, Fabienne Guérard

INFLUENCE OF DIET AND SEX ON HOST-PATHOGEN RELATIONSHIP: THE CASE

OF THE MANILA CLAM (RUDITAPES PHILIPPINARUM) AND ITS PATHOGEN VIBRIO TAPETIS . . . .

Kate Ritter, Standish Allen

PILOT STUDY OF FAMILY-BASED BREEDING OF TETRAPLOID C. VIRGINICA . . . . . . . . . . . .

Shawn Robinson, Keng Pee Ang, Alejandro Buschmann, Thierry Chopin, Bruce MacDonald, Gregor Reid GAZING INTO THE CRYSTAL BALL FOR AQUACULTURE DEVELOPMENT: WHAT IS IN THE GLOBAL FUTURE FOR INTEGRATED MULTI-TROPHIC AQUACULTURE (IMTA)?

Rachel Rodriguez, Sean Powers, Andrew Whelton, Julia Edelbrock, Scott Rikard, Anne Boettcher IMPACT OF COREXIT 9500 ON THE EARLY LIFE STAGES OF THE EASTERN OYSTER, CRASSOSTREA VIRGINICA

Arlenie Rogers WHEN A NEW FISHERY IS CREATED: THE BELIZE SEA CUCUMBER EXPERIENCE . . . . . . . . . .

Laura Rogers-Bennett, Cynthia Catton, Christy Juhasz, David Kushner SEARCHING FOR A STOCK RECRUITMENT RELATIONSHIP FOR RED

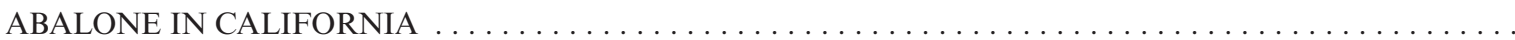

Maria Rosa, J. Evan Ward, Bridget A. Holohan, Sandra E. Shumway, Gary H. Wikfors,

Emmanuelle Pales Espinosa, Bassem Allam QUANTIFYING SURFACE-PROPERTY PROFILES OF MICROALGAE TO DEVELOP PARTICLE-SELECTION MODELS FOR BIVALVES $\ldots \ldots \ldots \ldots \ldots \ldots \ldots \ldots$

Michael Rubino, Susan Bunsick, Summer Morlock, Robert Jones, Kay McGraw THE NOAA NATIONAL SHELLFISH INITIATIVE: BUILDING PARTNERSHIPS TO MAXIMIZE THE ECOLOGICAL AND ECONOMIC BENEFITS OF SHELLFISH . .

David Rudders, John Ward A MULTI-DISCIPLINARY DERIVATION AND ESTIMATION OF A SEA SCALLOP

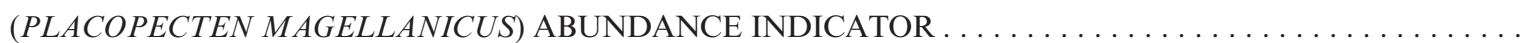

John Scarpa BACTERIAL CHALLENGE OF NORTHERN QUAHOG (= HARD CLAM), MERCENARIA MERCENARIA, WITH PUTATIVELY DIFFERENT COGNATE HEAT SHOCK PROTEIN LEVELS . . . . .

John Scarpa, Paul S. Wills, Christopher Robinson, Madelyn E. Russell OPTIMIZING MICROALGAL CULTURE FOR A LAND-BASED RECIRCULATING INTEGRATED MULTI-TROPHIC AQUACULTURE SYSTEM $\ldots \ldots \ldots \ldots \ldots \ldots \ldots \ldots \ldots \ldots$

William Schroer, Tal Ben-Horin, Gorka Bidegain, Lauren Huey, Joseph P. Looney,

Eric N. Powell, Daphne Munroe, David Bushek DILUTION OF THE OYSTER PARASITE, PERKINSUS MARINUS, BY COMMENSAL TUNICATES

Muki Shpigel

INTEGRATED MULTI-TROPHIC MARICULTURE SYSTEMS: AN ECOLOGICAL APPROACH FOR A SUSTAINABLE AQUACULTURE, BENEFITS, AND CONSTRAINTS ..........

Muki Shpigel, David Ben-Ezra, Vladimir Odnietzov, Lilach Shauli PERFORMANCE OF THE EUROPEAN SEA URCHIN, PARACENTROTUS LIVIDUS,

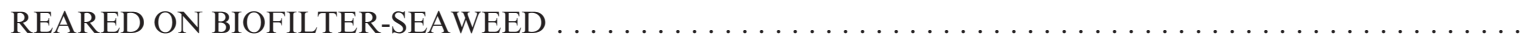

Sten Siikavuopio, Philip James EFFECTS OF TEMPERATURE ON FEED INTAKE, GROWTH, OXYGEN CONSUMPTION, AND TEMPERATURE PREFERENCE IN RED KING CRAB

Sten Siikavuopio, Philip James, Bjor Steinar Sither LONG-TERM GROWTH STUDY OF MALE AND FEMALE GREEN SEA URCHIN, STRONGYLOCENTROTUS DROEBACHIENSIS, UNDER CONSTANT LIGHT AND TEMPERATURE REGIME 
Katherine Silliman, Danielle Zacherl, Ryan Walter

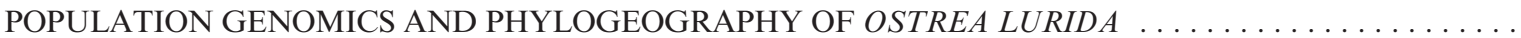

Julian Sison, Beatriz, Orihuela, Daniel Rittschof, Gary H. Dickinson CHARACTERIZING KEY PROTEINS THAT CONTRIBUTE TO BARNACLE ADHESION ...........

Leah Sloan, Sarah Hardy ZOMBIE KING CRABS: THE EFFECTS OF TEMPERATURE AND SALINITY ON LARVAL

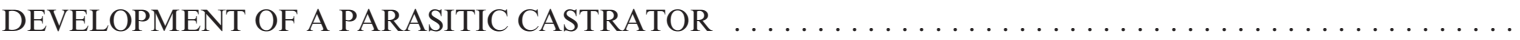

Ashley R. Smyth, Annie E. Murphy, Karen Hudson, Bongkeun Song, Iris C. Anderson EXAMINING WATER QUALITY BENEFITS OF OYSTER AQUACULTURE . . . . . . . . . . . .

Saebom Sohn, Wenjing Zhao, David Nelson, David Rowley, Roxanna Smolowitz, Marta Gómez-Chiarri PROBIOTICS FOR SHELLFISH HATCHERIES: FROM MECHANISMS OF ACTION TO HATCHERY TRIALS

Melissa Southworth, John Thomas, Roger Mann TOWARDS THE PAPERLESS OYSTER SURVEY: CONSIDERATION OF DIGITAL

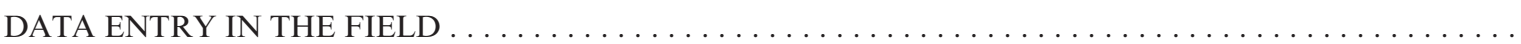

Brad Stevens, Bhae-Jin Peemoeller GROWTH OF THE CHANNELED WHELK, BUSYCOTYPUS CANALICULATUS, IN BUZZARDS BAY, MASSACHUSETTS OVER ONE OR TWO YEARS AT LIBERTY $\ldots \ldots \ldots \ldots \ldots \ldots \ldots$

Bethany Stevick, Bob Sizemore INVESTIGATING REGIONAL DIFFERENCES IN GROWTH AND NATURAL MORTALITY RATES OF THE PACIFIC GEODUCK, PANOPEA GENEROSA, IN WASHINGTON STATE USA, FOR MANAGEMENT OF THE COMMERCIAL WILDSTOCK FISHERY

Eric R. Stewart, William C. Walton

A COMPARATIVE STUDY OF HABITAT VALUE FOR THE JUVENILE BLUE CRAB (CALLINECTES SAPIDUS) PROVIDED BY OFF-BOTTOM OYSTER FARMING IN THE NORTHERN GULF OF MEXICO

Kevin D. E. Stokesbury, N. David Bethoney, Jonathan D. Carey, Bradley P. Harris PATTERNS IN EPIBENTHIC COMMUNITIES EXPOSED TO VARYING LEVELS OF FISHING PRESSURE ON GEORGES BANK, USA.

Benjamin Stone, Nancy Hadley, Denise Sanger, Amanda Fornal, Dianne Greenfield, Peter Kingsley-Smith LARGE-SCALE COMMERCIAL TRIPLOID OYSTER (CRASSOSTREA VIRGINICA) AQUACULTURE IN SOUTH CAROLINA, USA: CONCERNS, CHALLENGES, AND OPPORTUNITIES ...

Matthew Stone, Gulnihal Ozbay, Venugopal Kalavacharla STABLE ISOTOPE ANALYSIS OF BLUE CRABS RELATIVE TO WATER QUALITY IN BLACKBIRD CREEK, DELAWARE

Matthew Stone, Gulnihal Ozbay, Venugopal Kalavacharla ENVIRONMENTAL FACTORS INFLUENCING POPULATION DYNAMICS OF THE BLUE CRAB (CALLINECTES SAPIDUS) IN A LARGE TIDAL CREEK NEAR THE DELAWARE BAY AND POSSIBLE IMPLICATIONS TO STABLE ISOTOPE ANALYSIS $\ldots \ldots \ldots \ldots \ldots \ldots \ldots \ldots$

Leslie Sturmer, William White, Todd Osborne, Rex Ellis ADVANCEMENT OF SUNRAY VENUS CLAM, MACROCALLISTA NIMBOSA, AQUACULTURE IN FLORIDA THROUGH EVALUATION OF ALTERNATIVE

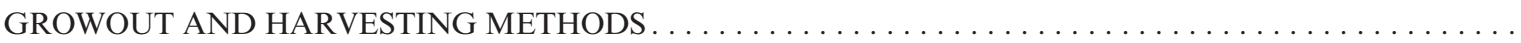

Cailan S. Sugano, Daniel C. McCorkle, Anne L. Cohen, Lisa M. Milke THE EFFECTS OF FOOD SUPPLY AND ELEVATED $P \mathrm{CO}_{2}$ ON THE EARLY DEVELOPMENT OF THE BAY SCALLOP $($ ARGOPECTEN IRRADIANS) $\ldots \ldots \ldots \ldots \ldots \ldots$

Katherine M. Swiney, W. Christopher Long, Robert J. Foy OCEAN ACIDIFICATION ALTERS EMBRYONIC DEVELOPMENT AND REDUCES THE NUMBER OF VIABLE LARVAE HATCHED AND CALCIFICATION IN SOUTHERN TANNER CRAB, CHIONOECETES BAIRDI 
Mitchell Tarnowski

NATURAL RECOVERY OF AN EASTERN OYSTER POPULATION FROM A CATASTROPHIC

EVENT AND ITS IMPLICATIONS FOR RESTORATION PLANNING $\ldots \ldots \ldots \ldots \ldots \ldots \ldots \ldots \ldots$

Rick Torres, Thomas Parker, Jennifer Burnaford, Danielle Zacherl

RECRUITMENT, SURVIVAL, AND GROWTH OF THE OLYMPIA OYSTER (OSTREA LURIDA) AND THE JAPANESE OYSTER (CRASSOSTREA GIGAS) AS A FUNCTION OF TIDAL HEIGHT . . . . . . . . . . .

Ditte Torring, Per Andersen, Per Dolmer, Jonathan Carl, Christina Soegren, Mathilde Pedersen PREDATION FROM BOTH STARFISH (ASTERIAS RUBENS) AND EIDERS (SOMATERIA MOLLISSIMA) ON SUSPENDED MUSSELS (MYTILUS EDULIS) IN AN INTEGRATED

MARICULTURE PRODUCTION IN INNER DANISH WATERS $\ldots \ldots \ldots \ldots \ldots \ldots \ldots \ldots \ldots$

Howard Townsend, David Bruce, Philip Klavon, Jay Lazar, Giselle Samonte, Andrew Turner ASSESSING THE BENEFITS OF OYSTER REEF RESTORATION IN THE CHESAPEAKE BAY . . . . . . . .

Brendan Turley, Jackie Shannon, Thomas Leggett, Jan McDowell, Kimberly Reece GENETIC CONNECTIVITY OF CRASSOSTREA VIRGINICA: THE INFLUENCE OF HYDRODYNAMICS ON THE POPULATION GENETICS OF A RESTORATION PROJECT IN THE LAFAYETTE RIVER, VIRGINIA $\ldots \ldots \ldots \ldots \ldots \ldots \ldots \ldots \ldots \ldots \ldots \ldots$

Brent Vadopalas, Molly Jackson, Jonathan P. Davis INDUCTION OF TRIPLOIDY IN THE PURPLE-HINGED ROCK SCALLOP, CRASSADOMA

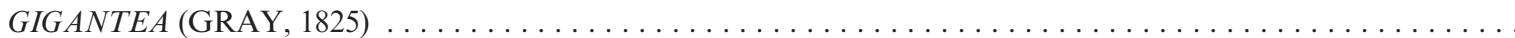

Glenn R. VanBlaricom, Melissa J. Neuman, David A. Witting INDICATIONS OF RECOVERY TRENDS IN THREE SPECIES OF ABALONE IN CALIFORNIA, WITH APPARENT LINKAGES TO OCEAN-SCALE TEMPERATURE ANOMALIES ......

Pandora Wadsworth, Scott Rutherford, Dale Leavitt, David Ullman USING SUBSURFACE DRIFTERS TO TRACK NORTHERN QUAHOG MERCENARIA MERCENARIA, LARVAL DISTRIBUTION PATTERNS IN NARRAGANSETT BAY . . .

George G. Waldbusser, Burke Hales, Matthew Gray, Chris J. Langdon, Brian Haley, Elizabeth Brunner,

Cale Miller, Iria Gimenez, Greg Hutchinson FAST SHELLS AND SLOW SHELLS: OCEAN ACIDIFICATION AND SEASHELLS IN BIVALVE LARVAE

Benjamin Walker, Cynthia Catton, Laura Rogers-Bennett CRITICAL TEMPERATURE THRESHOLDS CAN BE USED TO SELECT OPTIMAL

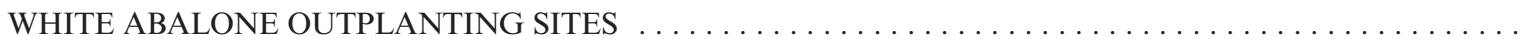

William Walton, Eric Stewart EFFECTS OF STOCKING DENSITY IN THE NURSERY AND THE FIELD ON EASTERN OYSTER, CRASSOSTREA VIRGINICA, GROWTH, AND SHAPE

William C. Walton, Chris Nelson, Alfred Sunseri, LaDon Swann THE GULF SHELLFISH INITIATIVE: A REGIONAL CHALLENGE AND OPPORTUNITY

Susan Wang, Melissa Neuman, Shallin Busch, Carolyn Friedman, Kristen Gruenthal, Rick Gustafson,

David Kushner, Kevin Stierhoff, Glenn VanBlaricom, Sadie Wright DECISION-MAKING IN THE FACE OF UNCERTAINTY: AN EVALUATION OF PINTO ABALONE UNDER THE ENDANGERED SPECIES ACT $\ldots \ldots \ldots \ldots \ldots \ldots \ldots \ldots \ldots \ldots \ldots$

Kerstin Wasson, Andy Chang, Anna Deck, Paul Dinnel, Sarah Dudas, Matt Ferner, Ted Grosholz,

Jennifer Ruesink, Alan Trimble, Dick Vander Schaaf, Chela Zabin, Danielle Zacherl VARIANCE IN RECRUITMENT OF OLYMPIA OYSTERS ACROSS WEST COAST ESTUARIES ........

Thomas Webler, Seth Tuler, Jessica Whitehead, Esperanza Stancioff, Elizabeth Fly, Brian Seitzman, Julie Davis USING PARTICIPATORY MODELLING TO HELP SEAFOOD PRODUCERS ON THE UNITED STATES EAST COAST IDENTIFY WAYS TO ADAPT TO A CHANGING CLIMATE . . . . . . . . rine Wellman THE ECOSYSTEM SERVICE VALUE OF NITROGEN REMOVAL THROUGH BIOEXTRACTION IN LONG ISLAND SOUND 
Amanda A. Wenczel, David Bushek

FEEDING INTERACTIONS OF COHABITING BIVALVE MOLLUSCS: A STUDY OF

INTERSPECIFIC RELATIONSHIPS AND THEIR POTENTIAL EFFECTS ON THE FUTURE

OF SHELLFISH AQUACULTURE AND RESTORATION $\ldots \ldots \ldots \ldots \ldots \ldots \ldots \ldots \ldots \ldots \ldots \ldots$

Stephanie Reynolds Westby, David Bruce, Kimberly Gross, Jay Lazar, Kara Muzia, Ken Paynter, Angela Sowers,

Ward Slacum, Howard Townsend, Eric Weissberger

LARGE-SCALE OYSTER RESTORATION IN CHESAPEAKE BAY $\ldots \ldots \ldots \ldots \ldots \ldots \ldots \ldots$

Justin L. Wilson, Bradley G. Stevens

AGE DETERMINATION OF RED DEEP-SEA CRAB (CHACEON QUINQUEDENS) BY

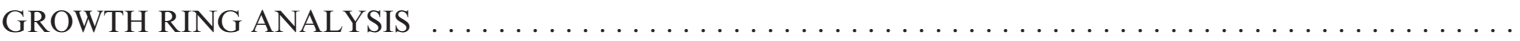

Diane Windham

AN OVERVIEW OF CALIFORNIA SHELLFISH ACTIVITIES $\ldots \ldots \ldots \ldots \ldots \ldots \ldots \ldots \ldots$

Brittany Wolfe, Stan Allen

COMPARATIVE LARVAL PERFORMANCE BETWEEN TETRAPLOID X TETRAPLOID

AND TETRAPLOID X DIPLOID CONSTRUCTS USING MOSAIC AND NON-MOSAIC

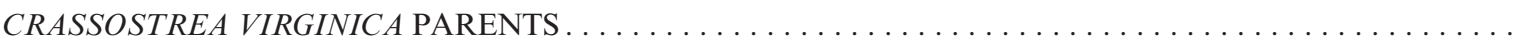

Qinggang Xue, Jean-Philippe Béguel, Jerome La Peyre

CVSI FAMILY OF PROTEASE INHIBITORS IS HIGHLY DIVERSE AND LIKELY EVOLVES

ACTIVELY IN MOLLUSCS .

Hanhan Yao, Yinghui Dong, Zhihua Lin

CLONING, IDENTIFICATION, AND EXPRESSION OF THE LAP3 GENE IN THE

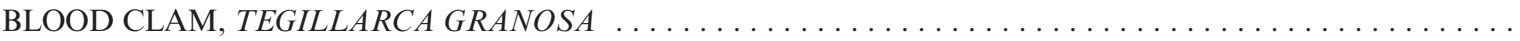

Aparna Yarram, William D. Coffey, Brian Matoke, W. Christopher Long, Katherine Swiney,

Robert Foy, Gary H. Dickinson

OCEAN ACIDIFICATION LEADS TO ALTERED MICROMECHANICAL PROPERTIES OF

THE MINERALIZED CUTICLE OF JUVENILE RED AND BLUE KING CRABS

Xiaoshen Yin, Dennis Hedgecock

IMPROVED ANALYSIS OF CROSSBREEDING TRIALS TO INCREASE THE YIELD OF

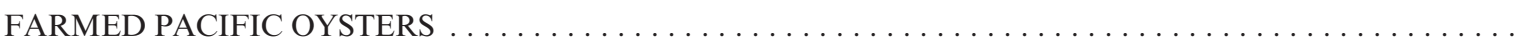

Weiwei You, Xuan Luo, Caihuan Ke

INTRASPECIES AND INTERSPECIES ABALONE HYBRIDIZATION PRACTICES IN

SOUTHERN CHINA: FROM LABORATORY TO INDUSTRY $\ldots \ldots \ldots \ldots \ldots \ldots \ldots \ldots \ldots \ldots$

Chela Zabin, Kerstin Wasson, Susanne Fork

RESTORATION OF NATIVE OYSTERS IN A HIGHLY INVADED ESTUARY $\ldots \ldots \ldots \ldots \ldots \ldots$

Danielle Zacherl, Shannon Crossen, Cristina Fuentes, Andrea Moreno, Thomas Parker

RESTORATION OF OLYMPIA OYSTERS, OSTREA LURIDA, IN SOUTHERN CALIFORNIA 
THE USE OF FRESH TISSUE BIOPSY ANALYSIS TO EVALUATE TREMATODE PREVALENCE IN THE GONADS OF THE BLUE MUSSEL, MYTILUS EDULIS

M. Victoria Agnew, Chris Materna, Kathryn Markey, Roxanna Smolowitz

Roger Williams University, 1 Old Ferry Road, Bristol, RI, 02809, USA

Digenetic trematodes, especially Proctoeces maculates, are known to infect the blue mussels, Mytilus edulis, in Rhode Island. There is little information on the effect that these pathogens have on the overall health of the blue mussel, but it is hypothesized that mussel mortality events may be related to severe infections. To address this uncertainty, animals from five different locations in Narragansett Bay, RI were collected with three different size classes ( $<30 \mathrm{~mm}, 30-45 \mathrm{~mm}$, and $>45 \mathrm{~mm}$ ) at several time periods from spring to fall, and were analyzed for condition index and histopathology. Additionally, using mantle biopsies, animals in the size class larger than $45 \mathrm{~mm}$ were examined for prevalence and abundance of trematodes. The mantle tissue that contains mussel gonadal material was biopsied and used to generate squash preparations that were surveyed microscopically for levels of trematode infection and parasite morphology. The infection was rated on a scale of zero to four, and photos of each level of infection were archived for further analysis. The animals were also grossly assessed for the color of their mantle and designated as female, male, or ambiguous. Sex verification was then made by observation of gonadal material seen microscopically. Data from all sites correlating the sex of the animals, trematode prevalence and intensity, and parasite forms identified in the mussel tissues will be presented.

EFFECT OF TIDE AND PHOTOPERIOD ON ABUNDANCE AND DISTRIBUTION OF LARVAE OF QUEEN CONCH, STROMBUS GIGAS

Dalila Aldana Aranda ${ }^{1}$, Martha Enríquez Díaz ${ }^{1}$, Claire ParisLimouzy $^{2}$

${ }^{1}$ Laboratorio de Conservación, Cultivo y Biología de Moluscos, Centro de Investigación y de Estudios Avanzados del Instituto Politécnico Nacional, Unidad Mérida, Carretera Antigua a Progreso, Km. 6, A.P. 73 Cordemex, C.P. 97310, Mérida, Yucatán, México

${ }^{2}$ Applied Marine Physics, Rosenstiel School of Marine and Atmospheric Science, University of Miami, 4600 Rickenbacker Causeway, Miami, FL, 33149, USA

Larval abundance and distribution of queen conch, Strombus gigas, is regulated by currents (Jesus Navarrete, 1999), temperature (Stoner et al., 1992), photoperiod (Barile et al., 1994) and depth (Stoner \& Davis, 1997). Daigle et al. (2014) studied the effect of tides on abundance of gastropods larvae. The goals of this study were to determine the effects of tides and photoperiods on vertical abundance of queen conch larvae. We carried out plankton tows at Puerto Morelos, Quintana Roo, Mexico (2054'34" N-86 50'13" W) in June 2014. Plankton samples were made at surface and -3.0 $m$ covering two high and two low tides per day $(n=40)$. The highest abundance of larvae was recorded during a Full moon with $0.72 \pm 0.66$ larvae. $10 \mathrm{~m}^{-3}$, and at high tide $\left(0.87 \pm 0.62\right.$ larvae $\left.\cdot 10 \mathrm{~m}^{-3}\right)$. Significant variation was recorded between abundance of larvae and depth, tidal coefficient and moon phases $(\mathrm{p}=0.0034, \mathrm{p}=$ 0.0015 , and $p \leq 0.0001$, respectively). The highest abundances of larvae were recorded during the full moon, at high tide near the surface $\left(1.16 \pm 0.80\right.$ larvae. $\left.10 \mathrm{~m}^{-3}\right)$. Regardless of the value of the coefficients of tide, larval abundance was more homogeneous at 3 $m$ depth. On the surface, larval density showed variations; being greater at higher tidal coefficient. With respect to photoperiod, samples taken during the day had higher larval abundance as those conducted at night. Significant variation was recorded between abundance of larvae and depth and tidal coefficients $(\mathrm{p}=0.0034$, $\mathrm{p}=0.0015$, respectively), indicative of tidal stream transport.

\section{TOWARDS A FUNCTIONAL CHARACTERIZATION OF EXTRAPALLIAL HEMOCYTES IN BIVALVES \\ Bassem Allam, Emmanuelle Pales Espinosa}

School of Marine and Atmospheric Sciences, Stony Brook University, Stony Brook, NY, 11794, USA

In bivalves, the extrapallial space is located between the external epithelium of the mantle and the inner face of the shell. Since our initial description of the presence of abundant hemocytes and humoral factors in the extrapallial fluid nearly two decades ago, a growing body of evidence converged towards highlighting a prime role of extrapallial hemocytes in processes ranging from shell crystal formation and deposition to immune defense. Extrapallial hemocytes were shown to display basic antimicrobial activities including phagocytosis of non-self material and production of a wide range of antimicrobial compounds. The activity of extrapallial hemocytes was also shown to display a dynamic response to microbial infection. Similarly, significant regulation in hemocyte counts and activities were noted in response to biotically- and abiotically-inflicted shell damage. Our latest findings suggest that extrapallial hemocytes may function as sentinel peripheral cells that interact with microbes that venture into this confined space. Overall, research has demonstrated important similarities and differences between extrapallial hemocytes and circulating hemocytes. Despite this (rather fragmentary) evidence, a systematic (and comparative) functional characterization of extrapallial hemocytes is lacking. The talk will give an overview of the research activities planned or underway to fill this knowledge gap. 
THE MULTIPLE, CENTRAL ROLES OF MUCOSAL SECRETIONS IN MARINE BIVALVES

Bassem Allam, Emmanuelle Pales Espinosa

School of Marine and Atmospheric Sciences, Stony Brook University, Stony Brook, NY, 11794, USA

Mucosal tissues represent the major interface for exchange between animals and their environment. Mucus is produced from virtually all molluscan epithelia and plays a role in several biological functions such as locomotion and navigation, freeze protection, attachment, and defense against predators. In filter-feeding bivalves, copious amounts of mucus are produced by pallial organs (gills, mantle, palps) to help process waterborne microbes. This presentation will summarize our findings on the role of pallial mucus in interactions with waterborne microbes in the framework of predatorprey and host-pathogen associations. Our results showed the presence in pallial mucus of lectins that bind glycans associated with the cell surface of microalgae allowing selective processing and mediating the sorting of food particles in suspension-feeding bivalves. In parallel, we demonstrated that mucus factors can serve as triggers for the activation of adapted microbes to initiate host colonization and invasion. For example, significant regulation of the proliferation and virulence was recorded in the alveolate parasite Perkinsus marinus following exposure to oyster mucus. While the pallial mucus of the susceptible oysters (Crassostrea virginica) enhanced the growth and the virulence of the parasite, mucus from resistant oysters (C. gigas) was strongly inhibitory suggesting that $P$. marinus host specificity may begin in the mucus. Evidence also suggests a dynamic regulation of mucus factors in response to intrinsic and extrinsic triggers. This context raises fascinating questions around hostmicrobe crosstalk and feedback controls of these interactions and calls for appealing inquisitive research in the years to come.

OLYMPIA OYSTER CULTIVATION FOR RESTORATION PART 2: POST-HATCHERY PRACTICES AND OUTPLANT CONSIDERATIONS

\section{Brian Allen, Ryan Crim, Betsy Peabody}

Puget Sound Restoration Fund, 382 Wyatt Way Northeast, Bainbridge Island, WA, 98110 , USA

Stock enhancement was initially (2002) the only practice employed to restore Olympia oyster populations in Puget Sound. The practice was suspended in 2004 over concerns about oyster genetics and on the advice of our restoration partners in Washington State. The recent gains in our understanding of stock structure and population genetics for this oyster have allowed hatchery cultivation to again emerge as a useful tool for oyster bed habitat restoration in Puget Sound. This presentation will springboard from Part 1 on the cultivation process at the Ken Chew Center for Shellfish Research and Restoration and discuss the adaptation of hatchery production, post-hatchery husbandry for Olympia oysters, how these products are used in restoration projects and considerations for outplants.
THE SEA GARDENS OF DENMARK - A NEW CONCEPT BASED ON RECREATIONAL AQUACULTURE ACTIVITIES IN LOCAL DANISH MARINE AND ESTUARINE WATERS Per Andersen, Ditte Tørring, Per Dolmer, Jonathan Carl

Orbicon, Dept. of Water and Nature Resources, Jens Juulsvej 16, 8260 Viby Denmark

Sea garden projects (cooperatives) make it possible for people in local communities to develop their own small-scale aquaculture production of shellfish and seaweed in small marine gardens close to their "back yard."High quality, environmentally friendly shellfish and seaweed products can be produced and consumed by the members of the association themselves, or they can be used as the basis for development and sale of locally produced "marine" products. Sea garden projects provide the basic set-up for small-scale aquaculture production, often in the form of long-line rope structures, well known from production of mussels and seaweed. Members of a sea-garden cooperative are allowed to use a pre-determined length of the long-line for their own production. Sea gardens are based on local participation, commitment and voluntary work, while strengthening the local community and improving environmental quality (removal of nutrients and plankton algae in the form of shellfish and seaweed biomass) in our coastal areas. Key goals or visions of sea gardens are to develop small-scale production of marine products while promoting recreational activities and environmental awareness.

\section{OLYMPIA OYSTER (OSTREA LURIDA) RECRUITMENT WITHIN PUGET SOUND ENHANCEMENT PROJECT SITES: SUBSTRATE AND DENSITY CORRELATIONS TO JUVENILE RECRUITMENT}

Brian Allen, Jonathan Davis

Puget Sound Restoration Fund, 382 Wyatt Way Northeast, Bainbridge Island, WA, 98110, USA

Shell habitat enrichment (cultching) is currently employed in Puget Sound as an effective means of stock enhancement for priority restoration sites that are structure-limited. These project sites rely on natural settlement, direct enhancement or both to complete the stock rebuilding goals. The development of robust local stocks is the means to a biogenic habitat end; the habitat of interest here is Olympia oyster bed, which is modulated by the structure of the local populations. Observed correlations between emergent substrate (cultch) amount and oyster density are illuminating, allowing the adaptation our shell application practice in the light of limited and expensive shell resources. Oyster density, abundance and proximity to and within project sites have also shown a significant correlation to recruitment magnitude. We suggest that the juvenile density (Young of the Year) metric is the most relevant to stock enhancement and persistence in project sites. This presentation will present new data and discuss the functional correlations between settlement substrate amount, adult oyster density and juvenile recruitment at restoration project sites in Puget Sound. 
DEVELOPMENT OF A FINANCIAL RISK ANALYSIS TOOL FOR FLORIDA HARD CLAM GROWERS Thomas Anderson ${ }^{1}$, Chuck Adams ${ }^{1}$, Leslie Sturmer ${ }^{2}$

${ }^{1}$ Food and Resource Economics Department, University of Florida, P.O. Box 110240, Gainesville, FL, 32653, USA

${ }^{2}$ Cooperative Extension, Institute of Food and Agricultural Sciences, University of Florida, P.O. Box 89, Cedar Key, FL, 32625, USA

To rural communities along the Florida Gulf Coast, the burgeoning shellfish culture industry has grown to be an important part of the local economy. Warm water estuaries and miles of undeveloped shoreline provide an ideal habitat for year-round culture of hard clams, Mercenaria mercenaria. In order to facilitate the development of this industry, a multiyear budgeting tool was developed to model the operations of an existing one acre farm. Upon entering the financial and production characteristics of their operation, users are provided with a five year projection of cash flow, an average budget, and a sensitivity analysis of major inputs. With further development, this model can be expanded to provide a more robust risk analysis to account for fluctuations in price, environmental conditions, and the risk of catastrophic events such as hurricanes. Perhaps this tool can one day be used by farmers to provide a framework for modeling their operations.

INTEGRATED MARINE ALGAE AND CRASSOSTREA VIRGINICA LARVAL REARING COMPARING LIVE AND CONCENTRATED DIET BLENDS OF THE SAME GENUS Christopher Andrikos

Auburn University Shellfish Laboratory, 150 Agassiz Street Dauphin Island, Alabama 36528, USA

This research centers on the supplementation of microalgal concentrate in the production of oyster larvae Crassostrea virginica, specifically, Shellfish Diet $1800^{\mathrm{TM}}$ testing diet effects on growthrate, composition, survival, and total metamorphosis. This was explored by feeding the larvae live and concentrated algae proportional on an ash-free dry weight (AFDW) basis. Dry weights were determined for live-algae and the concentrate prior to experimentation. The four species cultured are Thalassiosira pseudonana, Isochrysis lutea, Pavlova lutheri, and Tetraselmis chui. The four centrifuged into shellfish-diet are the same genus, but different strains. In experimentation, the feeding rate $\left(\mathrm{mL} / \mathrm{d}^{-1}\right)$ of concentrate was determined based on volume of the culture beaker. The rate determined the total biomass of concentrate and the volume of live-algae in proportion needed to formulate one diet. Six separate diets were fed to culture beakers with the same volume and density of larvae, with four replicates per diet. The density of live-alga cultures (cells $/ \mathrm{mL}^{-1}$ ) was tracked in order to determine lag, log, and stationary phases. Each stage was sampled for AFDW and fitted to the density of culture in cells $/ \mathrm{mL}^{-1}$. This biomass proxy was measured each experimental day for each live culture used. The goal of this method to show which diet blend $(100,80,60$, 40,20 , or $0 \%$ concentrate) has greater significance to production, via increased growth-rates and inherent developmental characteristics of larvae.

\section{EFFECTS OF FISHERIES IN POPULATION SIZE STRUC- TURE OF P ANOPEA GLOBOSA FROM CENTRAL GULF OF CALIFORNIA}

Eugenio Aragón-Noriega

Centro de Investigaciones Biológicas del Noroeste, Unidad Sonora. Km 2.35 Camino al Tular, Estero Bacochibampo, Guaymas, Sonora, 85454, Mexico

This study describes and locates ten beds of Panopea globosa in central Gulf of California suitable to be exploited. The size structure of the geoducks was compared between beds and in the same bed after of three years of fishery stress. A total of 14,613 geoduck were collected, the average length was $138 \pm$ $12.5 \mathrm{~mm}$, significant differences were found between beds $\left(F_{0.95,9,14503}=137.27 ; P=0.00\right)$. The comparative analysis on the same bed showed that four beds remains with no changes in average size after three years of exploitation. Three beds showed significant decrement in average size and the others three beds showed a significant larger average size. The effect of fishery over size diminished has been documented in many fisheries, but in the present study we found this only in three beds. No logical explanation is found for the complete results in the zone, where three beds showed increased in average size and four remains with no changes.

SECOND- AND THIRD-GENERATION LINKAGE MAPS REVEAL ERRORS IN THE ASSEMBLY OF THE PACIFIC OYSTER GENOME

Alberto Arias-Perez ${ }^{1}$, Dennis Hedgecock ${ }^{2}$

${ }^{1}$ Facultade de Ciencias, A Zapateira s/n, 15071 A Coruña, Universidade da Coruña, Spain

${ }^{2}$ University of Southern California, 3616 Trousdale Pkwy, AHF 107, Los Angeles, CA, 90089-0371, USA

Linkage maps are needed to localize genomic regions that influence production traits, such as survival, sex determination, and growth of the Pacific oyster. When combined with the recently published genome (Zhang et al. 2012 Nature), these maps are a path to discovery of the causal genes and physiological mechanisms underlying variation in production traits. First-generation (1G) maps were based on microsatellite DNA and AFLP markers, comprised ten linkage groups, as expected from the chromosome number, but had fairly sparse coverage $(\sim 10 \mathrm{cM})$. Second- $(2 \mathrm{G})$ and third-generation $(3 \mathrm{G})$ maps are based on coding and non- 
coding single-nucleotide polymorphisms (SNPs) and have much denser coverage ( $1 \mathrm{cM}$ or less). $2 \mathrm{G}$ maps are based on 1025 coding SNPs typed in one or more of five families. The first $3 \mathrm{G}$ map is based on nearly 1500 SNPs typed in one large family. The major general result is that, for $\sim 40 \%$ of scaffolds that have two or more mapped markers, supposedly tightly linked SNPs map to two or more different linkage groups, which suggests that the oyster genome contains a large number of miss-assembled scaffolds. The second general result is that consensus linkage maps for the Pacific oyster are difficult to construct, owing to a variety of problems, including widespread distortions of genotype and haplotype frequencies caused by strong selection of early viability. Nevertheless, this and other $3 \mathrm{G}$ maps in progress shed light on genome assembly errors, can aid with genome re-assembly, and provide much denser maps for finding causal genes for variation in production traits.

\section{THE CONDOR OF COMMERCIAL CRABS: COLLAPSE OF THE BLUE KING}

David Armstrong ${ }^{1}$, Chris Long ${ }^{2}$, Janet Armstrong ${ }^{1}$, Sean McDonald ${ }^{1}$, Jake Kvistad $^{1}$

${ }^{1}$ School of Aquatic and Fishery Science, University of Washington, Seattle, WA, 98195, USA

${ }^{2}$ Kodiak Laboratory, Alaska Fisheries Science Center Kodiak Laboratory, 301 Research Court, Kodiak, AK, 99615, USA

Blue king crab (BKC, Paralithodes platypus) have very disjunct, limited distribution in the eastern Bering Sea and once supported a commercial fishery of maximum landings around 5,000 tons in the early 1980s. The Pribilof Islands population supported a major portion of that fishery but biomass declined over $90 \%$ from 30,000 tons in the 1970 s to less than 500 tons at present. The fishery was closed in 1999 and declared overfished in 2002. Despite a rebuilding plan the stock has not recovered in the ensuing 13 years. Life history of $\mathrm{BKC}$ is complex and, in various ways, precarious. Distribution of ovigerous females and major life history events including larval hatch and settlement of small juveniles occur very close to the Pribilofs (and St. Matthew Island to the north). Juveniles up to age $3+$ are especially dependent on benthic refugia composed of cobble with associated biogenic habitat, and shellhash of very limited distribution nearshore around the islands. Given evidence of missing age classes in size frequency data, we surmise that retention of larvae and juvenile recruitment in required habitat is precarious given a pelagic larval phase of three to four months. Yet limited field sampling shows tight distribution of later zoeal stages nearshore around the island, and new ROMSIBM models indicate that larval retention can occur despite general circulation away from the Pribilofs and no other viable source of larval supply in the region. Other hypotheses have been advanced to account for continued low abundance including predation, competition, and intervals of adverse environmental conditions.

\section{ESTIMATING THE IMPACTS OF FISHING AND RECOV- ERY IN THE CLOSED AND OPENED AREAS OF THE GULF OF MAINE, FOCUSING ON SEA SCALLOP MORTALITY \\ Samuel Asci, Kevin Stokesbury}

University of Massachusetts Dartmouth, School for Marine Science and Technology (SMAST), 200 Mill Road, Fairhaven, MA, 02719, USA

The Atlantic sea scallop (Placopecten magellanicus) has historically supported a commercial fishery on the major banks and ledges in the central Gulf of Maine (Jefferys Ledge, Fippennies Ledge, Cashes Ledge, and Platts Bank). Benthic photographs obtained in a manned submersible study conducted in 1986 and 1987 noted significant change in Gulf of Maine community structure due to one year of heavy fishing pressure. This study identified densities of dominant benthic invertebrates including scallops, and observed how these densities were affected after one year of heavy fishing. In 2002, all of these areas with the exception of Platts Bank were closed to trawl and dredge fisheries due to declining populations of commercial groundfish species (i.e., Atlantic cod, haddock, silver hake, and cusk). These areas have been reexamined using the School for Maine Science and Technology drop camera video survey in 2009, 2010, 2011, 2013, and 2014. A strong year class of scallops was observed in 2009 and tracking this year class in the areas closed and opened to fishing will provide an estimation of natural mortality rate. Further, the video surveys enabled the tracking of community structure changes in these open and closed areas and comparisons with the 30-year-old observations. This will enhance the understanding of changes in community structure over a 30 year period, and changes of recently observed opened and closed areas, including estimates of natural mortality for the target commercial species, the sea scallop.

GENETIC PARAMETERS FOR OSHV-1 AND VIBRIO AESTUARIANUS RESISTANCE IN CRASSOSTREA GIGAS: FIRST RESULTS USING CONTROLLED CHALLENGES

Patrick Azema, Marie-Agnès Travers, Jean-Baptiste Lamy, Lionel Dégremont

Ifremer Laboratoire de Génétique et Pathologie des Mollusques Marins, avenue Mus de Loup, 17390 La Tremblade, France

The Pacific oyster Crassostrea gigas regularly suffers mortality outbreaks in France, reducing the commercial production of about 30\% during the last decade. Since 2008 and each year, massive losses involving the herpes virus OsHV-1 $\mu$ var has been observed in C. gigas spat. However, it was shown that the genetic improvement for resistance to OsHV-1 is easily achievable throughout selective breeding program. Unfortunately, significant mortalities related to Vibrio aestuarianus have been reported in C. gigas adults since 2012. In order to assess the genetic basis for the resistance to the vibriosis, and define the 
nature of the genetic correlations for the resistance to OsHV-1 and $V$. aestuarianus, twenty half-sib families, each containing two full-sib families (FSF), were produced at the Ifremer hatchery in March 2013, and kept in controlled condition to prevent the diseases. For each disease, controlled infectious challenges were conducted for the $40 \mathrm{FSF}$ at the spat and juvenile stages, and will be at the adult stage in 2015. The first results showed that mortality related to OsHV-1 decreased for larger oysters while the opposite finding was found for $V$. aestuarianus. Heritability for OsHV-1 resistance was moderate to high at the spat and juvenile stages (0.45-0.80). In contrast, heritability for $V$. aestuarianus resistance was weak $(<0.04)$ at the spat stage, but significantly increased at the juvenile stage (0.150.32). Interestingly, genetic correlation for resistance to both diseases was low and not significantly different from zero indicating that a selective breeding program to develop dual resistance should be feasible.

GENOTYPE BY SIZE INTERACTION FOR OSHV-1 RESISTANCE IN CRASSOSTREA GIGAS

\section{Patrick Azema, Marie-Agnès Travers, Lionel Dégremont}

Ifremer Laboratoire de Génétique et Pathologie des Mollusques Marins, avenue Mus de Loup, 17390 La Tremblade, France

The ostreid herpes virus OsHV-1 causes severe mortality outbreaks in Crassostrea gigas, in particular in spat, and in a lesser extent juveniles and adults. Although it was demonstrated that resistance to the disease increases with size and age, and that size has a higher importance than age, we developed another approach to only focus on the size factor using 40 full-sib families (FSF). The families were produced at the Ifremer hatchery in La Tremblade in March 2013, and they were raised in two environments in our hatchery in order to obtain two groups named "Large" (L) and "Small" (S). For each family and each size, 100 oysters were deployed in the field at Agnas in the Marennes-Oléron Bay in November 2013, when seawater temperature was below $10^{\circ} \mathrm{C}$. The mean individual length and weight at deployment was $15 \mathrm{~mm}$ and $0.4 \mathrm{~g}$ for the $\mathrm{S}$ group, and $32 \mathrm{~mm}$ and $4.7 \mathrm{~g}$ for L group respectively. Mortality was observed when seawater temperature exceeded $16^{\circ} \mathrm{C}$ in June 2014 , which is typical of mortality related to OsHV-1. The mean mortality of the $40 \mathrm{FSF}$ was $70 \%$ and $47 \%$ for the S and L, respectively, in July 2014, and the corresponding mean individual length of the dead oysters was $29 \mathrm{~mm}$ and $42 \mathrm{~mm}$. Even if the L group experienced significant lower mortality than the $\mathrm{S}$ group, it was found a significant interaction between family and size, which was due to the extreme genotypes for which mortality was similar regardless of the size group.
EVALUATION OF RESISTANCE TO VIBRIO AESTUARIANUS THROUGHOUT THREE SUCCESSIVE CHALLENGES USING CRASSOSTREA GIGAS SELECTED AND UNSELECTED FOR THEIR HIGHER RESISTANCE TO OSHV-1 Patrick Azema, Agnès Travers, Lionel Dégremont

Ifremer Laboratoire de Génétique et Pathologie des Mollusques Marins, avenue Mus de Loup, 17390 La Tremblade, France

In addition to the mortality related to the ostreid herpesvirus OsHV-1, significant mortalities related to Vibrio aestuarianus have been observed on market size adults since 2012, threatening the French oyster production of Crassostrea gigas. A mass selection experiment to enhance survival and OsHV-1 resistance in C. gigas spat was successfully carried out for three generations using two wild stocks from 2009 to 2012. Meanwhile, it has been argued that such selection could have led to a higher susceptibility of $C$. gigas to $V$. aestuarianus. Thus, a controlled challenge by $V$. aestuarianus in the laboratory was conducted using selected and unselected oysters for resistance to OsHV-1. The oysters challenged were 15 months old and the individual whole weight was around $20 \mathrm{~g}$ corresponding to the juvenile stage. For both stocks, the selected oysters showed higher survival $(78 \%)$ than the unselected oysters $(32 \%)$. The survivors was kept and challenged again in 2014 at 27 months old and $110 \mathrm{~g}$, corresponding to the adult stage. For both stocks, mortality was observed for both groups, and the cumulative survival after two challenges collapsed to $1 \%$ for the unselected oysters and $18 \%$ for the selected oysters. Finally, a third challenge was conducted at 32 months old and $160 \mathrm{~g}$, and the cumulative survival of the selected oysters decreased to $12 \%$. This experiment highlighted that oysters remained susceptible to the $V$. aestuarianus even if they survived to one or several mortality outbreaks related to the disease.

\section{AN INTERNATIONAL COLLABORATION: DOCUMENT- ING THE NON-NATIVE GREEN MUSSEL, PERNA VIRIDIS, IN CUBA}

Shirley Baker ${ }^{1}$, Alexander Lopeztegui-Castillo ${ }^{2}$, Adriana Artiles-Valor ${ }^{2}$, Yuliesky Garcés-Rodríguez ${ }^{2}$, Roberto Castelo-Báez ${ }^{2}$, Ninieska Castro-Graña ${ }^{3}$

${ }^{1}$ Fisheries and Aquatic Sciences, School of Forest Resources and Conservation, University of Florida, 7922 NW 71st Street, Gainesville, FL, 32653, USA

${ }^{2}$ Fisheries Research Center, 5th Avenue and 246, Barlovento, Playa, Havana, Cuba

${ }^{3}$ Fishery Industry of Cienfuegos, Fertilizers Street, Industry Zone Number 2, Obourke, Cienfuegos, Cuba

In early 2013, scientists in Cuba contacted Baker for English language editing of a manuscript on the green mussel, Perna viridis (Linnaeus 1758). What followed was a conversation and friendship, conducted almost entirely by email, which resulted in 
the publication of a co-authored paper in the Journal of Shellfish Research. The benefits to both parties have been well worth the effort and we would encourage others to develop similar relationships. The objectives of the study were to document the spatial and temporal variation in $P$. viridis density across Cienfuegos Bay and to examine the relationship between $P$. viridis density and water quality patterns within the bay. We found that $P$. viridis density differed across Cienfuegos Bay both temporally and spatially, and that, while salinity may play a role in green mussel distribution and density, other factors are also important. The results of our systematic sampling also revealed dramatic temporal variation in the Cienfuegos Bay $P$. viridis population; over the 22-month study, green mussel density at two of the sampling sites declined by an order of magnitude. There are several possible explanations for the dramatic decline in $P$. viridis density over the sampling period. Among them are mortality resulting from stressful environmental conditions and removal through harvest, both coupled with low recruitment rates. The decline of the population in the bay suggests that this species is not a candidate for a commercial fishery and that manual harvest may be an efficient means of eradication, if desired.

\section{MARKERS ASSOCIATED WITH DISEASE RESISTANCE IN EASTERN OYSTERS, CRASSOSTREA VIRGINICA Kehan Bao ${ }^{1}$, Marta Gomez-Chiarri ${ }^{1}$, Dina Proestou ${ }^{2}$}

${ }^{1}$ University of Rhode Island, Department of Fisheries, Animal and Veterinary Science, 170 CBLS, 120 Flagg Road, Kingston, RI, 02881, USA

${ }^{2}$ Agricultural Research Services, NCWMAC, 469 CBLS, 120 Flagg Road, Kingston, RI, 02881, USA

The eastern oyster, Crassostrea virginica, is an economically important aquaculture species in the USA, but production has been impacted by diseases such as dermo and MSX. Efforts have been put into the development of disease-resistant oyster lines using selective breeding techniques; however, these methods depend on consistent and accurate selection pressure. MarkerAssisted Selection (MAS) utilizes genetic markers associated with disease-resistance and promises accurate selection for resistant oysters in the absence of disease pressure. Several markers associated with dermo and MSX resistance have been identified using selected lines and families, but they need to be verified in further populations. In this study, oysters spawned from NEH broodstock survivors of a Seaside Organism (caused by Haplosporodium costale) outbreak in Rhode Island were deployed in York River, Virginia. Microsatellite markers (20, including 10 markers found to be associated with disease-resistance in previous studies), were used to genotype samples collected before and after a disease-caused mortality period (March 2013 - October 2013). Five out of the 10 markers previously associated with disease resistance (RUCV66, RUCV270, Cvi2i4, Cvi1g3 and Cvi2m10) were verified to have significant shifts in allele frequency postmortality. The analysis also revealed one marker (RUCV68) with a significant shift in allele frequency that had not been identified in previous studies. These six markers will be good candidates for anchor locations for detecting functional genes nearby that underlie disease-resistance. To further confirm the association between these markers and disease-resistance, oysters from the same spawn but reared at a different location (New Jersey) are being tested.

ROLE OF CYTOTOXICITY AND HEMOLYSIS IN THE DELETERIOUS EFFECTS OF ALEXANDRIUM AFFINE AND $A$. CATENELLA ON EARLY-LIFE DEVELOPMENT OF THE JAPANESE PEARL OYSTER, PINCT AD A FUCATA MARTENSII

Leila Basti ${ }^{1}$, Tatsuya Oda ${ }^{2}$, Kiyohito Nagai ${ }^{3}$, Satoshi Nagai ${ }^{1}$

${ }^{1}$ Metagenomics Research Group, National Research Institute of Fisheries Science, Fisheries Research Agency, 2-12-4 Fukuura, Kanazawa-Ku, Yokohama 236-8648, Japan

${ }^{2}$ K. Mikimoto and Co. Ltd., Osaki Hazako, Hamajima-Cho, Shima, Mie 517-0403, Japan

${ }^{3}$ Division of Biochemistry, Faculty of Fisheries, Nagasaki University, Nagasaki 852-8521, Japan

Several species of the genus Alexandrium are responsible for the widespread paralytic shellfish poisoning in humans (PSP) via the consumption of shellfish contaminated with paralytic shellfish toxins (PST). In addition, several species of Alexandrium are known to affect shellfish including bivalve molluscs, and these effects are generally non-PST related. The few studies that have investigated the effects of Alexandrium spp. on the early-life development of bivalves reported inimical effects on spermatozoa, fertilization, and early larvae of Crassostrea gigas, Chlamys farreri, Mercenaria mercenaria, and Argopecten irradians. In a previous study in our laboratory, the non-PST producer Alexandrium affine and the PST-producer Alexandrium catenella were shown to affect embryos and larvae of Japanese pearl oysters, Pinctada fucata martensii. In the present study, the cytotoxic and haemolytic effects of $A$. affine and $A$. catenella on oocytes of $P$. fucata martensii were investigated. The oocytes of pearl oysters were exposed in-vivo to whole cultures or culture supernatants of $A$. affine and A. catenella at cell densities of $10,10^{2}$, and $10^{3}$ cells $\mathrm{mL}^{-1}$, or equivalent cell density for the supernatants. The viability of oocytes was assessed following $3 \mathrm{~h}$ of exposure. The cytotoxic and haemolytic activities of $A$. affine and A. catenella were assessed using Vero cells and rabbit erythrocytes, respectively. All experiments were conducted in duplicate and conducted for the three growth phases of Alexandrium spp., i.e. exponential, stationary, and death phases. 
DETECTING FERTILIZATION SUCCESS IN ARTIFICIAL DOCKSIDE, MANIPULATED SEABED, AND NATURAL POPULATION DENSITY GRADIENTS OF SEA SCALLOPS Skylar Bayer, Richard Wahle, Damian Brady, Pete Jumars

University of Maine, School of Marine Sciences, Darling Marine Center, 193 Clark's Cove Road, Walpole, ME, 04573, USA

Fishing down sedentary broadcast spawners challenges their reproductive success by depleting natural aggregations that are thought to promote high rates of fertilization. The sea scallop, Placopecten magellanicus, is a commercially valuable, sedentary broadcast spawner in the Northwest Atlantic. Although area closures have helped repopulate depleted scallop populations, little is known about how changes in scallop population densities affect reproductive efficiency and ultimately yield. Building on previous laboratory studies, we (1) developed and tested a Nitex mesh chamber to measure relative rates of fertilization success in situ, and (2) conducted a spawning and fertilization assessment of a) dockside, b) manipulated seabed and c) natural population density gradients in a coastal estuary in Maine to determine the relationship between density and fertilization to infer larval production. In the dockside experiment, fertilization rates within $1 \mathrm{~m}$ of nets containing 30 males were ten times as high as those near nets containing only four or one male, and fertilization rates in the latter two treatments were equally low. These results suggested that density effects might be detectable in natural populations spanning 10-fold differences in density. However, in both manipulated and natural populations, we could not detect a significant effect of density or distance on fertilization. Our experiments are the first field assays of fertilization with scallops. They suggest that differences in fertilization may only be detectable across population density gradients in the event of mass, synchronous, spawning or across more dramatic differences in population density that we could only produce in dockside manipulations.

GREEN CRAB, CARCINUS MAENAS, POPULATION DYNAMICS IN THE HARRASEEKET RIVER, FREEPORT, MAINE (2013-2014)

Brian F. Beal ${ }^{1}$, Chad Coffin ${ }^{2}$, Clint Goodenow ${ }^{2}$, Sara Randall ${ }^{3}$

${ }^{1}$ University of Maine at Machias, Environmental \& Biological Sciences Division, Machias, ME, 04654, USA

${ }^{2}$ Stewards of the Sea, LLC, Freeport, ME, 04032, USA

${ }^{3}$ Downeast Institute, Beals, ME, 04611, USA

Spatial and temporal variation in abundance, size-frequency, and sex ratio of green crabs, Carcinus maenas, were assessed in northern Casco Bay, Maine (Harraseeket River, Freeport) during May-October 2013-2014 in both intertidal and subtidal areas. Circular, vinyl-coated wire traps ( $45 \mathrm{~cm}$ diameter $\times 90 \mathrm{~cm}$ long) baited with crushed soft-shell clams, Mya arenaria, were used to capture crabs. Traps were fished every 3 days in 2013. A small-scale sampling study was conducted during June to determine if catchper-unit-effort increased when traps were allowed to fish for 1,2, or 3 days prior to sampling. In 2014, traps were fished three times a week after 1-, 2-, and 4-day sets. In both years, catches remained somewhat constant through the summer, and then increased in September and October. After a relatively cold winter and spring, average biomass in 2014 was ca. 90\% less than it was in 2013 (4.5 vs. $0.45 \mathrm{~kg} / \mathrm{trap}$ ); however, number of crabs $/ \mathrm{kg}$ in 2014 was $3.5 \times$ greater than in $2013(97 / \mathrm{kg}$ vs. $27 / \mathrm{kg})$. Catches in both years did not increase significantly with increasing time that traps remained on the bottom. Sex ratios were biased towards males (ca. 70:30) in both years.

WHAT EARLY LIFE HISTORY TELLS US ABOUT RESTORATION SUCCESS IN OLYMPIA OYSTERS

Bonnie J. Becker ${ }^{1}$, Michael D. Behrens ${ }^{2}$, Brian Allen ${ }^{3}$, Brent Vadopalas $^{4}$, Megan Hintz ${ }^{1}$, Hannah Parker ${ }^{1}$

${ }^{1}$ University of Washington Tacoma, Interdisciplinary Arts and Sciences, 1900 Commerce Street, Box 358436, Tacoma, WA, 98402, USA

${ }^{2}$ Pacific Lutheran University, Biology Department, Rieke Science Center, Tacoma, WA, 98447, USA

${ }^{3}$ Puget Sound Restoration Fund, 590 Madison Avenue N., Bainbridge Island, WA, 98110, USA

${ }^{4}$ University of Washington, School of Aquatic and Fishery Sciences, Box 355020, Seattle, WA, 98195, USA

Native Olympia oysters have been the subject of widespread restoration efforts across the west coast, including in Puget Sound. Ultimately, the goal of restoration is to establish populations that are self-sustaining or exporting new offspring. Predicting larval behaviors and settlement preferences can allow practitioners to design habitats, choose sites, and distribute restoration networks more effectively. The purpose of this study was to map the spatial and temporal distribution of oyster larvae and settlers in a bay in Puget Sound that has been the subject of restoration work over the past decade. From April through July 2013, we monitored the reproductive state of adults and the relative abundance and distribution of larvae and spatfall. Analyses are ongoing, although adult data indicate low reproductive synchrony and settler data reveal that juvenile oysters settled preferentially near adult oysters rather than across depths and locations. We will compare larval distribution data to determine if larvae are distributed throughout the area and are preferentially settling in optimal habitat, or if they remain in specific areas throughout the dispersal period. These results will be used to improve restoration efforts and to inform our upcoming studies of larval dispersal of this important ecosystem engineer throughout Puget Sound. 
EVALUATING THE EFFECTS OF OCEAN ACIDIFICATION ON THE MECHANICS AND STRUCTURE OF SOUTHERN TANNER CRAB MINERALIZED TISSUE

Shai Bejerano ${ }^{1}$, Christine Makdisi ${ }^{1}$, W. Christopher Long ${ }^{2}$, Katherine Swiney ${ }^{2}$, Robert Foy ${ }^{2}$, Gary H. Dickinson ${ }^{1}$

${ }^{1}$ The College of New Jersey, Department of Biology, 2000 Pennington Road, Ewing, NJ, 08628, USA

${ }^{2}$ NOAA, National Marine Fisheries Service, Alaska Fisheries Science Center, Resource Assessment and Conservation Engineering Division, Kodiak Laboratory, 301 Research Court, Kodiak, AK, 99615, USA

Increasing levels of atmospheric carbon dioxide have led to a reduction in the $\mathrm{pH}$ of ocean waters (i.e. ocean acidification, OA) and an associated drop in calcium carbonate saturation states. In many taxa, these changes in seawater chemistry affect the ability of calcifying organisms to build and maintain mineralized tissue. To date, few studies have assessed the effect of OA on mineralized tissue in crustaceans. This study examines the effects of decreased $\mathrm{pH}$ on mechanical and structural properties of the mineralized cuticle in southern Tanner crabs, Chionoecetes bairdi. Mature multiparous female southern Tanner crabs were exposed to one of three $\mathrm{pH}$ levels (8.1 (ambient), 7.8, and 7.5) for two years. Following exposures, the carapace and chelae were dissected, sectioned longitudinally, embedded in epoxy resin and polished. Sectioning exposed the two distinct mineralized layers of the cuticle, the inner endocuticle and outer exocuticle, enabling separate analyses in each region. For the carapace, microhardness (a measure of a material's resistance to deformation) was significantly reduced at $\mathrm{pH} 7.5$ in the endocuticle but not the exocuticle. Likewise, thickness of the endocuticle in crabs exposed to $\mathrm{pH} 7.5$ was significantly reduced, whereas thickness of the exocuticle was not affected by $\mathrm{pH}$. Initial microhardness testing of chelae revealed a trend toward reduced microhardness in the exocuticle but not the endocuticle in lower $\mathrm{pH}$ treatments. Results suggest that OA negatively affects the ability of southern Tanner crabs to maintain calcified tissue, potentially compromising structural integrity of the crab cuticle.

OVERFILTRATION OF MARINE DISEASES I: EXPERIMENTAL EVIDENCE AND NOTES FROM THE FIELD Tal Ben-Horin ${ }^{1}$, Gorka Bidegain ${ }^{2}$, Eric N. Powell ${ }^{2}$, David Bushek ${ }^{1}$

${ }^{1}$ Haskin Shellfish Research Laboratory, Department of Marine and Coastal Sciences, Rutgers University, 6959 Miller Avenue, Port Norris, NJ, 08349, USA

${ }^{2}$ University of Southern Mississippi, Gulf Coast Research Laboratory, 703 East Beach Drive, Ocean Springs, MS, 39564, USA

Parasites with free-living life stages often function as prey to generalist consumers. Their ubiquity throughout the water column suggests that parasite consumption is a major pathway for disease transmission in nearshore marine systems, particularly for sessile hosts that rely on suspension and deposit feeding activities to contact food particles. Competition for suspended particles, and its impact on per capita consumption, is well documented, however, only recently has competition for water-borne parasites been considered in studies of disease transmission. To illustrate this central connection between competition and disease transmission, we present results from mesocosm experiments varying the density of oysters and the dose of the etiological agent of Dermo disease, Perkinsus marinus. We found that the incidence of Dermo climbed with increasing per capita dose of Perkinsus marinus, but due to increased competition for suspended particles, fell with oyster density. The net result of such a competitive interaction via pathogen consumption is to inhibit the spread of disease, a phenomenon we describe as overfiltration. Overfiltration is challenging to predict in nature, but this concept delivers a new perspective for evaluating the observed persistence of Dermo disease in mid-Atlantic estuaries following the decline of oysters due to MSX. Can dense oyster populations overfilter Perkinsus marinus and minimize the impact of disease? The answer to this question will have important consequences for the management of oyster fisheries and oyster restoration anywhere Dermo is present.

\section{PRESENCE OF OCTOPAMINE RECEPTORS IN HEART OF THE EASTERN OYSTER, CRASSOSTREA VIRGINICA}

Fiana Bess, Ave Harris, Christopher Welsh, Edward J. Catapane, Margaret A. Carroll

Medgar Evers College, 1638 Bedford Avenue, Brooklyn, NY, 11225, USA

Octopamine (OA), a biogenic amine first identified in octopus, is well studied in arthropods and gastropods where it functions as a neurotransmitter and hormone. OA rarely has been reported in bivalves. Using HPLC, OA was found in ganglia, gill, heart, palps and hemolymph of the oyster Crassostrea virginica and, using immunohistofluorescence, OA was visualized in ganglia, gill and heart. Physiological studies found OA is cardioactive for $C$. virginica and Mytilus edulis hearts. These findings prompted the hypothesis OA receptors are present in heart of $C$. virginica. Western Blot (WB) was performed to test this using pan TAAR (trace amine-associated receptor) 1 ? antibodies, which are reactive with OA, beta-phenylethylamine (b-PEA), p-tyramine (p-TYR), and tryptamine receptors, but unresponsive to classical biogenic amines and histamine receptors. For WB, heart tissue lysate was prepared in NP-40 detergent buffer containing protease inhibitor, followed by centrifuging to obtain supernatant with solubilized membrane proteins. Up to $30 \mu \mathrm{g}$ of solubilized protein was subjected to SDS-PAGE with $10 \%$ acrylamide gels and electroblotted onto nitrocellulose. Pan TAAR receptor immunoreactivity was revealed by $1^{\circ}$ antibodies followed by HRP-conjugated $2^{\circ}$ antibodies. WB showed an $85 \mathrm{kD}$ band corresponding to OA receptors in heart. The present project, coupled with earlier studies, 
confirms the presence of OA receptors and furthers understanding of a physiological role for OA in C. virginica.

OVERFILTRATION OF MARINE DISEASES II: COMPARTMENTAL MODELS AND WATER COLUMN SIMULATIONS Gorka Bidegain $^{1}$, Tal Ben-Horin ${ }^{2}$, Eric N. Powell ${ }^{1}$, John M. Klinck ${ }^{3}$, David Bushek $^{2}$, Eileen E. Hofmann ${ }^{3}$

${ }^{1}$ University of Southern Mississippi, Gulf Coast Research Laboratory, 703 East Beach Drive, Ocean Springs, MS, 39564, USA

${ }^{2}$ Haskin Shellfish Research Laboratory, Institute of Marine and Coastal Sciences, Rutgers University, 6959 Miller Avenue, Port Norris, NJ, 08349

${ }^{3}$ Old Dominion University, Center for Coastal Physical Oceanography, 4111 Monarch Way, Norfolk, VA, 23508, USA

Disease transmission in filter feeders often occurs directly via filtration of waterborne pathogens. The relationship between host density, pathogen dilution and disease risk was explored using a compartmental model, which incorporates the effect of a doseresponse mechanism and the potential of a remote volume, adjacent to the local volume directly influenced by filtration, to modulate the infection process through diffusional exchange of particles with the local volume. The basic reproduction number, $R_{0}$, a measure of disease risk that serves as a threshold parameter for disease outbreak was estimated. Two major mechanisms limiting epizootic development were identified. The first, overfiltration, occurs when a dense assemblage of filter feeders effectively removes pathogens from the system by refiltering water many times over. In this case, each animal acquires on average a reduced number of particles, so that once the population rises above a certain initial population the maximal $R_{0}$ is attained and remains constant. Epizootic development was found to be limited by a diffusive effect, where a large remote volume leads to a system with an effective mechanism to purge pathogens accessible to benthic filter feeders. Whether the epizootic develops (i.e. $R o>1$ ) depends on the balance between the in vivo inactivation of pathogens and the rate of particle acquisition through filtering that determines whether the body burden of infective particles will exceed the infective dose. Preliminary 3-D simulations using the hydrodynamic model ROMS coupled to a benthic model, confirm the overfiltration effect over a dense oyster reef resulting in turns in a reduction of downstream pathogen flux and a dilution of the disease risk both locally and in neighboring reefs.

\section{DETERMINING POPULATION STRUCTURE, REPRODUC- TIVE POTENTIAL AND HABITAT ASSOCIATIONS OF THREADED ABALONE IN SOUTHERN CALIFORNIA Amanda Bird, D. Zacherl}

California State University Fullerton, Department of Biological Science, Fullerton, CA, 92831, USA
Seven species of abalone are found in subtidal kelp forests along the coast of California, five of which once supported viable commercial and recreational fisheries. However, stock collapse led to the closure of fisheries in central and southern California in 1997. The threaded abalone, (Haliotis kamtschatkana assimilis), a subspecies of pinto abalone, once supported a modest commercial fishery in southern California. In July 2013, NMFS was petitioned to list the pinto abalone as threatened or endangered under the ESA. However, management strategies are not available for threaded abalone due to the lack of basic demographic knowledge and entire populations and their habitat may be inadvertently excluded from protection. Preliminary surveys in San Diego, CA, where one of the only currently known populations of threaded abalone are present, show threaded abalone density increases significantly with increasing depth and decreasing latitude. There is evidence of recent threaded abalone recruitment; individuals within the population represent a broad size range $(30-160 \mathrm{~mm}$ maximum shell length). Ongoing surveys will continue to examine population structure, habitat characteristics and reproductive potential for threaded abalone in San Diego. These data and procedures will inform recovery efforts for threaded abalone and other abalone.

\section{WILD SPAT COLLECTION, WINTER GROWTH AND SUR- VIVAL OF SINGLE OYSTERS (CRASSOSTREA VIRGIN- ICA) IN COASTAL GEORGIA \\ Thomas Bliss, Justin Manley}

University of Georgia Marine Extension Service Shellfish Research Laboratory, 20 Ocean Science Circle, Savannah, GA, 31411, USA

The development of single oyster (Crassostrea virginica) aquaculture in Georgia is of utmost importance to diversify the shellfish industry that is currently dominated by the northen quahog (= hard clam) (Mercenaria mercenaria). To jump start single oyster aquaculture, until a hatchery opens at the University of Georgia Marine Extension Service (MAREX) in 2015, wild spat were collected to distribute to shellfish growers. Spat was collected using untreated $19 \mathrm{~mm}(3 / 4 \mathrm{inch}) \mathrm{cPVC}$ that was set out in the intertidal zone of the Skidaway River in March 2014. Sticks were placed adjacent to natural and restored oyster beds and were checked periodically for oyster set and spat was removed when 1-7 mm in size from May-July 2014. Approximately 500,000 spat were collected and held in $1 \mathrm{~mm}$ mesh pearl nets and had a mean height of $10.0 \mathrm{~mm}(+0.5 \mathrm{SE})$ at the end of July 2014. Spat were transferred to a floating upweller system in September and held until November 3, 2014 when spat were distributed to ten growers. Each grower received 20,000 seed retained on $19 \mathrm{~mm}$ (3/4 inch) screen along with grow out bags and supplies to construct inter-tidal racks. Winter survival and growth will be calculated on a bi-monthly schedule until March 2015 when oysters will be moved to summer grow-out. 
THE DEVELOPING OFFSHORE WHELK (BUCCINUM UNDATUM) FISHERY IN THE MID-ATLANTIC

Eleanor Bochenek, Sean Martin, Daphne Munroe, Sarah Borsetti

Haskin Shellfish Research Laboratory, Rutgers University, 6959 Miller Avenue, Port Norris, NJ, 08349, USA

A new commercial fishery is developing in the Mid-Atlantic targeting offshore whelk (Buccinum undatum). The fishery began three years ago off the coast of New Jersey and is primarily conducted in areas where Atlantic scallops occur. Offshore whelk are scavengers and likely feed on discarded scallop waste from onboard scallop processing in the scallop fishery and other organisms dislodged during scallop dredging. A commercial whelk fishery has existed in eastern Canada and northern Europe for many years using baited commercial traps. Mid-Atlantic fishers use the same commercial traps as those used in the Canadian fishery. Pots are baited with skate, bunker, or other inexpensive bait and fished on strings of 75 pots. Soak time ranges from two to seven days and fishers tend to target whelk after the scallop season to prevent loss of gear via interactions with scallop dredges. Captured whelk are kept on ice or sprayed with chilled seawater to keep them cool. Markets for the whole frozen in-shell whelk are primarily Asian markets in New York City and Boston, with some sold as far away as San Francisco. Product is also shipped to Europe and Asia. Price per pound has steadily risen in response to increasing demand over the few years over which the new fishery has been in operation. Dockside price was originally $\$ 0.55$ per pound in 2012, which increased to $\$ 0.70$ and is currently $\$ 0.90$. Current issues and more detail about the fishery and markets will be discussed.

\section{HISTAMINE AND HISTAMINE RECEPTOR INVOLVE- MENT IN SENSORY-MOTOR INTEGRATION OF GILL LATERAL CELL CILIA ACTIVITY IN THE BIVALVE CRASSOSTREA VIRGINICA}

Beatrix Boisette, Ave Harris, Patrick Akande, Edward J. Catapane, Margaret A. Carroll

Medgar Evers College, 1638 Bedford Avenue, Brooklyn, NY, 11225, USA

Gill lateral ciliated cells of Crassostrea virginica are innervated by serotonin and dopamine nerves. Motor aspects have been well studied, but the sensory side hasn't. Histamine (HIS) a neurotransmitter in a variety of invertebrates rarely has been reported in bivalves. Previously, HIS was quantified in $C$. virginica and it was found gill lateral cell cilia beating changed in response to mantle sensory inputs including HIS. The mechanism involves mantle rim sensory tentacles and visceral ganglia. HIS does not alter beating when applied to gill. These results prompted the hypothesis HIS receptors are present in mantle and can be confirmed by Western Blot (WB). For WB, mantle body and rim lysates were prepared in NP-40 detergent buffer containing protease inhibitor followed by centrifuging to obtain supernatant with solubilized mantle body and rim membrane proteins. $\mathrm{H} 2$ receptor immunoreactivity was revealed by $1^{\circ}$ antibody followed by HRP-conjugated $2^{\circ}$ antibody. Mantle body and rim $\mathrm{H} 2$ receptor protein was resolved by colormetric development using CN/DAB substrate kit. A dose response of $\mathrm{HIS} \mathrm{H} 1, \mathrm{H} 2$ and $\mathrm{H} 3$ receptor agonists and antagonist at the mantle rim was conducted and cilia beating in gill observed. WB showed a $70 \mathrm{kD}$ band corresponding to HIS H2 receptors in mantle body and rim, and $\mathrm{H} 2$ agonists and antagonists had the strongest effects on cilia beating. The study shows mantle body and rim have HIS $\mathrm{H} 2$ receptors and demonstrates a physiological role of HIS in sensory-motor integration of gill lateral cell cilia activity.

FACTORS AFFECTING VALUE OF OFF-BOTTOM OYSTER AQUACULTURE CAGES AS HABITAT FOR JUVENILE BLUE CRAB

Rebekah Borgert $^{1}$, James Stoeckel ${ }^{1}$, William Walton ${ }^{1}$, Ken Heck ${ }^{2}$, William Daniels ${ }^{1}$

${ }^{1}$ Auburn University, School of Fisheries, Aquaculture and Aquatic Sciences, Dauphin Island, AL, 36528, USA

${ }^{2}$ University of South Alabama, Dauphin Island Sea Lab, Dauphin Island, AL, 36528, USA

Oyster reefs provide valuable ecosystem services, including provision of habitat and/or refuge for other aquatic organisms. Oysters are in worldwide decline and their reefs and associated ecosystem services have dwindled during the past several decades The blue crab (Callinectes sapidus), an especially valuable fishery species along the eastern and gulf coast of the United States, uses oyster reefs as nursery and foraging habitats, and as refuge from predators. We investigated the potential of Australian long-line oyster aquaculture cages as habitat for juvenile blue crabs in Portersville Bay, AL during Summer/Fall 2014. An abundance of juvenile crabs was found on/in cages containing oysters was not significantly greater than that on/in cages without oysters, suggesting that crabs were primarily attracted by the physical structure of the cages, rather than by the oysters themselves. However, an observed lack of juvenile crabs on/in any cages that contained an adult crab suggested that the potential value of oyster cages as habitat for juvenile crabs was degraded by crabs that had previously entered empty cages at a small size but then grew too large to exit. Current experiments are examining whether lack of juvenile blue crabs in occupied oyster cages was due to avoidance, intraspecific predation, or a combination of both. Regardless of the mechanism, the presence of juvenile crabs that grow too large to exit the cages is a factor that will need to be resolved by management practices in order to maximize the value of long-line oyster aquaculture systems as habitat for juvenile blue crabs. 
IDENTIFICATION OF THALASSINIDEAN SHRIMP FOOD SOURCES IN AN OREGON ESTUARY USING FATTY ACID ANALYSIS AND STABLE ISOTOPE RATIOS

Katelyn M. Bosley ${ }^{1}$, Louise A. Copeman ${ }^{2}$, Brett R. Dumbauld ${ }^{3}$

${ }^{1}$ Department of Fisheries and Wildlife, Oregon State University, Hatfield Marine Science Center, Newport, OR, 97265, USA

${ }^{2}$ College of Earth, Ocean, and Atmospheric Sciences, Oregon State University, Hatfield Marine Science Center, Newport, OR, 97365, USA

${ }^{3}$ US Department of Agriculture - ARS, Hatfield Marine Science Center, 2111 SE Marine Science Dr., Newport, OR, 97365, USA

Two species of burrowing shrimps occur in high densities in U.S. West Coast estuaries, the ghost shrimp (Neotrypaea californiensis) and the blue mud shrimp (Upogebia pugettensis). Together these two species of shrimp are considered ecosystem engineers as they burrow and turn over sediment which causes problems for shellfish growers. While their burrows create a dominant habitat type in the Yaquina Bay estuary on the central Oregon coast, little is known about their diet and their role in the estuarine food web. The primary goals of this study were to identify major components of burrowing shrimp diets and detect variation in shrimp diets along an estuarine gradient using a combination of fatty acid (FA) and stable isotope (SI) analyses. A total of 137 shrimp were sampled from several locations within the Yaquina Bay estuary in August 2012. An additional 178 samples of potential food sources for these shrimp were also taken including eelgrass blades, epiphytes, Ulva, sediment surface, sediment core, burrow wall and particulate organic material (POM). Both SI and FA analysis indicated a significant difference in food ingested by shrimp along the estuarine gradient with both species showing highest contribution from POM and epiphytes. Shrimp from lower estuarine sites had high levels of 16:1107 and EPA suggesting a diet high in algae and marine diatoms. Shrimp from upriver showed greater amounts of FA associated with dinoflagellates and terrestrial sources. This is the first study to evaluate diets of these two shrimp using complimentary FA and SI approaches.

FAUNAL USE AND INTERACTIONS AMONG RESTORED OYSTER REEFS AND EELGRASS AT THE SAN FRANCISCO BAY LIVING SHORELINES: NEARSHORE LINKAGES PROJECT

Katharyn Boyer, Cassie Pinnell, Jen Miller, Julien Moderan, Kevin Stockmann

San Francisco State University, Romberg Tiburon Center, 3150 Paradise Drive, Tiburon, CA, 94920, USA

In the two years since installation of the San Francisco Bay Living Shorelines Project, we have monitored use of restored habitat treatments (oyster shell reef and eelgrass, both alone and together, versus no added structure) by epifaunal invertebrates and fish. Eelgrass reached $125 \%$ of planted densities by July 2014 , and native oysters recruited early and heavily to the reefs. Trapping with minnow and oval traps showed an increase in invertebrates preferring physical structure, including bay shrimp and Dungeness crab. Suction sampling indicated that epibenthic invertebrate assemblages are distinct in structured habitat relative to control and pre-construction conditions. Freshwater dips of restored eelgrass shoots revealed invertebrate assemblage differences where oyster reef is present along with eelgrass. Invertebrate assemblages on eelgrass at the restored site have not converged with those at natural beds across the bay, with two native species known to graze eelgrass epiphytes notably absent at the restored site. Fish trapping showed black surfperch and bay pipefish had greater association with eelgrass habitat and Pacific staghorn sculpin with oyster reef. Both trapping and seining indicated eelgrass presence increases the diversity or abundance of fish and invertebrates present on oyster reefs. Acoustic monitoring of tagged fish found visitation by green and white sturgeon, leopard shark, steelhead, and striped bass; positional analysis is underway to determine if fish are exhibiting preferences among the treatments. Further, isotopic analysis of food web relationships is in progress to assess the degree to which the restored habitats and associated species interact.

TOWARDS AN UNDERSTANDING OF THE ROLE OF MICROBES IN NUTRIENT DYNAMICS ON SALMON FARMS: IMPLICATIONS FOR INTEGRATED MULTITROPHIC AQUACULTURE (IMTA)

Hannah Bradford ${ }^{1}$, Shawn Robinson ${ }^{2}$, Bruce MacDonald ${ }^{2}$, Keng Pee Ang ${ }^{3}$, Benjamin Forward ${ }^{4}$, David Thumbi ${ }^{4}$, Thierry Chopin ${ }^{1}$

${ }^{1}$ University of New Brunswick, P.O. Box 5050, Saint John, NB, E2L 4L5, Canada

${ }^{2}$ Fisheries and Oceans Canada, Biological Station, St. Andrews, NB, E5B 2L9, Canada

${ }^{3}$ Cooke Aquaculture Inc., 255 Metcalf Street, Saint John, NB, E2K IK7, Canada

${ }^{4}$ Research Productivity Council, 921 College Hill Road, Fredericton, NB, E3B 6Z9, Canada

Microbes are now more recognized as having a significant influence on the reintroduction of carbon into marine food webs. Since open-water aquaculture of finfish introduces large amounts of organic carbon in the environment from the feeding operations, understanding the role microbes play in the conversion of this excess material and energy is important to understanding farm management from an Integrated Multi-Trophic Aquaculture (IMTA) perspective. This project was conducted in the Bay of Fundy in eastern Canada on a commercial salmon (Salmo salar) farm in Passamaquoddy Bay. Benthic and pelagic samples were collected spatially $(0,50,150,300 \mathrm{~m}$ from the farm and reference at 
$1000 \mathrm{~m}$ ) and seasonally. Microbial rates of carbon conversion were estimated from community respiration rates with an oxygen optode technique using filtered $(0.22 \mu \mathrm{m})$ samples. Abundance values were estimated by epi-fluorescent staining (DAPI) and captured using imaging software. The results suggest that microbial communities are more abundant in proximity to aquaculture farms and convert significant quantities of organic carbon into inorganic forms. Much of that activity occurs in the near-field benthic zone where the majority of the organic waste from the farming operation settles. The implications of these results for aquaculture farm management strategies include designing the efficient placement of the different IMTA components, estimating the assimilative capacity of the environment and determining parameters for the production and fallowing periods. Future options may be the creation of high surface area, false bottom infrastructure beneath aquaculture farms to increase bioconversion by microbes and to supplement space for benthic deposit-feeding species.

IMPACT OF A CONSTRUCTED OLYMPIA OYSTER RESTORATION PROJECT ON AN ADJACENT EELGRASS (ZOSTERA MARINA) BED

S.K. Briley ${ }^{1}$, R.R. Ware ${ }^{2}$, C.R. Whitcraft ${ }^{3}$, D.C. Zacherl ${ }^{1}$

${ }^{1}$ California State University Fullerton, Department of Biological Science, Fullerton, CA, 92831, USA

${ }^{2}$ Coastal Resources Management, 144 N. Loreta Walk, Long Beach, CA, 90803, USA

${ }^{3}$ California State University Long Beach, Department of Biological Sciences, Long Beach, CA, 90840, USA

Recent restoration efforts for the native Olympia oyster, Ostrea lurida, are commonly motivated by potential return of ecosystem services, including increased water filtration. The impact of these services on another species of restoration concern, eelgrass Zostera marina, is unclear, but is hypothesized to be positive if oyster filter feeding behavior increases light penetration to eelgrass. For two years after installation of a constructed oyster bed we monitored eelgrass response in an adjacent eelgrass bed compared to two nearby reference eelgrass beds through changes in water column light intensity, shoot density and biomass. Two years after construction, no clear positive impacts of the oyster restoration on eelgrass shoot density or light intensity were seen; however no strong negative impacts were seen either. Eelgrass shoot density and light intensity varied similarly across all eelgrass beds over time, showing no sign of impact by the restored oyster bed. Eelgrass below-ground biomass was potentially negatively impacted after one year by the oyster bed; however two years after construction, below-ground biomass did not differ significantly from preconstruction levels. These findings support the potential coexistence of a restored Olympia oyster bed shoreward of an existing eelgrass bed, which is relevant to the design of future restoration efforts for both species.

DETECTION OF VIBRIO PARAHAEMOLYTICUS AND VIBRIO VULNIFICUS IN OYSTER TISSUE, SEDIMENT, AND WATER SAMPLES, AND THEIR CORRELATION TO CHLOROPHYLL LEVELS THROUGHOUT RHODE ISLAND AND MASSACHUSETTS

Alexandra Brown, Kathryn Markey, Roxanna Smolowitz

Roger Williams University, One Old Ferry Road, Bristol, RI, 02809, USA

The Gram negative bacteria, Vibrio parahaemolyticus (Vp) and Vibrio vulnificus $(\mathrm{Vv})$, are part of the natural flora in estuarine and coastal marine waters. The bacteria can pose serious health risks to humans, especially those who are immunocompromised and consume raw shellfish that have accumulated $\mathrm{Vp}$ or who have a wound and come into contact with seawater containing high levels of Vv. In this study, a duplex qPCR will be utilized to determine the levels of $\mathrm{Vp}$ and $\mathrm{Vv}$ in oyster tissue, sediments, and water column samples from two locations in Rhode Island and Massachusetts at several time points from spring through fall. The first objective of this study will be to determine the relationship between abundance of $\mathrm{Vp}$ and $\mathrm{Vv}$ in these three types of samples. A second objective will be to determine the chlorophyll levels in the water column samples from these same sites to determine the association of phytoplankton with $\mathrm{Vp}$ and $\mathrm{Vv}$ levels. These data will be used to determine the relationship between sediment, water, tissue, and plankton in order to understand the correlation between oyster tissue levels of $\mathrm{Vp}$ and $\mathrm{Vv}$ and the levels of $\mathrm{Vp}$ and $\mathrm{Vv}$ in the surrounding environment which will then be compared to literature pertaining to Vibrio abundance in the southern United States. This information will be provided to our public health and fisheries biologists in RI and MA and will be used to help develop policies and regulations regarding $\mathrm{Vp}$ and $\mathrm{Vv}$ in the New England environment.

\section{A USER-FRIENDLY, ONLINE MODEL FOR ESTIMATING THE ECOSYSTEM IMPACT OF OYSTER RESTORATION}

\section{Mark Brush, Lisa Kellogg, Emily Skeehan}

Virginia Institute of Marine Science, College of William and Mary, Gloucester Point, VA, USA

Oyster reef restoration is increasingly being proposed with the goals of sequestering nutrients, improving water quality, restoring habitat, and enhancing ecosystem services. However, relatively few quantitative tools exist to compute the ecosystem-level benefits of oyster restoration. User-friendly, readily accessible tools are needed by resource managers, restoration ecologists, and local 
communities to assist in site selection and predict the benefits of restoration. We have developed a web-accessible model that allows restoration practitioners and resource managers to easily estimate the system-level water quality benefits of oyster reef restoration, run restoration scenarios to optimize restoration planning and implementation, and simulate the impact of land use and climate change on reef function. The model has been implemented in three small sub-estuaries of Chesapeake Bay, Harris Creek and the West-Rhode Rivers, MD, and the Lynnhaven River, VA. The model has simple, user-entered inputs for the total acreage and density of restored reefs and mean oyster size, and predicts water quality benefits including: (1) volume of water filtered, (2) amount of sediment and chlorophyll removed from the water column, (3) amounts of $\mathrm{N}$ and $\mathrm{P}$ assimilated in animal tissues and shells, (4) amount of $\mathrm{N}$ removed via denitrification, (5) amounts of $\mathrm{N}$ and $\mathrm{P}$ buried in the sediments, and (6) the economic value of total $\mathrm{N}$ and $\mathrm{P}$ removal. The model is served online for direct use by stakeholders without the need for extensive modeling expertise or purchase of software, and is readily adaptable to other systems around the Mid-Atlantic.

\section{SUSTAINABLE FISHERY MANAGEMENT AND OYSTER POPULATION ENHANCEMENT: A CASE STUDY IN DELAWARE BAY}

David Bushek $^{1}$, Kathryn Ashton-Alcox ${ }^{1}$, Eric Powell ${ }^{2}$

${ }^{1}$ Rutgers University, Haskin Shellfish Research Laboratory, 6959 Miller Avenue, Port Norris, NJ, 08349, USA

${ }^{2}$ Gulf Coast Research Laboratory, 703 East Beach Road, Ocean Springs, MS, 39564, USA

Opinions on maintaining, managing, and restoring oyster populations are often biased by the apparently opposing objectives of conservation and exploitation. 'Sustainability' is often used to bridge the differences in goals but successful examples are rare. The New Jersey-Delaware Bay oyster resource has been successfully managed for decades, allowing the population, habitat, and fishery to be preserved. Oyster disease decimated the resource and crippled the industry years ago and is still prevalent, yet both have survived through rigorous and intensive adaptive management. The fishery operates in the upper half of Delaware Bay with oysters located elsewhere functioning as sanctuaries or reserves. Within the fished beds, non-fishing mortality accounts for $87 \%$ of annual oyster mortality. Area management and a strict quota result in annual harvests below $2 \%$ of the oysters within the fished population. The industry taxes itself for every bushel harvested to raise money for maintaining and enhancing the oyster population. Planting clean shell in the Delaware Bay routinely enhances natural oyster recruitment compared to non-planted areas on the same bed. This enhancement persists for multiple years as oysters continue to set on the planted shell and each generation of newly recruited oysters. The enhancement creates and maintains habitat within the sustain- ably fished population that helps fulfill the ecological service goals described in many oyster restoration programs. Thus, quantifying ecosystem services derived from sustainable fisheries is essential to developing a comprehensive ecosystem management program.

STREAMLINING BIOSECURITY MANAGEMENT IN THE CONTEXT OF REGIONAL MOLLUSCAN SHELLFISH TRANSFERS

David Bushek ${ }^{1}$, Ryan Carnegie ${ }^{2}$, Lisa Calvo ${ }^{1}$, Robert Rheault ${ }^{3}$, Deborah Bouchard $^{4}$, Marcy Nelson ${ }^{5}$, Karen Hudson ${ }^{2}$, Lori Gustafson ${ }^{6}$, Lynn Creekmore ${ }^{6}$

${ }^{1}$ Haskin Shellfish Res. Lab., 6959 Miller Avenue, Port Norris, NJ, 08349, USA

${ }^{2}$ Virginia Institute of Marine Science, Route 1208 Greate Rd., Gloucester Point, VA, 23062, USA

${ }^{3}$ East Coast Shellfish Growers Assn., 1121 Mooresfield Road, Wakefield, RI, 02879, USA

${ }^{4}$ University of Maine, 5735 Hitchner Hall, Orono, ME, 04469 , USA

${ }^{5}$ Maine Dept. of Marine Resources, P.O. Box 8, W. Boothbay Harbor, ME, 04575, USA

${ }^{6}$ National Surveillance Unit, USDA/APHIS/VS/CEAH, 2150 Centre Avenue, Bldg. B, Mail Stop 2E6, Fort Collins, CO, 80526, USA

As shellfish aquaculture continues to expand, so does the transfer of shellfish seed and the potential for disease transfer. Without any regional or larger regulatory structure, each state is left to develop its own system of guidelines and regulation for minimizing risk related to seed transport. To address this situation we have gathered shellfish pathologists, shellfish regulators (federal, state and local), shellfish producers and shellfish researchers to identify and define the problem, then work towards solutions at a series of workshops. The goal was to identify strategies for a regional, science-based approach to shellfish management that facilitates shellfish aquaculture commerce while minimizing health risks to cultured and wild populations - in other words, to seek improvements to the present regulatory paradigm that would reduce and minimize impediments to commerce while maintaining biosecurity of the industry. Here we present the findings from three successive workshops during which representatives from industry and the East Coast regulatory and pathology/academic communities, joined by collaborators from the USDA APHIS Veterinary Services and USDA Agricultural Research Service and NOAA Sea Grant met to (1) identify obstacles to effective regional molluscan aquaculture health management and (2) characterize potential solutions from their respective perspectives. Obstacles identified included uncertain pathogen distributions, levels of pathogen presence that exceed acceptable risk, limited structures to coordinate regulations and diagnostic services, and the need to reduce health evaluation costs and time. Communication structures, 
decision support services, shared databases, and mechanisms to direct research were some of the elements considered key to effective regional solutions.

EFFECT OF INTERTIDAL EXPOSURE ON VIBRIO PARAHAEMOLYTICUS LEVELS IN OYSTERS CULTIVATED IN DELAWARE BAY, NEW JERSEY, USA

Lisa Calvo, Tal Ben-Horin, David Bushek

Haskin Shellfish Research Laboratory, Rutgers University, 6959 Miller Avenue, Port Norris, NJ, 08349, USA

Oyster farms in New Jersey are concentrated on the extensive intertidal sand flats of the lower Delaware Bay where they are exposed twice daily during low tide. Previous studies from the Pacific Northwest indicate that intertidal exposure accelerates the proliferation of Vibrios, increasing the risk to human health. We conducted a preliminary study to test whether this result applies to mid-Atlantic intertidal environments. Oysters were collected from subtidal and intertidal rack and bag grow-out systems monthly from June through August 2014. Samples were collected at the initial exposure of intertidal oysters on the receding tide, and then at three and 24 hours following this initial exposure. Total and pathogenic Vp levels were enumerated using a most-probable number quantitative PCR assay with probes targeting the thermolabile direct hemolysin $(t / h)$ and thermostable direct hemolysin $(t d h)$ genes associated with pathogenicity. Observed Vp densities $( \pm 95 \% \mathrm{CI})$ ranged from $19(5-68)$ to $1,100(260-4,700) \mathrm{CFU} / \mathrm{g}$ for total $\mathrm{Vp}, 0$ to $11(3-43) \mathrm{CFU} / \mathrm{g}$ for $t r h$, and 0 to $459(100-2,100)$ $\mathrm{CFU} / \mathrm{g}$ for $t d h$. A significant difference between levels of total and pathogenic Vp between subtidal and intertidal oysters was not seen, nor was there a significant increase in Vibrio burdens over the time course of low-tide exposure. This initial result suggests that the relationship between grow-out conditions and vibrio levels in oysters is not as straightforward as previously thought, and highlights the need for locally relevant aquaculture practices to minimize the risk of Vibrio illness.

THE EXTRACTION OF NUTRIENTS FROM A DANISH FISH FARM (ONCORHYNCHUS MYKISS) BY MUSSELS (MYTILUS EDULIS) AND SUGAR KELP (LAMINARIA SACCHARINA): INTEGRATED MULTI-TROPHIC AQUACULTURE

Jonathan Carl' ${ }^{1}$, Per Andersen', Per Dolmer ${ }^{1}$, Ditte Tørring ${ }^{1}$, Heidi Timm ${ }^{1}$, Mathilde Pedersen ${ }^{1}$, Michael Larsen ${ }^{1}$, Anders Pedersen ${ }^{2}$, Marlene Mølgaard ${ }^{2}$, Theis Boderskov ${ }^{2}$, Peter Schmedes ${ }^{2}$, Susan Holdt $^{3}$, Goncalo Marinho ${ }^{3}$, Lisbeth Plessner ${ }^{4}$

${ }^{1}$ Orbicon, Jens Juuls Vej 18, 8260 Viby, Denmark

${ }^{2}$ Hjarnø Aquaculture A/S Snaptunvej 57b, 7130 Juelsminde, Denmark
${ }^{3}$ National Food Institute Technical University of Denmark Søltofts Plads Building 221, 2800 Kgs. Lyngby, Denmark

${ }^{4}$ Danish Aquaculture, Vejlsøvej 51, 8600 Silkeborg, Denmark

A large scale IMTA production of fish, mussels and sugar kelp is underway in the Danish Kattegat outside a Danish Fjord (Horsens Fjord). The aim is to eventually produce 2105 tons of rainbow trout while removing an equal amount of nitrogen (88 tons) that will be released into the environment by producing and harvesting up to 7500 tons of mussels at 3 sites. Nutrient extraction will be supplemented by the production and harvest of sugar kelp from up to 70 kilometers of lines in a 100 hectare production area. Mussels are produced on smart farm units and sugar kelp is produced on droppers and long-lines. Impacts to the environment were modelled and will be presented. There can be considerable seasonal differences in the nitrogen content of mussels and sugar kelp, their growth in size and total biomass, predatory pressures, and interests in their use. These parameters dictate the decisions of when to harvest mussels and sugar kelp according to environmental and economic feasibility. Results indicate the potential for removing the same amount of nitrogen released into environment from full-scale production of fish by mussel and sugar kelp production is possible, but predation by eider ducks and starfish settling directly on the nets create challenges to mussel survival that need to be overcome to optimise and solidify the IMTA concept in Danish offshore waters.

DECLINE OF AMERICAN LOBSTER ABUNDANCE IN BUZZARDS BAY, MASSACHUSETTS BETWEEN 2005-2006 AND 2013-2014

\section{Kyle Cassidy, Kevin Stokesbury}

University of Massachusetts, Department of Fisheries Oceanography, School for Marine Sciences and Technology, 200 Mill Road, Suite 325, Fairhaven, MA, 02719, USA

While American lobster (Homarus americanus) landings in the Gulf of Maine have increased, the landings in Southern New England have declined over the past decade. In 2005-2006, 13 sites were examined in Buzzards Bay, and the number of lobster per $\mathrm{m}^{2}$ was estimated using a ventless trap survey and tagging experiment. Here we repeat those estimates using similar techniques. We examined the lobster density at the same locations using the same ventless trap and tagging design during the same months of 2013-2014. The abundance at each site was statistically compared between the two time periods. We saw a large decline in the majority of sites surveyed. Decreasing lobster catch per unit effort was correlated with increasing water temperature. Lobsters in southern New England are near the threshold of their optimal temperature limit and as sea temperature increases we expect their distribution to shift towards deeper cooler water, which was supported by several recaptured lobsters outside of the Buzzards Bay area. 
SENSORY MOTOR INTEGRATION OF GILL LATERAL CILIA ACTIVITY IN THE BIVALVE MOLLUSC, CRASSOSTREA VIRGINICA

\section{Edward J. Catapane, Margaret A. Carroll}

Medgar Evers College, 1638 Bedford Avenue, Brooklyn, NY, 11225, USA

Most bivalves that have been studied have gill lateral cells that are innervated by serotonergic and dopaminergic nerves from their ganglia. While the motor aspects of this control have been well described, the sensory side has not. We found that Crassostrea virginica can adjust gill cilia beating rates in response to sensory stimulations to the mantle rim. Detaching the mantle rim or transecting the branchial nerve prevented these responses. $C$. virginica were able to sense and adjust gill cilia beating rates in response to dangerous substances such as crab extract and other sensory cues such as the presence of food when applied to the mantle rim. Pharmacological, biochemical and immunohistochemical studies indicate that histamine is involved as a putative sensory neurotransmitter at the sensory tentacles of the mantle rim. We also found evidence for the presence of histamine $\mathrm{H} 2$ receptors in the sensory tentacles and that histamine also is involved in contraction of muscles of the gill interfilamental junction, which are involved in water flow across the gill. The study further demonstrates a sensory-motor integration of beating of gill lateral cell cilia that involves the sensory mantle rim and the visceral ganglia, and suggests that histamine is a putative sensory neurotransmitter in mantle receptor cells that synapses with afferents going to the visceral ganglia where signals are integrated resulting in a motor response to the gill lateral cells.

\section{CHARACTERIZING NORTHERN ABALONE POPULA- TIONS ACROSS A BROAD GEOGRAPHIC RANGE: PERSPECTIVES ON ENDANGERED LISTING CONSID- ERATION}

Cynthia Catton $^{1}$, Joanne Lessard ${ }^{2}$, Laura Rogers-Bennett ${ }^{3}$

${ }^{1}$ California Department of Fish and Wildlife, Bodega Marine Laboratory, 2099 Westside Road, Bodega Bay, CA, 94923, USA

${ }^{2}$ Pacific Biological Station, Fisheries and Oceans Canada, 3190 Hammond Bay Road, Nanaimo, British Columbia, V9T 6N7, Canada

${ }^{3}$ University of California Davis, Bodega Marine Lab, P.O. Box 247, Bodega Bay, CA, 94923, USA

Northern abalone (Haliotis kamtschatkana) is being considered for listing on the US Endangered Species List, based on severe population declines from Alaska to California since the 1970s. The declines may be due to a combination of stressors, including overfishing and limited reproduction in low-density areas. The particular impacts, and the potential for future population growth, differ across the geographic range. These differences were investigated by characterizing populations in southern British Columbia, northern Washington, and California (northern and southern). Population densities, aggregation characteristics, and size-frequency distributions were compared to determine the relative health of the populations across this broad geographic range. Populations in northern California were found to be the healthiest, with increasing densities since 2006, and a broad spectrum size range. The southern California population also showed a broad size distribution despite an overall lower estimated density. Southern British Columbia populations showed evidence of high adult mortality, possibly due to poaching, whereas the northern Washington population showed evidence of reproductive failure. These results reveal that density declines have occurred only in the northern extent of the species range, but that recovery may be possible with actions limiting poaching in British Columbia and enhancing reproduction in Washington.

DIRECT DEPOSITION OF CRYSTALLINE ARAGONITE IN THE CONTROLLED BIOMINERALIZATION OF THE CALCAREOUS TUBEWORM

Vera B. S. Chan ${ }^{1}$, Takashi Toyofuku ${ }^{2}$, George Wetzel ${ }^{3}$, Laxmikant Saraf $^{3}$, Vegatensen Thiyagarajan ${ }^{1}$, Andrew S. Mount ${ }^{4}$

${ }^{1}$ The University of Hong Kong (HKU), Swire Institute of Marine Sciences and School of Biological Sciences, Pokfulam, Hong Kong, China

${ }^{2}$ Department of Marine Biodiversity Research, Japan Agency for Marine-Earth Science and Technology (JAMSTEC), 2-15 Natsushima-cho, Yokosuka, 237-0061, Japan

${ }^{3}$ Clemson University, Advanced Material Research Laboratory (AMRL), Clemson, SC, 29634, USA

${ }^{4}$ Clemson University, Department of Biological Sciences, Clemson, SC, 29634, USA

The serpulid tubeworms are common warm water biofouling organisms. They show exquisite controls in a cellular environment during mineralization. At larval metamorphosis, the actively calcifying region, i.e. the thoracic region between the collars, showed a high $\mathrm{pH}$ value above 8.5 and elevated calcium ion levels. Our results indicate calcification occurs internally within a controlled compartment where proton efflux and calcium ion influx are observed. The use of unpolished biological samples, were analyzed on the scanning electron microscope (SEM) equipped with low voltage and nondestructive Electron backscatter diffraction (EBSD) approach. The result demonstrated direct formation of aragonite. Furthermore, in situ focused ion beam (FIB) lift-out technique, the Transmission electron microscopy (TEM) specimen prepared for the calcified region showed a distinctive diffraction pattern that suggests direct deposition of crystalline aragonite. There is no evidence to suggest the presence of amorphous calcium carbonate (ACC) in the above observation. A biomineralization model of proton efflux and calcium ion influx leading to the internal aragonite formation is proposed. 
CURRENT AND FUTURE FRESHWATER FLOW CONTROL OF OLYMPIA OYSTER POPULATION DEMOGRAPHY IN THE SAN FRANCISCO ESTUARY

Andrew L. Chang ${ }^{1}$, Anna K. Deck ${ }^{2,3}$, Preston D. Malm ${ }^{2}$, Sarikka Attoe $^{2}$, Karissa Willits ${ }^{2}$, Lindsay J. Sullivan ${ }^{4}$, Steven G. Morgan ${ }^{2}$

${ }^{1}$ Smithsonian Environmental Research Center, 3152 Paradise Dr, Tiburon, CA, 94920, USA

${ }^{2}$ University of California Davis, Bodega Marine Laboratory, PO Box 247, Bodega Bay, CA, 94923, USA

${ }^{3}$ San Francisco Bay National Estuarine Research Reserve, 3152 Paradise Dr, Tiburon, CA, 94920, USA

${ }^{4}$ San Francisco State University, Romberg Tiburon Center, 3152 Paradise Dr, Tiburon, CA, 94920, USA

The Olympia oyster, Ostrea lurida, is a target of conservation and restoration efforts in numerous Pacific estuaries, including San Francisco Estuary. A better understanding of population fluctuations could significantly aid restoration outcomes and improve resilience to future climatic changes. Oyster populations in the San Francisco Estuary appear to be controlled to a significant extent by interannual and seasonal freshwater flow variation. The effects of these physical environmental changes on different oyster life stages from 2009 - 2011 were quantified using extensive field data spanning a wide range of salinity conditions to parameterize matrix models to look at demographic consequences for oyster populations. The population-level impacts of past and projected future freshwater flow regimes were then evaluated. Population levels are projected to vary at different tempos and magnitudes in the northern and central regions of the estuary, compared to the South Bay. Great fluctuations in North Bay population densities occurred as high settlement was balanced against the inability of local populations to survive wetter winters. In contrast, South Bay populations had steady demographic rates during the study period, possibly making this area an important buffer against more moderate fluctuations in freshwater flow on a decadal scale. On longer time scales, however, South Bay populations also face significant mortality risk, as the geomorphology of the estuary produces increased water residence time in that region, so low salinity events can last significantly longer. When freshwater flow enters the South Bay at high enough levels, we project extensive mortality and possibly longer population recovery times.

THE ASIAN CLAM (CORBICULA FLUMINEA): SEASONAL FILTRATION RATES AND POPULATION DYNAMICS IN TWO TRIBUTARIES OF THE DELAWARE RIVER Kurt Cheng $^{1,2}$, Danielle Kreeger ${ }^{1,2}$

${ }^{1}$ Drexel University, Department of Biodiversity, Earth and Environmental Sciences, 3245 Chestnut Street, Philadelphia, PA, 19104, USA

${ }^{2}$ Partnership for the Delaware Estuary, 110 South Poplar Street, Suite 202, Wilmington, DE, 19801, USA
The Asian clam, Corbicula fluminea, is an exotic freshwater bivalve that was first introduced to the United States in the early 1930s and was first documented in the Delaware River in the 1970s. Corbicula is a filter feeding bivalve that may potentially impact water quality through a reduction of turbidity and removal of particulate pollutants and pathogens. In freshwater areas of the Delaware River basin Corbicula often represents the majority of infaunal biomass. Despite their prevalence in the system, the feeding behavior and population dynamics of Asian clams are not well understood. Seasonal filtration rates and representative population abundances were assessed and contrasted between Asian clam populations in the Cooper River, NJ and the Red Clay Creek, DE. A range of sizes of clams from both streams were fed on natural seston during spring, summer and fall, and their seasonal filtration rates were calculated from measured clearance rates and seston concentrations. Seasonal population surveys examined the shifts in spatial abundance and sizes of adults and juveniles in both populations. Filtration rates and population data were paired to estimate the potential population-level removal of total suspended solids. Preliminary analyses suggest similarities in weight-specific filtration rates across seasons and among streams and differences in clam-mediated ecosystem services between the representative Coastal Plain stream (Cooper) and the Piedmont stream (Red Clay) mainly due to differences in population demographics. These data will assist water quality managers to assess the role of dominant biota in governing water quality in the Delaware River Basin.

ITS AND 18S RDNA SEQUENCE POLYMORPHISM OF PERKINSUS OLSENI ISOLATES FROM MANILA CLAM RUDITAPES PHILIPPINARUM IN KOREAN WATER

Young Ghan Cho, Hyun-Sil Kang, Hyun-Ki Hong, Kwang-Sik Choi

School of Marine Biomedical Science (BK21 PLUS), Jeju National University, 102 Jejudaehakno, Jeju 690-756, Republic of Korea

Perkinsosis in Ruditapes philippinarum has been reported from Korea, Japan and China for the past decades and mass mortalities of Manila clam in Korea have been associated with the extremely high levels of Perkinsus olseni. In the present study, we isolated different populations of $P$. olseni from Manila clams and cultured in vitro to compare genetic affinity of the Perkinsus isolates. For the culture, each of 40 clams was collected from 11 sites located on the East, west, south coasts and Jeju Island. RFTM indicated that $P$. olseni infection intensities and the prevalence in the clam populations varied $0-100 \%$ and $0-4.87 \times 10^{6} \pm 8.43 \times 10^{5}$ cells $/ \mathrm{g}$ gill tissue weight, respectively. Twenty three clones of the $P$. olseni were continuously cultured from 6 of 11 sites, and amplified. ITS and $18 \mathrm{~S}$ rDNA sequences of $P$. olseni isolates showed $99.8-100 \%$ and $99.9-100 \%$ similarity to those of $P$. olseni $(=P$. atlanticus) reported in Asian and European waters. Both the ITS and 18S 
rDNA sequences cloned from 23 isolates of the $P$. olseni were identified the nucleotide polymorphism with three types of the variant. Further phylogenetic analysis of the ITS and 18S sequences revealed that $P$. olseni isolates could be grouped into two clades within a well-characterized $P$. olseni clade.

EFFECTS OF DISPERSED AND EMULSIFIED OIL ON MOLTING, ECDYSONE AND ECR/RXR COMPLEX IN THE GRASS SHRIMP AND THE BLUE CRAB

J. Sook Chung ${ }^{1}$, Karrie Bulski ${ }^{2}$, Anna N. Walker ${ }^{3}$, Richard F. Lee ${ }^{2}$

${ }^{1}$ Institute of Marine and Environmental Technology, University of Maryland Center for Environmental Science, 701 E Pratt Street, Baltimore MD, 21202, USA

${ }^{2}$ Skidway Institute of Oceanography, Savannah, GA, 31406, USA

${ }^{3}$ Mercer University School of Medicine, Macon, GA, 31207, USA

It has been known that the exposure to crude oil inhibits molting in crustaceans. We hypothesized that such inhibition in molting process is possibly due to the change in the levels of ecdysone and its receptor (Ecdysone receptor $=\mathrm{EcR} /$ Retinoid-X receptor $=\mathrm{RXR}$ ) complex. Grass shrimp or blue crabs were exposed to sediment or food containing water-oil emulsions of oil, followed by assays for ecdysone and EcR/RXR complex in the $\mathrm{Y}$-organs and hepatopancreas, as well as morphological studies. Blue crabs fed food containing emulsified oil had distended hemocytes with eosinophilic material composed of glycoproteins. Grass shrimp embryos were exposed to dispersed oil (dispersants added to crude oil to produce dispersed oil droplets), followed by assays for ecdysone and the EcR/RXR complex. After exposure to dispersed oil the late embryo stages showed abnormalities with respect to molting and hatching from the egg sacs. There was evidence of the effects of both emulsified and dispersed oil on ecdysone and the EcR/RXR complex.

CLAMS ON ACID: EXPERIMENTAL EFFECTS OF SEDIMENT ACIDIFICATION ON BURROWING BEHAVIOUR AND DISPERSAL OF JUVENILE SOFT-SHELL CLAMS Jeff C. Clements, Krystal D. Woodard, Heather L. Hunt

Department of Biology, University of New Brunswick Saint John, 100 Tucker Park Road, P.O. Box 5050, Saint John, NB, E2L4L5, Canada

Since the Industrial Revolution, oceanic $\mathrm{pH}$ has fallen approximately 0.1 units and is projected to drop another 0.3 0.5 units by 2100 , resulting in negative implications for many marine organisms. However, coastal areas already experience conditions more acidic than the open ocean, often with drastic fluctuations in carbonate chemistry both spatially and temporally. Here we report the implications of coastal sediment acidification on the burrowing behavior and dispersal of juvenile soft-shell clams in the lab and the field. Baseline measurements of sediment carbonate geochemistry were recorded from four mudflats in the Bay of Fundy. In the lab, clam burrowing was tested in response to sediment collected from the Bay of Fundy over a naturally varying range of carbonate geochemical conditions. A 24-h field experiment was conducted to test the effect of acidification by $\mathrm{CO}_{2}$ addition on the dispersal of juvenile clams under natural water flow conditions in a Bay of Fundy mudflat. The field experiment also explored the potential of three sediment buffers to enhance clam recruitment. Field measurements suggested that sediment carbonate geochemistry was highly variable on short temporal scales, but relatively stable spatially. In the lab, naturallyvarying sediment carbonate geochemistry affected burrowing. The field experiment revealed an effect of acidification on clam dispersal, with more clams dispersing under more acidic conditions, while sediment buffering enhanced clam recruitment and suggested that variability in carbonate geochemistry may increase dispersal. Ultimately, this study enhances our understanding of the effects of sediment acidification on juvenile bivalves and the behavioral implications of ocean acidification.

THE DIRTY SECRET ON BURROWING SHRIMP GROWTH: VERIFICATION OF TWO ALTERNATIVE METHODS OF AGE DETERMINATION IN THE BURROWING SHRIMP NEOTRYPAEA CALIFORNIENSIS

Natalie Coleman $^{1}$, Katelyn Bosley ${ }^{2}$, Brett Dumbauld ${ }^{3}$

${ }^{1}$ Oregon State University, Department of Integrated Biology, Corvallis, Oregon, USA

${ }^{2}$ Oregon State University, Department of Fisheries and Wildlife, Newport, Oregon, USA

${ }^{3}$ USDA-ARS, Newport, Oregon, USA

The burrowing shrimp Neotrypaea californiensis is an important ecosystem engineer inhabiting estuaries along the Pacific Northwest coast. The burrowing action of these shrimp is a threat to oyster aquaculture, especially in the state of Washington where topical pesticides have been sprayed to control shrimp populations. More information is needed about this species, including a viable aging method to contribute to an integrated pest management plan for these shrimp. Obtaining accurate age estimates for crustaceans is difficult because they molt their hard parts and don't retain evidence of age over a lifespan. This study explored verification of two methods, lipofuscin analysis and gastric mill rings. Each method was 
used on known-age shrimp grown in mesocosms since recruitment and shrimp from surveys conducted in Yaquina Bay, Oregon and Willapa Bay, Washington. Lipofuscin values of known-age shrimp were similar while size varied, verifying that this method is useful in the direct aging of crustaceans. The number of rings correlated more directly with growth than with lipofuscin, suggesting that they might not be a direct measure of linear age but rather metabolic age, which is likely more affected by environmental factors. Size varied across age classes, which indicates size is not a reliable indicator of age in $N$. californiensis. Mean lipofuscin index from mesocosm shrimp was used to assign age classes to shrimp from population surveys to reveal age classes. The ability to create an age structure using lipofuscin-based methods should enable creation of more accurate population models and provide valuable information on burrowing shrimp growth rates which appear to vary significantly.

\section{CHARACTERIZATION OF PHENOTYPIC VARIATION FOR DERMO RESISTANCE AMONG SELECTIVELY-BRED FAMILIES OF THE EASTERN OYSTER, CRASSOSTREA VIRGINICA}

Ryan J. Corbett ${ }^{1}$, Marta Gomez-Chiarri ${ }^{1}$, Jessica Moss Small ${ }^{2}$, Standish K. Allen Jr. ${ }^{2}$, Dina A. Proestou ${ }^{3}$

${ }^{1}$ University of Rhode Island, Department of Fisheries, Animal and Veterinary Science, 170 CBLS, 120 Flagg Road, Kingston, RI 02881, USA

${ }^{2}$ Virginia Institute of Marine Science, College of William \& Mary, Rt. 1208 Greate Road, Gloucester Point, VA 23062, USA

${ }^{3}$ USDA, Agricultural Research Service, NEA, NCWMAC, Shellfish Genetics Lab, 469 CBLS, 120 Flagg Road, Kingston, RI 02881, USA

Dermo disease impacts nearly every region where the eastern oyster, Crassostrea virginica, is cultured. Breeding for resistance has had some success, but the amount of phenotypic variation in Dermo resistance among selectively bred families is largely unknown. Twenty-three $C$. virginica families exposed to the Dermo-causing parasite Perkinsus marinus in a laboratory challenge were used to quantify the extent of phenotypic variation in resistance. Oysters $(\mathrm{N}=48)$ from each family were subdivided into challenged and control groups. Challenged oysters were notched and injected with $5 \times 10^{6}$ cultured Perkinsus cells per gram wet tissue weight while control oysters were injected with sterile salt solution. The two groups were maintained in separate flowing static systems at $25^{\circ} \mathrm{C}$ and $25 \mathrm{ppt}$ and mortalities were monitored each day for 42 days. Soft tissues were sampled from moribund oysters during the experiment and survivors at the end of the experiment to assess Perkinsus load. Mortality among challenged oysters, as well as the difference in cumulative mortality between the two treatments, varied by family
(42-100\% and 4-54\% respectively). Assessments of Dermo infection on a subset of samples confirm that the observed mortality in the challenged animals was largely Dermo-driven while that of the controls was infection-independent. Death date and infection intensity, combined as a single "resistance index," provides a quantitative measure of phenotype. A more expansive evaluation of parasite load in a larger population of challenged animals is underway and will enable a more comprehensive assessment of phenotypic variation for Dermo-resistance among the families tested.

\section{RESTORED OYSTER REEF DENITRIFICATION - EXPER- IMENTAL CONSIDERATIONS AND BIOGEOCHEMICAL MECHANISMS}

Jeffrey Cornwell ${ }^{1}$, Michael Owens ${ }^{1}$, Zachary Nickerson ${ }^{1}$, Lisa Kellogg ${ }^{2}$

${ }^{1}$ UMCES Horn Point Laboratory, P.O. Box 775, Cambridge, MD, 21613, USA

${ }^{2}$ Virginia Institute of Marine Science, Rt. 1208 Greate Road, Gloucester Point, VA, 23062, USA

The removal of nitrogen from aquatic ecosystems by bivalves results from processes such as nitrogen burial, microbial denitrification and allied processes, and harvest. In a non-harvested restored oyster reef environment, denitrification-the conversion of fixed nitrogen to gaseous dinitrogen-may be a key pathway for nitrogen removal. Recent studies, and the hopeful extrapolation of these studies to whole ecosystems, suggest that spatially extensive oyster reef communities could provide a quantitatively important water quality benefit in nutrient-impacted estuaries. Quantification of oyster community denitrification benefits requires 1) denitrification rates using defensible methods and 2) an understanding of environmental controls on denitrification, allowing a reasonable extrapolation to locations in which these relatively costly measurements are not carried out. In this talk, the pros and cons of our current approach to measuring reef denitrification are described and data discussed which suggest sediment denitrification may not be a major biogeochemical pathway. Comparison of denitrification and metabolism in sediments from Harris Creek, MD to newly-established oyster reef communities illustrate a rapid, system wide effect on biogeochemical rate processes.

METABOLIC SIGNATURES OF THE HERPESVIRUS OSHV-1 $\mu$ VAR IN THE OYSTER: THE WARBURG EFFECT Charlotte Corporeau, Lizenn Delisle, Yanouk Epelboin, Claudie Quéré, Fabrice Pernet

Ifremer, Laboratoire des sciences de l'Environnement Marin (UMR 6539, LEMAR), 29280 Plouzané, France

Since 2008, mass mortalities of juvenile Crassostrea gigas have notably affected all rearing sites along coasts of France when 
seawater temperature exceeds $16^{\circ} \mathrm{C}$ (EFSA, 2010). Results of diagnostic tests show that they are associated with the detection of a particular genotype of the ostreid herpesvirus 1 (OsHV-1) named $\mu \operatorname{Var}$ (Segarra et al., 2010). The goal is to identify metabolic pathways involved in the infection of oyster by OsHV-1 $\mu$ Var. Eight month-old Crassostrea gigas were anesthetized and injected in the muscle with high load (challenged oyster) or low load (control oyster) inoculum of OsHV-1 $\mu$ Var. At two days post-injection, quantity of OsHV-1 DNA in challenged oysters was 10.000 times higher than in that of control oysters. Using a two-dimensional (2D) proteomic approach, we analysed 10 proteomes obtained from individuals that exhibited contrasted infection status, as measured by their individual OsHV-1 DNA level. Twenty-five differentially expressed proteins were identified in challenged oysters showing an increased glycolysis, among them accumulation of the porin VDAC, which reflects a "Warburg effect" (Warburg, 1956) in infected oysters. The Warburg effect is an atypical metabolism that favours OsHV-1 $\mu$ Var by providing cellular energy and building blocks during viral genome replication in oyster, and was initially reported in cancer cells and more recently in shrimp infected with virus (Chen et al., 2011). Further researches are currently on-going to investigate how environmental factors could control the Warburg effect in Crassostrea gigas to delay or protect from disease mortality risk.

OLYMPIA OYSTER CULTIVATION FOR RESTORATION PART I: BREEDING AND HATCHERY PROPAGATION TECHNIQUES

Ryan Crim ${ }^{1,2}$, Brian Allen ${ }^{1}$, Alex Karpoff ${ }^{1,2}$, Stuart Ryan ${ }^{1,2}$, Joth Davis $^{1,2}$, Brent Vadopalas ${ }^{3}$

${ }^{1}$ Puget Sound Restoration Fund, 382 Wyatt Way NE, Bainbridge Island, WA, 98110, USA

${ }^{2}$ Kenneth K. Chew Center for Shellfish Research and Restoration, USA

${ }^{3}$ University of Washington, School of Aquatic and Fisheries Science, 1122 NE Boat Street, Seattle, WA, 98105, USA

In the Puget Sound, Olympia oyster (Ostrea lurida) core populations occupy less than $4 \%$ of their historic area. Active restoration efforts are underway to restore 100 acres of Olympia oyster bed habitat at 19 historic sites within the Puget Sound. While Olympia oysters exist throughout the historic distribution in Puget Sound, they are generally a rare component of the biota. In some locations remnant aggregations may be reproducing, but abundances are too small to produce larval supplies to the system sufficient to build oyster bed habitat. In such places, hatchery propagation of oyster seed is one tool we use to re-build oyster populations. The Puget Sound Restoration Fund has been working with Washington Department of Fish and
Wildlife shellfish biologists and population geneticists at the University of Washington to develop propagation techniques that produce Olympia oyster seed that resemble, as much as possible, a wild population. Here I will discuss our best practices to date as they pertain to broodstock selection and conditioning, breeding design, larval culture and setting techniques. There is still much to learn about Olympia oyster culture and our everchanging methodologies are constantly being updated to reflect the best data available.

GEOGRAPHIC DISTRIBUTION AND QUANTIFICATION OF ABALONE WITHERING SYNDROME (WS-RLO) VIA SEAWATER SURVEYS FROM WILD AND FARMED POPULATIONS ALONG THE CALIFORNIA COAST

Lisa M. Crosson ${ }^{1}$, Glenn R. VanBlaricom ${ }^{1,2}$, Samuel J. White ${ }^{1}$, Carolyn S. Friedman ${ }^{1}$

${ }^{1}$ University of Washington, School of Aquatic and Fishery Sciences, Box 355020, Seattle, WA, 98195, USA

${ }^{2}$ US Geological Survey, Washington Cooperative Fish and Wildlife Research Unit, University of Washington, Box 355020, Seattle, WA, 98195, USA

Wild black abalone populations and red abalone farms along the California coast and Channel Islands were surveyed in the summers of 2010, 2011 and 2013 for the presence of withering syndrome (WS-RLO). Seawater samples were collected from each wild site $(\mathrm{n}=8)$ and nearshore at 0,100 and $500 \mathrm{~m}$ above and below abalone farm outfalls $(n=5)$. Water samples were filtered and preserved for subsequent DNA extractions and quantitative PCR analyses. To date, wild seawater samples from Big Sur to San Diego, CA, including San Nicolas Island, tested positive for the presence of WS-RLO DNA ranging from 10 to 1,000 copies per liter. Effluent from abalone farms also tested positive for WS-RLO DNA and ranged from 1,000 to 100,000 copies per liter directly adjacent to outflows. Farms release large volumes of seawater per day $\left(10^{6}\right.$ gallons) suggesting a high potential for some facilities to act as point sources of the pathogen to nearby wild abalone populations as well as serving as sources of WS-RLO for the farms themselves. When extrapolated, WS-RLO DNA released from farm effluent can be upwards of 100 billion copies per liter per day. While this presents concern for potential pathogen pollution, it is important to note DNA-based PCR assays do not detect viable pathogen or infection and serve only as a proxy for exposure. There was also a strong dilution factor as WS-RLO DNA copy numbers dropped substantially at 100 and $500 \mathrm{~m}$ away from farm outflows. Additional experiments including deployment of sentinel abalone at wild and farm sites to assess transmission dynamics and determination of WS-RLO viability in seawater are currently underway. 
MODELING THE POSSIBLE EFFECTS OF GLOBAL WARMING IN STOCKS OF PANOPEA GLOBOSA FROM GULF OF CALIFORNIA

Rolando Cruz-Vásquez ${ }^{1}$, Sergio G. Castillo-Vargasmachuca ${ }^{1}$, E. Alberto Aragón-Noriega ${ }^{2}$

${ }^{1}$ Posgrado en Ciencias Biológico Agropecuarias, Universidad Autónoma de Nayarit, Carretera Tepic-Compostela Km 9, Xalisco, Nayarit, 63780, México

${ }^{2}$ Centro de Investigaciones Biológicas del Noroeste, Unidad Sonora, Km 2.35 Camino al Tular, Estero de Bacochibampo, Guaymas, Sonora, 85454, México

This paper describes the most favorable habitat of Cortes geoduck (Panopea globosa) in the Gulf of California, using the maximum entropy model (MaxEnt), in which 12 environmental parameters were used. The sites with presence serve as sampling points, geographic region of interest is the space where the distribution is defined and the features are the environmental variables. The sea temperature will increase, globally, $1-3{ }^{\circ} \mathrm{C}$ as a result of global warming. With a simple linear regression analysis and taking as a factor the year, the annual rate of thermal change was estimated. The generated information was included in a geographic information system and interpolated using the Geostatistical Analyst extension of ArcMap 9.3 program to build-up maps prospect trends temperature rise in 2050. In order to evaluate if the increased sea temperature will affect the P. globosa distribution, the generated maps were incorporated to the MaxEnt. The distribution of $P$. globosa is slightly more restricted to the North of the Gulf of California and disappears in the portion north of Sinaloa. In the upper Gulf there is an increase in the probability of occurrence mainly in the Gulf of Santa Clara and San Felipe ( 0.80 and 0.60 respectively), sites of greater probability of occurrence in Sonora is slightly reduced toward the coast; in Santa Rosalía and Isla San Marcos B.C.S. likely decreases of 0.70 to 0.04 . These results should be taken with caution since the other variables included in the model remained constant which can cause incomplete results.

\section{SHELLFISH TRANSFERS AS A POTENTIAL VECTOR FOR EUROPEAN GREEN CRABS (CARCINUS MAENAS) AND OTHER NON-NATIVE SPECIES}

Lyanne J.F. Curtis, Daniel L. Curtis, Haley Matkin, Matthew Thompson, Francis Choi, Paul Callow, Graham E. Gillespie, Thomas W. Therriault, Christopher M. Pearce

Pacific Biological Station, Fisheries and Oceans Canada, 3190

Hammond Bay Road, Nanaimo, British Columbia, V9T 6N7, Canada

The spread of non-indigenous species (NIS), such as European green crabs (Carcinus maenas), via human mediated vectors is a global concern. The transfer of cultured shellfish is thought to be one of the potential vectors for this spread; however, there is little scientific evidence surrounding the potential of transferred shellfish to entrain and transport NIS to new areas. This is particularly relevant to British Columbia given the arrival of green crabs to Vancouver Island in the late 1990s and the continued growth of shellfish aquaculture in the province. The potential for NIS entrainment on shellfish was investigated through a two-year experimental field study carried out along the west coast of Vancouver Island in waters that were known to be infested with green crabs. A short-term study was also conducted examining shellfish collected from processing facilities or directly from growers. The entrainment potential of cultured shellfish was confirmed in the field study for green crabs at two different life stages and for four other NIS. Five NIS (three tunicate and two bryozoan species), not including the green crabs, were also found on shellfish that had been collected directly from processors and growers (three tunicate and two bryozoan species). A review of the available literature confirmed that none of the experimentally tested mitigation methods were $100 \%$ effective at removing NIS prior to product transport. Several gaps in current shellfish aquaculture practices were identified and a conceptual framework to reduce the risk of spreading NIS at each stage of the shellfish transfer process was developed.

CALIFORNIA SEA CUCUMBERS (PARASTICHOPUS CALIFORNICUS) IN AQUACULTURE: ASSESSING FEASIBILITY, POTENTIAL ECOLOGICAL INTERACTIONS, AND ENVIRONMENTAL REMEDIATION

Daniel L. Curtis ${ }^{1}$, Christopher M. Pearce ${ }^{1}$, Paul van Dam-Bates ${ }^{2}$, Lindsay C. Orr ${ }^{1,3}$, Nicholas M.T. Duprey ${ }^{1}$, Stephen F. Cross ${ }^{3,4}$, Laura L.E. Cowan ${ }^{2}$

${ }^{1}$ Pacific Biological Station, Fisheries and Oceans Canada, 3190 Hammond Bay Road, Nanaimo, British Columbia, V9T 6N7, Canada

${ }^{2}$ University of Victoria, Department of Mathematics and Statistics, 3800 Finnerty Road, Victoria, British Columbia, V8P 5C2, Canada

${ }^{3}$ University of Victoria, Department of Geography, 3800 Finnerty Road, Victoria, British Columbia, V8P 5C2, Canada

${ }^{4}$ SEA Vision Group Inc., Courtenay, British Columbia, V9N 9N8, Canada

Recent interest in the benthic ranching of California sea cucumbers (Parastichopus californicus) has generated concerns regarding the possible interaction between wild and cultured stocks and the potential environmental impact of farming. To address these concerns and ascertain the feasibility of culturing sea cucumbers at existing shellfish farms, a series of laboratory- and field-based experiments were conducted. Laboratory studies showed that when presented with low total organic matter (TOM) sediment, cucumbers display slower, more directed move- 
ment. With high TOM sediment, movements were more random. This suggests that aquaculture sites may retain wild cucumbers if they happen upon one of these high TOM areas, but both wild and cultured cucumbers will eventually stray, resulting in mixing if the two stocks are not segregated. In the field, at an existing deep-water Pacific oyster (Crassostrea gigas) farm, sea cucumbers were present at much higher densities than the surrounding area, but displayed seasonal reductions in density of approximately $50 \%$ during winter months, suggesting that animals are migrating away from the aquaculture site. Sea cucumbers displayed good growth and survival when cultured in benthic cages either at or away from the oyster farm. There was no clear effect of location on growth; however, in both cases growth was dependent on stocking density. Laboratory results have shown that sea cucumbers will actively feed on, and have high absorption efficiencies for, aquaculture waste products, suggesting that culturing sea cucumbers beneath existing aquaculture sites may help to ameliorate some of the increased organic loading in these areas.

CAN SUBTIDAL BAY CLAMS SERVE AS SOURCE POPULATIONS FOR THE INTERTIDAL? A PRELIMINARY EVALUATION OF THE SUBTIDAL "SPAWNING STOCK HYPOTHESIS" IN TWO OREGON ESTUARIES

Anthony F. D'Andrea, Elizabeth A. Perotti, Stacy Galleher, Cinamon L. Moffett, Stacy A. Strickland

Oregon Department of Fish and Wildlife, 2040 SE Marine Science Drive, Newport, OR, 97365, USA

Spawning stocks are populations that are subject to little or no human harvest. Subtidal habitats, which are protected from many intertidal predators and are always submerged, are often assumed to harbor large bay clam populations that serve as spawning stock for intertidal populations. The Shellfish and Estuarine Habitat Assessment of Coastal Oregon (SEACOR) project conducted extensive surveys of bay clam populations in subtidal and intertidal habitats of two Oregon estuaries. Tillamook Bay (2010-2012) is Oregon's second largest outer coast estuary and supports more than $70 \%$ of the state's commercial bay clam fishery. In contrast, Netarts Bay (2013-2014) also serves as an important recreational clamming destination, but is smaller and experiences comparatively small commercial harvest. Using a stratified-random design (tide flat $\mathrm{x}$ tide height), bay clam (Clinocardium nuttallii, Tresus capax, Saxidomus gigantea, Leukoma staminea) population and habitat data were collected for the main intertidal flats and subtidal channels. In Tillamook Bay, subtidal channels supported high densities of all target species except littleneck clams, which were also less abundant in the intertidal than other clams. Cockle and gaper clams were 7-9X more abundant and butter clams were $25 \mathrm{X}$ more abundant in the subtidal than the intertidal. These data support a spawning stock hypothesis in Tillamook Bay. Alterna- tively, the only abundant species in subtidal habitats in Netarts Bay was the cockle, which was $2 \mathrm{X}$ more abundant in the subtidal than the intertidal. However, the Shellfish Preserve may serve as an important intertidal spawning stock population for butter, cockle, and littleneck clams.

\section{PERKINSUS SP. INFECTIONS AND IN VITRO ISOLATES} FROM ANADARA TRAPEZIA MUD ARKS OF QUEENSLAND, AUSTRALIA

Cécile Dang ${ }^{1}$, Christopher F. Dungan ${ }^{2}$, Gail P. Scott ${ }^{3}$, Kimberly S. Reece $^{3}$

${ }^{1}$ The University of Queensland, School of Biological Sciences and Centre for Marine Science, Brisbane, QLD 4072, Australia

${ }^{2}$ Maryland Department of Natural Resources, Cooperative Oxford Laboratory, 904 S. Morris Street, Oxford, MD, 21654, USA

${ }^{3}$ Virginia Institute of Marine Science, College of William \& Mary, P. O. Box 1346, Gloucester Point, VA, 23062, USA

Perkinsus sp. protists infected Anadara trapezia mud ark cockles at six sites in Moreton Bay, Queensland, Australia at prevalences of $4-100 \%$ during 2011 , as determined by surveys using Ray's fluid thioglycollate medium (RFTM) assays. Perkinsus sp. lesions were found among gill and visceral connective tissues in histological samples from several of those cockles, where signet ring Perkinsus sp. trophozoites and proliferating schizont cells were both intensely basophilic, and had eccentric vacuoles. Two Perkinsus sp. isolates were propagated in vitro during August 2013 from gill tissues of a single A. trapezia cockle from Wynnum in Moreton Bay. DNAs from those isolate cells amplified universally by a Perkinsus genus-specific PCR assay, and rDNA-ITS sequences respectively grouped them with $P$. olseni and $P$. chesapeaki in phylogenetic analyses. This is the first report of $P$. chesapeaki in Australia, and the first report of a $P$. chesapeaki in vitro isolate from an Australian mollusc host. Although P. olseni was originally described in 1981 as a pathogen of abalone in South Australia, and has subsequently been identified as a prevalent pathogen of numerous other molluses worldwide, this is the first report of a P. olseni-like in vitro isolate from an Australian mollusc host.

\section{THE EFFECT OF NEUROTRANSMITTERS ON ISOLATED VENTRICLES OF THE GREEN MUSSEL, PERNA VIRIDIS}

\section{Lewis Deaton}

University of Louisiana at Lafayette, Biology Department, Lafayette, LA, 70504, USA

The ventricles were removed from Perna viridis collected from Estero Bay near Bonita Beach, Florida and suspended in 
organ baths containing aerated seawater. The mechanical activity of the preparations was recorded with a force transducer and polygraph (Grass model 7). The addition of 5hydroxytryptamine $(5-\mathrm{HT})$ to the bath resulted in positive ionotropy; the threshold was $10^{-9} \mathrm{M}$. In some preparations, high $\left(10^{-6} \mathrm{M}\right)$ doses of 5-HT induced positive chronotropy. Acetylcholine (Ach) had no effect on the hearts. The molluscan neuropeptide phenylalanyl-leucinyl-arginyl-phenylalanylamide (FLRFamide) inhibited the ventricles with a threshold dose of $10^{-7} \mathrm{M}$. In contrast, paraglutaminyl-aspartyl-prolylleucinyl-arginyl-phenylalanylamide (pQDPFLRFamide) had no effect. The cyclic 3'-5'-adenosinemonophosphate (cAMP) agonist forskolin and hydrogen sulfide and nitric oxide donors also had no effect on the mechanical activity of the hearts. In most, but not all, species of bivalves that have been examined, 5-HT is cardioexcitatory and Ach is cardioinhibitory. The heart of $P$. viridis is unusual in that it is insensitive to Ach and is inhibited by FLRFamide. In bivalves, FLRFamide is generally a cardioexcitatory molecule. The extended neuropeptide pQDPFLRLamide is generally more effective in gastropods than bivalves; this is consistent with the results reported here. The results further suggest that cAMP is not involved in the effects of $5 \mathrm{HT}$.

\section{CARBOHYDRASE ACTIVITY IN THE DIGESTIVE GLANDS OF TWO FRESHWATER MOLLUSCS: POMACEA MACU- LATA AND MARGARITIFERA HEMBELI \\ Lewis Deaton}

University of Louisiana at Lafayette, Biology Department, Lafayette, LA, 70504, USA

Apple snails (Pomacea maculata) and unionid clams (Margaritifera hembeli) were collected from local bayous and farm ponds. Digestive gland tissue was dissected from the animals, homogenized in buffer, and the homogenates were then centrifuged. Aliquots of the supernatant fluid were assayed for cellulose, laminarinase, and amylase activity using 4hydroxybenzhydrazide to detect glucose released by digestion of these three substrates. Controls for glycosylated proteins were included in all assays. Amylase activity was $0.07 \pm 0.07$ $\mathrm{nmol} \mu \mathrm{g}^{-1} \mathrm{hr}^{-1}$ (mean \pm standard deviation, $\mathrm{n}=16$ ) and $0.06 \pm$ $0.04(\mathrm{n}=16)$ in $P$. maculata and $M$. hembeli, respectively. Cellulase activity was $0.04 \pm 0.7(\mathrm{n}=10)$ in $P$. maculata and $0.04 \pm 0.03(\mathrm{n}=7)$ in $M$. hembeli. Laminarinase activity in the snail was $0.09+0.09(\mathrm{n}=10)$ and $0.05+0.04(\mathrm{n}=10)$ in the clam. The variability in enzyme activity among animals was quite high. The laminarinase activity found in both animals is of interest in that this substrate is the primary carbohydrate storage molecule of marine brown algae. Freshwater molluscs may have carbohydrases that can digest a variety of glucose polymers.

\section{ALASKA MARICULTURE INITIATIVE - WHY NOT ALASKA? SIX ECONOMIC CASE STUDIES OF SUCCESS- FUL MARICULTURE INDUSTRIES AND THEIR POTEN- TIAL RELATIONSHIP TO A STATEWIDE STRATEGIC PLAN TO DEVELOP THE ALASKAN INDUSTRY Julie Decker' ${ }^{1}$, Katherine Wellman ${ }^{2}$}

${ }^{1}$ Alaska Fisheries Development Foundation, P.O. Box 2223, Wrangell, AK, 99929, USA

${ }^{2}$ Northern Economics, 1455 NW Leary Way, Suite 400, Seattle, WA, 98107, USA

The potential economic impact of a fully developed mariculture industry in Alaska is not well understood by industry or policy makers. It is also not entirely clear what is needed to move from Alaska's current micro industry (approximately $\$ 500,000$ in annual sales) to a fully developed industry. In general, the existing seafood industry (harvesters and processors) does not consider itself to be potential beneficiaries of mariculture development. Since the Aquatic Farm Act was passed in 1988, allowing for aquatic farming of shellfish and marine plants in Alaska, the stakeholders and agencies have not been acting in coordination to expedite the development of the industry, pointing to the necessity for a statewide strategic plan. The Alaska Fisheries Development Foundation (AFDF) is spearheading the Alaska Mariculture Initiative (Initiative), which will develop a clear and comprehensive statewide strategic plan. An important part of the Initiative is an economic analysis to inform the decisions to be made in the creation of the strategic plan. Phase I of the economic analysis will be six comparative case studies which outline examples of successful mariculture industries in different regions of the world with similar or relevant environmental and/or economic conditions to Alaska, including native species and potential stakeholders. The results of these case studies will be presented as well as their potential relationship to the Alaskan statewide strategic plan.

\section{ASSESSING THE PRESENCE AND IMPACT OF DENSOVI- RUS ON SEA STAR WASTING DISEASE IN ASTERIAS FORBESI}

Caitlin DelSesto $^{1}$, Jillon McGreal ${ }^{1}$, Marta Gomez-Chiarri ${ }^{1}$, Roxanne Smolowitz ${ }^{2}$, Gary Wessel ${ }^{3}$

${ }^{1}$ University of Rhode Island, Department of Fisheries, Animal and Veterinary Science, 120 Flagg Road, Kingston, RI, 02881, USA

${ }^{2}$ Roger Williams University, 1 Old Ferry Road, Bristol, RI, 02809, USA

${ }^{3}$ Brown University, MCB Department, 185 Meeting Street, Box GL 173, Providence, RI, 02912, USA

As keystone predators, sea stars serve to maintain biodiversity and distribution through trophic level interactions in intertidal ecosystems. Sea Star Wasting Disease (SSWD) has caused widespread mass mortality of Asterias forbesi in locations along the Northeast Coast of the US in recent years. A similar disease has 
been described in several sea star species from the West Coast of the US. Recently, a densovirus has been associated with wasting disease in West Coast sea stars and a few limited samples of $A$. forbesi. The goal of this research is to describe the pathogenesis of SSWD in A. forbesi and other echinoderms in the Northeast Coast and to determine if the densovirus isolated from West Coast sea stars is associated with the SSWD of $A$. forbesi on the eastern US coast. Histological examination of $A$. forbesi tissues affected with SSWD has shown cuticle loss, edema, and vacuolation of cells in the epidermis. We see no evidence of bacterial agents in tissues examined. Challenge experiments by cohabitation and immersion in infected water suggest that the cause of SSWD is viral in nature, since filtration $(0.22 \mu \mathrm{m})$ of water from tanks with SSWD does not diminish the transmission and progression of the disease. Death of challenged sea stars occurred 7-10 days after exposure to infected water or sea stars. The presence and levels of densovirus in samples of $A$. forbesi collected from wild populations and challenge experiments will be determined using polymerase chain reaction (PCR). Understanding the potential cause of this disease is a first step towards management and prevention of wide spread outbreaks.

\section{ASSESSING THE EFFECT OF SALINITY ON BARNACLE ADHESION AND BIOMINERALIZATION}

Gary H. Dickinson ${ }^{1}$, Conall G. McNicholl ${ }^{1}$, Beatriz Orihuela ${ }^{2}$, Daniel Rittschof ${ }^{2}$

${ }^{1}$ The College of New Jersey, Department of Biology, 2000 Pennington Road, Ewing, NJ, 08628, USA

${ }^{2}$ Duke University Marine Laboratory, 135 Duke Marine Lab Road, Beaufort, NC, 28516, USA

Barnacles are dominant members of marine biofouling communities throughout much of the world's oceans. The base of the barnacle attaches to surfaces with secreted proteinaceous adhesives that bond with surfaces and cure. Although the biochemical mechanisms involved in barnacle adhesion are starting to be understood, relatively little is known about how the environment affects barnacle adhesion and base plate mineralization. Here, the impact of variations in salinity on adhesion strength and biomineralization in the barnacle Amphibalanus amphitrite was assessed. Barnacle larvae were cultured from adults collected from the Beaufort Inlet, NC, where salinity is typically within the range of 30 - 36. Larval cultures were maintained at a salinity of approximately 35. Barnacles were settled on T2 silicone coated glass panels. Starting at 11 days post-settlement, juveniles were gradually acclimated to eight target levels of salinity, ranging from $10-$ 45 in steps of five. After six weeks growth at target salinities mortality was low on all panels and not significantly affected by salinity. Growth, measured as area of the barnacle base plate, was also not affected by salinity. We will report on ongoing assessments of adhesion strength, the composition and abundance of adhesive proteins, and micromechanical properties of the shell plates (microhardness, fracture toughness, and density). Initial results suggest that $A$. amphitrite is well-adapted to a broad range of environmental salinities.

MOLECULAR CHARACTERIZATION AND QUANTITATIVE EXPRESSION ANALYSIS OF MYOSTATIN GENE FROM THE BLOOD CLAM, TEGILLARCA GRANOSA

Yinghui Dong, Zhihua Lin

Zhejiang Key Laboratory of Aquatic Germplasm Resources, College of Biological and Environmental Sciences, Zhejiang Wanli University, 8 South Qianhu Road, Ningbo, Zhejiang, 315100, China.

Myostatin (MSTN), a member of the Transforming Growth Factor- $\beta$ (TGF- $\beta$ ) family, is a potent negative regulator of skeletal muscle development and growth in mammals and fish. Although several cDNA sequences of MSTN in mollusca, like Argopecten irradians and Chlamys farreri, have been characterized and their expression in adult tissues has been examined recently, its role in shellfish muscle development and growth remains unknown. Here, we reported the full-length cDNA of MSTN gene from Asian commercially important species blood clam (Tegillarca granosa) and quantitative expression profiles in adult tissues and embryos/ larvae. The complete cDNA of $T$. granosa MSTN (Tg-MSTN) gene was 3153bp (GenBank accession No. KP250872), containing a $1275 \mathrm{bp}$ ORF which encoded 425 amino acids. Blast analysis revealed that the deduced amino acid sequence is most similar to known MSTN, containing a conserved proteolytic cleavage site (RXXR) and conserved cysteine residues in the C-terminus. A quantitative analysis of adult (two-year-old clam) tissue expression profiles indicated that the Tg-MSTN gene is predominantly expressed in foot and adductor muscle, with limited expression in other six tissues, in keeping with results for mammalian MSTNs, suggesting a conservation of function in muscle growth regulation. The results of the embryonic expression profile revealed that Tg-MSTN transcript was undetectable in fertilized eggs, 2-4 cell and blastula, and barely detected from gastrulae. The expression level rose immediately in trochophore, and the significantly higher expression level of Tg-MSTN was observed in eyespot larvae and juvenile clams, which implied that it may play an important role in the regulation of muscle development.

DECORATING BEHAVIOR IN LOXORHYNCHUS CRISPATUS AND CONSEQUENCES OF POSSIBLE MUTUALISMS FROM LIVING ON A MOBILE ENVIRONMENT

\section{Catherine Drake, Jonathan Geller}

California State University, Moss Landing Marine Laboratories, 8272 Moss Landing Road, Moss Landing, CA, 95039, USA

With more than 800 species globally and more than 230 species locally in North American waters, the superfamily Majoidea contains a wide diversity of crabs. And yet, most species in this 
superfamily behave similarly by decorating themselves. They have hooked bristles on their appendages and carapaces, called setae, which allow the crabs to attach items from their environment to their bodies to camouflage themselves and avoid predation. Local to the eastern Pacific coast, the masking crab, Loxorhynchus crispatus, may behave similarly to other spider crabs in three distinct ways: either by selectively placing chemical deterrents on their carapaces, using their bodies for food storage, or by simply mimicking their environment. Despite variations in its local habitat, generally the same taxonomic groups are found on L. crispatus, such as bryozoans, tunicates, sponges, and various algae, throughout its habitat range (Wicksten 1978). This general trend might suggest that the crabs are preferentially choosing these taxa for decoration, yet this selectivity remains unexplored in previous studies. Additionally, it is not known whether the decorative organisms benefit from living on this mobile environment, potentially leading to mutualistic symbioses. As crabs decorate themselves, they could either facilitate or inhibit the wellbeing of the selected organisms. Thus, this study aims to answer the following hypothesis: (1) Is there evidence that the crabs are targeting their decorative organisms in a non-random way, and (2) Are there measurable benefits or costs for organisms inhabiting a crab carapace? Initial results from photo-quadrat analysis will be presented.

DOES RECRUITMENT DRIVE FLUCTUATIONS IN BURROWING SHRIMP POPULATIONS IN U.S. WEST COAST ESTUARIES AND AFFECT SHELLFISH AQUACULTURE? Brett Dumbauld $^{1}$, Lee McCoy ${ }^{1}$, Katelyn Bosley ${ }^{2}$, John Chapman ${ }^{2}$

${ }^{1}$ Hatfield Marine Science Center, USDA-ARS, Newport, OR, 97365, USA

${ }^{2}$ Oregon State University, Department of Fisheries and Wildlife, Newport, OR, 97365, USA

Two species of burrowing shrimp, Neotrypaea californiensis and Upogebia pugettensis, are important members of intertidal mudflat communities in Pacific Northwest coastal estuaries but cause significant problems for shellfish culture. Populations of these shrimp were monitored in Willapa Bay, Washington for two decades and in several other estuaries since 2005. Densities of both shrimp species were either increasing or stable through the mid1990s in Willapa Bay and then began to decline. Upogebia pugettensis are now almost absent in Willapa Bay and many other estuaries along the West Coast due in part to the introduced parasitic isopod, Orthione griffenis which compromises reproduction. Recent surveys of $N$. californiensis populations, however, suggest that they too were declining. Since both shrimp have pelagic larval stages that develop in the coastal ocean, we asked whether inter-annual fluctuations in larval survival and estuary recruitment influenced adult populations and shrimp populations on shellfish aquaculture beds. Relatively high recruitment for both shrimp was observed in Willapa Bay through the mid-1990s, but a period of about 10 years lapsed with very low recruitment. This loosely correlates with the decline in adult densities in that estuary and we also found a relationship between recruitment and the population of older shrimp. A substantial ghost shrimp recruitment event to Yaquina Bay, Oregon in 2010 and repeated though slightly lower recruitment to Willapa Bay from 2011-2013 resulted in population increases in these estuaries, and the survival and growth of these shrimp are currently being tracked.

\section{THE MOLLUSCAN BROODSTOCK PROGRAM - IMPROVING PACIFIC OYSTERS FOR WEST COAST FARMERS THROUGH SELECTIVE BREEDING}

\section{Evan Durland, Blaine Schoolfield, Chris Langdon}

Coastal Oregon Marine Experiment Station and Departments of Fisheries and Wildlife, Hatfield Marine Science Center, 2030 OSU Drive, Newport, OR, 97365, USA

The Molluscan Broodstock Program (MBP) was initiated in 1996 at Oregon State University (OSU) with the goal of improving Pacific oyster (Crassostrea gigas) production on the West Coast United States through genetic selection. MBP utilizes a familybased breeding design and was originally founded with wild broodstock collected from Washington State and British Columbia, Canada. In 2012, this program transitioned into a co-operative project (named iMBP) between OSU and numerous industry partners on the Pacific coast. Breeding design and hatchery production of cohorts of about 60 families are undertaken by OSU at the Hatfield Marine Science Center, Newport, Oregon, and families are planted out at industry-supported field sites for trait estimation. Large-scale transfer of germplasm to industry is accomplished each year by strategically crossing top-performing families and pooling them into four mutually unrelated "pods" that are produced in large quantities for use as broodstock by commercial hatcheries. In addition to West Coast C. gigas stock, iMBP has established pure pedigreed lines of Midori (C. gigas) and Kumamoto (C. sikamea) oysters founded with specimens collected from southern Japan (Ariake Sea) in 2004 and 2006, respectively. Data from $5^{\text {th }}$ generation cohorts show enhanced yields of iMBP pedigreed families in field traits and $3^{\text {rd }}$ generation data from Kumamoto and Midori oyster cohorts indicate promise for future selective breeding of these boutique stocks.

\section{BLACK ABALONE (HALIOTIS CRACHERODII) ABUN- DANCE AND HABITAT AVAILABILITY IN SOUTHERN CALIFORNIA}

Kari A. Eckdahl, Danielle C. Zacherl

California State University, Fullerton, Department of Biological Science, Box 6850, Fullerton, CA, 92834-6850, USA

The black abalone (Haliotis cracherodii) is an endangered species that was once abundant in the rocky intertidal zone of southern California until overfishing and Withering Disease drastically reduced populations on the mainland and the Channel 
Islands. The black abalone was listed as endangered in 2009. Its current geographic range is from Point Arena, California, USA to Bahia Tortugas, Mexico; however, since the mid-1990s, black abalone have been rare south of Point Conception on the California mainland coast. In recent years, populations on the Channel Islands experienced recruitment, but the current status of black abalone on the southern CA mainland remained unknown. Rocky intertidal surveys for black abalone were conducted from Point Conception to San Diego to determine if recruitment is occurring on the mainland and to measure population density. Habitat assessments were also conducted to document black abalone habitat availability. Black abalone are present but rare along the southern CA coast; the presence of smaller individuals indicates recruitment has occurred within the last few years. Densities are much lower than the published minimum density required for successful spawning to occur. Good black abalone habitat remains, but in some areas, sessile organisms occupy potential recruitment space.

\section{SPATIAL PATTERNS OF SPAT DENSITY IN RELATION TO DISTANCE FROM NATIVE OYSTER REEFS IN GREAT BAY ESTUARY, NEW HAMPSHIRE \\ Robert Eckert}

University of New Hampshire, 85 Adams Point Road, Durham, NH, 03824, USA

Oyster restoration aims to restore the ecological functions of native oyster reefs. Understanding how proximity to a native oyster reef affects recruitment patterns will assist in restoration site selection. In this study, spatial patterns of oyster recruitment were studied at three native oyster reefs in Great Bay Estuary. Mesh cages used for sampling oyster spat were placed on native reefs and at 200, 400, 600, 800 and 1000 meters upstream and downstream of native reefs. There was a significant decrease in spat densities as proximity from a native reef increased, while recruitment was not significantly different upstream or downstream from a native oyster reef. Results suggest that restoration efforts should consider extending the natural boundary of native oyster reefs to provide the greatest potential for natural recruitment and thus long-term reef development.

GONAD YIELDS AND SENSORY ATTRIBUTES OF GREEN SEA URCHINS FOLLOWING ENHANCEMENT FEEDING WITH EITHER DRIED KELP, FRESH KELP, OR FORMULATED DRY FEED

\section{Stephen Eddy ${ }^{1}$, Mary Ellen Camire ${ }^{2}$, Ung Wei Kenn}

${ }^{1}$ University of Maine, Center for Cooperative Aquaculture Research, 33 Salmon Farm Road, Franklin, ME, 04634, USA

${ }^{2}$ University of Maine, Dept. of Food Science and Nutrition, 5735 Hitchner Hall, Room 105, Orono, ME, 04469, USA
Green sea urchins Strongylocentrotus droebachiensis were fed ad libitum for 120 days with the objective of increasing their gonad yields while maintaining or enhancing culinary attributes. Mature hatchery reared (farmed) and field collected (wild) urchins were fed a mixed algal diet (kelp blend) consisting of Saccharina latissima and Laminaria digitata, or with the Nofima diet from Norway. Five treatments were compared using two holding/rearing methods (horizontal cages floating single layer in shallow V-troughs, or vertical cages stacked in a deep tank). Feed treatments were: farmed urchins fed fresh kelp blend, farmed urchins fed dried kelp blend, farmed urchins fed Nofima, wild urchins fed dried kelp blend, and wild urchins fed Nofima. Urchins were sampled at intervals to track and compare gonad yields. Farmed or wild urchins fed the Nofima diet had significantly greater increases in gonad yield than those fed kelp. After 120 days, urchin gonad sensory attributes from three of the feeding/rearing combinations were evaluated by a taste panel, along with wild, freshly caught sea urchins. Thirty-eight consumers recruited via flyers and word of mouth scored color, appearance, flavor, and firmness attributes. Overall, the panelists preferred wild, freshly caught sea urchins over any of the treatments. For color and appearance, the urchins fed Nofima scored as well as wild freshly caught urchins. In terms of flavor, firmness and overall quality, wild urchins fed dried kelp were liked as much as wild, freshly-caught urchins. Farmed urchins fed the dried kelp scored lower than wild, freshly caught urchins for all attributes.

\section{MOST PUGET SOUND OLYMPIA OYSTERS (OSTREA LURIDA) BELONG TO A NORTHERN MITOCHONDRIAL HAPLOTYPE GROUP}

Douglas J. Eernisse ${ }^{1}$, Ryan N. Crim ${ }^{2}$, Erik M. Pilgrim ${ }^{3}$

${ }^{1}$ California State University Fullerton, Department of Biological Science, Fullerton, CA, 92834, USA

${ }^{2}$ Puget Sound Restoration Fund, 382 Wyatt Way NE, Bainbridge Island, WA, 98110, USA

${ }^{3}$ US Environmental Protection Agency, Ecological Exposure Research Division, National Exposure Research Laboratory, Cincinnati, OH, 45268, USA

An unexpected mitochondrial haplotype divergence in Ostrea lurida was first documented in 2009 between Vancouver Island, British Columbia (either side at about $49.0^{\circ} \mathrm{N}$ ) versus a more widespread southern haplotype group found between Baja California, Mexico (about $28.0^{\circ} \mathrm{N}$ ) and the type locality for $O$. lurida at Willapa Bay on the outer coast of Washington (about $46.6^{\circ} \mathrm{N}$ ). Two of us (DJE and EMP) with other collaborators have recently sequenced an additional mitochondrial gene region, COI, for some of the oysters sequenced for COIII and 16S in the 2009 study and again found evidence of this genetic break. For COI, this corresponds to a greater than four percent average pairwise sequence divergence compared with only about a one percent COI average pairwise divergence 
between $O$. lurida and its more southern sister species, O. conchaphila. Here we add COI and $16 \mathrm{~S}$ sequences from a still small number of oysters from three localities within Puget Sound (47.2 to $48.3^{\circ} \mathrm{N}$ ). All but one of our sequenced Puget Sound oysters had the Vancouver Island haplotype. The one exceptional southern haplotype was an oyster from Fidalgo Bay, Washington, but it is possible that this could be a descendant of farmed oysters transported from Willapa Bay or further south. The geographic pattern is surprising because we are unaware of other marine species with a phylogeographic break or species-level transition at similar latitudes in western North America. Further characterization of $O$. lurida mitochondrial variation in the Salish Sea is relevant to ongoing restoration efforts for this species.

INDUCED HSP70 EXPRESSION IN THE CARPET SHELL CLAM, TAPES DECUSSATUS, ENHANCES RESISTANCE AND IMMUNITY AGAINST MICROCOCCUS LUTEUS Eman El-Wazzan', Bahaa Abdella ${ }^{1}$, Doaa Ghareeb ${ }^{2}$, Nermeen A. El-Sersy $^{3}$

${ }^{1}$ National Institute of Oceanography and Fisheries, Marine Invertebrates Lab, Aquaculture Division, Qaiyet-Bay, El-Anfoushi, Alexandria, 21556, Egypt

${ }^{2}$ Alexandria University, Department of Biochemistry, Moharam Bek, Alexandria, 21511, Egypt

${ }^{3}$ National Institute of Oceanography and Fisheries, Microbiology Lab., Marine Environmental Division, Qaiyet-Bay, ElAnfoushi, Alexandria, 21556, Egypt

Exposure to bacterial pathogens causes mass mortalities and tremendous losses in cultured bivalves. Therefore, there is need for hardier clam strains. Heat shock proteins 70 (Hsp70) play important role in enhancing innate immune response to several environmental stressors in bivalves. The present study is a trial to enhance disease resistance in clams using trained immunity strategy by inducing Hsp70 expression to protect clams against re-infection with Micrococcus luteus. Hsp70 was quantified in Tapes decussatus gill tissue using ELISA throughout two 17-days infection periods separated by 7-days depuration period for recovery. Infection and re-infection were applied by bathing clams (Shell length $=21.3-$ $25.73)$ in seawater with two bacterial concentrations $\left(5.0 \times 10^{4}\right.$ and $7.5 \times 10^{4} \mathrm{CFU} / \mathrm{ml}$ ) and compared to pathogen-free controls. Infection with $M$. luteus significantly induced Hsp70 expression as compared to controls with up-regulation in infected clams proportional to bacterial concentration. The attained higher Hsp70 values in infected clams during the first infection persisted after transfer of clams to clean seawater for recovery and decreased slightly but still exceeded non-infected controls. Re-infection with M. luteus re-increased Hsp70 expression but with higher levels reflecting more ability of clams to produce Hsp70 when preinfection was applied. The immune response was faster following the first infection. However, the highest hsp70 values and highest survival in all treatments were attained after re-infection. These results support the involvement of Hsp70 in immune response to bacterial infection in $T$. decussatus. Possible use of trained immunity strategies is suggested to protect $T$. decussatus against pathogens re-infection.

ASSESSING LONG-TERM TEMPORAL AND SPATIAL VARIATION IN SETTLEMENT OF OSTREA LURIDA IN NEWPORT BAY, CALIFORNIA

Michael Espinoza, Jennica Castillo, Thomas Parker, John Berriman, Lilly Sam, Ernesto Casillas, Sarah Pfrmmer, Ricky Atallah, Danielle Zacherl

California State University Fullerton, Department of Biological Science, Fullerton, CA, 92831, USA

Efforts to restore the Olympia oyster, Ostrea lurida, along the U.S. West Coast have motivated interest in building baseline data sets on oyster demographics. Knowledge about temporal and spatial variation in larval settlement provides baseline information about which locations receive the most larval input and have the potential to support large populations, facilitating selection of future restoration sites. Larval settlement was monitored by placing replicate ceramic tiles $(n=4)$ at six locations within Upper and Lower Newport Bay, Newport, California from 2007 to 2014. Tiles were replaced at 2-week intervals during the oyster reproduction season (May-Oct), and 1-month intervals during the remainder of the year. $O$. lurida settlers were counted using a dissecting microscope and data were converted to average settlers $/ \mathrm{m}^{2} /$ day for seasonal comparisons and cumulative numbers of settlers $/ \mathrm{m}^{2}$ per site for comparisons across years. Two of the six sites consistently received the greatest numbers of settlers. For these two sites, there was no consistent pattern in the timing of pulses across years, with sites in some years receiving two pulses, but in other years receiving only one short pulse or only one extended pulse. Pulses occurred anywhere from late-May to early-August. There were no exceptional years that received higher settlement across all sites, indicating that settlement dynamics may not be fully controlled by bay-wide phenomena, but rather may be at least partly controlled by localized factors. Future research will focus on exploring factors, such as local adult density, salinity, and/or temperature that may explain variation in settlement among sites.

\section{THE ROLE OF Cv1MMP IN DIAPEDESIS AND WOUND HEALING IN THE EASTERN OYSTER}

Elizabeth Falwell $^{1}$, Marta Gomez-Chiarri ${ }^{2}$, Andrew S. Mount ${ }^{1}$

${ }^{1}$ Clemson University, Okeanos Research Laboratory, Department of Biological Sciences, Clemson, SC, 29634, USA

${ }^{2}$ University of Rhode Island, Department of Fisheries, Animal and Veterinary Science, 120 Flagg Road, Kingston, RI, 02881, USA

In adult oysters, wound healing and shell repair are mediated by hemocytes, which migrate to the wound front 
via diapedesis. These cells are known to deliver intracellularlyderived calcium carbonate crystals and subsequently assemble shell at the wound site. Although the mechanisms governing cellular diapedesis in bivalve molluscs are poorly understood, it was found that hemocytes migrate through a matrix of quenched DQ collagen and release significant fluorescence as a consequence of proteolytic activity, presumably from Cv1MMP, a zinc-dependent matrix metalloproteinase. This is significant, as MMPs classically degrade type I collagen during tissue remodeling to the wound site. This research further bolsters our collaborative efforts to explore shell repair and encapsulation with the application of expression studies of two important genes, $C v 1 \mathrm{MMP}$ and a phosphoprotein associated with the foliated shell layer, Folian, which both localize to the shell forming outer mantle epithelium.

SUSPENDED SEDIMENT RISKS AND SEDIMENT METALS ASSOCIATED WITH GEODUCK AQUACULTURE Jeffrey Fisher ${ }^{1}$, Marlene Meaders ${ }^{2}$, Scott Luchessa ${ }^{3}$

${ }^{1}$ Fisherport LLC, 9735 Steamboat Island Rd. NW, Olympia, WA, 98502, USA

${ }^{2}$ Confluence Environmental Company, 146 N Canal St., Suite 111, Seattle, WA, 98103, USA

${ }^{3}$ Ecological Solutions, Inc., 4013 32nd Ave W, Seattle, WA, 98199, USA

Investigations were conducted in 2007, 2008 and 2011 at two intertidal geoduck Panopea generosa aquaculture sites in Puget Sound to examine: (1) the concentration of sediments suspended during harvest, and the risk characteristics that the suspended sediments may pose to juvenile salmonids if exposed to the harvest plume, and (2) whether the use of polyvinyl chloride pipe for the initial two-years of growth results in localized sediment contamination from the leaching of metals and/or plastics from the PVC. The Severity of Effect score of the suspended sediment, based on Newcombe and Jensen's 1996 model, and a presumed 4-hour exposure period, was typically below five and no more than six. These model output values suggest ephemeral changes in fish behavior, or short-term physiological stress such as coughing could manifest if juvenile salmonids were confined within the harvest plume without avoidance opportunity. No statistically significant differences were detected in sediment metals from the reference and culture plots with a two factor Model II analysis of variance, with or without the consideration of the potential interaction of beach elevation, with the nominal exceptions of beryllium and manganese. The mean concentrations of metals in sediments from both the reference and culture plots were also consistently below those measured from background monitoring stations across the Puget Sound, with the exception of nickel, for which the mean Puget Sound concentration was essentially equivalent with the samples from the culture plot.
DEVELOPMENT OF A HIGH THROUGHPUT MICROPLATE METHOD FOR THE DETERMINATION OF LARVAL BIVALVE RESPIRATION RATES IN OCEAN ACIDIFICATION STUDIES

\section{Brittany Flittner, Lisa Milke, Renee Mercaldo-Allen}

NOAA, National Marine Fisheries Service, Milford Laboratory, 212 Rogers Avenue, Milford, CT, 06460, USA

Ocean acidification limits the availability of carbonate ions which can reduce calcification, shell growth, and survival rate of calcifying organisms such as bivalves. While numerous studies have shown this impact, research remains limited concerning the impact of ocean acidification on larval shellfish respiration rates. This project aims to develop a simple, high throughput assay to determine larval respiration rates and to apply this method to further assess the impact of ocean acidification on bivalve health. Oxygen content was measured in 96 well microplates using the MitoXpress ${ }^{\circledR}$ Xtra probe. This probe binds with extracellular oxygen, creating a fluorescence signal which varies in response to the oxygen concentration. Relative fluorescence units were measured at intervals over the duration of the assay with a Molecular Devices SpectraMax ${ }^{\circledR}$ M2 Microplate Reader, and used to calculate oxygen consumption rate. During the development of this method, larvae of two different shellfish, Crassostrea virginica (eastern oyster) and Argopecten irradians (bay scallop) were tested. To date, seven trials have been conducted; parameters such as assay duration, fluorescence reading interval, animal number, animal enumeration and delivery technique were altered for method optimization. Although this assay is still in the developmental phase, differences in respiration rates have been observed over time and by varying the number of animals present within the sample. Ultimately, this assay will allow researchers to easily collect respiration rate data in conjunction with ocean acidification and other larval bivalve studies.

SNAIL MEETS CRAB: THE EFFECTS OF CHEMICAL CUES OF HEMIGRAPSUS SANGUINEOUS, THE ASIAN SHORE CRAB, ON THE PHENOTYPIC PLASTICITY OF THE ATLANTIC SLIPPERSNAIL CREPIDULA FORNICATA Yadira Flores ${ }^{1}$, Renata D'Agrella ${ }^{1}$, Rebecca Grella ${ }^{1}$, Dianna Padilla $^{2}$

${ }^{1}$ Brentwood High School, Brentwood, NY, USA

${ }^{2}$ Department of Ecology and Evolution, Stony Brook, NY, USA

To determine the potential impact of an invader, understanding the response of native species is crucial. In this study, the effect of Hemigrapsus sanguineus, the Asian shore crab, on Crepidula fornicata the Atlantic slippersnail, a gastropod native to eastern North America was assessed. Ten total chambers were constructed for an exposure assay lasting 50 days. Five chambers with $C$. fornicata were compared to five chambers with $C$. fornicata 
exposed to chemical cues from H.sanguineus. Initial measurements of shell length ( $\mathrm{mm})$, shell area ( $\mathrm{mm})$, and total wet mass $(\mathrm{g})$, were used with final measurements to determine growth. Final shell mass of each test snail were also measured. No statistically significant differences were found for snail growth in shell length, shell area, or wet mass, and final shell mass between snails exposed to chemical cues from the predator and the control treatment. There was a trend in growth in total mass with snails in the predator treatment growing less than those in the control, and final shell mass with those in the predator treatment having heavier shells. This study suggests that $C$. fornicata may have an induced response to Hemigrapsus sanguineus in terms of decreased body mass and increased shell mass in the presence of this predator; however, the lack of statistically significant effects could be due to the fact that $H$. sanguineous is a fairly new introduced species on Long Island shores.

\section{A POPULATION ASSESSMENT OF HORSESHOE CRABS (LIMULUS POLYPHEMUS) IN SOUTH CAROLINA, USA, USING AN INTEGRATED APPROACH}

Amy Fowler, Tanya Darden, John Robinson, Peter Kingsley-Smith

Marine Resources Research Institute, South Carolina Department of Natural Resources, 217 Fort Johnson Road, Charleston, SC, 29422, USA

The Atlantic horseshoe crab, Limulus polyphemus, is an important species both ecologically, as a food source for migrating shorebirds, and economically, as a harvested natural resource. Previously, L. polyphemus were harvested for fertilizer, and today is still used as bait in whelk and eel fisheries in some states. In South Carolina (SC), L. polyphemus is harvested only for the biomedical industry, in which live crabs are bled to produce Limulus amoebocyte lysate which is used to test for the presence of bacterial endotoxins. Estimates of post-bleeding mortality range widely, but an intermediate value of $15 \%$ is used for management purposes. Potential sublethal effects of bleeding and increasing harvests in portions of the species range have raised concerns over the longterm sustainability of horseshoe crab populations. To assess the status of horseshoe crabs in SC, in 2014 the SC Department of Natural Resources began an integrated monitoring program, including tagging studies, egg density surveys, and population genetic analyses. During the April to May 2014 spawning aggregations, a total of 1557 crabs were tagged in collaboration with the U.S. Fish and Wildlife Service. Initial egg density surveys showed no significant difference in egg or larvae densities between harvested and unharvested beaches. Population genetic data suggest a relatively large horseshoe crab population in the study area, with moderate to high levels of genetic diversity, no evidence for inbreeding, and effective population sizes of at least $\sim 2000$ individuals. Our data provide an important baseline for future monitoring and species management.
DEVELOPMENT OF DIAGNOSTIC PROTOCOLS FOR HEALTH ASSESSMENT OF LONG-SPINED SEA URCHINS, DIADEMA ANTILLARUM, IN FLORIDA

Ruth Francis-Floyd $^{1,2}$, Roy Yanong ${ }^{2,3}$, Jan Landsberg', Shirley Baker $^{2}$, Yasu Kiryu ${ }^{4}$, Tom Waltzek ${ }^{5}$, Deborah Pouder ${ }^{2,3}$, Mark Flint $^{2,6}$, Nicole Stacy ${ }^{1}$, Roxanna Smolowitz ${ }^{7}$, Greg Beck ${ }^{8}$, William Sharp $^{4,9}$

${ }^{1}$ University of Florida, College of Veterinary Medicine, Department of Large Animal Clinical Sciences, 2015 SW $16^{\text {th }}$ Ave, P.O. Box 100136, Gainesville, FL, 32610, USA

${ }^{2}$ University of Florida, Program in Fisheries and Aquatic Sciences, School of Forest Resources and Conservation, 7922 NW 71 Street, Gainesville, FL, 32653, USA

${ }^{3}$ Tropical Aquaculture Laboratory, $140824^{\text {th }}$ Street SE, Ruskin, FL, 33570, USA

${ }^{4}$ Fish and Wildlife Research Institute, Florida Fish and Wildlife Conservation Commission, 100 Eight Avenue SE, St. Petersburg, FL, 33701, USA

${ }^{5}$ University of Florida, Department of Infectious Diseases and Pathology, College of Veterinary Medicine, Bldg \#1379, Mowry Road, Gainesville, FL, 32610, USA

${ }^{6}$ Florida Aquarium, Center for Conservation, 701 Channelside Drive, Tampa, FL, 33602, USA

${ }^{7}$ Roger Williams University, Aquatic Diagnostic Laboratory, Department of Arts and Sciences, MNS 246, One Old Ferry Road, Bristol, RI, 02809, USA

${ }^{8}$ University of Massachusetts, Department of Biology, Wheatley Hall, 03, 0004, Boston, MA, 02125, USA

${ }^{9}$ South Florida Regional Laboratory, 2796 Overseas Highway, Suite 119, Marathon, FL, 33050, USA

The long-spined sea urchin, Diadema antillarum, is a keystone species in Atlantic coral reef ecosystems and is considered a species of "Greatest Conservation Need" by the Florida Fish and Wildlife Conservation Commission. Populations of $D$. antillarum declined by more than $90 \%$ in the 1980 s. Observations at the time were highly suggestive of an infectious etiology. The State of Florida is considering the use of $D$. antillarum for coral reef restoration efforts in selected areas of the Florida Keys and will include health assessment criteria as part of the permitting process. Consequently, investigators will work to identify potential pathogens, as well as describe "normal" fauna, in presumed healthy D. antillarum collected from Florida waters in 2015. Prior to the initiation of field collections, diagnostic techniques will be evaluated so that screening protocols can be standardized for routine examination of the species. The resulting "healthy D. antillarum" profile will include physical criteria, as well as descriptions of common commensals. To develop the "healthy Diadema" profile, diagnostic criteria will consider external characteristics such as body weight, test width and height, condition and distribution of spines, tube feet, and pedicillaria, uniformity of color and condition of gills. In addition, methods for internal 
examination and tissue collection will be standardized for cytology, parasitology, histology, immunological and coelomic fluid assessment. Microbial analysis using both culture and molecular tools will be conducted on selected samples. Diagnostic protocols and screening criteria determined to be appropriate for examination of wild $D$. antillarum collected from Florida waters will be presented.

\section{MUSSELLING MY WAY IN CALIFORNIA \\ Bernard Friedman}

Santa Barbara Mariculture Company, 4365 Cuna Dr., Santa Barbara, CA, 93110, USA

The only offshore shellfish farm in California has been operating off the coast of Santa Barbara for the last 12 years. Riding the wave of the local food movement, this farm is successfully providing local seafood to the community while undergoing intense scrutiny from permitting agencies. Parsing reality from fiction, and contemplating future demand for seafood, this farm is plotting a course into the unknown. Finding consensus and identity on the high seas is proving to be the challenge.

OLYMPIA (OSTREA LURIDA) AND JAPANESE (CRASSOSTREA GIGAS) OYSTER RECRUITMENT ONTO A CONSTRUCTED OYSTER BED IN ALAMITOS BAY, CA Cristina Fuentes $^{1}$, Alejandra Garcia ${ }^{1}$, Christine Whitcraft ${ }^{2}$, Danielle Zacherl $^{1}$

${ }^{1}$ California State University Fullerton, Fullerton, CA, 92834, USA

${ }^{2}$ California State University Long Beach, 1250 Bellflower Blvd (Mailstop 9502), Long Beach, CA, 90840, USA

Oyster restoration projects seek to increase oyster density via augmentation of mudflat with hard substrata to increase recruitment. The effects of a constructed oyster bed on the settlement and recruitment rates, and adult densities of native Ostrea lurida and non-native Crassostrea gigas were examined at Jack Dunster Marine Reserve in Alamitos Bay, CA. Dead C. gigas shell was used to construct a $2 \times 30 \mathrm{~m}$ bed. Throughout the next two years, shell loss via point-contact sampling was periodically monitored, settlement via deployment of replicate $(n=4)$ ceramic tiles, and recruitment and adult oyster density via excavation of replicate $(\mathrm{n}=7) 25 \mathrm{~cm}$ X $25 \mathrm{~cm}$ plots randomly placed within the bed and at an un-augmented control bed. After heavy shell loss of $\sim 72 \%$ after one year, the bed was augmented on the seaward side with more shell. There were higher densities of $O$. lurida recruits and adults on the constructed bed relative to the control, with densities on the initial bed $5 \mathrm{X}$, and on the new section of bed $62 \mathrm{X}$, those of reference populations throughout Alamitos Bay. Recruitment densities of $C$. gigas were $3 \mathrm{X}$ greater than reference populations. Adding more shell at the seaward side achieved a higher shell \% cover and increased $O$. lurida densities.
DISEASE TRANSMISSION AND ASSOCIATED MORTALITIES OF PACIFIC OYSTER (CRASSOSTREA GIGAS): DOES SALINITY MATTER?

\section{Marine Fuhrmann, Bruno Petton, Fabrice Pernet}

UMR 6539, LEMAR Ifremer/CNRS/UBO/IRD, Technopole de Brest-Iroise, Plouzané, France

Since 2008, mass mortalities of 1-year-old oysters, Crassostrea gigas, associated with ostreid herpes virus OsHV-1 $\mu$ Var, have occurred along all coasts of France and later in several other countries. The effect of four salinities, namely 10, 15, 25, $35 \mathrm{ppt}$, were tested on disease transmission and related mortalities in acclimated and non-acclimated oysters. Four-monthold naïve oysters were infected with water coming from tanks where field-infected animals were maintained. The results showed that the odds of mortality were much lower at $10 \mathrm{ppt}$ than that observed in other salinities for acclimated oysters. However for non-acclimated animals, odds of mortality at 10 ppt was much higher than that observed at other salinities, likely reflecting the effects of stressful environmental condition combined with infection. Levels of OsHV-1 DNA were lower in oysters maintained at $10 \mathrm{ppt}$ compared to that of animals held at 15-35 ppt. Therefore, it seems that low salinity could protect acclimated oysters from mortalities, as previously reported for the oyster Crassostrea virginica and its parasites. It was also observed that oysters acclimated at 10-15 ppt were smaller than those held at 25-35 ppt. The combined effects of salinity and infection on oyster physiology are now being investigated.

TRANSCRIPTOMIC ANALYSIS OF THE THERMAL STRESS RESPONSE IN CHRONIC AND ACUTE CONDITIONS IN PANOPEA GLOBOSA JUVENILES

Galindo-Sánchez C. E. ${ }^{1}$, I. Leyva, $\mathbf{F}^{2}$. Lafarga De La Cruz ${ }^{2}$, A. Lago-Leston $^{1}$, F. Díaz ${ }^{1}$, A.D. Re ${ }^{1}$, C. Gallardo-Escárate ${ }^{3}$

${ }^{1}$ Departamento de Acuicultura, Centro de Investigación Científica y de Educación Superior de Ensenada (CICESE), Carretera Ensenada-Tijuana \#3918, Ensenada, Baja California, México.

${ }^{2}$ CICIMAR-IPN. Av. Instituto Politécnico Nacional s/n, C.P. 23096, La Paz, B.C.S. Mexico

${ }^{3}$ Laboratory of Biotechnology and Aquatic Genomics, Interdisciplinary Center for Aquaculture Research (INCAR), University of Concepción, P.O. Box 160-C, Concepción, Chile

Within the genus Panopea, P. globosa inhabits either temperate or warmer waters. It distributes in the middle and northern region of the Gulf of California, and in the Pacific coast of Baja California Sur. From the four known populations, the upper Gulf of California population is the most exposed to high temperature variations, from $16^{\circ} \mathrm{C}$ to $32^{\circ} \mathrm{C}$. The species has a positive energy balance between 20 and $23^{\circ} \mathrm{C}$; moreover, the lethal temperature in adults can be of $32.5^{\circ} \mathrm{C}$. P. globosa is a species of high commercial value and the interest from cultivate is increasing; however, the 
information about the intraspecific adaptative mechanisms to survive both in temperate and warm temperatures is still unknown. In this work, we used Next Generation Sequencing techniques to develop the first assessment of the transciptomic response under two thermal stress conditions, chronic and acute.

INTERNAL ANATOMY AND BIOCHEMICAL CONTENT OF THE CORTEZ GEODUCK, PANOPEA GLOBOSA, DURING LARVAL DEVELOPMENT

Zaul Garcia-Esquivel ${ }^{1}$, Alejandra Ferreira-Arrieta ${ }^{1}$, Fabiola G. Arcos-Ortega ${ }^{2}$, Carmen Rodriguez-Jaramillo ${ }^{2}$, Ivone Giffard ${ }^{3}$

${ }^{1}$ Universidad Autonoma de Baja California, Instituto de Investigaciones Oceanologicas

${ }^{2}$ Centro de Investigaciones Biologicas del Noroeste, S.C., Mar Bermejo 195, Col. Playa Palo de Sta. Rita, La Paz BCS, 23090

${ }^{3}$ Facultad de Ciencias Marinas, Km 107 carretera TijuanaEnsenada, Ensenada, BC, Mexico

The internal morphology and biochemical patterns of the geoduck, Panopea globosa, were evaluated to identify the main functional organs, the energy storage sites, and the amount of energy reserves in oocytes (O), early straight-hinged (D), early umbone (eU), intermediate (iU), late (IU) and pediveliger larvae (Pe). Organisms were cultured in triplicate $500-\mathrm{L}$ conical tanks. Shell length was evaluated under the microscope. Histological mounts of larvae were stained with polychromic dye, while histochemical staining of separate samples was carried out with Sudan black (triglicerides, TG) or alcian blue - periodic acid Schiff (carbohydrtaes, CHO). The relative amount of biochemical components was digitally evaluated. Spectrophotometric quantitation of proteins, lipids and carbohydrates were also carried out in ca. 5 to $35 \mathrm{mg}$ dry weight samples. $P$. globosa larvae exhibited a linear shell growth pattern $\left(21 \mu \mathrm{m} \mathrm{d}^{-1}\right)$. Early "D" larvae showed a rudimetary digestive system lacking the digestive gland. The crystalline style, intestine and digestive gland appeared in the eU stage. Early formation of gills, foot, byssal gland and adductor muscles was also observed in this stage in the $1 \mathrm{U}$ stage. TG and $\mathrm{CHO}$ were mainly accumulated as droplets in the digestive gland, and their size increased with increasing larval age. Proteins, TG and $\mathrm{CHO}$ evaluated espectrophotometric and histochemically followed the same temporal pattern. $\mathrm{CHO}$ levels were consistently similar or higher than TG throughout the whole larval period of P. globosa, thus suggesting that the former plays a critical role as energy source of this species during early development and metamorphosis.

\section{PLASTIC PARTICLE UPTAKE BY OYSTERS, CRASSOSTREA VIRGINICA \\ Tamara Gaspar, Amy Ringwood}

University of North Carolina at Charlotte, Department of Biological Sciences, Charlotte, NC, 28223, USA
The global annual usage of plastics has increased dramatically with the annual demand reaching 288 million tons in 2012. Polystyrene is the fourth most common plastic material produced with many versatile applications. Consequently, there has been a coinciding increase in polystyrene wastes, much of which makes its way into waterways and oceanic habitats. While plastic debris has been shown to adversely affect many marine species, little has been studied regarding the effects of small-scale plastic particles on marine invertebrates. The primary purposes of this research are to compare the accumulation and toxicity of polystyrene micron and nano sized beads in oyster (Crassostrea virginica) hepatopancreas and gill cells. It was hypothesized that nano-sized polystyrene beads will be taken up more readily by hepatopancreas cells, and cause greater toxicity than micron sized polystyrene beads. Isolated hepatopancreas cells were used for four- hour in vitro cellular exposure studies and whole animals were used for 48-hour in vivo studies using two sizes of fluorescently labeled polystyrene beads $-50 \mathrm{~nm}$ and $3 \mu \mathrm{m}$. Numbers of fluorescing cells were measured using fluorescent microscopy. A lysosomal destabilization assay was used to evaluate toxicity. While there was no significant toxicity in either particle type over these short-term exposures, there were differences in cellular accumulation with nano particles being taken up more readily than micro. This work will provide important insights regarding the bioreactivity of plastic nanoparticles. Future experiments will involve marine pollutants to evaluate the "Trojan Horse" effect, the potential role that plastic particles might play in facilitating pollutant uptake.

THE CONNECTICUT SHELLFISH INITIATIVE: BUILDING ON THE PAST TO CREATE A VISION FOR THE FUTURE Tessa Getchis ${ }^{1}$, Nancy Balcom ${ }^{1}$, Anoushka Concepcion ${ }^{1}$, Sylvain De Guise $^{1}$, Julie Rose ${ }^{2}$

${ }^{1}$ Connecticut Sea Grant, University of Connecticut, Groton, CT, 06340, USA

${ }^{2}$ NOAA National Marine Fisheries Service Milford Laboratory, Milford, CT, 06460, USA

Shellfish are an important ecological, economic and recreational resource to Connecticut citizens. While there is considerable opportunity and growth in the various shellfish sectors, significant challenges exist and risk is pervasive. Lack of formal communication avenues and potential conflicts among industry, regulators, municipal officials and other shellfish stakeholder groups have limited much-needed collaboration to deal with emerging environmental and economic threats. In response to these challenges, Connecticut Sea Grant (CTSG) in collaboration with NOAA National Marine Fisheries Service Milford Laboratory convened meetings with shellfish interest groups and citizens across the State and proposed the development of a vision plan for the future of Connecticut shellfisheries and natural shellfish resources. Modeled after the NOAA National Shellfish Initiative, the Connecticut 
Shellfish Initiative is a stakeholder-driven effort to map out a vision for the future of Connecticut shellfish resources. The plan, now in development, will document the importance of the various shellfish sectors, identify and characterize issues of importance to Connecticut shellfish stakeholders and citizens and will establish specific and time bound goals, objectives and actions to be taken. To learn more visit: http://shellfish.uconn.edu.

\section{A NEW RESOURCE TO AID IN THE IDENTIFICATION AND MANAGEMENT OF AQUACULTURE PRODUCTION HAZARDS}

Tessa Getchis ${ }^{1}$, Deborah A. Bouchard ${ }^{2}$, Joseph Buttner ${ }^{3}$, John Ewart $^{4}$, Ann Faulds, George E. Flimlin ${ }^{6}$, Doris Hicks ${ }^{7}$, Craig Hollingsworth $^{8}$, Andrew Lazur ${ }^{9}$, Dale Leavitt ${ }^{10}$, Dennis McIntosh ${ }^{11}$, Dana L. Morse ${ }^{12}$, Tom Rippen ${ }^{13}$, Gregg Rivara ${ }^{14}$, Roxanna Smolowitz ${ }^{10}$, Dan Terlizzi $^{15}$, Don Webster ${ }^{16}$, Michael Chambers ${ }^{17}$, Diane C. Murphy $^{18}$, Robert Pomeroy ${ }^{1}$, Josh Reitsma ${ }^{18}$; Michael A. Rice ${ }^{19}$ and Nataliya Plesha ${ }^{1}$.

${ }^{1}$ Connecticut Sea Grant, University of Connecticut, 1080 Shennecossett Road, Groton, CT, 06340, USA

${ }^{2}$ University of Maine, 5735 Hitchner Hall, Orono, ME, 04469, USA

${ }^{3}$ Salem State College, Department of Biology, 352 Lafayette Street, Salem, MA, 01970, USA

${ }^{4}$ Delaware Sea Grant, University of Delaware, UDE 204K Cannon Marine, Lewes, DE, 19958, USA

${ }^{5}$ Pennsylvania Sea Grant, Pennsylvania State University, 1350 Edgmont Avenue, Chester, PA, 19013, USA

${ }^{6}$ Rutgers Cooperative Extension, 1623 Whitesville Road, Toms River, NJ, 08755, USA

${ }^{7}$ Delaware Sea Grant, University of Delaware, 700 Pilottown Road, Lewes, DE, 19958, USA

${ }^{8}$ University of Massachusetts, Agricultural Engineering Building, Amherst, MA, 01003, USA

${ }^{9}$ Maryland Sea Grant Extension Program, P.O. Box 775, Cambridge, MD, 21613, USA

${ }^{10}$ Roger Williams University, 1 Old Ferry Road, Bristol, RI, 02809, USA

${ }^{11}$ Delaware State University, 1200 N Dupont Highway, Dover, DE, 19901, USA

${ }^{12}$ Maine Sea Grant/University of Maine Cooperative Extension, Darling Marine Center, 193 Clark's Cove Road, Walpole, ME, 04573, USA

${ }^{13}$ University of Maryland Eastern Shore, Sea Grant Extension Program, Princess Anne, MD, 21853, USA

${ }^{14}$ Cornell Cooperative Extension, 3690 Cedar Beach Road, Southold, NY, 11971, USA

${ }^{15}$ Center of Marine Biotechnology, Columbus Center, Suite 236, 701 E Pratt Street, Baltimore, MD, 21202, USA
${ }^{16}$ University of Maryland, WREC, P.O. Box 169, Queenstown, MD, 21658, USA

${ }^{17}$ University of New Hampshire Sea Grant/UNH Coop. Extension, 219 Nesmith Hall, 131 Main Street, Durham, NH, 03824, USA

${ }^{18}$ Cape Cod Cooperative Extension \& Woods Hole Sea Grant Program, Box 367, Barnstable, MA, 02630, USA

${ }^{19}$ University of Rhode Island Cooperative Extension, Woodward Hall, Room 19, Kingston, RI, 02881, USA

Each year, the aquaculture industry experiences significant economic losses as a result of pathogens that cause disease, pests that render product unmarketable, operational mishaps, adverse weather events, and closures of harvest areas due to the presence of organisms with the potential to cause human illness. Collectively, we refer to these as aquaculture production hazards, which present considerable risk to operations. Massive loss of farmed product and human illness caused from ingestion of unknowingly contaminated product both adversely impact profitability, trade, and public perception. The ability of professionals to assist farmers is often limited by a lack of farm-level monitoring, record keeping, and farmer knowledge of hazards and hazard management strategies. Frequently, the causes of mortality events remain unknown or are identified when it is too late to prevent, control, correct or mitigate. Often, key pieces of information are missing from requests to identify and correct the hazard, limiting the response from extension and aquatic animal health professionals. To respond to this problem, a group of extension professionals from universities and industry associations across the northeastern U.S., together with researchers, aquatic animal health professionals, and industry members developed a publication, the Northeast Aquaculture Management Guide that identifies strategies to address aquaculture production hazards. The manual includes science-based information about major production hazards facing farmers, including: predators, diseases, parasites, organisms that have the potential to cause aquatic animal illness and human illness (e.g. toxic algae), biofouling, spread of invasive species, and other operational and environmental hazards. The manual also includes guidelines for environmental monitoring, evaluation and sampling of stocks, record-keeping procedures, and state-by-state contact information for whom to call when a problem occurs. The manual incorporates best management practices and biosecurity measures developed through research and outreach efforts. Improved knowledge of hazards associated with aquaculture production is the first step towards developing or improving risk management strategies. Use of appropriate farm monitoring protocols and record keeping will help aquatic animal health professionals respond better and more efficiently to illness or mortality events. If the causes of such events are identified quickly and definitively, future losses 
may be minimized or prevented, leading to increased production and profitability. The potential for realized economic benefits is significant; operators who plan proactively to minimize production hazards may have a competitive advantage in the marketplace.

EFFORT AND STRATEGY REPRODUCTIVE OF GEODUCK, PANOPEA GLOBOSA (DALL, 1898)

Sergio Scarry González-Peláez ${ }^{1}$, Carmen Rodríguez-Jaramillo ${ }^{1}$, J. Jesús Bautista-Romero ${ }^{1,}{ }^{2}$, Enrique Morales-Bojórquez ${ }^{1}$, Ma. Teresa Sicard-González ${ }^{1}$, Salvador Emilio Lluch-Cota ${ }^{3}$, Eduardo Romero-Vivas ${ }^{1}$, Daniel Bernado Lluch-Cota ${ }^{1}$

${ }^{1}$ Centro de Investigaciones Biológicas del Noroeste, SC, Instituto Politécnico Nacional 195, Col. Playa Palo de Santa Rita. CP 23096, La Paz, B.C.S., México

${ }^{2}$ Posgrado en Ciencias Marinas y Costeras, Departamento de Biología Marina de la Universidad, Autónoma de Baja California Sur, Carretera al Sur km 5.5, CP 23080, La Paz, B.C.S., México

${ }^{3}$ Dirección Adjunta de Centros de Investigación, Consejo Nacional de Ciencia y Tecnología, Av. Insurgentes Sur 1582, Col. Crédito Constructor, Del. Benito Juárez CP 03940, D.F., México

During November 2006 to October 2007, monthly samples of Panopea globosa were obtained from Bahía Magdalena on the western coast of Baja California Peninsula, Mexico. The samples ranged from 93 to $206 \mathrm{~mm}$ of shell length (SL) and 332 to $2,824 \mathrm{~g}$ in total weight (TW), with means of $158.43 \mathrm{~mm}$ and $1,528.73 \mathrm{~g}$ respectively. Gonad, digestive gland and adipogranular conjunctive tissues were analyzed by histological and histochemical methods. It was found that 89 males and 69 females, and 229 individuals undifferentiated. The sex ratio (male: female) was 0.55:0.45. The reproductive activity was observed from November to May, with synchronicity in both sexes. In November, females showed previtellogenesis in low frequency, reaching a maximum in December. The vitellogenesis started in December, increasing in January, and dropping in February. Postvitellogenesis began in February and March. Spawned and post-spawn individuals were observed from March to April. Finally, undifferentiated individuals were present from May to October. The oocyte diameter ranged from 7.5 to $83.5 \mu \mathrm{m}$, and showed monthly increments in the diameter according to the maturity stage. Changes of lipids coverage area observed in tissues suggested that $P$. globosa display a conservative strategy in the use of reserve energy tissue. The gametogenesis started when the monthly temperature decreases, and the reproductive event occurs three month previous to the maximum productivity measured in the region.
GROWTH MODELLING FOR EARLY STAGES OF GEODUCK, PANOPEA GLOBOSA, UNDER EXPERIMENTAL CONDITIONS

Sergio Scarry González-Peláez ${ }^{1,2}$, Enrique Morales-Bojórquez ${ }^{1}$, Viridiana Y. Zepeda-Benitez ${ }^{1}$, Alberto Espino-Calderín ${ }^{2}$, Guadalupe Muñoz-Urruela ${ }^{3}$

${ }^{1}$ Centro de Investigaciones Biológicas del Noroeste, SC, Instituto Politécnico Nacional 195, Col. Playa Palo de Santa Rita. CP, 23096, La Paz, B.C.S., México

${ }^{2}$ Sociedad Cooperativa Piripichi, Ocaso \# 181 e/ Aquiles Serdan y Atardeceres, Col. Puesta del Sol. CP 23060, La Paz, B.C.S., México

${ }^{3}$ Departamento de Biología Marina de la Universidad Autónoma de Baja California Sur, Carretera al Sur km 5.5, CP 23080, La Paz, B.C.S., México.

Growth was estimated for early growth stages of the geoduck Panopea globosa under experimental conditions. The fertilization in vitro was induced, and a sample size was of 887 individuals were sampled and analyzed. For larvae stage the samples were randomly selected during 21 days, and from the 34 day a systematic sample design was used for 72 individuals, the experiment was concluded at time 68 days. During this time the shell length (SL) was measured weekly. During the experiment the individuals showed an age interval from 1 to 68 days, and range of SL from $84 \mu \mathrm{m}$ to $5098 \mu \mathrm{m}$. Four individual growth functions that showed non-asymptotic patterns (two cases of the Schnute general model, persistence and Gompertz model) were fitted to shell length-at-age data. Using Akaike's information criterion and multi-model inference, we selected the best model to describe the growth pattern. It was found that the Schnute general model (two-parameters) was the best growth function describing total SL data for early stages of P. globosa, showing a power pattern.

LARVAL DEVELOPMENT OF THE SUBTROPICAL GEODUCK, PANOPEA GLOBOSA (BIVALVIA: HIATELLIDAE) Sergio Scarry González-Peláez ${ }^{1,4}$, Liliana Carvalho-Saucedo ${ }^{2}$, Alberto Espino-Calderín ${ }^{1}$, Carlos Rangel-Dávalos ${ }^{3}$, Daniel Bernardo Lluch-Cota ${ }^{4}$

${ }^{1}$ Sociedad Cooperativa Piripichi, Ocaso \# 181 e/ Aquiles Serdán y Atardeceres, Col. Puesta del Sol, CP 23060, La Paz, B.C.S., México

${ }^{2}$ Centro Regional de Investigación Pesquera, Carretera Pichilingue Km1, S/N Col. Esterito, CP 23020, La Paz, B.C.S. México

${ }^{3}$ Departamento de Biología Marina de la Universidad Autónoma de Baja California Sur, Carretera al Sur km 5.5, CP 23080, La Paz, B.C.S., México

${ }^{4}$ Centro de Investigaciones Biológicas del Noroeste, SC, Instituto Politécnico Nacional 195, Col. Playa Palo de Santa Rita, CP 23096, La Paz, B.C.S., México 
The embryonic and larval development stages of the geoduck Panopea globosa maintained under controlled conditions (19 $\mathrm{C}^{\circ}, 35 \%$, pH 8.4) were described using microphotographs and measurements of shell length (SL) and height (SH). Gametes were obtained from ripe broodstock and eggs fertilized with a dilute sperm solution. The fertilization was detected within 1020 minutes, then the completion of meiosis I with the first polar body extrusion was observed 15-20 minutes later. After fertilization, trochophore larvae $(94.80 \pm 0.74 \mu \mathrm{m}$ in SL and $82.92 \pm 4.69 \mu \mathrm{m} \mathrm{SH})$ were formed in 17.5 hours, veliger larvae $(146.36 \pm 17.54 \mu \mathrm{m}$ in SL and $121.78 \pm 15.96 \mu \mathrm{m} \mathrm{SH})$ were observed in 43 hours, umbo growth was apparent in 7 days, and the pediveliger larvae $(355.36+20.99 \mu \mathrm{m}$ in SL and 313.64 $+21.24 \mu \mathrm{m}$ in $\mathrm{SH}$ ) were formed in 21 days. Age and average size of SL for each stage during metamorphosis are compared to other species of Panopea. The relationship of SH and SL showed a linear pattern $(\mathrm{SH}=0.875+\mathrm{SL} *-2.20)$. The growth of $\mathrm{SH}$ and SL relationship showed a linear relationship with the time $(\mathrm{T}=$ days $)$ from the fertilization to pediveliger stage (SL $=81.40+\mathrm{T} * 12.04$ and $\mathrm{SH}=67.33+\mathrm{T} * 10.69$, respectively). For this species, the growth during larval development showed a proportional increase in the length of the shell with respect to its height, thus suggesting that highly uniform larvae sizes can be obtained from spawning runs in controlled conditions.

INVESTIGATING PHYSIOLOGICAL AND ECOLOGICAL EFFECTS OF REEF BALLS ON OYSTER (CRASSOSTREA VIRGINICA) POPULATIONS

Jacob Goodwin ${ }^{1}$, Elizabeth North ${ }^{1}$, Kennedy Paynter $^{2}$, Anne Handschy $^{2}$

${ }^{1}$ University of Maryland, Horn Point Laboratory, Center for Environmental Science, Cambridge, MD, USA

${ }^{2}$ University of Maryland, Department of Biology, College Park, MD, USA

Current oyster restoration techniques in Chesapeake Bay include planting juvenile oysters (spat) on shell and spat on reef balls. Reef balls provide valuable three dimensional habitats for finfish and other species but little is known about the effect they may have on oyster growth, abundance, or disease tolerance. To assess this, measurements were made on reef balls that had been planted in the Chesapeake Bay in 2004. During the same year spat on shell was planted on and around the reef balls. During fall of 2014, SCUBA divers were used to sample in three treatments: 1) on reef ball 2) near and around reef balls, and 3) control sites of spat on shell with no reef balls. Total mean oyster abundance was significantly highest on reef ball treatments $\left(92 \mathrm{~m}^{2}\right)$ compared to around near and around reef balls $\left(48 \mathrm{~m}^{2}\right)$ and the control treatment $\left(54 \mathrm{~m}^{2}\right)$. There was a wider size distribution with smaller $(<60 \mathrm{~mm})$ oysters on reef ball treatments compared to other treatments which could indicate higher recruitment. In addition to these results, disease prevalence of $P$. marinus will be presented for each treatment group.

USING A NOVEL AUTOMATED IDENTIFICATION TECHNIQUE TO ENHANCE UNDERSTANDING OF EASTERN OYSTER (CRASSOSTREA VIRGINICA) LARVAL BEHAVIOR AND MORTALITY

Jacob Goodwin, Elizabeth North

University of Maryland, Horn Point Laboratory, Center for Environmental Science, Cambridge, MD, USA

Collecting bivalve larvae at temporal and spatial scales suitable to understand behavior and mortality has been a challenge. Larval swimming behavior and mortality affects the distribution, abundance, and transport of bivalve larvae. Knowledge of bivalve larvae is limited due to their small size, the similarity between species, and lack of a low-cost, automated approach for identification. A novel image analysis technique for identifying oyster larvae (ShellBi) that utilizes species specific birefringence patterns shown under polarized light was applied. The ShellBi method is combined with an automated image acquisition system to rapidly enumerate and measure bivalve larvae in hundreds of field samples collected from a fixed station cruise and two additional mapping cruises in the Choptank River, a sub-estuary of Chesapeake Bay. ShellBi was used to identify eastern oyster larvae with high $(>90 \%)$ accuracy. Results indicate that over $85 \%$ of oyster larvae were found above the $5 \mathrm{mg} / \mathrm{L}$ oxycline. The majority (87\%) of smaller (64-200) $\mu \mathrm{m}$ larvae were found above the maximum salinity gradient. In addition, mortality estimates for field and hatchery oyster larvae will be presented.

\section{SEA LEVEL RISE AND SEAGRASS EXPANSION IN WILLAPA BAY, WA: HOW WILL CHANGES IN ZOSTERA MARINA DISTRIBUTION INFLUENCE AQUACULTURE? \\ Erin Graham, Brett Dumbauld, Lee McCoy}

USDA-ARS, 2030 SE Marine Science Drive, Newport, OR, 97365, USA

Sea level rise (SLR) poses a significant threat to coastal systems. Global mean sea level is predicted to rise $0.28 \mathrm{~m}$ to $0.98 \mathrm{~m}$ by 2100 , relative to 1986-2005 levels, and local relative SLR may be considerably larger. Rising sea level is causing many physical effects in coastal habitats, and one concern is how these changes will alter the density and distribution of seagrasses, which provide numerous ecosystem services. In the Pacific Northwest, seagrass beds often overlap with shellfish aquaculture beds, and the presence of eelgrass can restrict (legally and physically) the availability of land to be farmed. As SLR continues, shifts in seagrass density and distribution will present additional challenges 
for shellfish growers wishing to maintain and expand their operations, and for managers, who are tasked with preserving seagrass habitat. In this study, the current distribution of eelgrass, Zostera marina in Willapa Bay, WA was modeled across the tidal flat and within aquaculture beds. The coverage of $Z$. marina was then predicted for the years 2030, 2050 and 2100 using two sea level rise scenarios. The model predicts an increase in $Z$. marina coverage for all years, resulting in as much as $40 \%$ more eelgrass in aquaculture beds by 2100 . However, the model also reveals that changes in coverage are likely to be bed specific, as $Z$. marina will decrease in some aquaculture beds and increase in others. Potential "hotspots" of seagrass expansion in Willapa Bay were identified and implications for shellfish aquaculture and eelgrass as habitat discussed.

FEEDING PHYSIOLOGY OF THE NATIVE OLYMPIA OYSTER (OSTREA LURIDA) AND THE INTRODUCED PACIFIC OYSTER (CRASSOSTREA GIGAS): IMPLICATIONS FOR ECOSYSTEM SERVICES AND RESTORATION Matthew Gray, Chris Langdon

Oregon State University, Coastal Oregon Marine Experimental Station, Hatfield Marine Science Center, and Department of Fisheries and Wildlife, Newport, OR, 97365, USA

The native Olympia oyster, Ostrea lurida, was once abundant in coastal waters of the Pacific Northwest (PNW) but was decimated in the late $19^{\text {th }}$ and early $20^{\text {th }}$ centuries, largely due to overharvesting, habitat degradation and pollution. Since then, the nonnative Pacific oyster Crassostrea gigas has replaced $O$. lurida as the dominant oyster species in many PNW estuaries. The effects of these changes on ecosystem services provided by oyster clearance and deposition of suspended materials are not well understood. In this study, we describe results from laboratory and in situ experiments in which the feeding physiology of adult $O$. lurida was compared to that of $C$. gigas. Laboratory experiments determined the separate effects of temperature, salinity, and turbidity while in situ studies determined clearance and deposition rates under dry and wet seasons in Yaquina Bay, Oregon. From these studies we constructed models to predict the feeding behavior of each species in dynamic environments. It was found that in situ-based models were better predictors of oyster feeding behavior under natural conditions compared with laboratory-based models. Predictive models are useful in developing restoration programs that benefit from ecosystem services provided by oyster populations.

A NOVEL DUAL BEAD TECHNIQUE FOR EVALUATING THE FEEDING PHYSIOLOGY AND BEHAVIOR OF BIVALVE LARVAE

Matthew Gray', Sean Kramer ${ }^{2}$, Chris Langdon ${ }^{1}$

${ }^{1}$ Oregon State University, Coastal Oregon Marine Experimental Station, Hatfield Marine Science Center, and Department of Fisheries and Wildlife, Newport, OR, 97365, USA
${ }^{2}$ Norwich University, Department of Mathematics, College of Science \& Mathematics, Northfield, VT, 05663, USA

Historically, clearance rates of bivalve larvae have been indirectly determined by measuring rates of decrease in concentrations of suspended algal cells using electronic particle counters; however, this method does not take into account production of fecal and pseudofecal particles that may be of similar size to uneaten algal cells, resulting in under estimates of feeding rates. Using a series of exposures to differently colored fluorescent polystyrene microspheres, a novel technique to directly quantify ingestion rates and gut fullness, as well as to indirectly determine clearance rates and gut passage times of mussel larvae is described. Additionally, microsphere processing patterns observed using this technique provide insight into the digestive kinematics of the larval gut. In this study, the dual bead technique to determine the effects of developmental stage and temperature on the larval feeding and digestive physiology of the Mediterranean mussel Mytilus galloprovincialis is applied. In conclusion, this technique is a useful tool for evaluating the feeding and digestive processes of bivalve larvae and potentially other planktotrophic invertebrate larvae.

\section{UNDERSTANDING THE REPRODUCTIVE ENDOCRINOL- OGY OF THE RED DEEP SEA CRAB, CHACEON QUIN- QUEDENS: IDENTIFICATION OF REPRODUCTIVE REGULATORS AND VITELLOGENIN}

Shadaesha Green, J. Sook Chung

Institute of Marine and Environmental Technology, University of Maryland Center for Environmental Science, 701 E Pratt Street, Baltimore, MD, 21202, USA

The reproductive strategy of crustaceans is closely related to their life history and requires precise regulation of neuroendocrine and non-neuroendocrine related compounds. Our current knowledge that has been gleaned largely from the studies of warm water crustacean species suggests that hormones derived from the eyestalk ganglia mainly regulate various reproductive strategies in females. Specifically, members of $\mathrm{CHH}$ superfamily: crustacean hyperglycemic hormone $(\mathrm{CHH})$ and molt-inhibiting hormone (MIH) stimulate and/or inhibit vitellogenesis, the process of yolk protein synthesis and accumulation in oocytes. Little has been known about the reproductive endocrinology of deepsea coldwater crustacean species including the red deepsea crab, Chaceon quinquedens. The main objective of this study is to identify putative reproductive/molting regulators of the female red deepsea crab. First, the presence of $\mathrm{CHH}$ and $\mathrm{MIH}$ has been established in the X-organ cells and the sinus gland of eyestalk ganglia using PAGE-Westernblot analysis and immunohistochemistry. With a degenerate PCR and molecular cloning technique, a partial cDNA sequence for $\mathrm{CHH}(\mathrm{ChqCHH})$ containing two thirds of the open reading frame and a relatively short 
3' untranslated region was isolated. The putative amino acid sequence of $\mathrm{ChqCHH}$ and ChqMIH is related most closely to Carcinus maenas $\mathrm{CHH}$. Additionally, using the same cloning strategy, a partial vitellogenin cDNA sequence of $C$. quinquedens encompassing the lipoprotein $\mathrm{N}$-terminal domain (317 amino acids) was obtained and shares $\sim 75 \%$ sequence identity with that of the snow crab, Chionoecetes opilio. This study ultimately aims to unravel the reproductive strategy of the female red deep sea crab (C. quinquedens).

OF MARSH AND MUSSELS: PILOT SCALE LIVING SHORELINE IMPLEMENTATION ON MARTHA'S VINEYARD, MASSACHUSETTS

\section{Emma Green-Beach, Richard Karney}

Martha's Vineyard Shellfish Group Inc., P.O. Box 1552, Oak Bluffs, MA, 02557, USA

The island of Martha's Vineyard (Massachusetts) has limited salt marsh, but that which exists provides very important ecological benefits including storm protection, primary productivity, stormwater and nutrient mitigation, and habitat for numerous marine organisms. Because of serious water quality degradation associated with nitrogen overloads, the nitrogen mitigating capacities of Spartina grasses and super-filtering ribbed mussels, Geukensia demissa, methods to increase marsh acreage have special appeal. With funding from Massachusetts Coastal Zone Management, the Martha's Vineyard Shellfish Group (MVSG) has initiated a pilot scale project to demonstrate the effectiveness of using living shoreline technology to increase marsh area. Four small demonstration deployments are planned- two each in both low and high wave energy sites. The rational for this design is to be able to evaluate the application of the technology at different types of sites. To date, living shorelines have been installed in both low-energy sites, with the involvement of local high school students. Installations are adapted from the Delaware Bay Living Shoreline Initiative (DELSI) method, using coir logs, marsh grass, shellbags and ribbed mussels. In order to supply this project, as well as future remediation projects, with a dependable supply of ribbed mussels, spawning, larval and nursery culture methods for ribbed mussels are being investigating. Successes and challenges to date will be discussed, as well as plans for the 2015 season.

UNDERSTANDING ENVIRONMENTAL CONDITIONS THAT SUPPORT SUSTAINABLE OLYMPIA OYSTER POPULATIONS: INFORMING RESTORATION AND CONSERVATION

E.D. Grosholz ${ }^{1}$, J. Bible ${ }^{2}$, E. Ceballos ${ }^{3}$, A.L. Chang ${ }^{3}$, B.S. Cheng ${ }^{2}$, A. Deck $^{4}$, M. Ferner ${ }^{4}$, M. Latta ${ }^{5}$, K. Wasson ${ }^{6}$, C. Zabin ${ }^{1,3}$

${ }^{1}$ University of California Davis, Department of Environmental Science and Policy MORE?
${ }^{2}$ University of California Davis, Bodega Marine Laboratory, MORE?

${ }^{3}$ Smithsonian Environmental Research Center, Tiburon, CA, USA

${ }^{4}$ San Francisco Bay National Estuarine Research Reserve, Tiburon, CA, USA

${ }^{5}$ California State Coastal Conservancy, Oakland, CA, USA

${ }^{6}$ Elkhorn Slough National Estuarine Research Reserve, Watsonville, CA, USA

Olympia oysters have been at low abundance in western North America following more than a century of overexploitation and habitat degradation. Recent work has successfully developed new approaches for conservation and restoration of this species in California, Oregon and Washington. In support of these and future efforts, new data from field surveys and experimental studies that quantify the threats posed by current anthropogenic and climate-driven stressors has been produced. These data were used to examine the potential for Olympia oyster conservation and restoration at specific sites in Elkhorn Slough and San Francisco Bay. Oyster population metrics most strongly associated with populations of high priority for conservation and restoration were evaluated. The data showed that large adult population size and high density, high rate of juvenile recruitment, diversity of size classes, and high juvenile and adult survival rates were the most important indicators of sustainable oyster populations. The most important stressors for oysters in this region were determined to be low salinity, predation by oyster drills, high air temperatures when exposed, and low dissolved oxygen. Several other stressors were less important including competition with fouling species, sedimentation, contaminants, pathogens and disease, sea level rise and estuarine acidification. In conclusion, present, localized threats to oysters should be of equal, or of more concern, to managers than most climate change stressors. The guidelines developed in this study will help future efforts to conserve and restore Olympia oysters in a changing world, and will broadly inform estuarine ecosystem management.

\section{RESILIENCE OF THE OYSTER SEEN THROUGH ITS GENOME \\ Ximing Guo}

Rutgers University, Haskin Shellfish Research Laboratory, Institute of Marine and Coastal Sciences, 6959 Miller Avenue, Port Norris, NJ, 08349, USA

Life originated from the ocean, and studying genomes of marine organisms is critical to our understanding of the history of evolution and adaptation. Molluses are a group of ancient animals that emerged over 540 million years ago. They stand now as the most speciose and diverse group of marine animals. Oysters are representative bivalve molluscs that are widely distributed in world oceans. As successful colonizers of intertidal zones and estuaries, oysters have developed remarkable resilience against 
harsh environmental conditions. Oysters can tolerate wide fluctuations in temperature and salinity. They can survive months without water and thrive in microbe-rich environments as filter-feeders without adaptive immunity. The sequencing of the oyster genome provides an opportunity to study genomic bases for oyster's amazing resilience. Analyses show that key genes related to stress and immune responses are expanded. However, gene expansion comes with cost, and it is not clear why a large number of duplicated genes instead of a few powerful ones are needed for strong stress tolerance. In this study, I analyzed the expression patterns of some duplicated genes. Members of expanded gene families show diverse expression profiles under different conditions. For example, different heat shock proteins are specialized to function at different salinities and temperatures. It seems that duplicated genes have diversified to respond to different environmental conditions. The varying environments that oysters live in may have favored the retention and diversification of duplicated genes related to stress and immune responses, which may be central to oyster's amazing resilience against diverse environmental challenges.

\section{HOW MUCH IS ENOUGH? USING ECOSYSTEM SERV- ICES TO SET OBJECTIVES FOR OYSTER HABITAT RES- TORATION}

Boze Hancock ${ }^{1}$, Line zu Ermgassen ${ }^{2}$, Robert Brumbaugh ${ }^{3}$, Bryan DeAngelis ${ }^{1}$, Jennifer Greene ${ }^{4}$, Mark Spalding ${ }^{5}$, Elizabeth Scheuster $^{6}$

${ }^{1}$ The Nature Conservancy, URI Bay Campus, 215 South Ferry Rd., Narragansett, RI, 02882, USA

${ }^{2}$ Fitzwilliam College, Department of Zoology, University of Cambridge, Trinity Lane, Cambridge CB2 1TN, United Kingdom

${ }^{3}$ The Nature Conservancy, 127 Industrial Road, Suite D, Big Pine Key, FL, 33043, USA

${ }^{4}$ The Nature Conservancy, 56 Saint Joseph Street, Suite 1600, Mobile, AL, 36602, USA

${ }^{5}$ The Nature Conservancy, 2350 Route 47, Delmont, NJ, 08314, USA

For several years a group of researchers led by The Nature Conservancy have been quantifying the ecosystem service benefits delivered through the restoration of oyster habitat. Services include shoreline protection, denitrification, filtration and fish production. Estimates of these services have been published in the peer reviewed literature, the most recent being estimates of fish production from oyster habitat on the Atlantic and Gulf of Mexico coasts. This has been done to enable the use of these ecosystem services as a mechanism to set objectives for oyster restoration on a system-wide basis, allowing practitioners to promote realistic expectations for the scale of restoration required to achieve the desired level of services such as water filtration or the number or tonnage of a fish species to be delivered. A manager's guide that encapsulates the methods for estimating the area of restored oyster habitat required to achieve system-wide objectives, with worked examples, will be presented and an interactive web site being developed to allow online calculation of the area of oyster habitat restoration required to achieve the desired levels of ecosystem services will be described.

EFFECTS OF ARTIFICIAL SUBSTRATE TYPE AND REEF HEIGHT ON THE SURVIVAL OF OYSTERS IN THE CHOPTANK RIVER, MARYLAND, USA

Anne Handschy ${ }^{1}$, Matthew Spitznagel ${ }^{1}$, Kennedy Paynter ${ }^{1-3}$

${ }^{1}$ Department of Biology, University of Maryland, 1210 Biology-Psychology Bldg. 144, College Park, MD, 20742, USA

${ }^{2}$ University of Maryland Center for Environmental Science, Chesapeake Biological Laboratory, 1 Williams St., Solomons, MD, 20688, USA

${ }^{3}$ Marine Estuarine and Environmental Science, University of Maryland, 1213 HJ Patterson, College Park, MD, 20742, USA

In the fall of 2014, we surveyed seven artificial reefs in the Choptank River of the Maryland portion of Chesapeake Bay. These reefs were constructed by the Army Corps of Engineers Baltimore District, and were built to either $1 \mathrm{ft}$ tall or taller, consisting of granite with or without a shell veneer. All seven were seeded with spat on shell from the UMCES oyster hatchery in 2011. Several points on each reef were sampled using a quadrat, resulting in oyster size, mortality and density estimates. Additionally, the substrate was examined for natural spat set. Preliminary results suggest that substrate is more important than reef height, with better survival on reefs that included a layer of shell. The results of this study will be presented, which have implications for large-scale restoration costs and success.

WHAT HAS BEEN HAPPENING OVER THE YEARS? DELVING DEEPER INTO BIOTOXIN AND PHYTOPLANKTON MONITORING IN WASHINGTON STATE

\section{Adi Hanein, Jerry Borchert}

Office of Shellfish and Water Protection, Washington State Department of Health, 243 Israel Road SE, | Tumwater, WA, 98501, USA

The marine biotoxin monitoring program of the Washington State Department of Health (WDOH) has routinely collected and analyzed shellfish samples for biotoxins since 1957. The goal of the program is to ensure that recreationally and commercially harvested molluscan shellfish is safe for human consumption. The DOH analyzes over 3,000 biotoxin samples each year and the dataset currently has over 90,000 data points for three different biotoxins (Paralytic Shellfish Poison, Amnesic Shellfish Poison and Diarrhetic Shellfish Poison) from diverse shellfish species, monitoring sites, and collection dates. The monitoring program also collaborates with SoundToxins and Olympic Region Harmful Algal Bloom Partnership to track toxin-producing plankton species, such as Pseudonitzschia spp., Alexandrium catenella, and Dinophysis spp. These 
programs allow WDOH to track population dynamics and identify harmful algal blooms (HAB) earlier than when toxins begin appearing in the shellfish. This early warning provides WDOH with a proactive way to adapt to emerging threats, to better monitor shellfish and alert managers to HAB in the area, and ensure that shellfish are safe for human consumption. This presentation provides site-specific and regional trends observed over the years as well as an overview of current and future collaborations that focus on precautionary and modeling research.

\section{GENOMIC AND TRANSCRIPTOMIC EVIDENCE FOR FUNCTIONAL OYSTER DIFFERENTIATION WITHIN SINGLE ESTUARIES}

Matthew P. Hare

Cornell University, Department of Natural Resources, Ithaca, NY, 14850, USA

Rapid environmental change is motivating research to predict the capacity for population responses based on dispersal, plasticity and natural selection. Eastern oysters (Crassostrea virginica) have a bet-hedging life history whereby high genetic diversity and high fecundity support a recruitment sweepstakes with winners determined partly by how well phenotypes match post-settlement microhabitat. With strong post-settlement selection each generation, low salinity parents generally produce a distinct set of zygotic genotypes - with distinct phenotypic capacities - relative to zygotes produced by high salinity parents. Assuming these genotypes get thoroughly mixed within the estuary via larval dispersal, the whole process gets more or less repeated every generation without cumulative change of allele frequencies in the estuary population. The extent of this dynamic, and the evolutionary constraints that have evolved as a result, are important to determine because they influence the oyster's capacity to adapt (e.g. to new pathogens) and may point to improved restoration procedures. To measure the extent of post-settlement differential viability selection and relate it to phenotypic plasticity, the low- and high-salinity oyster samples from single estuaries with molecular sampling at the genomic and transcriptomic levels were compared. The data confirm high gene flow within estuaries, but also show adult oysters on reefs to be significantly differentiated in terms of allele frequency at a handful of sampled loci. Furthermore, reefs have distinct patterns of osmoregulatory plasticity based on common garden experiments. This talk will focus on the genetic data supporting these inferences. Restoration implications will be the focus of a separate presentation.

\section{REBUILDING A DIVERSE OYSTER POPULATION: SHOULD WE PLANT GENERALIST OR SPECIALIST OYSTERS? Matthew P. Hare}

Department of Natural Resources, Cornell University, Ithaca, NY, 14850, USA
Eastern oysters (Crassostrea virginica) have a bet-hedging life history whereby high genetic diversity and high fecundity support a recruitment sweepstakes with winners determined partly by a good match between phenotype and post-settlement microhabitat. Oyster restoration 'best practices' have mostly focused on genetic diversity with respect to minimizing hatchery bottlenecks and maximizing survivorship of outplanted oysters. Maximizing survivorship and oyster performance after planting are goals shared with aquaculture when seed oysters are distributed to growers with diverse environmental characteristics at their lease sites. Perhaps it is unsurprising that aquaculture oysters are used for restoration and often show fast growth and high survivorship; however, concern for closing the life cycle and restoring oysters with high fitness is unique to restoration - this is the only way to restore a self-sustaining population. Unfortunately, monitoring restoration impact across oyster generations is extremely difficult, so few data exist to evaluate current practices. Given this monitoring challenge, and the dearth of self-sustaining restored reefs, it is important to carefully consider additional factors besides seed performance and endeavor to increase mean fitness of restoration oysters. This talk will present results from genomic comparisons between wild and hatchery-produced oysters, relating their genetic differences to the functional genetic differentiation documented among wild oysters. The results suggest that oyster populations contain tolerant generalist oyster phenotypes and less plastic specialist phenotypes. For restoration, what are the conditions under which generalist vs. specialist broodstock generate a greater demographic and evolutionary contribution to the population?

HISTAMINE RECEPTORS IN GILL OF THE BIVALVE CRASSOSTREA VIRGINICA AND THE ACTIONS OF HISTAMINE AT GILL INTERFILAMENTAL JUNCTIONS

Ave Harris, Jarreau Harrison, Fabienne Mondelus, Edward Catapane, Margaret Carroll

Biology, Medgar Evers College, 1638 Bedford Avenue, Brooklyn, NY, 11225, USA

Histamine (HIS), a neurotransmitter in a number of invertebrates rarely has been reported in bivalves. Previous work showed in the bivalve Crassostrea virginica HIS is involved in sensory reception in regulation of gill lateral cell cilia beating, quantified HIS in ganglia and tissues and visualized HIS and HIS H2 receptors in tissues, including gill interfilamental junctions (IFJ). This work prompted the hypothesis that HIS $\mathrm{H} 2$ receptors can be confirmed by Western Blot and HIS has a physiological role at gill IFJ. For Western Blot, gill cell lysate was prepared by polytron disruption in NP-40 detergent buffer containing protease inhibitor and centrifuged to obtain supernatant with solubilized membrane proteins. Up to $30 \mu \mathrm{g}$ of protein was subjected to SDS-PAGE with $10 \%$ acrylamide gels 
and electroblotted onto nitrocellulose. $\mathrm{H} 2$ receptor immunoreactivity was revealed by incubation with $\mathrm{H} 21^{\circ}$ antibodies then incubation with HRP-conjugated $2^{\circ}$ antibodies. Gill H2 receptor protein was resolved by colormetric development using $\mathrm{CN} / \mathrm{DAB}$ substrate kit. To determine a role of HIS at IFJ we photographed response of IFJ to HIS and HIS antagonist famotidine. Western Blot showed a $70 \mathrm{kD}$ band corresponding to HIS $\mathrm{H} 2$ receptors. The physiology study showed HIS $\left(10^{-3}-10^{-5} \mathrm{M}\right)$ caused a dose-dependent contraction of IFJ that were blocked when famotidine $\left(10^{-3}-10^{-5} \mathrm{M}\right)$ was applied prior to HIS. The study confirms immunohistofluorescence findings of $\mathrm{H} 2$ receptors in gill of $C$. virginica and identifies a physiological role of HIS in gill.

ECOLOGICAL CONDITION AND VALUE OF OYSTER REEFS OF THE SOUTHWEST FLORIDA SHELF ECOSYSTEM Lesli Haynes ${ }^{1}$, Patricia Goodman ${ }^{1}$, Patricia Gorman², Barbara Welch $^{2}$, Aswani Volety ${ }^{3}$

${ }^{1}$ Vester Marine Field Station and Coastal Watershed Institute, Florida Gulf Coast University, 10501 FGCU Boulevard, Fort Myers, FL, 33965, USA

${ }^{2}$ South Florida Water Management District, 3301 Gun Club Road, West Palm Beach, FL, 33406, USA

${ }^{3}$ University of North Carolina Wilmington, 601 South College Road, Bear Hall 146, Wilmington, NC, 28403, USA

One component of the Comprehensive Everglades Restoration Plan (CERP) is an attempt to restore hydrology in south Florida estuaries. The eastern oyster Crassostrea virginica is a prolific and dominant feature of those estuaries and coastal areas in the Gulf of Mexico. Using the monitoring data from on-going studies, this study examined various metrics of oyster health, reproduction and survival to develop an index to create an overall state of oyster reefs in Southwest Florida estuaries. We have developed a communication tool (Stoplight Report Card system) based on CERP performance measures for oyster biological responses. The communication tool involves a suitability index score for each organism metric as well as a trend score (- decreasing trend, +/- no change in trend, and + increasing trend). Based on these two measures, a component score (e.g., living density) is calculated by averaging the suitability index score plus the trend score. The final eastern oyster index score is obtained by taking the geometric score of each oyster component and translating it into a stoplight color for success (green), caution (yellow), or failure (red). Based on existing data, oyster reefs in Southwest Florida estuaries are at "caution", but stable. Restoration of a more natural freshwater inflow, minimizing nutrient and contaminant input as well as decreased sedimentation will enable oyster reefs to expand and thrive.
EVIDENCE OF OSTREA LURIDA (CARPENTER 1864) POPULATION STRUCTURE IN PUGET SOUND, WASHINGTON, USA

Jake Heare ${ }^{1}$, Brady Blake ${ }^{2}$, Jonathan P. Davis ${ }^{3}$, Brent Vadopalas ${ }^{1}$, Steven B. Roberts ${ }^{1}$

${ }^{1}$ University of Washington, School of Aquatic and Fishery Sciences, Box 355020, Seattle, WA, 98195, USA

${ }^{2}$ Washington Department of Fish \& Wildlife, 375 Hudson Street, Port Townsend, WA, 98368, USA

${ }^{3}$ Puget Sound Restoration Fund, 382 Wyatt Way NE, Bainbridge Island, WA, 98110, USA

Where restoration efforts occur, such as with Ostrea lurida in Puget Sound, Washington, it is important to consider genetic population structure. Traits that hold adaptive advantage such as reproductive timing and stress resilience may differ at local scales. Using three established populations of O.lurida within Puget Sound, Washington, a reciprocal transplant experiment was performed and survival, growth, reproduction was monitored. Results showed that performance differed for each population at each of these three metrics. Ostrea lurida from a relatively harsh home site environment with low primary production and high dynamic habitats exhibited generally greater survival at all sites, whereas those from a relatively lush home site environment with high primary production and lower habitat dynamics exhibited generally greater reproductive activity at all sites. Populations from sites with shorter growing seasons exhibited greater growth in sites with longer growing periods, suggesting a countergradient adaptation may have occurred in these populations.

INDIVIDUAL GROWTH PROFILES AS ALTERNATIVE TO THE TERMINAL SIZE-AT-AGE METHOD IN PANOPEA GENEROSA STUDIES

José Angel Hidalgo-de-la-Toba ${ }^{1}$, Sergio Scarry González-Peláez ${ }^{1}$, Enrique Morales-Bojórquez ${ }^{1}$, J. Jesús Bautista-Romero ${ }^{1,2}$, Daniel Bernardo Lluch-Cota ${ }^{1}$

${ }^{1}$ Centro de Investigaciones Biológicas del Noroeste, SC, Instituto Politécnico Nacional 195, Col. Playa Palo de Santa Rita, CP 23096, La Paz, B.C.S., México

${ }^{2}$ Posgrado en Ciencias Marinas y Costeras, Departamento de Biología Marina de la Universidad Autónoma de Baja California Sur, Carretera al Sur km 5.5, CP 23080, La Paz, B.C.S., México

The Pacific geoduck, Panopea generosa, has been used as a study model on environmental reconstructions because of its extraordinary longevity and capacity to register synchronic signals of growth in shell. Recently, the amplitude in the growth increments has allowed the elucidation of its relationships with the environmental variability. In the Mexican northwest, the recent discovery of this clam and their fast fishery development has generated a considerable interest to understand the populations 
dynamic. The last study about the southernmost $P$. generosa population has shown signs of decreasing in key elements for their fitness (e.g. sizes, weights, ages and individual growth) as a response to the environmental stress by being located in its geographical distribution limit. The absence of young individuals has been a limiting factor that diminishes the geoduck's growth model accuracy, as consequence of sample bias. In this way, we propose an alternative to the traditional method based on the terminal size-at-age to improve the modeling of the individual growth. This method identify each inner annual growth lines in a cross section in the shell to be assigned with its respective external growth line to estimate the size reached at every age by the clam. A multimodel inference approach was applied over the individual growth profiles observed for each organism. Furthermore, the annual anomalies calculated from the growth increments allow identifying growth patterns related to environmental variables and climate indices for this marginal population.

\section{MICROBIAL CONSORTIA ASSOCIATED WITH SEDIMENT NITROGEN REMOVAL AT OYSTER AQUACULTURE SITES IN CHESAPEAKE BAY \\ Colleen Higgins, Bonnie Brown}

Virginia Commonwealth University, Dept. of Biology, $1000 \mathrm{~W}$

Cary Street, Richmond, VA, 23284, USA

Expanding nitrogen $(\mathrm{N})$ sinks within ecosystems is one management approach aimed at mitigating estuarine eutrophication. At two oyster aquaculture sites in Chesapeake Bay, we evaluated the impact of oyster aquaculture and biodeposition on sediment microbial community composition and coupled nitrification-denitification as compared to nearby reference sites without aquaculture. Bacterial abundance was measured using DAPI staining and Fluorescent in situ Hybridization (FISH) to compare the abundances of total cell count, eubacteria, and nitrifying bacteria (ammonium-oxidizing bacteria and nitriteoxidizing bacteria) across treatments, sites and seasons. qPCR of the nos $Z$ gene was used to determine if oyster biodeposition (a proxy for increased $\mathrm{N}$ delivery to sediments) had an impact on denitrifier composition or abundance, and T-RFLP analysis (NMDS) of eubacteria and the nos $Z$ (nitrous oxide reductase) gene were used to elucidate the impact of oysters on community composition. Site (namely sediment particle size) not oysters, corresponded to total cell count, eubacteria (50-78\%), and nitrifying bacteria (20-30\% of eubacteria). Counts of nos $Z$ genes in the sediments were variable at both sites, with few significant differences between oyster and reference. Although the numbers of bacteria types did not differ with treatment, oyster biodeposition did result in quantifiable changes in both the eubacteria and nos $Z$ communities ( $\mathrm{p}<0.001$ ); however, nos $Z$ T-RFLP did not correlate significantly with $\mathrm{N}_{2}$ production. Biodeposition significantly impacted denitrifying the bacteria community composition at both sites (within $5 \mathrm{~m}$ ). The sediment microbial consortia provided important insight into the dynamics of oyster biodeposit nutrient processing not reflected by direct measures of $\mathrm{N}_{2}$ production.

BEHAVIOURAL AND PHYSIOLOGICAL EFFECTS OF CONDITIONS ASSOCIATED WITH HANDLING AND TRANSPORT ON BERRIED VELVET SWIMMING CRABS (NECORA PUBER)

Laura Hinchliff $^{1,2}$, Jaimie Dick ${ }^{1}$, Julia Sigwart ${ }^{2}$, Lynn Gilmore ${ }^{3}$

${ }^{1}$ School of Biological Sciences, Queen's University of Belfast, 97 Lisburn Road, Belfast, Co. Antrim, N. Ireland

${ }^{2}$ Queen's University Marine Laboratory, 12-13 The Strand, Portaferry, Newtownards, N. Ireland

${ }^{3}$ Seafish, Origin Way, Europarc, Grimsby, N.E. Lincs, England

Velvet swimming crabs (Necora puber) often become entangled in fishing gear, and force is required to remove them from creels. Rough handling can result in injury which has more detrimental consequences for berried females than less vulnerable crabs. To observe behavioral response to capture processes, handling assessments were carried out whereby berried females were randomly subjected to one of four handling types; none, minimal, moderate or severe. Post-handling, crabs were placed on their backs and timed to see how long it took to correct themselves. A common fishery practice is to place crabs upright to alleviate stress, and thus limits catch mortality. Experimental data showed that handled crabs took significantly longer to right themselves when conspecifics were present; however, crabs handled mildly showed the same response as crabs that received no handling. The aggressive nature of $N$. puber means that maintaining an upright defensive position is essential for self-protection, but crabs are less inclined to do so when conspecifics are absent. Egg counts before and after experimental treatment showed that handling did not affect brood size. To examine the physiological response of berried crabs to stressors associated with capture and transport, assays for glucose, glycogen and lactate will be carried out as these are indicative of levels of crustacean hyperglycaemic hormone $(\mathrm{CHH})$, which has been used as a measurement of stress in a range of crustacean species. Factors which are particularly stressful to berried crabs can be identified and recommendations made to industry in order to mitigate their effect.

ACTIONS TO INCREASE, RESTORE, AND PROTECT SHELLFISH RESOURCES THROUGH THE WASHINGTON SHELLFISH INITIATIVE

Laura Hoberecht

NOAA Fisheries, 7600 Sand Point Way NE, Seattle, WA, 98115, USA

In December 2011, Washington became the first state to implement the NOAA National Shellfish Initiative with the release of the Washington State Shellfish Initiative (WSI). The WSI is an 
agreement among federal and state governments, tribes and the shellfish industry to restore and expand Washington's shellfish resources, to promote clean-water industries and create familywage jobs. The WSI includes three primary components with specific action items identified for each: (1) create a public/private partnership for shellfish aquaculture; (2) promote native shellfish restoration and recreational shellfish harvest; (3) ensure clean water to protect and enhance shellfish beds. To date, nearly all of the 38 action items identified in the original WSI have been completed. Highlights of completed actions include products developed by the Shellfish Interagency Permitting Team, construction of a native shellfish hatchery, multiple acres of restored Olympia oyster habitat and mitigation recommendations from the Ocean Acidification Blue Ribbon Panel. Based on the success of the original WSI efforts are underway to develop an updated WSI with a suite of new action items.

EFFECT OF AIR EXPOSURE STRESS ON HEMOCYTE PARAMETERS OF THE VARIOUSLY COLORED ABALONE, HALIOTIS DIVERSICOLOR (REEVE, 1846)

Hyun-Ki Hong, Young Ghan Cho, Hyun-Sil Kang, Kwang-Sik Choi

Jeju National University, School of Marine Biomedical Science (BK21 PLUS), 102 Jejudaehakno, Jeju 690-756, Republic of Korea

Abalone are often exposed to atmosphere during transportation, resulting in mortality or physiological depression. In this study, we artificially exposed Haliotis diversicolor to air to investigate cellular level of impact. Abalones were placed in a moisturized and no-humidified chamber at room temperature. Total hemocyte count, hemocyte DNA damage, and phagocytosis capacity were examined at $6,12,24$, and $30 \mathrm{~h}$ using flow cytometry. Mortality occurred six hours after the exposure in dry chamber, and at $12 \mathrm{~h}$ in the moisturized chamber. All the abalone in the dry chamber died after $24 \mathrm{~h}$ of air exposure, while $20 \%$ of the abalone survived at the end of experiment in the humidified chamber. After $6 \mathrm{~h}$ in the air, percentage of the DNA damaged hemocyte of the abalone in the dry chamber was two to three times higher compared to the abalones in the humidified chamber and the control. At the end of the experiment, the DNA damage level of the abalones in the moisturized chamber was twice higher than the control. Results indicated that more than $24 \mathrm{hr}$ of exposure to air leads significant mortality and the cellular impairment in $H$. diversicolor.

SHELLFISH FARMING IN THE PACIFIC NORTHWEST: PUBLIC AND STAKEHOLDER PERCEPTIONS

Bobbi Hudson ${ }^{1}$, Thom Allen², Danna Moore ${ }^{2}$

${ }^{1}$ Pacific Shellfish Institute, 509 12th Ave \#14, Olympia, WA, 98501, USA

${ }^{2}$ Washington State University, Social \& Economic Sciences Research Center, P.O. Box 644014, Pullman, WA, 99164, USA
More than 4,000 residents of ten coastal counties in Washington, Oregon and California were surveyed for community views of shellfish aquaculture. The survey explored two overarching questions: "Are these communities opposed to or supportive of continued or expanded shellfish aquaculture?" and "What are the implications for aquaculture planning and development?" The survey, conducted by Pacific Shellfish Institute and partners at Washington State University Social \& Economic Sciences Research Center, elicited an unusually high $34 \%$ response rate and answers questions responding to a wide range of issues. It revealed the general view that shellfish farms "neither enhance nor detract from the scenery of coastal areas" and their "greatest benefit" is "providing locally produced seafood." A second survey also solicited a $>30 \%$ response rate after distribution to a broad array of local planners, federal and state agency staff, representatives of natural resource industries, citizen groups and conservation non-government organizations. Highlighted survey responses are presented, with a focus on informing public outreach and education efforts related to shellfish aquaculture, and to provide recommendations for aquaculture planning and development. This work is funded through Washington Sea Grant, pursuant to NOAA award \#NA14OAR4170078.

\section{APICOMPLEXAN INFECTION CAUSING GRAY MEAT IN THE ATLANTIC SEA SCALLOP, PLACOPECTEN MAGEL- LANICUS \\ Susan Inglis ${ }^{1}$, Árni Kristmundsson ${ }^{2}$, Mark A. Freeman ${ }^{3}$, Kevin Stokesbury ${ }^{1}$ \\ ${ }^{1}$ University of Massachusetts-Dartmouth, SMAST, Fairhaven, MA, USA \\ ${ }^{2}$ University of Iceland, Institute for Experimental Pathology at Keldur, Reykjavik, Iceland \\ ${ }^{3}$ Institute of Ocean and Earth Sciences, University of Malaya, Kuala Lumpur, Malaysia}

Atlantic sea scallop meats are normally firm and creamy white. Scallops with small, darkened and stringy adductor muscle (gray meat) periodically occur along the eastern seaboard. Recently reports of these scallops have increased, particularly in the rotational management areas of Georges Bank after extended fishing closures. These gray meat scallops are associated with reduced harvestable biomass and mass mortality events. Age, nutrition and disease were tested as causative agents. Adult scallops of different size classes were collected from Georges Bank and analyzed for meat quality and the presence of pathogens by histopathological and molecular methods. Scallop size and reproductive stage was uncorrelated with gray meat condition $(\mathrm{p}<0.05)$ but meat weight (yield) was reduced. A progressive myodegeneration of the muscle occurred in scallops with gray meat. Proximate analysis revealed a dramatic reduction in protein content 
(ANOVA; $\mathrm{p}<0.05)$ in gray meat scallops. Amino acid profiles confirmed a metabolic response to the breakdown of muscle tissue. Infection by an apicomplexan parasite was observed in the muscle tissue of all gray meat scallops. As the parasitic infection increased, meat quality decreased. This apicomplexan has an identical rDNA sequence to a novel parasite observed in the Iceland scallop during a mass mortality event. Numerous life stages are present in infected scallops suggesting direct transmission of the parasite. Current research focuses on managing the propagation of this infection. Fishermen are currently being interviewed to map gray meat outbreaks and identifying the habitat characteristics of these locations. Laboratory studies are testing transmission and virulence of the parasite.

USING MICROSATELLITE MARKERS TO COMPARE RESTORATION BREEDING METHODS FOR THE OLYMPIA OYSTER (OSTREA LURIDA)

Katherine Jackson ${ }^{1}$, Brent Vadopalas ${ }^{1}$, Brian Allen ${ }^{2}$, Steven Roberts ${ }^{1}$

${ }^{1}$ School of Aquatic and Fishery Sciences, University of Washington, Seattle, WA, 98195, USA

${ }^{2}$ Puget Sound Restoration Fund, 382 Wyatt Way Northeast, Bainbridge Island, WA, 98110, USA

The Olympia oyster, Ostrea lurida, is native to Puget Sound and the west coast of the United States. Due to overharvesting and water quality decline, the once thriving local population has decreased dramatically. In recent years, there has been an effort to start reestablishing this culturally, ecologically, and economically important animal. While methods have been created to breed genetically diverse, restoration grade oyster seed, there have been no quantitative studies to evaluate the genetic diversity of seed populations. In this study, seven microsatellite loci were used to evaluate genetic differentiation between oysters destined for restoration projects and wild populations. Pairwise comparisons were also conducted with commercially produced Olympia oysters as an outgroup. Expected heterozygosity, relatedness, allele frequency, and allele counts were analyzed within and between these groups. The highest relatedness was seen in the restoration population. When using allelic differentiation to compare allele frequencies, the difference was found to be highly significant between the wild and restoration populations, but no significant difference was detected between the wild and commercially produced groups. The results suggest that the breeding method used to produce commercial populations may be an effective method for retention of wild genetic diversity in a hatchery setting, conditioned on periodic genetic monitoring to ensure genetically diverse and compatible restoration populations of Olympia oysters in the future. This experiment will be repeated in spring 2015 using two wild populations and their offspring.
THE MOLECULAR IDENTIFICATION OF ICHTHYOPHONUS HOFERI AND ICHTHYOPHONUS IRREGULARIS IN YELLOWTAIL FLOUNDER LIMANDA FERRUGINEA FROM GEORGES BANKS

Whitney Jaillet ${ }^{1}$, Carlton Huntsberger ${ }^{2}$, Roxanna Smolowitz ${ }^{1}$, Ronald Smolowitz ${ }^{2}$

${ }^{1}$ Roger Williams University, 1 Old Ferry Road, Bristol, RI, 02809, USA

${ }^{2}$ Coonamessett Farm Foundation, 277 Hatchville Road East Falmouth, MA, 02536, USA

Ichthyophonus sp. is the cause of lethal and debilitating systemic infections in over 100 species of teleost fish. Recently Ichthyophonus sp. organisms were noted to cause moderate to severe disease and probable mortality in yellowtail flounder Limanda ferruginea populations sampled as part of a gear research project to develop a scallop dredge capable of eliminating yellowtail bycatch. Currently, yellowtail flounder populations, unlike most other regulated fish species along the Northeast coast of the United States, are not recovering from overfishing, and continue to be a choke species for the sea scallop industry. In 2000, Ichthyophonus irregularis was noted as the cause of Ichthyophonus infections in animals examined from Georges Bank, however it is unknown whether Ichthyophonus hoferi, or Ichthyophonus irregularis is the cause of disease noted in yellowtail flounder in the current study. Molecular work is underway to identify which species is present in yellowtail flounder sampled from Georges Banks in 2013 and 2014. An increased knowledge of the prevalence and distribution of I. hoferi and $I$. irregularis could lead to an improved understanding of the pathogenesis of the disease. It will help us to further understand where and how the disease causing parasites are acquired by the flounder as well as understand potential species differences in the ability of the parasites to cause disease and potentially limit the rebuilding of yellowtail populations.

\section{ASSESSING THE ACCURACY AND APPLICABILITY OF POOLING OYSTER TISSUES TO REDUCE THE COST OF PERKINSUS MARINUS DIAGNOSTICS}

Whitney Jaillet, Kathryn Markey, Roxanna Smolowitz

Roger Williams University, 1 Old Ferry Road, Bristol, RI, 02809, USA

Perkinsus marinus, the causative agent of Dermo Disease, is responsible for significant morbidity and mortality in populations of Crassostrea virginica along the Atlantic coast of the United States. In order to quickly and accurately determine prevalence and intensity of Dermo infections, the Aquatic Diagnostic Laboratory (ADL) has developed a quantitative PCR (qPCR) with a plasmid standard curve to detect and quantify levels of $P$. marinus within a population of oysters. In order to mitigate the cost of disease testing, aquaculturists often request that animals be tested in composites by pooling multiple animals together for an overall 
decrease in the number of molecular reactions required for each health check. While this strategy may be applicable to farmers who simply require a positive or negative result to transport animals from one location to another, the impact of composites on the accuracy and depth of information collected has not been assessed. This study compared prevalence and intensity results from animals tested individually, in groups of two animals per reaction, and five animals per reaction in order to determine whether the use of composites altered final results when compared to individual testing. This study allowed the laboratory to determine the accuracy and applicability of composite data in relation to the overall health of the oysters tested.

EXPLOITATION OF NUTRIENTS FROM SALMON AQUACULTURE: WHAT IS THE POTENTIAL FOR IMTA IN NORWAY?

H.M. Jansen ${ }^{1}$, A. Handå ${ }^{2}$, P. Cranford ${ }^{4}$, R. Bannister ${ }^{1}$, M. Bergvik $^{3}$, O.J. Broch ${ }^{2}$, S. Forbord ${ }^{2}$, V. Husa ${ }^{1}$, Y. Olsen ${ }^{3}$, K.I. Reitan $^{2}$, J. Skjermo², Ø. Strand ${ }^{1}$

${ }^{1}$ Institute of Marine Research, N-5817 Bergen, Norway

${ }^{2}$ SINTEF Fisheries and Aquaculture, N-7465 Trondheim, Norway

${ }^{3}$ Norwegian University of Science and Technology (NTNU), N-7491 Trondheim, Norway

${ }^{4}$ Fisheries and Oceans Canada, Bedford Inst. of Oceanography, B2Y 4A2 Dartmouth, Canada

The Norwegian salmon production is estimated to increase from 1.2 to 3 million tons, with a use of 3.6 million tons feed per year in 2030. A considerable amount of the feed used is released to the surrounding waters, as respiratory products, faeces and uneaten feed. To minimize waste discharges that potentially lead to degradation of the marine environment, it is suggested to cultivate extractive species in close vicinity to the fish farms in integrated multi-trophic aquaculture (IMTA). Large scale field studies were conducted to define the dynamics in nutrients released from salmon and corresponding incorporation in seaweed and bivalves at commercial Atlantic salmon farms in western Norway. The results indicate that seaweed will grow faster in immediate proximity to salmon aquaculture than in monoculture. However, the lack of enhanced growth only $200 \mathrm{~m}$ away from the farm raises the question of the possibilities for industrial up-scaling of seaweed cultivation in IMTA. The seasonal mismatch between maximum nutrient release from the salmon in late summer and early autumn and fast growth of sugar kelp from February to June addresses another important challenge for efficient IMTA design. Considering the use of filtering species, the results suggests that biomitigation of particulate wastes should focus on the benthic system in further investigations of IMTA in Norway. We will place those results in a larger context to discuss the possible application of
IMTA and advance on the development of alternative and/or adapted approaches to use of IMTA in Norwegian aquaculture, addressing spatiotemporal challenges specific for Norwegian conditions.

CELLULAR ORCHESTRATED BIOMINERALIZATION OF CRYSTALLINE COMPOSITES ON IMPLANT SURFACES BY THE EASTERN OYSTER, CRASSOSTREA VIRGINICA Mary Beth Johnstone ${ }^{1}$, Neeraj V. Gohad ${ }^{1}$, Elizabeth Falwell', Douglas C. Hansen ${ }^{2}$, Andrew S. Mount ${ }^{1}$, Karolyn M. Hansen ${ }^{3}$

${ }^{1}$ Clemson University, Department of Biological Sciences, Okeanos Research Laboratory, Clemson, SC, 29634, USA

${ }^{2}$ University of Dayton Research Institute, Nonstructural Materials Division, Dayton, OH, 45469, USA

${ }^{3}$ University of Dayton, Department of Biology, Dayton, $\mathrm{OH}$, 45469, USA

Shell formation in the eastern oyster, Crassostrea virginica, is a nanoscale process that involves both hemocytes (blood cells) and the outer mantle epithelial cells (OME). We report the secretion of an extracellular matrix (ECM) and cellular activity during shell layer formation by observing prismatic and foliated layer development on implanted metal alloy surfaces (Ti6A14V, 7075-T6 aluminum, and 316L stainless steel). It was observed that ECM walls, which surround prismatic crystals, are closely associated with the OME and appear to originate from the OME. Foliated shell formation was initially observed as an agglomeration of hemocytes on implant surfaces with subsequent formation of a thin translucent membrane. Exosomelike vesicles, some containing crystal nuclei, were deposited on the membrane and maturation of the layers resulted in the typical foliated layer shell structure. The organic and mineral phases that compose the prismatic and foliated shell layers appear to be secreted, organized, and simultaneously formed in a coordinated process resulting in production of the extraordinarily strong nanocrystalline ceramic shell.

\section{THE SLOW RECOVERY OF THE ICELAND SCALLOP (CHLAMYS ISLANDICA) FISHERY IN BREIDAFJORDUR, ICELAND \\ Jonas P. Jonasson}

Marine Research Institute, Skúlagötu 4, 101 Reykjavík, Iceland

The major Iceland scallop (Chlamys islandica) fishery in Iceland, in Breiðafjörður, collapsed in the beginning of the new millennium and has remained closed since 2004. Poor recruitment combined with intensified fishing and high natural mortality caused by protozoan infestation in adult scallops seems to have led to the collapse of the stock. Survey indices declined drastically between 2001 and 2006, to a historical minimum in 2013. Recruitment has remained poor but 
year-classes from 2010 and especially 2012 are emerging. During 2014, the traditional dredge survey was replaced with a camera survey and was stretched to new areas within the fjord. Further, a small scale fishing trial was initiated last fall on a defined area within the southern grounds with the area surveyed before and after harvest of $300 \mathrm{t}$. Scallops were found in fishable quantities in the new areas with more year-classes present than on the conventional grounds, where in many areas Asteroidea were the dominant biomass. The direct comparison between the surveys will be discussed along with future research and proposed long-term fishing trials.

TRACKING THE ABUNDANCE OF DUNGENESS CRAB MEGALOPAE IN CALIFORNIA - POTENTIAL INDEX FOR FUTURE FISHERY CATCHES

\section{Christy I. Juhasz ${ }^{1}$, L. Rogers-Bennett ${ }^{1,2}$}

${ }^{1}$ California Department of Fish and Wildlife, Bodega Marine Laboratory, 2099 Westside Road, Bodega Bay, CA, 94923, USA

${ }^{2}$ University of California Davis, Bodega Marine Lab, P.O. Box 247, Bodega Bay, CA 94923, USA

The Dungeness crab fishery of California is one of the state's oldest commercial fisheries and in 2012 and 2013 it outranked all other California fisheries in ex-vessel value averaging $\$ 87.4$ million for the two years. Historically, the fishery has been characterized by cyclical landings, however in the last ten seasons, higher than average landings have been observed especially in the central region of the state. A biological index of future fishery landings may be the number of Dungeness crab megalopae, the last larval stage before settlement, that arrive in bays and estuaries during the spring. Megalopae caught in Oregon have been positively correlated with commercial season landings three to four years later. We tracked megalopae abundance in Eureka and Bodega Bay from 2008 to 2014. Megalopae were captured in light traps overnight and enumerated daily during the spring settlement season. Marked differences were found in the total number of megalopae caught in time (year) and space (site). The carapace length of each year's cohort both within and between sites was assessed. The future goal of this work will be to examine correlations between megalopae abundance and the commercial landings three to four years later. In addition, we will identify and determine which oceanographic conditions yield higher megalopae abundances leading to strong favorable Dungeness crab recruitment into the fishery.

LOOK DEEP INTO MY SHELL: SHELL PARASITISM AND RADIOGRAPHY OF APALACHICOLA BAY OYSTERS Andrew S. Kane ${ }^{1,4}$, Ross M. Brooks ${ }^{1}$, Felipe E. Sanchez ${ }^{1}$, Jason H. Byrd $^{2}$, Rachel Touroo ${ }^{2}$, Shannon Hartsfield ${ }^{3}$, Karl E. Havens ${ }^{4}$

${ }^{1}$ University of Florida, Aquatic Pathobiology Laboratories, Department of Environmental \& Global Health, P.O. Box 110885, Gainesville, FL, 32608, USA
${ }^{2}$ University of Florida, Maple's Center for Forensic Medicine, Department of Pathology, Immunology and Laboratory Medicine, 4800 SW 35th Drive, Gainesville, FL, 32608, USA

${ }^{3}$ Shannon Hartsfield, Franklin County Seafood Workers Association, 192 Coach Wagoner Boulevard, Apalachicola, FL, 32320, USA

${ }^{4}$ Florida Sea Grant College Program, 803 McCarty Drive, Gainesville, FL, 32611, USA

Oyster health and condition assessments are part of ongoing, community-based efforts focusing on Apalachicola Bay, a heritage oyster fishery along the northern Gulf coast of Florida. Baseline and restoration monitoring research, to better understand environmental and management factors, has been in effect since the fishery decline in 2012. Assessments included observations of shell parasitism by boring clams (Diplothyra), polychaete worms (Polydora) and sponge (Cliona). Radiographic visualization provided a far more accurate assessment of prevalence and ranked severity, than direct visual observations (that typically underestimated shell parasite severity up to 10 -fold). Radiography also revealed that Polydora infection occurs primary from the shell edge, not from other external aspects of the shell. Further, size bin analyses indicated that colonization of live oysters with Polydora preceded colonization by Cliona and Diplothyra. Elevated salinity conditions, associated with drought and reduced water flow into the Bay, favor the presence of these shell parasites, weakening the live shell and making the oyster host more susceptible to predation by drills and crabs. The parasitized shell that remains on the reefs as cultch material likely degrades more quickly due to enhanced surface area. Shell parasitism and Perkinsus marinus histological observations from stained mantle tissue were positively associated with oyster height $(\mathrm{p}<0.05)$ from different sample locations within the bay. Health and condition indices, and size class-related recruitment and mortality, are discussed relative to management considerations. Support for these studies was provided, in part, through the NIEHS, Florida Sea Grant and UF IFAS.

\section{PATHOLOGY SURVEY OF RUDITAPES PHILIPPINARUM DURING THE POST-SPAWNING SEASON IN KOREA} Hyun-Sil Kang, Hyun-Ki Hong, Hee-Do Jeong, Kwang-Sik Choi

School of Marine Biomedical Science (BK21 PLUS), Jeju National University, 102 Jejudaehakno, Jeju 690-756, Republic of Korea

In 2013, pathology of Manila clams collected from 11 intertidal in Korean waters was surveyed in this study using histology. Perkinsus olseni infection prevalence assessed using RFTM ranged $96.67-100 \%$ on the west and south coast, and the intensity varied $1.00 \times 10^{6} \pm 1.72 \times 10^{5}$ to $4.87 \times 10^{6} \pm 8.43 \times 10^{5}$ cells $/ g$ gill tissue weight. Histology revealed that Perkinsus was limited to the gills and 
mantle tissues in the lightly infected clams, while $P$. olseni could be seen from all types of tissues in heavily infected. Massive hemocyte infiltration could be seen in the gills, digestive tubules, and gonads of the clams heavily infected with $P$. olseni. Sporocyst and metacecaria of Cercaria tapids and Parvatrema duboisi were observed in the gonad and mantle, with a prevalence of 3.3-23.3\%. Ricketssia-like organism and copepod was only detected in the digestive tubule with the prevalence ranging 3.3-13.3 and 3.3-10\%, respectively. Marteilioides sp. and Marteilia sp. were identified in the clams from the south coast. Histology and RFTM suggested that $P$. olseni was the main pathogen in the Manila clam populations causing inflammation and necrosis as the infection level become extreme.

THE VARIEGATED CARPET SHELL RUDITAPES VARIEGATUS (SOWERBY, 1852) AS A NEW HOST OF PERKINSUS HONSHUENSIS

Hyun-Sil Kang ${ }^{1}$, Hyun-Ki Hong', Kyung-Il Park ${ }^{2}$ and Kwang-Sik Choi $^{1}$

${ }^{1}$ School of Marine Biomedical Science (BK21 PLUS), Jeju National University, 102 Jejudaehakno, Jeju 690-756, Korea

${ }^{2}$ Department of Aquatic Life Medicine, Kunsan National University, Gunsan 573-701, Korea

Perkinsus olseni has been identified as the agent of Perkinsosis in Ruditapes philippinarum and Protothaca yesoensis in Korean waters. Recently, P. honshuensis, a new Perkinsus species has been identified in Japan, infecting Manila clam. In the present study, we surveyed on the presence of $P$. honshuensis and its co-infection with $P$. olseni in Manila clam. Manila clams were collected from 24 locations on the west, south, east coast and Jeju Island and Ruditapes variegatus was collected only from Jeju Island. RFTM, P. olseni/honshuensis-specific PCRs based on ITS, and histology was applied in the investigation. Perkinsus-like organism was found in the digestive tubule in $R$. variegates, demonstrating a typical signet ring-like appearance in histology. In RFTM, $5-20 \%$ of the $R$. variegatus formed hypnospores. In the PCRs, Manila clams from all the sampling sites yielded $P$. olseni positive amplified product, while none of the clams showed $P$. honshuensis-positive product. Accordingly, our study indicated that $P$. olseni is the sole agent of Perkinsosis in Manila clam in Korean waters, and no Manila clams are infected with $P$. honshuensis. We also confirmed for the first time $R$. variegatus as a new host of $P$. honsheuensis.

PERSPECTIVES ON MECHANISMS OF ABALONE HETEROSIS: EVIDENCE FROM PROTEOMICS APPROACH Caihuan $\mathrm{Ke}^{1}$, Guilan $\mathrm{Di}^{2}$, Weiwei You ${ }^{1}$, Xuan Luo ${ }^{1}$

${ }^{1}$ Xiamen University, College of Ocean and Earth Sciences, Xiamen 361005, PR China

${ }^{2}$ Henan Normal University, College of Fisheries, Xinxiang 453007, PR China
Precisely predicting the phenotypic changes is still a problem in heterosis studies. Protein expression patterns were compared from two hybrid practices using 2-DE and MALDI-TOF-TOF analyses: 1) interspecies hybrids between two abalone species Haliotis gigantea and $H$. discus hannai; 2) intraspecies hybrids between Japan and Taiwan population for small abalone $H$. diversicolor. Using software PDQuest, thousands of protein spots were detected, while different 2-DE image muscle protein spots displayed a mirrored relationship between parental and the hybrids. In the interspecies hybrids case, we identified 136 differentially expressed proteins involved in major biological processes including energy metabolism and response to stress. Most of the energy metabolism proteins exhibit additivity, stressinduced proteins display over-parent or mid-parent heterosis, and hybrids offspring exhibiting additivity or over-dominance accounted for $64.7 \%$. In the intraspecies hybrids case, a total of 46 gel spots were identified and a total of 15 spots matched with abalone proteins. Hybrid exhibiting additivity or overdominance accounted for $73.9 \%$ of these 46 identified proteins. Differentially expressed proteins were shown to be involved in major biological processes, including muscle contraction and regulation, energy metabolism, and stress response. These proteins exhibited additivity in their offspring. The proteins involved in stress responses included HSP Hsp70 (exhibiting overdominance in the offspring) and $\mathrm{Cu} / \mathrm{Zn}$-superoxide dismutase (exhibiting additivity). These results suggested that proteomic approach is suitable for analysis of heterosis and functional prediction of abalone hybridization.

\section{NITROGEN REMOVAL ASSOCIATED WITH OYSTER REEFS AND OYSTER AQUACULTURE}

\section{Lisa Kellogg ${ }^{1}$, Jeffrey C. Cornwell ${ }^{2}$, Michael Owens ${ }^{2}$}

${ }^{1}$ Virginia Institute of Marine Science, Rt. 1208 Greate Road, Gloucester Point, VA, 23062, USA

${ }^{2}$ UMCES Horn Point Laboratory, P.O. Box 775, Cambridge, MD, 21613, USA

Both oyster reef restoration and oyster aquaculture have been proposed as a means of mitigating eutrophication in estuarine waters. In Chesapeake Bay, interest in their capacity to remove nitrogen has increased in recent years due to EPAmandated water quality improvements that include setting total maximum daily loads (TMDL) for nitrogen and other pollutants of primary concern. Use of oysters to meet TMDL requirements will depend on their net nitrogen removal capacity and their location relative to nitrogen inputs. The three primary ways in which oysters can remove nitrogen are 1) assimilation into the tissue and shell of oysters and associated organisms, 2) long-term burial of biodeposits, and 3) conversion of particulate and dissolved nitrogen to nitrogen gas via microbially mediated nitrification-denitrification. Thus, net nitrogen removal will be 
the sum of assimilation, burial and denitrification. Recent research on these processes and how they scale with oyster biomass density and other factors will be presented. The importance of environmental setting and location relative to nitrogen inputs will also be discussed. The relative benefits of oyster reef restoration versus oyster aquaculture will also be considered.

\section{RESPONSES OF OYSTER MICROBIOMES TO HYPOXIA} Bushra Khan', Sandra M. Clinton², Timothy J. Hamp ${ }^{3}$, James D. Oliver $^{1}$, Amy H. Ringwood ${ }^{1}$

${ }^{1}$ University of North Carolina at Charlotte, Department of Biological Sciences, Charlotte, NC, 28223, USA

${ }^{2}$ University of North Carolina at Charlotte, Department of Geography and Earth Sciences, Charlotte, NC, 28223, USA

${ }^{3}$ University of North Carolina at Charlotte, Department of Bioinformatics and Genomics, Charlotte, NC, 28223, USA

Rising global temperatures and increases in hypoxic zones due to elevated water temperatures and eutrophication in estuarine ecosystems pose risks to coastal wildlife populations. One such potential impact may be changes in microbial communities which can have far reaching implications. Ecosystem engineers such as filter-feeding oysters, which are also valuable to seafood industry, are susceptible to these microbiome changes. The overall goal of our studies was to evaluate changes in oyster microbiomes related to dissolved oxygen stress. The microbial composition of hepatopancreas tissues of eastern oysters, Crassostrea virginica exposed to hypoxic conditions from both laboratory and $\mathrm{NC}$ field studies was evaluated using Automated Ribosomal Intergenic Spacer Analysis (ARISA) as well as standard culture methods. There were significant increases in microbial abundance, especially in facultative anaerobes, and principle component analyses indicated distinct bacterial subgroups related to hypoxic exposures. Both field and laboratory data indicated that hypoxic stress was associated with a significant increase in oyster microbiome diversity. Our studies support the hypothesis that unstressed oysters sustain a relatively small resident microbiome that can be perturbed by hypoxia. Changes in microbiome could impact overall oyster health and fitness as well as increase the incidence of pathogenic microbes, posing increased risks to both wildlife and human consumers of oysters.

EFFECTS OF HYPOXIA ON METAL BIOAVAILABILITY AND TISSUE DAMAGE IN EASTERN OYSTERS AND RIBBED MUSSELS

\section{Bushra Khan, Amy Ringwood}

University of North Carolina at Charlotte, Department of Biological Sciences, Charlotte, NC, 28223, USA
Estuaries support a wide variety of organisms and are exposed to multiple stressors diurnally as well as seasonally. Fluctuations in water quality parameters such as dissolved oxygen, $\mathrm{pH}$, salinity and temperature as well as heavy metal pollution from anthropogenic inputs can be challenges of living in estuaries. Interactions between multiple stressors can exacerbate oxidative stress and subsequent tissue damage in estuarine organisms. Metals, like copper and manganese, exist in the environment complexed with organic or inorganic matter, and their bioavailability may be affected by water quality parameters. The overall goal of these studies was to evaluate the effects of cyclical and continuous hypoxia on metal uptake in tissues of two bioindicator bivalvesCrassostrea virginica, eastern oysters, and Geukensia demissa, ribbed mussels. We hypothesized that hypoxia increases metal bioavailability from estuarine sediments, resulting in increases in metal concentrations in digestive gland and gill tissues. Tissue metal concentrations were measured using atomic absorption spectrophotometry after exposure to contaminated sediments under different hypoxic conditions to assess metal uptake. A lipid peroxidation assay was used to evaluate tissue damage, and total glutathione concentrations were quantified to examine antioxidant status. Tissue metal concentrations were found to be affected by hypoxia which also resulted in elevated tissue damage and altered antioxidant status. Interestingly, there were significant species-specific differences in sensitivity and metal accumulation patterns. Determination of the sensitivities and vulnerability of two ecologically important bivalve species to hypoxia and bioavailability of metals is critical for predicting impacts on estuarine ecosystems.

EXPANDING LIVING SHORELINES THROUGH STAKEHOLDER-DRIVEN SITE SELECTIONS FOR INTERTIDAL OYSTER REEF BUILDING IN THE ACE BASIN NERR, SOUTH CAROLINA, USA

Peter Kingsley-Smith, Benjamin Stone, Blaik Keppler, John Leffler

Marine Resources Research Institute, South Carolina Department of Natural Resources (SCDNR), 217 Fort Johnson Road, Charleston, SC, 29422-2559, USA

Efforts to establish "living shorelines" on U.S coastlines through the creation of intertidal oyster reefs, often in conjunction with habitat restoration and enhancements projects, are increasing. These living shorelines are seen by many as a preferred alternative to more engineered approaches to armoring shorelines against erosion and sea level rise. Typically these oyster reef-building projects begin with the identification of a problem, such as habitat loss through erosion. Researchers and resource managers with high levels of expertise in their respective fields then identify specific locations, processes, and strategies to address this problem. Lacking in this approach are the local knowledge and concerns 
of stakeholders who have personal, recreational, or commercial interests in the adversely affected areas. In 2012, the SCDNR secured substantial funding from the NERRS Science Collaborative project to expand living shorelines in the ACE Basin NERR through the creation of intertidal oyster reefs. This project adopted an alternative restoration roadmap that more holistically engaged stakeholders. Project staff assembled a large group of community leaders, scientists, and property managers to better define the problem for the community and identify sites that represented their priorities for restoration. Stakeholders then worked side-by-side with researchers and managers to evaluate and prioritize sites, and subsequently allocate oyster reef restoration resources among sites. Having met initial project goals to protect shoreline, create new habitat, and increase coastal resiliency, the project culminated in a public event that incorporated additional reef-building, education, and outreach activities to further enhance stewardship of natural resources across the region.

GENOTYPE AND PHENOTYPE IN A CHANGING OCEAN: CAN STANDING GENETIC VARIATION IN STRESS RESPONSES RESCUE MUSSEL POPULATIONS FROM THE NEGATIVE IMPACTS OF CLIMATE CHANGE?

Sarah E. Kingston, Jenna Watling, Benjamin Eisenberg, David Carlon

Bowdoin College Biology Department and Coastal Studies Center, 6500 College Station, Brunswick, ME, 04011, USA

As physical and chemical features of the ocean change in response to the changing climate, marine calcifiers face the biochemical and physiological challenge of maintaining calcium carbonate shell structure in a more acidic environment. A key component to understanding organismal response to this multifactorial stressor is linking underlying genetic variation to phenotypic variation in stress response. We take advantage of the genomic gradient across the blue mussel hybrid zone (Mytilus edulis and Mytilus trossulus) in the Gulf of Maine to link genetic variation with variance in calcification rates in response to lower $\mathrm{pH}$, higher temperatures, and reduced food availability. Intertidal blue mussels were collected from midcoast Maine up to Cobscook Bay and subjected to a 14-day exposure in a laboratory common garden treatment of climate stress $\left(20^{\circ} \mathrm{C}, \mathrm{pH} 7.8\right.$, and low food availability: water filtered to $5 \mathrm{uM})$. The control treatment simulated ambient Harpswell Sound summer conditions $\left(17^{\circ} \mathrm{C}, \mathrm{pH} 8.1\right.$, and high food availability: $0.34 \mathrm{~mL} /$ individual/day Shellfish Diet 1800). Interestingly, the climate stress treatment rendered significantly greater variation in calcification rates (change in buoyant weight) than the control treatment, while the means did not vary significantly. The calcification rate phenotypes are now being linked to underlying genomic variation through a next generation sequencing-based genome reduction SNP assay and genome-wide association survey.
VARIATION IN NATIVE OYSTER (OSTREA LURIDA) PERFORMANCE BETWEEN AND WITHIN TWO RESTORATION SITES IN SAN FRANCISCO BAY

Stephanie L. Kiriakopolos ${ }^{1,2}$, Chela J. Zabin ${ }^{1,3}$, Lara Martin ${ }^{1,4}$, Rena Obernolte ${ }^{5}$, Robert Abbott ${ }^{6}$, Edwin D. Grosholz ${ }^{1}$

${ }^{1}$ University of California Davis, 3114 Wickson Hall, Davis, CA, 95616, USA

${ }^{2}$ San Francisco State University, Romberg Tiburon Center, 3150 Paradise Drive, Tiburon, CA, 94920, USA

${ }^{3}$ Smithsonian Environmental Research Center, Romberg Tiburon Center, 3150 Paradise Drive, Tiburon CA, 94920, USA

${ }^{4}$ San Francisco Bay National Estuarine Research Reserve, Romberg Tiburon Center, 3150 Paradise Drive, Tiburon, CA, 94920, USA

${ }^{5}$ Isla Arena Consulting, USA

${ }^{6}$ ENVIRON, 201 California, San Francisco, CA, 94111, USA

The native oyster Ostrea lurida is increasingly an important focus for shoreline restoration. Nearly all oyster restoration projects involve hard substrate addition, but few projects quantitatively assess the relative performance of oysters on different substrate types and configurations. Native oyster populations were compared on five substrate types deployed in summer 2012, at two restoration sites (San Rafael and Hayward) in San Francisco Bay. Substrates consisted of molded "baycrete" (cement and locally dredged shell) structures: 1) modular interlocking blocks, 2) stacked small domes, 3) single large domes, 4) large segmented domes and 5) stacks of Pacific oyster shell in mesh bags. Oyster demographics data was collected three times a year through 2014 , measuring variables on north versus south facing surfaces and at three tidal elevations. Between sites, a large variation in oyster recruitment and percent cover was found, however, within sites, oyster densities differed little by substrate type. At San Rafael, a significant effect of tidal elevation and aspect was found; oyster numbers were consistently highest on north, vertical faces at lower tidal elevations, suggesting a thermal stress influence on oyster recruitment and/or survival. Initial recruitment at Hayward also followed this general pattern, but oyster densities were greatest at higher tidal elevations, a result of predation by the introduced oyster drill Urosalpinx cinerea at lower elevations. (Drills are not present at San Rafael site.) These results suggest that key stressors for oysters vary between sites, even within one estuary, and modifying the configuration and placement of restoration substrates could enhance oyster performance.

\section{SURFCLAM SURVEY STRATEGIES}

\section{Alexa Kretsch, Dan Georgianna, Kevin D.E. Stokesbury}

University of Massachusetts-Dartmouth, School for Marine Science and Technology, 200 Mill Road, Suite 325, Fairhaven, MA, 02719, USA

Integrating two or more fishery resource surveys can increase and diversify the data available to stock assessment scientists and 
managers. The Atlantic surfclam (Spisula solidissima) has been surveyed by dredge by the Northeast Fisheries Science Center (NEFSC) since 1965. The NEFSC dredge survey conducts tows from Cape Hatteras to the Gulf of Maine and Georges Bank and collects data on number and weight of clams per tow on a 1.5 nautical mile transect. However, many areas remain unexplored due to gear, time, and funding limitations. The School for Marine Science and Technology (SMAST) video survey collects images of the seafloor, four quadrats per station on a 1.5-3 nautical mile grid. These images do not identify clams by sight, but record the holes of burrowing species, such as the surfclam and the ocean quahog (Arctica islandica). This paper assessed the feasibility of video survey data providing accurate, fine-scale data on surfclam presence and density. A laboratory experiment had reviewers differentiate between images of surfclam and ocean quahog siphon holes to see if they can be positively identified in video images. Surfclam density was estimated using the video and the dredge surveys off New Jersey and there was no significant correlation between results of the two surveys. It is unlikely that an optical survey will be able to assess this burrowed species.

\section{A SYSTEM-LEVEL MODELING TOOL TO PREDICT CAR- RYING CAPACITY AND ECOSYSTEM IMPACTS IN LARGE-SCALE, BIVALVE-DOMINATED AGRO-ECOSYS- TEMS: APPLICATION TO NORTHERN QUAHOG ( = HARD CLAM; MERCENARIA MERCENARIA) AQUACULTURE IN CHERRYSTONE INLET, VA}

Michael Kuschner, Mark Brush

Virginia Institute of Marine Science, College of William and Mary, Gloucester Point, VA, 23062, USA

With the recent growth of the hard clam aquaculture industry, sites of intensive aquaculture have emerged as large-scale agroecosystems where the success of aquaculture production is dynamically linked to ecosystem function. Large scale clam aquaculture operations are associated with a range of potential positive and negative feedbacks related to nutrient dynamics, water and sediment quality, proliferation of macroalgae, and carrying capacity. Quantitative modeling tools are needed to support system-level planning related to site selection, scale of operations, production capacity and ecosystem function. A model was developed for Cherrystone Inlet, VA, where one-third $\left(1.9 \mathrm{~km}^{2}\right)$ of the sub-tidal bottom area is held as 37 separate, private shellfish leases with an estimated 100-150 million cultured clams. A reduced complexity estuarine ecosystem model has been coupled with a hard clam energetics and growth model and a watershed loading model. The model facilitates ecosystem-based management and enables regional spatial planning in a full ecosystem context, through coupled simulations of aquaculture activities, land use changes, nutrient loading, climate change, and estuarine response. Model simulations suggest that current clam densities are near the ecological carrying capacity with food limitation occurring during the growing season (March-October). Further increases in clam densities are predicted to result in a reduction of clam growth rates and increased time to harvest. Simulations are ongoing to predict system response to changes in land use and climate. The completed model will be served online for direct use by local managers and industry personnel.

\section{ROLE OF A NOVEL PLASMA IRON BINDING PROTEIN IN EASTERN OYSTER HOST DEFENSE AGAINST PERKINSUS MARINUS}

Jerome La Peyre ${ }^{1}$, Sandra Casas ${ }^{1}$, Jaren Lee, Julie Gauthier ${ }^{2}$, Jean-Philippe Beguel ${ }^{1}$, Qinggang Xue ${ }^{1}$

${ }^{1}$ Department of Veterinary Science, School of Animal Sciences, Louisiana State University Agricultural Center, Baton Rouge, LA, 70803, USA

${ }^{2}$ Loyola University, New Orleans, LA, 70803, USA

Depriving invading microbes of iron essential for their growth is a well-known innate defense mechanism of vertebrates but very little is known about possible iron withholding system in invertebrates including oysters. Segon is a recently characterized metal binding protein that is secreted by oyster hemocytes and make up about $20 \%$ of plasma protein. Its high association with iron suggests a potential role in oyster host defense. Eastern oysters were therefore exposed to iron carbonyl ( 5 or $20 \mathrm{mg} / \mathrm{L}$ daily) and challenged with Perkinsus marinus and then sampled to measure segon expression along with whole organism responses (mortality, condition), tissue responses (histopathology alterations), cellular responses (hemocyte density, viability, phagocytic capacity, reactive oxygen species production) and subcellular responses (dominin expression, lysosomal stability, superoxide dismutase activity, glutathione and HSP70 protein concentrations, lipid peroxidation) in relation to iron concentrations and $P$. marinus infection intensities. Results indicated no change in segon transcription levels but significant differences in other host responses after iron exposure. Surprisingly although mortality was greater in oysters receiving iron, P. marinus infection intensity was highest in oysters not exposed to iron. A follow-up study using oysters naturally infected with $P$. marinus in the field and exposed to $5 \mathrm{mg} / \mathrm{ml}$ iron carbonyl also suggested that the increase $P$. marinus in hemocytes of individual oysters was not as pronounced in oysters exposed to iron carbonyl. Our results suggest that iron carbonyl exposure might be detrimental to P. marinus in oysters.

\section{THE COMBINED EFFECTS OF OIL AND SALINITY ON EASTERN OYSTERS}

Jerome La Peyre, Sandra Casas, Qinggang Xue, Scott Miles

Department of Veterinary Science, School of Animal Sciences, Louisiana State University Agricultural Center, Baton Rouge, LA, 70803, USA

Following the Deepwater Horizon oil spill, we determined the responses of caged eastern oysters deployed in the field using a suite 
of biological effects measurements (biomarkers) in relation to polyaromatic hydrocarbons (PAHs) concentrations. To better interpret our field results it was essential to assess salinity as a potential confounding factor. In summer and winter, eastern oysters were therefore exposed to oil contaminated sediments at a salinity of 10 and 20 in the laboratory and then sampled to measure whole organism responses (mortality, condition), tissue responses (histopathology alterations), cellular responses (hemocyte density, viability, phagocytosis capacity, reactive oxygen species production) and subcellular responses (lysosomal stability, HSP70 proteins, superoxide dismutase activity, glutathione concentration, lipid peroxidation) and PAHs concentrations. Our results indicated that significant differences in biomarker responses were between salinity treatments with limited effects of oilcontaminated sediment exposure.

ELEVATED $p \mathrm{CO}_{2}$ CAUSES SLOWED GROWTH IN JUVENILE BLUE CRAB (CALLINECTES SAPIDUS) FROM THE PATUXENT RIVER, CHESAPEAKE BAY

Hillary Lane ${ }^{1}$, Kennedy T. Paynter ${ }^{1,2}$, Thomas J. Miller ${ }^{1}$

${ }^{1}$ University of Maryland Center for Environmental Science, Chesapeake Biological Laboratory, 146 Williams Street, Solomons, MD, 20688, USA

${ }^{2}$ University of Maryland, Department of Biology, College Park, MD, 20740, USA

Future climate scenarios predict decreases in oceanic $\mathrm{pH}$ over the next century, largely due to the absorption of increased levels carbon dioxide $\left(\mathrm{CO}_{2}\right)$ in the atmosphere as a result of the burning of fossil fuels. Calcifying invertebrates, which depend on specific conditions of carbonate chemistry for many biological processes, may be especially impacted by declines in ocean $\mathrm{pH}$. Here we report the results of a study on the impact of acidified conditions on the growth of blue crab, Callinectes sapidus, juveniles. Crabs were kept individually in one of three acidification treatments (800,

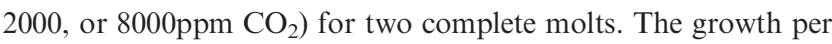
molt (GPM, mm) and intermolt period (IMP; days and degree days) were determined for each crab and analyzed by $\mathrm{pCO}_{2}$ treatment. Although $\mathrm{pCO}_{2}$ treatment had no impact on the GPM $(\mathrm{P}>0.05)$, crabs in the highly acidified treatment $(8,000 \mathrm{ppm}$ $\mathrm{CO}_{2}$ ) had significantly longer IMP than crabs in the ambient treatment (800ppm $\mathrm{CO}_{2} ; \mathrm{P}<0.05$ ). This observed increase in IMP indicated that crabs in the highly acidified treatment grew $10 \%$ slower than crabs in ambient treatment. Crabs that grow slower may have higher mortality because they will reach size refuge from predation later in life, these crabs may have less energy available to allocate to reproduction, and slowed growth may also cause crabs to recruit to the fishery when they are older. Additional work is necessary to fully understand both the physiological and ecological impacts of acidification on juvenile crab in the Chesapeake Bay.

\section{SELECTIVE BREEDING OF PACIFIC OYSTERS IN A CHANGING ENVIRONMENT \\ Chris Langdon, Evan Durland, Blaine Schoolfield}

Coastal Oregon Marine Experiment Station and Department of Fisheries and Wildlife, Hatfield Marine Science Center, 2030 OSU Drive, Newport, OR, 97365, USA

The Molluscan Broodstock Program (MBP) was initiated in 1996 at Oregon State University (OSU) with the goal of improving yields (growth and survival) of Pacific oysters (Crassostrea gigas) on the West Coast, USA, through genetic selection. During MBP's history, culture conditions in both commercial hatcheries and in the natural environment have undergone considerable variation over different time scales, ranging from long-term cycles (PDO and ENSO) in oceanic conditions to shorter-term seasonal and tidal effects. Although positive realized heritabilities for improved yields have been found against this backdrop of environmental variability, they are typically small and not consistent across cohorts and grow-out conditions. MBP has attempted to meet this challenge of variable culture conditions by selecting for generalist families that perform well across a range of culture conditions, but recent results suggest that such generalists are less evident than previously observed. Selectively breeding oysters will be discussed in the context of variable culture conditions, global warming and ocean acidification.

\section{SEQUENCE ANALYSIS OF THE PHAGE INFECTING THE WITHERING SYNDROME RICKETTSIA REVEALS A NOVEL BACTERIOPHAGE}

Stanley A. Langevin ${ }^{1}$, Colleen A. Burge ${ }^{2,3}$, Lisa M. Crosson ${ }^{2}$, Samuel J. White ${ }^{2}$, Carolyn S. Friedman ${ }^{2}$

${ }^{1}$ University of Washington, Department of Microbiology, 960 Republican Street, Seattle, WA, 98109, USA

${ }^{2}$ University of Washington, School of Aquatic and Fishery Sciences, Box 355020, Seattle, WA, 98195, USA

${ }^{3}$ University of Maryland Baltimore County, Institute of Marine and Environmental Technology, 701 East Pratt Street, Baltimore, MD, 21202, USA

Hyperparasitism of bacterial pathogens by phages can alter the relationship between the bacterium and its host. Reduced pathogenicity and associated mortality in abalone infected with bacteriophage-infected Candidatus Xenohaliotis californiensis, the rickettsial (RLO) agent of withering syndrome (WS), was observed. A first step in better understanding phage-bacterium dynamics is developing diagnostic tools. In order to sequence and characterize a novel bacteriophage associated with the RLO responsible for WS in black abalone, we prepared metagenomic sequencing libraries from genomic DNA extracted from experimentally infected black abalone. To deplete the highly abundant black abalone DNA and enrich for the bacteriophage sequences, the genomic DNA libraries were normalized using hydroxyapatite chromatography normali- 
zation. Normalized libraries were individually barcoded and sequenced on an Illumina MiSeq platform. Raw sequence reads were processed using Virominer, an automated metagenomic analysis software tool designed to assemble and identify divergent microbe genomes. One single phage-like contig (35.7 Kb in length) was de novo assembled and identified in both infected black abalone samples. This highly divergent genome sequence had closest homology with a bacteriophage associated with abalone shriveling syndrome. 32 ORFs showed overlapping homology with the abalone shriveling syndrome-associated virus ranging from $17 \%$ to $71 \%$, demonstrating our bacteriophage is genetically distinct from any known phage in the NCBI database. The phage-like sequences represented a significant portion of the total reads sequenced ( $\sim 2$ million/12 million PE reads; $17 \%)$ and we obtained $94,000 \times$ coverage depth across the phage-like genome. We are developing quantitative PCR and in situ hybridization assays to detect and quantify this phage.

\section{EFFECTS OF SALTWATER INTRUSION ON NATIVE AND} EXOTIC APPLE SNAILS, POMACEA PALUDOSA AND $P$. INSULARUM

Susan Laramore $^{1}$, Naomi Huntley ${ }^{2}$

${ }^{1}$ Florida Atlantic University, 5600 US 1 North, Fort Pierce, FL, 34946, USA

${ }^{2}$ Michigan State University, 220 Trowbridge Rd., East Lansing, MI, 48824, USA

The Florida snail kite (Rostrhamus sociabilis plumbeus) is an endangered species. The Florida apple snail, Pomacea paludosa makes up $90 \%$ of its diet. Three species of exotic apple snails were introduced to Florida from 1950-1980. Pomacea maculata is the most widespread, and is now considered established. Due to a decline in the native snail's population, brought on by drought and saltwater intrusion, the snail kite's nesting sites have shifted from the Everglades to the Kissimmee chain of lakes, where large numbers of $P$. maculata occur. This poses a problem because exotic snails reach a larger size, making it difficult for the kites to handle. The South Florida Water Management District (SFWMD) is concerned as to how predicted increased salinity might affect remaining $P$. paludosa populations. This study examined the effects of salinity $(0.5,2,4,8,12)$ on survival and growth over eight weeks. Neither species survived exposure to 12 ppt. Pomacea paludosa showed higher survival at 8 ppt: $95 \%$ versus $67 \%$ (week 4 ); $31.5 \%$ versus $0 \%$ (week 8 ); survival at 4 ppt was lower (77\%) for both species and no differences were seen at 2 or $0.5 \mathrm{ppt}$. Growth was significantly lower for both species at $8 \mathrm{ppt}$. Survivors were returned to $0.5 \mathrm{ppt}$ and at week 20 were similar in size to the controls. This study suggests that $P$. paludosa can withstand higher salinities, for a longer period, than $P$. maculata and that decreased growth is a short-term reaction to exposure.
QUANTIFYING PHYSIOLOGICAL RESPONSE OF EASTERN OYSTER, CRASSOSTREA VIRGINICA, TO REGIONAL ENVIRONMENTAL VARIABILITY USING THE DYNAMIC ENERGY BUDGET THEORY

Romain Lavaud ${ }^{1,2}$, Megan LaPeyre ${ }^{3}$, Sandra M. Casas Liste ${ }^{4}$, Cédric Bacher ${ }^{5}$, Jerome LaPeyre ${ }^{4}$

${ }^{1}$ Louisiana State University, LSU AgCenter, School of Renewable Natural Resources, Baton Rouge, LA, 70803, USA

${ }^{2}$ LEMAR (UMR 6539), Institut Universitaire Européen de la Mer, Université de Bretagne Occidentale, Rue Dumont d'Urville, Place Nicolas Copernic, 29280 Plouzané, France

${ }^{3}$ Louisiana State University, U.S. Geological Survey, Louisiana Cooperative Fish and Wildlife Research Unit, School of Renewable Natural Resources, LSU AgCenter, Baton Rouge, LA, 70803, USA

${ }^{4}$ Louisiana State University, LSU AgCenter, School of Animal Sciences, Baton Rouge, LA, 70803, USA

${ }^{5}$ Laboratoire d'écologie benthique, IFREMER Centre Bretagne, ZI de la Pointe du Diable, CS 10070, 29280 Plouzané, France

The eastern oyster, Crassostrea virginica, is an economically important species for U.S. fisheries which also provides significant ecological benefits within coastal areas, including provision of hard structure habitat, water filtration, and shorelines protection. The northern coast of the Gulf of Mexico (nGoM) supports over $90 \%$ of U.S. C. virginica production. Globally, shellfish reefs, such as those provided by $C$. virginica in the $\mathrm{nGoM}$ are considered imperiled with over $85 \%$ of historic reefs considered to be functionally extinct. While $C$. virginica within the $\mathrm{nGoM}$ continue to support a viable oyster industry and provide a critical estuarine habitat, changes in environmental conditions from human and natural events are impacting their survival, reproduction and growth. The use of quantitative and dynamic ecophysiological models, such as the Dynamic Energy Budget theory (DEB) provides an explicit understanding of factors controlling life history traits of organisms, especially in changing environments. The aim of this study is to parameterize a DEB model for the eastern oyster from the nGoM in order to provide accurate predictions of growth, survival and various physiological processes. The two key environmental parameters basically used as forcing variables in DEB models are temperature and food availability. However, in the nGoM, C. virginica are also influenced by highly variable salinity and we attempted to integrate the effects of salinity on the physiology of the oyster. The model was calibrated using literature data and ecophysiological experiments conducted in the lab at Louisiana State University at the range of $\mathrm{nGoM}$ temperature $\left(16-30^{\circ} \mathrm{C}\right)$ and salinity (3-25) conditions. The model will be validated through field monitoring studies and an application to other populations along its distribution range (East and Northeast coast of the U.S.). 


\section{DOES THE FLIP BAG IMPROVE OYSTER GRADE AND QUALITY?}

Dale Leavitt, Matthew Griffin

Roger Williams University, 1 Old Ferry Road, Bristol, RI, 02809, USA

Half-shell oyster marketing relies, to some degree, on the grade of the oyster produced and how that factor enhances or detracts from the attractiveness and value of the product. Conventional grading of oysters is based either on the morphometrics of the shell (length, width and depth) or the mass of soft tissue contained within the shell. Common practice in oyster farming is to tumble the oyster occasionally to enhance the formation of the "cup" by breaking off the newly formed "bill" thereby generating a better shaped and more marketable oyster. More recently, a flip bag system, designed to tumble the oyster with every tidal cycle, has been developed on the West Coast that is suggested to produce a better grade and more marketable oyster. In this study, flip bags were evaluated in terms of the grade and meat quality of the eastern oyster (Crassostrea virginica) when compared to a traditional rack and bag culture system. Applying standards of shell shape (width to length and depth to length ratios) and edible tissue content (soft tissue dry weight and condition index), it was demonstrated that the flip bag system produces a different shaped oyster with higher meat content than a conventionally farmed oyster. The application of flip bag culture yields a slower growing, but higher grade, oyster compared to rack and bag culture, with a large volume of edible tissue, which may lend itself to a higher market value.

\section{MORTALITY ASSESSMENT OF GRAY MEAT DISEASE IN SEA SCALLOPS (PLACOPECTEN MAGELLANICUS) \\ Megan Levesque, Kevin Stokesbury, Susan Inglis}

University of Massachusetts Dartmouth School of Marine Science and Technology (SMAST), 200 Mill Road, Fairhaven, MA, 02719, USA

Normal sea scallop adductor muscles are creamy white in color and firm. Sea scallops that are infected by the gray meat disease are characterized by small, dark, stringy, flaccid and overall low quality meat. The occurrence of gray meat scallops is becoming more common on George's Bank in parts of the rotational management areas of Closed Area I (CAI), Closed Area II (CAII), and the Nantucket Lightship Closed Area (NLCA) and has become a concern for the industry. Gray meat disease information is nascent. It is unknown whether a sea scallop with a gray adductor muscle can recover to white meat quality and be valuable to the fishery again. Understanding whether gray meat disease scallops can recover or it represents a chronic progressive disease is critical for resource management. To assess the mortality of gray meat scallops, a lab experiment was conducted maintaining gray meat disease sea scallops under optimal growing conditions. This experiment showed high mortality among the gray meat sea scallop compared to white meat scallops under the same conditions. This indicates that gray meat disease is a chronic condition. Future work will involve protozoan intensity measurements to better understand the progression of the disease as well as the transfer from one individual to another.

\section{AQUACULTURE APPROACH TO OYSTER NITROGEN REMOVAL: IS THERE A SWEET SPOT OF NITROGEN INPUT?}

Jeffrey Levinton ${ }^{1}$, Daria Sebastiano ${ }^{2}$, Michael Doall ${ }^{1}$, Shauna Kamath $^{1}$

${ }^{1}$ Department of Ecology and Evolution, Stony Brook University, Stony Brook, NY, 11794, USA

${ }^{2}$ School of Marine and Atmospheric Sciences, Stony Brook University, Stony Brook, NY, 11794, USA

The mitigating effects of natural oyster mounds and maricultured oysters have been discussed extensively, including influences of oysters on microbially mediated nitrogen transformation and the potential for removal of human-influenced nitrogen inputs by oyster growth and harvest. We considered the potential for nitrogen sequestration during growth into soft tissue and shell of Crassostrea virginica. We considered harvest in the highly eutrophic Jamaica Bay, (N input $\sim 5.8 \times 10^{6} \mathrm{~kg} \mathrm{~N} \mathrm{y}^{-1}$ ) with Great South Bay - suburban and medium impacted ( $\mathrm{N}$ input $\sim 8.5 \times 10^{5} \mathrm{~kg} \mathrm{~N} \mathrm{y}^{-1}$ ), both on the south shore of western Long Island, New York. In the extreme case of $50 \%$ of total suitable habitat coverage, oysters in Jamaica Bay could extract ca. $61 \%$ of nitrogen input, and 47 percent, if 5000 acres were covered. While impressive, the oysters could not be sold for food and the cost of such a plan would be prohibitive. In Great South Bay, aquaculture over 5000 acres would take up $148 \%$ of the nitrogen input, which is encouraging since aquaculture leases are beginning to be awarded in this bay and most waters are clean enough for harvest and human consumption. Our results suggest that an aquaculture-harvest method might be very useful to compensate for the sort of diffuse nitrogen input that is common in mildly eutrophic estuaries where nitrogen input is intermediate and where sewer systems are not present. In highly urbanized estuaries, chemical removal of nitrogen within sewer systems is the preferable remedy.

\section{TRANSCRIPTOME ANALYSIS OF THE RESPONSE TO AIR EXPOSURE AND COLD STRESS BY THE EASTERN OYS- TER}

\section{Cui Li, Ximing Guo}

Rutgers University, Haskin Shellfish Research Laboratory, Institute of Marine and Coastal Sciences, 6959 Miller Avenue, Port Norris, NJ, 08349, USA

As sessile organisms adapted to life in estuaries and intertidal zones, oysters can tolerate highly variable environmental condi- 
tions. The eastern oyster, Crassostrea virginica, is particularly resilient, being able to cope with wide fluctuations in temperature $\left(0-49^{\circ} \mathrm{C}\right)$ and salinity $(5-40)$, and survive months out of water. To understand the molecular mechanism of the stress response of the eastern oyster, transcriptome changes induced by air exposure and cold stress were studied. Eastern oysters were cultured at four conditions: $22^{\circ} \mathrm{C}$ seawater $(22 \mathrm{SW}), 22^{\circ} \mathrm{C}$ air exposure $(22 \mathrm{AE}), 5^{\circ} \mathrm{C}$ seawater (5SW), and $5^{\circ} \mathrm{C}$ air exposure (5AE). On day seven, oysters were sampled, RNA was extracted and prepared for pair-end 100 bp RAN-seq with Illumina HiSeq 2000. Clean reads (248 million) were assembled into 138,995 unigenes with a N50 of $1333 \mathrm{bp}$, revealing 667,152 single-nucleotide polymorphisms and 62,868 indels. Compared with the $22 \mathrm{SW}$ control, 5SW, $5 \mathrm{AE}$ and $22 \mathrm{AE}$ induced differential expression of 419, 486 and 693 genes, respectively. Air exposure at $5^{\circ} \mathrm{C}$ appeared less stressful as only 165 genes were differentially expressed between 5SW and 5AE. Air exposure at $22^{\circ} \mathrm{C}$ was highly stressful and induced up-regulation of 484 genes and down-regulation of 209 genes. Genes coding for heat shock proteins, inhibitors of apoptosis, tumor necrosis factors (TNF) were highly up-regulated, and genes coding for cytochrome P450, glutathione S-transferase, transcription factors and transforming growth factors were down-regulated. Our analyses indicate that genes related to protein folding and processing, TNF signaling, xenobiotic metabolism, MAPK signaling, apoptosis and antioxidation pathways are important in eastern oyster's response to environmental stress.

\section{CAN YOU HEAR ME NOW?: SOUNDSCAPE MANIPULA-} TION ENHANCES LARVAL OYSTER SETTLEMENT

\section{A. Lillis, D. Eggleston, D. Bohnenstiehl}

North Carolina State University, Department of Marine, Earth and Atmospheric Sciences, Center for Marine Sciences and Technology, Raleigh, NC, 27695, USA

Marine benthic ecosystems, and efforts to restore them, depend critically on the influx of larval settlers. For some marine species, underwater soundscapes may influence larval recruitment to suitable adult habitats; however, the significance of such acoustic cues is rarely tested. We found that subtidal oyster reefs (Crassostrea virginica) in coastal North Carolina, USA show distinct acoustic signatures compared to adjacent off-reef soft bottom habitats, characterized by consistently higher levels of sound in the 1.5-20 $\mathrm{kHz}$ range. Manipulative laboratory playback experiments found increased settlement in larval oyster cultures exposed to oyster reef sound compared to unstructured soft bottom sound or no sound treatments. In field experiments, ambient reef sound produced higher levels of oyster settlement in larval cultures than did off-reef sound treatments. Using a series of soundscape manipulation experiments, we then show for the first time that the free-swimming larvae of an estuarine invertebrate can respond to habitat-related acoustic cues. Across multiple experiments, settlement by oyster larvae was significantly higher on collectors exposed to the sounds associated with oyster reef habitats compared to no-sound controls. Given the importance of habitat selection in the lifecycle of oysters and other reef-building organisms, understanding the drivers of the settlement process is critical to successful prediction of population dynamics, and informs marine conservation and aquaculture programs.

\section{MUSSEL FARMING IN STATE AND FEDERAL WATERS OF SOUTHERN NEW ENGLAND \\ Scott Lindell' ${ }^{1}$ Bill Silkes², Adam Silkes ${ }^{2}$, Mason Silkes², David Bailey ${ }^{1}$ \\ ${ }^{1}$ Scientific Aquaculture Program, Marine Biological Labora- tory, Woods Hole, MA, 02543, USA \\ ${ }^{2}$ American Mussel Harvesters, 165 Tidal Drive, N. Kingston, RI, 02852, USA}

There is a growing market for fresh mussels ( $\sim \$ 40$ million/yr) in the United States, of which $>90 \%$ is presently served by farmed imports from Canada. Domestic wild supply is limited. New England shellfish farmers could capitalize on the many advantages they have over Canadian producers including faster growth to market size, shorter distance to market, and better meat yield for prime summer markets. This presentation will address the opportunities, constraints and the progress to date for creating a vibrant mussel farming industry in Southern New England (SNE) waters, including new permits in Federal waters.

MULTI-CROPPING SEAWEED, GRACILARIA TIKVAHIAE, WITH OYSTERS FOR NUTRIENT BIOEXTRACTION AND SEA VEGETABLES IN WAQUOIT BAY, MASSACHUSETTS Scott Lindell', Jang Kim², Emma Green Beach', David Bailey', Morgan Beals ${ }^{1}$, Charles Yarish ${ }^{3}$

${ }^{1}$ Scientific Aquaculture, Marine Biological Laboratory, Woods Hole, MA, 02543, USA

${ }^{2}$ University of Connecticut, Department of Marine Sciences, Stamford, CT, 06901, USA

${ }^{3}$ University of Connecticut, Department of Ecology and Evolutionary Biology, Stamford, CT, 06901, USA

The native red seaweed, Gracilaria tikvahiae, was cultivated on an oyster farm to investigate the dual purposes of nutrient bioextraction and production of edible sea vegetables. Gracilaria was grown in the spring of 2012 and 2013 to facilitate a first planting in June. Gracilaria was planted at two sites (with and without oyster cages), at two depths $(0.2 \mathrm{~m}$ and $0.6 \mathrm{~m})$, at two stocking densities (20g bundles planted every $10 \mathrm{~cm}$ and $20 \mathrm{~cm}$ ), and at two harvest intervals (every 2 weeks and every 4 weeks). Gracilaria grew very well at both locations. Best yields per unit area have been found at the shallower depth $(0.2 \mathrm{~m})$, at high stocking density $(10 \mathrm{~cm})$ and at two-week harvest intervals. Approximately 
$50 \mathrm{~kg}$ of $\mathrm{N}$ per growing season (June to October) can be removed by Gracilaria in hypothetical one hectare farm with $3 \mathrm{~m}$ spacing between longlines was estimated. However, fouling (primarily tunicates) were a problem, especially when Gracilaria was cultivated longer than two weeks. Freshwater treatment helped to overcome the fouling problem. The $\mathrm{N}$ removal capabilities of cultured seaweeds and oysters, and harvest of wild seaweed were compared. A market demand for quality sea vegetables at $\$ 16 /$ pound is demonstrated.

GENETIC POPULATION STRUCTRE OF THE OLYMPIA OYSTER, OSTREA LURIDA, IN SOUTHERN CALIFORNIA JoAnne Linnenbrink, Ryan Walter, Danielle Zacherl, Doug Eernisse

California State University Fullerton, Dept. Biological Science, Box 6850, Fullerton, CA, 92834, USA

Restoration of the historically impacted Olympia oyster (Ostrea lurida) is ongoing all along the West Coast but in southern California, where restoration is underway, there is almost no information regarding its genetic structure. Project managers cannot yet effectively allocate time, money, and resources to best harness existing genetic variation. We aim to provide baseline genetic structure estimates for remnant Olympia oyster populations in eight southern California estuaries. Previous mitochondrial DNA sequence comparisons have not yet revealed enough variation to evaluate whether or not oyster populations are structured, so we have used more variable microsatellite markers. Our null hypothesis was that southern California populations have some genetic structure and that genetic similarity will reflect geographic proximity, as expected for isolation-by-distance (IBD) models. Results to date for Alamitos and Newport Bay have not found significant pairwise $\mathrm{F}_{\mathrm{ST}}$ values. STRUCTURE analysis supports $\mathrm{K}=1$, suggesting that Alamitos and Newport Bay are members of a larger population. Despite this lack of overall population genetic structure so far, DAPC results indicate site-specific variation that could be due to private alleles in Alamitos and Newport samples. Population genetic characterization will enhance the opportunities for restoration managers to successfully restore this and possibly other native estuarine species.

GENETIC VARIATION IN SUSCEPTIBILITY OF THE EASTERN OYSTER TO PERKINSUS MARINUS

Ming Liu, Susan Ford, David Bushek, Ximing Guo

Rutgers University, Haskin Shellfish Research Laboratory, Institute of Marine and Coastal Sciences 6959 Miller Avenue, Port Norris, NJ, 08349, USA

Perkinsus marinus, a protozoan parasite of the eastern oyster Crassostrea virginica, has spread to much of the US Atlantic
Coast causing serious damages to oyster populations. To understand the host-parasite interactions that are key to epizootic outbreaks, genetic variation in eastern oyster's susceptibility to $P$. marinus was investigated by challenging families of oysters with different dosages of the pathogen. Two sets of forty families (4 Dams X 10 Sires) were produced: one from a selected resistant population (SP) and the other from a wild Delaware Bay population (WP). Larvae from the 40 families were pooled, and oysters were cultured in a sanctuary. One-year old oysters were challenged with $P$. marinus at $100,1,000$ or 10,000 parasites per oyster. Samples were taken on Day 45 postchallenge when no mortality was observed. On Day 56 when mortality began, all SP oysters were fixed. Dead oysters in the WP group were collected to Day 92 when all live oysters were sampled. Infection intensity was determined using quantitative PCR, and all oysters were assigned to families with nine microsatellites. Results showed that infection intensity is positively correlated with parasite dosage at early but not late stages, indicating re-infection events. At the same dosage and early stages, WP oysters were infected faster and at higher intensities than SP oysters, possibly due to genetic differences from selection. Some SP families appeared more susceptible at early stages, but at Day 56, heritability in infection intensity was small, suggesting genetic variation in $P$. marinus susceptibility is limited.

INVASION AND MORPHOLOGICAL VARIATION OF THE NON-INDIGENOUS BARNACLE CHTHAMALUS CHALLENGERI (HOEK, 1883) IN YANGSHAN PORT AND ADJACENT SEA AREAS

Yan Liu ${ }^{1}$, Junzeng Xue ${ }^{1,2}$, Junda $\mathrm{Lin}^{2}$, Huixian $\mathrm{Wu}^{1}$

${ }^{1}$ Key Laboratory of Exploration and Utilization of Aquatic Genetic Resources, Shanghai Ocean University, Ministry of Education, Shanghai 201306, P. R. China

${ }^{2}$ Department of Biological Sciences, Florida Institute of Technology, Melbourne, FL, 32901, USA

Invasive species generally possess unique characteristics that allow them to establish and spread in new habitats. Successful invaders must resist both physical and physiological stress associated with the changing environment. A common littoral barnacle, Chthamalus challengeri Hoek, 1883 (Crustacea, Cirripedia), which is native to Japan, South Korea and northern China, has become established in the high-littoral zone adjacent to Yangshan Port, Shanghai, China. A comparison of the morphology of Chthamlus species from Zhoushan archipelago with previous description indicates the occurrence of $C$. challengeri. The new immigrant becomes a dominant species in certain high-intertidal habitats of the area adjacent of Yangshan Port. C. challengeri was found in some of sampling sites in Zhoushan in 2010, however, it has dispersed to all the 11 sampling sites in 2012. Densities of $C$. 
challengeri had increased over 10 times in the last 2 years, with the highest mean value reached $39,533 \pm 6,243$ ind. $/ \mathrm{m}^{2}$ in the new habitat. The specific ratio of both operculum area $(S a)$ /base area $(S A)$ and average height of parietal plates $(H)$ /length of base $(L)$ revealed that $C$. challengeri displays morphological plasticity to resist stronger currents in the new habitats.

\section{P-AMINOSALICYLIC ACID (PAS) REVERSES NEURO- TOXIC EFFECTS OF MANGANESE ON DOPAMINE POST-SYNAPTIC RECEPTORS}

Kurt Loney-Walsh, Loren Dubose, Margaret A. Carroll, Edward J. Catapane

Biology, Medgar Evers College, 1638 Bedford Avenue, Brooklyn, NY, 11225, USA

Manganese (Mn), a neurotoxin causing Manganism, disrupts dopamine (DA) neurotransmission. The neurotoxic mechanism of action is not fully resolved. Effective clinical treatments are lacking. Reports postulate Mn toxicity is more related to dysfunction of DA D2 receptors (D2DR) than degeneration of neurons. Cilia of gill lateral cells of Crassostrea virginica are innervated by cilioinhibitory DA nerves. Mn treatment blocks effects of DA and postsynaptic DA receptors in lateral cells are D2 type. Applying p-aminosalicylic acid (PAS) with Mn prevented the toxic effect. These results prompted the hypothesis that PAS could reverse Mn neurotoxicity when applied after $\mathrm{Mn}$. To test this $C$. virginica were treated for up to 3 days with $\mathrm{Mn}(500 \mu \mathrm{M})$ followed by 5 more days with PAS $(500 \mu \mathrm{M})$. Gills were excised, fixed, exposed to $1^{\circ}$ antibodies against D2DR and FITC-linked $2^{\circ}$ antibodies, paraffin embedded, sectioned at $10 \mu \mathrm{m}$, and then visualized on a fluorescence microscope. Fluorescence intensity was quantified using Image J software from NSF. Results showed fluorescence intensity in animals treated with $\mathrm{Mn}$ had a progressive decrease in fluorescence of up to $40 \%$ less than non-Mn treated controls. Animals treated with PAS after Mn did not show reduced fluorescence, indicating PAS reversed the Mn induced loss of post-synaptic D2DR. This immunohistological study shows a positive correlation between the loss of D2DR fluorescence in Mn treated animals vs. controls. It also shows PAS effectively reversed the toxic effects of Mn on D2DR even after 3 days of Mn treatment.

EFFECTS OF OCEAN ACIDIFICATION ON SOUTHERN TANNER CRAB LARVAE: CARRYOVER EFFECTS FROM OOGENESIS AND EMBRYOGENESIS ARE STRONGER THAN DIRECT EFFECTS

\section{W. Christopher Long, Katherine Swiney, Robert Foy}

Alaska Fisheries Science Center, Resource Assessment and Conservation Engineering Division, Kodiak Laboratory, 301 Research Court, Kodiak, AK, 99615, USA
Ocean acidification, a decrease in the $\mathrm{pH}$ of the oceans with increasing atmospheric and oceanic $\mathrm{CO}_{2}$ concentrations, is expected to affect many marine animals. We determined the effects of ocean acidification on the larvae of the economically important southern Tanner crab, Chionoecetes bairdi. By using wild-brooded larvae and holding females in treatment $\mathrm{pH}$ for two brooding cycles over two years and using the resulting larvae, we were able to detect carryover effects from oogenesis and embryogenesis. Ovigerous females were held at three $\mathrm{pH}$ conditions: $\sim 8.1$ (Ambient), 7.8, and 7.5. When larvae hatched, they were used in experiments examining the effects of ocean acidification on starvation-survival, morphology, condition, and calcium/magnesium content. Exposure to acidified conditions at the larval stage alone had minimal effects on the larvae, likely because larvae are adapted to living in an environment with large pH swings. However, exposure during oogenesis and embryogenesis resulted in significant carryover effects; larvae differed morphometrically, were smaller, and had lower calcium and magnesium contents. They also had a lower metabolic rate as evidenced by longer starvation-survival times. Although the larval phase itself is resilient to low $\mathrm{pH}$, carryover effects are likely to have a negative effect on larvae in the wild. These results, combined with negative effects of ocean acidification at other life history stages indicate that ocean acidification may have a significant effect on the southern Tanner crab populations and fisheries in the near future.

\section{ZEBRA MUSSELS AS BIOINDICATORS OF HABITAT QUALITY IN THE GREAT LAKES, USA}

Matthew Lowder ${ }^{1}$, Bushra Khan', Annie Jacob, Kimani Kimbrough ${ }^{2}$, Ed Johnson', Amy Ringwood ${ }^{1}$

${ }^{1}$ University of North Carolina at Charlotte, Department of Biological Sciences, Charlotte, NC, 28223, USA

${ }^{2}$ NOAA, Center for Coastal Monitoring and Assessment, 1305 East West Highway, Silver Spring, MD, 20910, USA

Bivalve molluscs are valuable bioindicator species due to their sessile lifestyle and filter-feeding capabilities, and their tendency to accumulate contaminants in their tissues. Therefore, bivalves can provide spatial and temporal insights for identifying habitat stress, both environmental and anthropogenic. NOAA's Mussel Watch program has been involved in monitoring contaminants in aquatic systems and expanded to include areas-of-concern under the Great Lakes Restoration Initiative. In these studies zebra mussels (Dreissena polymorpha) were used as bioindicators to evaluate the potential toxicity and bioavailability of contaminants from Great Lakes sites in Lake Michigan and Lake Erie in collaboration with NOAA. NOAA staff collected and dissected zebra mussel tissues from various sites, and some samples were processed for contaminants (PCBs, metals, etc.) by NOAA, while some 
samples were sent to our laboratory for cellular biomarker analyses. For these studies, the cellular biomarkers that were evaluated in D. polymorpha were a tissue damage assay, lipid peroxidation (LPx), and an antioxidant status assay, glutathione (GSH). Sites which had low levels of GSH also tended to have high levels of LPx, suggesting that conditions that reduce antioxidant capacity increase the potential for oxidative damage. These studies indicate that while zebra mussels are typically branded as an invasive species, they may also be a valuable bioindicator species to assess and make comparisons of habitat quality and ecosystem health in the Great Lakes and other freshwater locales.

\section{INCREASED SEDIMENT DENITRIFICATION AT AN OFF- BOTTOM OYSTER AQUACULTURE SITE IN CHESA- PEAKE BAY}

Abby Lunstrum, Ashley Smyth, Karen McGlathery

Virginia Institute of Marine Science, College of William and Mary, P.O. Box 1346 Gloucester Point, VA, 23062. USA

"Nutrient bioextraction" using bivalve aquaculture is recently being considered as a tool to mitigate coastal nutrient pollution. While nutrients removed via shellfish harvest are relatively easily calculated, potential denitrification in sediment impacted by aquaculture activities remains poorly quantified. We measured net denitrification and nutrient fluxes from sediment in an offbottom oyster farm (rack and bag cultivation of Crassostrea virginica) in a Chesapeake Bay tributary. Using the $\mathrm{N}_{2}$ :Ar method, we found higher rates of denitrification both under and near oyster racks relative to a nearby bare sediment site. However, rates at all sites were low, and within or near the detection limit of the mass spectrometer. Nitrate $\left(\mathrm{NO}_{3}\right)$ fluxes were low and addition of $\mathrm{NO}_{3}$ increased net denitrification, indicating that denitrification at the site is $\mathrm{NO}_{3}$ limited.

\section{IDENTIFICATION OF LARVAL AND POST-LARVAL BIVALVES: A MONOGRAPH IN PROGRESS Richard Lutz}

Department of Marine and Coastal Sciences, Rutgers University, New Brunswick, NJ, 08901, USA

The larval and early post-larval stages of 54 species of bivalves were cultured by a spectrum of investigators over the past 25 years. Fifty of these species were from shallow coastal and estuarine habitats along the east coast of the U.S. and include most of the commercially important bivalves in these environments. Specimens were sampled at intervals ranging from daily to weekly, depending upon the growth rates of the various stages; preserved in $95 \%$ ethanol; and subsequently treated with a $5 \%$ solution of sodium hypochlorite to remove the soft tissues. Disarticulated valves are in the process of being photographed using a variety of scanning electron microscopes, taking care to ensure that $\mathrm{X}$ and $\mathrm{Y}$ dimensions of known spheres are equal and that all points along the commissure of each shell valve are in the same plane of focus prior to photographing. Six photographic plates of the scanning electron micrographs of a gradual sequence of larval and post-larval stages are being prepared to document the shape of the left and right valves of each shell stage, as well as details of the hinge structures of the provinculum. The estimated resulting $300+$ plates will be included in a monograph that will be authored by the myriad of individuals who cultured the larval and post-larval bivalve stages and it is anticipated that the tome will serve as an invaluable guide for the identification of larval and post-larval bivalves from a wide spectrum of coastal and estuarine habitats.

\section{DISEASE ECOLOGY OF THE BLUE CRAB AND ITS PAR- ASITE, HEMATODINIUM PEREZI, IN THE MARYLAND AND VIRGINIA COASTAL BAYS}

\section{Kristen Lycett, Joseph Pitula}

University of Maryland Eastern Shore, 2113 Carver Hall, Princess Anne, MD, 21853, USA

The genus Hematodinium is a dinoflagellate parasite known to infect a number of crustacean species worldwide, resulting in revenue loss for these major fisheries. Throughout the disease systems associated with Hematodinium, seasonal cycles in infections and high mortality rates have been observed, but the environmental presence of this parasite and its role in disease transmission remain a mystery. In conjunction with the National Park Service and the Maryland Department of Natural Resources, we are conducting a long term study monitoring $H$. perezi in blue crabs, Callinectes sapidus, within the Maryland and Virginia coastal bays. This work utilizes molecular techniques to identify parasite DNA in environmental samples and crab hemolymph. Previous work in this system has shown infections peaking in the fall with no observable infections during the late-winter and early-spring. Contrary to this, H. perezi was detected in the water column as early as February and have detected a $15 \%(\mathrm{n}=$ 26) infection rate in crabs during the month of April. Over the course of this study, hotspot sites with elevated detection rates of environmental $H$. perez $i$ were also observed, and preliminary qPCR data suggests that the environmental detection may be underestimated by less sensitive endpoint PCR techniques. By modeling the environmental presence of this parasite, as well as monitoring infection rates within the host population, we hope to create an ecosystem based understanding of this disease system which will allow for prediction of seasonal and yearly variations in host infections and mortality. 
A CRYPTIC INFESTATION OF CONCERN: A BLOODSUCKING ECTOPARASITIC SNAIL, EVALEA TENUISCULPTA, INFESTS WILD AND AQUACULTURED RED ABALONE IN CALIFORNIA

Athena Maguire $^{1,2}$, Karina Nielsen ${ }^{2,4}$, Laura Rogers-Bennett ${ }^{1,3}$

${ }^{1}$ California Department of Fish and Wildlife, USA

${ }^{2}$ Sonoma State University, 1801 East Cotati Avenue, Rohnert Park, CA, 94928, USA

${ }^{3}$ University of California Davis, 2099 Westside Road, P.O. Box 247, Bodega Bay, CA, 94923, USA

${ }^{4}$ San Francisco State University, 3152 Paradise Drive, Tiburon, CA, 94920, USA

Blood-sucking parasitic gastropods in the family pyramidellidae can have significant effects on mollusk fisheries impacting; shell formation, growth, mortality, and transmission of disease. Pyramidellids are found in multiple shellfisheries, as they are parasites of clams, mussels, scallops, oysters, and abalone, however due to the parasites small size $(>5 \mathrm{~mm})$ and cryptic nature, many pyramidellid species are understudied or overlooked. The presence of pyramidellid snails, Evalea tenuisculpta, on red abalone, Haliotis rufescens, in northern California was documented. Red abalone form the basis of an economically important aquaculture industry, recreational fishery, and are also important herbivores in subtidal marine communities. More than $40 \%$ of the red abalone $(n=1960)$ examined from 18 sites in California, in and outside aquaculture, were infected with these small ectoparasitic snails. Infected red abalone had an average of three parasites (range 0-278), each averaging $4.8 \mathrm{~mm}$ in length (range 1.0 to $9.8 \mathrm{~mm}$ ) on their shell. In aquaculture, the largest known E. tenuisculpita specimen in its family at $9.8 \mathrm{~mm}$ was documented and these larger snails lay more eggs than smaller snails. Parasitic snails were found to lay at least one egg mass every three days (average 360 eggs per mass). At $12^{\circ} \mathrm{C}$, larvae hatch into swimming feeding veligers after 14 days. Higher temperatures shorten the larval duration. The infection rates, parasite loads, and reproductive potential of this snail, suggest additional investigations need to be conducted on the basic biology, virulence, and ecology of this host-parasite relationship.

COMPARING VIDEO SURVEY SEDIMENT AND JUVENILE SEA SCALLOP OBSERVATIONS WITH A MODIFIED SLED DREDGE

Richard Malloy Jr., Kevin D. E. Stokesbury, N. David Bethoney, Susan Inglis

University of Massachusetts Dartmouth School of Marine Science and Technology (SMAST), 200 Mill oad, Fairhaven, MA, 02719, USA

The U.S. Atlantic sea scallop (Placopecten magellanicus) resource has been video-surveyed for over a decade. These data have been used in many different ways, including the creation of sediment maps and as an input into the scallop stock assessment. However, a consistent criticism of the video survey is the lack of physical samples. Physical samples taken in conjunction with the video survey could confirm sediment classifications and juvenile scallop detection. To address these specific issues, we modified a New Bedford style dredge by reducing the ring size, and added sediment traps, lights and cameras. During two survey trips on Georges Bank, we deployed the modified dredge and the video survey pyramid, successfully collecting sediment and scallop samples at twenty six different sites. Video footage of small scallops evading the dredge and low catch of scallops $<40 \mathrm{~mm}$ shell height suggest that the high resolution images taken by the video survey better quantify the amount of small scallops on the sea floor. Average sediment type was similar between dredge and video methods, but the presence of larger substrate types was more frequently observed by video. Both techniques have their advantages and it may be that a combination of the two provides the best estimates.

EVALUATION OF THE QUANTIFICATION OF VIBRIO PARAHAEMOLYTICUS AND VIBRIO VULNIFICUS IN OYSTER HOMOGENATES USING DUPLEX QUANTITATIVE PCR ANALYSIS

Kathryn Markey, Whitney Jaillet, Roxanna Smolowitz

Roger Williams University, 1 Old Ferry Road, Bristol, RI, 02809, USA

To evaluate the relative quantity of Vibrio parahaemolyticus (Vp) and Vibrio vulnificus (Vv) in enriched oyster homogenates a duplex quantitative PCR (qPCR) method develop in the Aquatic Diagnostic Lab (ADL) was used. In 2014, oyster samples from two local oyster farms (one in RI and one in MA) were processed using samples of 10 grams of enriched homogenate from pools of 10 oysters. Samples from 3 local raw bars ( 2 in MA and 1 in RI) were also sampled during the summer of 2014. All samples were processed using traditional 3-tube MPN. All samples were also cultured using TCBS and Vibrio CHROM agar plates to verify the presence of $\mathrm{Vp}$ and $\mathrm{Vv}$ in the samples. Additionally, some samples were evaluated with full MPN-qPCR analysis. Some samples showed inconstancies among the 3-tube MPN, plate culturing and the molecular analysis. Bacterial colonies from samples not amplifying in the duplex qPCR for Vp and Vv were sequenced to determine the identification of the bacterial species. Data shows that other species of bacteria aside from $\mathrm{Vp}$ and $\mathrm{Vv}$ grow in the 3-tube MPN. Data from the molecular analysis of the 10 gram samples along with MPN-qPCR data will be shared from select sample sets. 
PREVALENCE, INTENSITY, AND MOLECULAR DETECTION OF THE TREMATODE PROCTOECES MACULATUS IN MYTILUS EDULIS

Kelly N. Markowitz, Jason D. Williams, Maureen K. Krause

Department of Biology, Hofstra University, Hempstead, NY, 11549, USA

The digenetic trematode, Proctoeces maculatus (Looss 1901), is a pervasive parasite of numerous mollusc and fish species. Infections of sporocyst stage Proctoeces maculatus are predominately found in the mantle tissue of molluscan hosts such as Mytilus edulis. Although it is not well studied, it has been suggested that infection by this trematode may contribute to mussel mortality. The purpose of this study was to assess the prevalence and intensity of $P$. maculatus parasitism in mussels from several sites along coastal Long Island, NY, and from a few sites further north along the New England coast. Additionally, we wanted to develop a species-specific molecular assay to detect these trematode parasites in mussel tissue. We sequenced a region of the 18S rDNA and used this to develop a molecular assay for detection of P. maculatus. Overall the results from microscopic and molecular detection of the parasite suggest that trematode intensity is much greater than previously reported. Parasitization of the mantle tissue may reach 350 sporocysts $/ 100 \mathrm{~mm}^{2}$ in some mussel populations. Even when there is no evidence of either live sporocysts or cercaria, remnant sporocysts are often found in mussels. Climate change may be contributing to a northern range expansion for this parasite, as they are found in mussel populations from New England, with potential impacts on mussel aquaculture.

A SIMULATION MODEL TO EVALUATE THE EFFICIENCY OF ADAPTIVE CLUSTER SAMPLING

Jesse A. Marks, Robert T. Leaf

University of Southern Mississippi, Gulf Coast Research Laboratory, 703 East Beach Drive, Ocean Springs, MS, 39564, USA

In this study we describe an alternative sampling design to the commonly used sampling methods stratified and simple random sampling: adaptive cluster analysis (ACS). Through simulation modeling and application to long-term spatial distribution data, we show that adaptive cluster sampling designs can be an efficient alternative to traditional sampling schemes. Adaptive sampling methods are generally employed for estimating the population of organisms that are rare and display clustered or contagious distributions on some scale. The objectives of this study were to determine if, and under what circumstances, adaptive cluster sampling designs were more efficient than traditional sampling procedures. The Hansen-Hurwitz estimator is used to calculate the population total and the population variation. A simulation model was developed to understand the strengths and biases of adaptive cluster sampling methods relative to a standard simple random sampling approach. We investigated how: (1) modifying the sampling characteristics; and (2) alterations in simulated landscapes with different levels of clustering (aggregation) effected absolute population density estimations when using an adaptive cluster sampling algorithm. A variance ratio of the population estimates was used as a measure of relative efficiency. Adaptive cluster sampling was found to be more efficient than simple random sampling when the populations were sufficiently rare and clustered, as it was designed for. We use the results of the simulation model to understand how adaptive cluster sampling designs can be used to understand the spatial and temporal dynamics of eastern oyster populations in the Chesapeake Bay.

\section{RANGE EXTENSION OF MIKROCYTOS MACKINI, AGENT OF DENMAN ISLAND DISEASE, TO TOMALES BAY, CALIFORNIA, USA \\ Blythe C. Marshman, James D. Moore, James P. Snider}

California Department of Fish and Wildlife, Bodega Marine Laboratory, Bodega Bay, CA, 94923, USA

Denman Island disease is an infectious disease of oysters caused by the protozoan parasite Mikrocytos mackini. The disease, which is often characterized focal green lesions on the surface of the mantle, labial palps, and adductor muscle, is caused by an intracellular infection of vesicular connective tissue, leading to tissue necrosis. Mortality rates resulting from outbreaks of the disease have been reported as high as $35 \%$, although these high mortality rates are not common in all areas where the disease has been established. The pathogen was first discovered in Pacific oysters (Crassostrea gigas) in British Columbia in the 1960s and was subsequently observed in Kumamoto Oysters (Crassostrea sikamea) in Humboldt Bay in 2011. Using archived, pooled labial palp tissue collected from 60 C. sikamea in February 2012, we discovered the first incidence of the pathogen in Tomales Bay and the second in the state of California through polymerase chain reaction (PCR). Although gross observations of these oysters did not indicate the presence of the characteristic lesions, histological samples collected concurrently from the same individuals has found the presence of $2-3 \mu \mathrm{m}$ intracellular protozoa in vesicular connective tissue, which is conclusive for M. mackini infection. Initial DNA sequence analysis indicates the presence of $M$. mackini SSU rDNA. C. gigas samples collected simultaneously from the same area failed to show the presence of the pathogen via PCR, suggesting that $C$. sikamea within Tomales Bay may be a more susceptible host.

\section{REPRODUCTIVE BIOLOGY OF RED DEEP-SEA CRABS (CHACEON QUINQUEDENS) IN THE MID-ATLANTIC BIGHT \\ Stephanie Martinez-Rivera, Bradley Stevens \\ University of Maryland Eastern Shore, Princess Anne, MD, 21853, USA \\ Red deep-sea crabs (Chaceon quinquedens), an epibenthic brachyuran of the family Geryonidae, can be found from Nova}


Scotia to Florida, at 200-1800 m depths and at water temperatures between $5-8^{\circ} \mathrm{C}$. Chaceon quinquedens support a small but valuable federally-managed fishery in the Mid-Atlantic and southern New England. Red crabs are a data poor fishery; major uncertainties exist about their stock status and management due to insufficient data on their biology, abundance, growth, age, or reproduction. The objective of this study was to determine frequency of reproduction and size at $50 \%$ sexual maturity $\left(\mathrm{SM}_{50}\right)$ for males and females. Red crabs were collected in the Mid-Atlantic Bight in January of 2011 and 2012, and July of 2013 aboard NOAA research vessels, and July 2014 aboard commercial vessels. Crabs were measured and sexed, and gross morphology was recorded including the presence, size and color of ovaries and external eggs. Histological analysis was used to study gonad development, by examining the presence of spermatophores in males, and oocytes in females. Microscopy and image analysis was used to establish the gonad condition of each specimen. Results suggest that red crabs have a biennial reproductive cycle. This new information on reproduction and sexual maturity of the red crabs is vital for developing appropriate management strategies.

IS THERE A RELATIONSHIP BETWEEN CONDITION INDEX OF THE BLUE MUSSEL, MYTILUS EDULIS, AND LEVEL OF PARASITIC TREMATODAL INFECTION?

Chris Materna, M. Victoria Agnew, Kathryn Markey, Roxanna Smolowitz

Roger Williams University, 1 Old Ferry Road, Bristol, RI, 02809, USA

This study explores the correlation between blue mussel, Mytilus edulis, population's parasitic trematodal infections and significant mortality events by examining the relative abundance of trematodes to overall health of $M$. edulis evidenced by condition index. Samples were taken from three wild sites and two cultured stocks, once a month from May through September, in Narragansett Bay, Rhode Island. Samples were divided into three different size classes, $<30 \mathrm{~mm}, 30-45 \mathrm{~mm}$, and $>45 \mathrm{~mm}$. The prevalence of trematodes were observed for individuals larger than $45 \mathrm{~mm}$ by squash preparations and were given a subjective rating (1-4) based on the abundance of trematodes present. Individuals' gender was noted based on the gonadal material present in the squash preparation. The prevalence of trematodes was compared with a general evaluation of the mussel population's overall health by using two condition index formulas. One formula compares the dry tissue weight with the dry shell weight. The second evaluation consisted of the dry tissue weight compared with the difference in live weight and dry shell weight. The data gathered during this study allowed for month to month comparisons to determine any correlations between the prevalence and/or severity of trematodes and the condition index of a population at different points of time during the year. These data will also allow for comparison among different populations of blue mussels, wild and cultured in Rhode Island.

\section{ENVIRONMENTAL EFFECTS ON SEXUAL MATURATION OF TETRAPLOID CRASSOSTREA VIRGINICA UNDER COMMERCIAL HATCHERY CONDITIONS \\ Joseph L. Matt, Standish K. Allen Jr.}

Virginia Institute of Marine Science, College of William and Mary, P.O. Box 1346, Gloucester Point, VA 23062, USA

Commercial production of triploid Crassostrea virginica has increased steadily in Virginia over the last decade. Triploids are produced by crossing tetraploids to diploids, which makes ripe tetraploid brood stock essential to filling seed orders. The Aquaculture Genetics and Breeding Technology Center provides tetraploids, grown in various locations, to hatcheries located in numerous sites differing principally by salinity (10-30 ppt). Commercial hatcheries have reported problems conditioning tetraploid oysters at times, usually at the beginning of the season. In this project, we tried to separate the effects of grow-out conditions from those of tetraploid biology on the conditioning process. In the spring of 2013, 10 month old tetraploids and diploids were deployed to five field sites of varying salinity for about six months. In Fall 2013, 20\% of brood stock from each of the five grow-out locations were apportioned to five commercial hatcheries, also with varying salinity regimes. Tetraploids were conditioned alongside diploid controls and were qualitatively assessed for overall condition and ripeness at $6,8,10,12$, and 14 weeks after the start of conditioning. Tetraploids that over-summered and conditioned in similar salinity regimes were not in significantly better condition or riper than tetraploids from remote locations, but in all cases, tetraploids ripened more slowly than diploids, by two to four weeks, and had a lower condition rating. There was far more variability in tetraploids than the control diploids. All ripe oysters were confirmed as tetraploid by flow cytometry. Sex ratio was $3: 1$ male for diploids and 19:1 male for tetraploids.

\section{THE DENSITY OF FOOD AFFECTS THE NUMBER OF LARVAL STAGES IN BLUE CRAB LARVAE, CALLINECTES SAPIDUS}

Leah Maurer, J. Sook Chung

Institute of Marine and Environmental Technology, University of Maryland Center for Environmental Science, 701 E Pratt Street, Baltimore, MD, 21202, USA

The growth of crustaceans requires molting, a process which is repeated through the life cycle. In the blue crab, Callinectes sapidus, the completion of the life cycle involves 27-29 molting events, starting from hatching to adulthood. This includes 7 or 8 larval stages; however, there is inconsistency over the number of larval stages possibly due to stage skipping. It was hypothesized that food 
availability may affect the number of larval stages. To test this hypothesis, larvae were reared on a high density diet, similar to that of the hatchery, or a low density diet (about $50 \%$ of the high density). The number of molts per larvae and their survival were monitored daily until megalopae. Our data show that the density of food affects the number of larval stages to reach megalopae. Majority of larvae experienced 5 larval stages with a high density diet and 6 larval stages with a low density diet. Additionally, the density of food impacts the molt interval: about 7 days with a high density diet and 10 days with a low density diet. A large difference in the quality of batch of larvae (natural high mortality) produced by females was also observed. The batch showing natural high mortality had 6 larval stages even with a high density diet, indicating the importance of genetic variation. Overall, the data suggest that the density of food affects the duration and number of larval stages.

\section{EFFECTS OF A PATCHY FOOD ENVIRONMENT ACROSS} LIFE HISTORY STAGES

Michael McCann ${ }^{1}$, Dianna Padilla ${ }^{1}$, Sandra Shumway ${ }^{2}$

${ }^{1}$ Stony Brook University, Department of Ecology and Evolution, Stony Brook, NY, 11794, USA

${ }^{2}$ University of Connecticut, Department of Marine Sciences, Groton, CT, 06340, USA

Many animals experience periods of feast or famine, with major consequences for growth, survival, and reproductive fitness. For animals with complex life histories, will a major ontogentic transition, such as metamorphosis, remove the legacy of early starvation or diet variability? Or will these early stressors carry over to later stages? The effects of a constant versus a variable larval diet on the performance of the marine gastropod Crepidula fornicata were tested before and after metamorphosis. No detectable effect of a variable larval diet on either larval or juvenile responses was found. Instead, a greater overall amount of food during the larval period increased larval size and metamorphic competence. Surprisingly, there were no impacts on the juvenile stage. Differences that originated during the larval stage were removed by metamorphosis. These results suggest that some organisms may be resilient to variations in food availability and that not all early life experiences produce legacy effects. Flexibility in the timing of ontogenetic transitions should have a selective advantage in heterogeneous environments.

THE EFFECTS OF FOOD SUPPLY AND ELEVATED PCO ON THE EARLY DEVELOPMENT OF THE ATLANTIC SURFCLAM (SPISULA SOLIDISSIMA)

Daniel C. McCorkle ${ }^{1}$, Anne L. Cohen ${ }^{1}$, Lisa M. Milke ${ }^{2}$, Barbara Ramon $^{1,3}$

${ }^{1}$ Department of Geology and Geophysics, Woods Hole Oceanographic Institution, Woods Hole, MA, 02543, USA
${ }^{2}$ NOAA, National Marine Fisheries Service, Northeast Fisheries Science Center, Milford, CT, 06460, USA

${ }^{3}$ California State University - Dominguez Hills, Carson, CA, 90747, USA

Recent model simulations for the 21st century project a decline in the $\mathrm{pH}$ of western North Atlantic surface waters due to uptake of anthropogenic $\mathrm{CO}_{2}$, and a drop in net primary production (NPP) of up to $50 \%$. The corresponding changes in nearshore and estuarine waters may be comparable. We investigated the effects of ocean acidification (OA) and diminished food supply on early development of the commercially important Atlantic surfclam. Surfclam larvae were reared from four hours post-fertilization to 6 days old under a combination of three $\mathrm{CO}_{2}$ levels (ambient, 1200 and $2200 \mathrm{ppm}$ ) and two feeding rates (400 and 40,000 cells $\mathrm{mL}^{-1}$ ). By day six, elevated $p \mathrm{CO}_{2}$ had significant negative impacts on growth at both feeding rates, and the low feeding rate reduced growth at all $\mathrm{CO}_{2}$ levels. The two stressors showed no interaction - low food supply did not increase larval sensitivity to $\mathrm{pCO}_{2}$. However, well-nourished larvae reared at even the highest $p \mathrm{CO}_{2}$ grew faster than undernourished larvae reared at ambient $p \mathrm{CO}_{2}$. Similarly, the shells of high-food larvae were significantly heavier than those from low-food larvae. Elevated $\mathrm{CO}_{2}$ did not impact shell mass, and neither food nor $\mathrm{CO}_{2}$ affected larval survival. Our results confirm the impact of acidification on development of bivalve larvae, and highlight the potential for changes in food supply to offset or exacerbate the impact of $\mathrm{CO}_{2}$. Efforts to improve forecasting of near-shore OA and NPP changes over the course of this century, combined with laboratory manipulation experiments, will greatly improve projections of shellfish stocks.

\section{A MODELING APPROACH TO UNDERSTAND THE EFFECTS OF GEODUCK AQUACULTURE ON THE PUGET SOUND FOOD WEB}

P. Sean McDonald ${ }^{1}$, Bridget Ferriss ${ }^{2}$, Jonathan Reum ${ }^{2}$, Christopher Harvey $^{3}$, Glenn VanBlaricom ${ }^{4}$

${ }^{1}$ University of Washington, School of Aquatic and Fishery Sciences, Program on the Environment, Seattle, WA, 98195, USA

${ }^{2}$ Washington Sea Grant, University of Washington, Seattle, WA, 98195, USA

${ }^{3}$ Northwest Fisheries Science Center, National Oceanic and Atmospheric Administration, Seattle, WA 98112, USA

${ }^{4}$ US Geological Survey, Ecosystems Branch, Washington Cooperative Fish and Wildlife Research Unit, School of Aquatic and Fishery Sciences, University of Washington, Seattle, WA, 98195, USA

Culture operations for Pacific geoducks (Panopea generosa) in Puget Sound, Washington, entail large-scale, high-density outplanting of juvenile geoducks to intertidal habitats, installation and subsequent removal of predator exclusion structures (PVC tubes and netting), and harvest following a grow-out period of several 
years. Data since 2008 describing the direct effects of these practices on benthic flora and fauna was collected. The purpose of the present study is to examine the ecosystem-level effects of geoduck aquaculture by leveraging the five years of field-collected data to inform modeling efforts and guide model simulations. An existing, dynamic, mass balanced food web model developed within the Ecopath with Ecosim (EwE) framework has been modified to accommodate geoduck aquaculture-related questions. The model incorporates mediation functions that reflect response of key resident taxa to aquaculture disturbance and shifts in distribution of mobile species resulting from the presence of anti-predator structures. Intertidal habitat data have also been added into the model to determine spatially explicit ecosystem impacts of aquaculture. The EwE approach allows identification of data gaps related to species biomass, diet, and life history characteristics that are relevant to improving our understanding of the relationship between geoduck aquaculture and the surrounding food web. Current effort focuses on evaluating model scenarios based on previously established research priorities and new information from a stakeholder workshop organized for this specific project. Work to date is discussed as well as application of model results for improving management of geoduck aquaculture in Puget Sound.

CLAMS IN SPACE AND TIME: COMPARING ANALYTICAL METHODS FOR DETERMINING THE EFFECTS OF AQUACULTURE DISTURBANCE

\section{P. Sean McDonald ${ }^{1}$, Kirstin Holsman ${ }^{2}$, Glenn VanBlaricom ${ }^{3}$}

${ }^{1}$ University of Washington, School of Aquatic and Fishery Sciences, Program on the Environment, Seattle, WA, 98195, USA

${ }^{2}$ Joint Institute for the Study of the Atmosphere and Ocean, Alaska Fisheries Science Center, National Oceanic and Atmospheric Administration, Seattle, WA, 98115, USA

${ }^{3}$ U.S. Geological Survey, Ecosystems Branch, Washington Cooperative Fish and Wildlife Research Unit, School of Aquatic and Fishery Sciences, University of Washington, Seattle, WA, 98195, USA

Commercial culture of geoducks (Panopea generosa) initially involves large-scale out-planting of juveniles to intertidal habitats and installation of PVC tubes and netting to exclude predators and increase early survival. Subsequently these structures are removed, and once clams have reached market size, they are harvested by hand in a process facilitated by injecting large volumes of water into surrounding sediments. Each part of this culture cycle is characterized by disturbances of the local habitat. Our research group has collected data since 2008 describing the effects of planting, grow-out, and harvest at multiple ecological scales. We used a before-after controlimpact (BACI) design of paired plots within each site: a commercial culture plot and an adjacent reference area. Benthic infauna and epifauna/epiflora communities were sampled with cores. PerMANOVA and HMD analyses to date have demonstrated negligible effects to the structure and diversity of invertebrate communities resident within culture plots, although changes in abundance of some taxa have been noted with univariate analyses. The purpose of the present study is to use multivariate autoregressive state space statistical methods in order to complement previous analyses and evaluate temporal trends in community response to aquaculture-mediated disturbances. We have fit the community data to models using the Multivariate Autoregressive State-Space (MARSS) Package in $\mathrm{R}$ for time series data, and ranked candidate models using information criterion. Results of the MARSS models are compared to previous analyses and we discuss work to date as well as application of these methods for assessing aquaculture impacts more broadly.

\section{OF NEEDLES AND HAYSTACKS: HABITAT MAPPING AND CITIZEN SCIENCE TO MONITOR FOR EUROPEAN GREEN CRAB IN WASHINGTON STATE}

P. Sean McDonald ${ }^{1}$, Emily Grason ${ }^{2}$, Jeffrey Adams ${ }^{3}$, Kate Litle ${ }^{3}$

${ }^{1}$ University of Washington, School of Aquatic and Fishery Sciences, Program on the Environment, Seattle, WA, 98195, USA

${ }^{2}$ University of Washington, Biology Department, Seattle, WA, 98195, USA

${ }^{3}$ Washington Sea Grant, University of Washington, Seattle, WA, 98195, USA

The European green crab (Carcinus maenas) was first detected in Washington waters in 1998 after warm El Niño currents spread larvae of California populations as far north as Vancouver Island. Because of perceived risks to coastal resources, the green crab was designated a deleterious species in Washington State, which among other actions, mandated monitoring and control of the species in state waters. Green crab recruiting to coast estuaries failed to establish large populations, and none were found in inland waters of Puget Sound; consequently, monitoring and control efforts were curtailed. However, in 2012, Canadian wildlife officials discovered a population of green crab in Sooke Inlet near Victoria, British Columbia, well within the Strait of Juan de Fuca. The purpose of the present study is to design and implement a habitat-specific, volunteer-based monitoring program for inland waters of Washington State. To this end, we have produced a habitat suitability map for all shorelines using coarse physical, biological, and access characteristics observable in aerial and satellite imagery. Nearly 100 locations along the Strait of Juan de Fuca and Puget Sound appear to be suitable for green crab establishment. Current effort focuses on developing and testing a robust yet practical protocol for high-risk habitats. Work to date is discussed including the challenges of site prioritization and obstacles to sustaining a monitoring program for an elusive nonnative species. 
APPLICATION OF THE DYNAMIC ENERGY BUDGET THEORY TO PERNA VIRIDIS TO MODEL GROWTH AND REPRODUCTION UNDER VARIOUS ENVIRONMENTAL CONDITIONS

Katherine McFarland ${ }^{1}$, Fred Jean', Romain Lavaud ${ }^{2}$, Aswani Volety $^{1,3}$

${ }^{1}$ Florida Gulf Coast University, Department of Marine and Ecological Sciences, 10501 FGCU Boulevard South, Fort Myers, FL, 33965, USA

${ }^{2}$ LEMAR UMR 6539, Institute Universitaire Européen de la Mer, Université de Bretagne Occidentale, Rue Dumont d'Urville, Place Nicolas Copernic, 29280 Plouzané, France

${ }^{3}$ University of North Carolina Wilmington, Department of Biology and Marine Biology, 601 South College Road, Wilmington, NC, 28403, USA

As an invasive species ecological concerns have risen with regards to the spread and success of the green mussel Perna viridis throughout southeastern United States and Caribbean coastal waters. As a subtidal species the arrival to new locations often goes unnoticed until the populations have become established. The use of models allows for the prediction of areas which may be vulnerable to invasions and can serve as a proactive mitigation plan. Application of the Dynamic Energy Budget (DEB) theory provides a mechanistic framework in which the response of organisms in changing environments can be evaluated. Through the application of the DEB theory a set of parameters was estimated which accurately model the growth and reproduction of green mussels under environmentally realistic and dynamic conditions. Environmental variables, particularly food and temperature, are driving forces of both growth and reproduction and thus play an essential role in the foundation of the DEB predictions. The model was calibrated using a data set from field monitoring of growth, reproduction and energy storage throughout a two year study period to ensure realistic outputs. It was then validated using an external data set in order to assure the ability to use this information for populations across a wide geographic span simply by changing the environmental parameters. This work aims to serve as the basis for a future mitigation tool to aid in the prediction and prevention of further spread of $P$. viridis.

AGE AND TISSUE-SPECIFIC OCTOPINE DEHYDROGENASE EXPRESSION IN BAY SCALLOPS, ARGOPECTEN IRRADIANS

Alexander P. McGeough, Matthew Turner, Maureen K. Krause

Department of Biology, Hofstra University, Hempstead, NY, 11549, USA

Octopine dehydrogenase (ODH) terminates anaerobic fermentation and is an essential enzyme in the swimming escape response and recovery in bay scallops, Argopecten irradians. In scallops, the adductor muscle is divided into a large striated phasic muscle that powers swimming as well as tonic smooth "catch" muscle that maintains valve closure. Previous physiological studies found that striated muscle generally has greater ODH activity than catch muscles. Furthermore, more recent experiments demonstrate that there can be an energetic trade-off relationship between the escape response and reproductive investment. Our work examines tissue-specific expression levels of $O d h$ as well as age-related changes in $O d h$ expression among one and two-year old adult scallops. We hypothesized that $O d h$ expression would be highest in striated adductor muscle, and that expression would decrease in senescent two-year old scallops relative to one-year old adults. Our results show high $O d h$ expression in striated adductor muscle but also in other tissues including kidney tissue. There are significant differences in Odh expression between one and two-year old scallops, with a general decrease in expression in older animals. The catch muscle, however, has increased $O d h$ enzyme expression in older animals. Both transcriptional and metabolic regulation appear to contribute to the regulation of escape capacity in bay scallops.

\section{COORDINATION, COLLABORATION, AND COOPERATION: PROGRESS IN RESEARCH AND RESTORATION OF THE OLYMPIA OYSTER, OSTREA LURIDA (CARPENTER, 1864)} K. A. McGraw ${ }^{1}$ and N. Cosentino-Manning ${ }^{2}$

${ }^{1}$ NOAA Restoration Center, 1315 East West Hwy., Silver Spring, MD, 20910

${ }^{2}$ NOAA Fisheries Restoration Center/Damage Assessment, 777 Sonoma Ave, suite 219-A, Santa Rosa, CA 95404

The National Oceanic and Atmospheric Administration (NOAA) has been engaged in the restoration, conservation and scientific study of the Olympia oyster (Ostrea lurida) on the U.S. west coast since 2002. Through the NOAA Fisheries Restoration Center (RC), NOAA has advocated, financed and provided technical guidance on Olympia oyster restoration in CA, OR and WA states and has also assisted with organizing and sponsoring three Olympia oyster workshops, and helped fund publication of a special Journal of Shellfish Research volume on Olympia oysters, as well as a guide for monitoring shellfish restoration projects. For over a decade, the NOAA RC has supported over 30 grants totaling over \$ 2 million for Olympia oyster restoration-related projects. In addition, new advances in NOAA's shellfish policy via the National Shellfish Initiative, and the creation of the Washington Shellfish Initiative and the Kenneth K. Chew oyster hatchery in Puget Sound, WA, are changing how native oyster restoration and production will unfold along the west coast. The combined efforts of, and cooperation among restoration practitioners, oyster growers, scientists, federal, state and local government officials, environmental organizations, and interested citizens, are showing positive results in the restoration of the 
Olympia oyster. This dedicated session on Olympia oysters will feature presentations from all west coast states and British Columbia, Canada on many topics, including: living shorelines restoration techniques using native oysters; advances in population genetics; factors affecting reproduction, recruitment and survival; outcomes of the 2012 Washington Shellfish Initiative; comparisons of different restoration techniques; and the status of Olympia oysters in British Columbia.

THE RESPONSE OF MOLTING JUVENILE AMERICAN LOBSTER (HOMARUS AMERICANUS) TO FUTURE OCEAN ACIDIFICATION PROJECTIONS

Erin L. McLean, Brad A. Seibel, C. Tracy Shaw

University of Rhode Island, 120 Flagg Road, Kingston, RI, USA

The decrease in $\mathrm{pH}$ and concomitant increase in temperature caused by climate change are hypothesized to be detrimental to many marine animals, especially calcifying animals like the American lobster (Homarus americanus). Dealing with the effects of ocean acidification is expected to be energetically costly and could divert energy away from growth and reproduction. To investigate this hypothesis, this study monitors molting frequency in juvenile lobsters as a way to assess the fishery's future vulnerabilities to ocean acidification. Hatcheryreared lobsters were brought into the lab at five months old and kept under modified $\mathrm{CO}_{2}$ conditions (400 ppm, 1000 ppm, and $2000 \mathrm{ppm}$ ) for four months. Molt increment, the percent change in length from pre-molt to post-molt, decreased with increasing $\mathrm{CO}_{2}$, suggesting a decreased $\mathrm{pH}$ influences the amount of energy the juvenile lobster puts into molting. Additionally, the time in between molts increased with increasing $\mathrm{CO}_{2}$, suggesting that the lobsters are not recovering from molting as quickly as under control conditions. These results stand to have a far-reaching impact on the New England lobster fishery as American lobsters account for more than $80 \%$ of Maine's fishery landings and are also a crucial fishery in the other northeastern states.

IMMUNOHISTOFLUORESCENCE LOCALIZATION OF HISTAMINE AND HISTAMINE RECEPTORS IN GANGLIA AND TISSUES OF THE EASTERN OYSTER, CRASSOSTREA VIRGINICA

Ayana McLeod, Danellie Semple, Margaret A. Carroll, Edward J. Catapane

Medgar Evers College, Biology, 1638 Bedford Avenue, Brooklyn, NY, 11225, USA

Histamine (HIS), a biogenic amine serving as a neurotransmitter in nervous systems and in sensory receptors in a variety of invertebrates, rarely has been reported in bivalves. Previous results showed it is involved in sensory reception in sensory-motor integration of gill lateral cell cilia beating in the bivalve, Crassostrea virginica and used HPLC to show it present in ganglia and tissues. Those results prompted the hypothesis that HIS containing neurons and HIS receptors are present in ganglia and innervated tissue of $C$. virginica. The hypothesis was tested by immunohistofluorescence using $1^{\circ}$ antibodies to HIS and HIS receptors, and fluorescently labeled $2^{\circ}$ antibodies. Tissues were dissected, snap frozen, cryostat sectioned, fixed with EDAC (N-Ethyl-N'-(3-dimethylaminopropyl) carbodiimide hydrochloride) or paraformaldehyde, treated with blockers, and incubated with $1^{\circ}$ then $2^{\circ}$ antibodies. Whole mounts of gill and mantle also were similarly treated visualized. Results show HIS and HIS H2 receptors in visceral ganglia, gill, mantle body and sensory tentacles of mantle rim. Of particular significance is their presence in sensory tentacles as that correlates well with our previous sensory physiology studies, and their presence in gill interfilamental junctions, the physiology of which has not been well described. The project confirms the identity of HIS and H2 receptors in the nervous system and innervated organs, and coupled with our other work shows HIS to be an important endogenous biogenic amine in the bivalve $C$. virginica.

INVESTIGATING POLLUTED AREAS CLOSED TO SHELLFISHING AS POTENTIAL LARVAL SOURCES FOR FISHED POPULATIONS OF NORTHERN QUAHOGS IN NARRAGANSETT BAY, RHODE ISLAND

Jeffrey Mercer ${ }^{1}$, Dale Leavitt ${ }^{2}$, David Ullman ${ }^{3}$, Candace Oviatt ${ }^{3}$

${ }^{1}$ Rhode Island Department of Environmental Management, Fort Wetherill Office, 3 Fort Wetherill Road, Jamestown, RI, 02835, USA

${ }^{2}$ Roger Williams University, One Old Ferry Road, Bristol, RI, 02809, USA

${ }^{3}$ University of Rhode Island, 220 South Ferry Road, Narragansett, RI, 02882, USA

The Northern Quahog (Mercenaria mercenaria) is the single most valuable marine species harvested in Narragansett Bay, RI and has a history of being managed in a spatially explicit manner due to the human health hazards associated with the consumption of shellfish from polluted areas. Analysis of fisheries independent data indicate that these non-harvested contaminated areas serve as de facto marine reserves where biomass tends to accumulate. The large reproductive biomass in these polluted areas may serve as source populations for the harvested portions of the bay if there is a high degree of larval export to suitable fished habitat. Both Eulerian and Lagrangian approaches were utilized to assess the potential contribution of the closed areas to the total larval pool. A quahog specific primer of the mitochondrial COI gene and quantitative PCR (qPCR) were used to quantify larvae in plankton samples from stations throughout Narragansett Bay during the 
early-Summer spawning season. In addition, a bio-physical Larval Transport Model (LTRANS, North et al., 2011) was adapted and used to develop a larval exchange matrix for areas within Narragansett Bay. Field sampling indicates that time integrated larval abundance is many times greater within closed areas and model results show that large proportions of these larvae may be transported to productive fishing grounds. These results may be used to guide management decisions as some of the shellfish closure areas may soon meet environmental health standards with measurable water quality improvements and the accumulated reproductive biomass may be potentially open to harvest.

DEVELOPMENT OF THE RHODE ISLAND STATE SHELLFISH MANAGEMENT PLAN AND STEPS TOWARD IMPLEMENTING RECOMMENDATIONS

Jeffrey Mercer ${ }^{1}$, Dale Leavitt ${ }^{2}$, Azure Cygler ${ }^{3}$, Monique LaFrance ${ }^{3}$, Dave Beutel $^{4}$, Jennifer McCann ${ }^{3}$

${ }^{1}$ Rhode Island Department of Environmental Management, Fort Wetherill Office, 3 Fort Wetherill Road, Jamestown, RI, 02835, USA

${ }^{2}$ Roger Williams University, One Old Ferry Road, Bristol, RI, 02809, USA

${ }^{3}$ University of Rhode Island, 220 South Ferry Road, Narragansett, RI, 02882, USA

${ }^{4}$ Rhode Island Coastal Management Council, Stedman Government Center, Suite 3, 4808 Tower Hill Road, Wakefield, RI, 02879, USA

In 2013, Rhode Island began the process of developing a comprehensive, statewide Shellfish Management Plan, facilitated by URI's Coastal Resources Center. Shellfish are integral components of the RI marine ecosystem and the wild bay quahog fishery is consistently one of the most valuable fisheries in the state and the aquaculture industry has seen explosive growth in recent years, increasing in value by $1300 \%$ in the last decade. The goals of the plan included: 1) building and understanding of the economic, environmental, and cultural values of the local shellfish resources and associated industries; 2) evaluating existing and propose alternative management strategies; and 3) promoting science-based management by increasing scientific research and outreach activities. A comprehensive process was implemented that engaged all stakeholders in the plan development including, government, industry, academia, citizens, and civic and environmental organizations. Recognizing the urgency to respond to some of the issues identified through the stakeholder input process, state agencies implemented select early actions that led to improved management and communication with stakeholders. In addition, a list of 115 recommendations, to improve management of shellfish and further our knowledge of the resource through research, was developed by a number of Technical Advisory Committees. A significant challenge lays ahead in the implementation of this plan and making the extensive list of recommendations a reality. The early actions demonstrate the commitment by all to implement the SMP, however, identifying sources of funding, developing partnerships, and carrying out some of the more challenging recommendations will be a multi-year process.

EFFECTS OF DIURNAL VARIATION IN MARINE SEDIMENT CORROSIVITY ON THE NORTHERN QUAHOG (= HARD CLAM; MERCENARIA MERCENARIA): A STAGE-BASED POPULATION MODEL

Cale Miller, George Waldbusser

Oregon State University, College of Earth, Ocean, and Atmospheric Sciences, 104 COAS Administration Bldg., Corvallis, OR, 97331, USA

Anthropogenic fossil fuel emissions are increasing $p \mathrm{CO}_{2}$ in the coastal and global oceans in a process termed ocean acidification, further increasing the periods and duration of $\mathrm{CaCO}_{3}$ undersaturation and seawater corrosivity. Ocean acidification may intensify dissolution mortality pressure for calcifying organisms residing at the sediment-water interface and upper sediment layers, where remineralization of organic matter already produces states of $\mathrm{CaCO}_{3}$ undersaturation. Infaunal calcifying organisms such as the northern quahog (=hard clam) Mercenaria mercenaria are especially sensitive to $\mathrm{CaCO}_{3}$ undersaturation when they metamorphose to juveniles in the benthos. Therefore, understanding how these conditions will affect the population dynamics during this critical life stage will be essential for predicating adult poulation recruitment. We present a stage-based population model that predicts how variability in $\mathrm{CaCO}_{3}$ saturation state, settlement regime, and temperature-dependent growth rates affect post-settlement survival of juvenile M. mercenaria. Simulations cross levels of stochastic diurnal variability of $\mathrm{CaCO}_{3}$ saturation state to identify how growth and settlement patterns may overcome dissolution mortality. Model stages include seven different size classes of pediveliger and juveniles, and three magnitudes of diurnal $\mathrm{CaCO}_{3}$ saturation state variability under the same vertical shift (mean) of saturation state. Initial simulations show that fixed settlement regimes with high diurnal shifts result in greater growth rate variability and mortality. We will present our results in the context of bivalve sensitivity to ocean acidification, and of the predictive power of stage-based models to corroborate shellfish management.

\section{WESTERN BLOT IDENTIFICATION OF DOPAMINE AND GABA RECEPTORS IN GILL OF THE EASTERN OYSTER, CRASSOSTREA VIRGINICA}

Fabienne Mondelus, Beatrix Boisette, Fiana Bess, Edward J. Catapane, Margaret A. Carroll

Medgar Evers College, Biology, 1638 Bedford Avenue, Brooklyn, NY, 11225, USA

Gill lateral cells of the eastern oyster, Crassostrea virginica, are innervated by serotonin and dopamine (DA) nerves from their 
ganglia and regulate cilia beating rates. DA slows down cilia beating and serotonin speeds them up. GABA a neurotransmitter in vertebrates and many invertebrates rarely has been reported in bivalves. Previous work showed GABA is present in $C$. virginica and GABA acts as a ganglionic neurotransmitter modulating gill lateral cell cilia activity. Immunohistofluorescence was used to localize GABA receptors in ganglia and gill and identify DA receptors in gill lateral cells as D2-like (D2DR). These results prompted the hypothesis that Western Blot (WB) would verify D2DR and GABA receptors in gill. For WB gill cell lysate was prepared by in NP-40 detergent buffer containing protease inhibitor, followed by centrifuging to obtain supernatant with solubilized membrane proteins. Up to $30 \mu \mathrm{g}$ of solubilized protein was subjected to SDS-PAGE with $10 \%$ acrylamide gels and electroblotted onto nitrocellulose. D2DR and GABA receptor immunoreactivity was revealed by $1^{\circ}$ antibodies followed by HRP-conjugated $2^{\circ}$ antibodies. WB showed $70-75 \mathrm{kD}$ bands corresponding to DA D2DR and GABA RA1-6 receptors in gill. The present project confirms previous studies showing the presence of DA and GABA and furthers the understanding of their physiological roles in C. virginica.

GEOSPATIAL VARIATION OF RIBBED MUSSEL (GEUKENSIA DEMISSA) ECOSYSTEM SERVICES ACROSS THE SALT MARSH LANDSCAPE

Joshua Moody ${ }^{1}$, Danielle Kreeger ${ }^{2,3}$, Elizabeth Watson

${ }^{1}$ Haskin Shellfish Research Laboratory, Rutgers University, 6959 Miller Avenue, Port Norris, NJ, 08349, USA

${ }^{2}$ Drexel University, Department of Biodiversity, Earth and Environmental Sciences, 3245 Chestnut Street, Philadelphia, PA, 19104, USA

${ }^{3}$ Partnership for the Delaware Estuary, 110 South Poplar Street, Suite 202, Wilmington, DE, 19801, USA

Ribbed mussels are ubiquitous in Mid-Atlantic salt marshes where they help maintain clean water, improve habitat and potentially help marshes keep pace with sea level rise. In the Delaware Estuary, ribbed mussels are the functionally dominant bivalve, potentially filtering more water than all other native bivalves combined. Although abundant, their densities and demographics are not consistent across the marsh platform, affecting the distribution of mussel mediated ecosystem services. Ribbed mussel densities and seasonal clearance rates, nutrient porewater concentrations and geospatial elevation profiles were quantified in four habitats: low marsh banks along large rivers, low marsh along small creeks, and high marsh in four representative marshes. Clearance rates by mussels of natural seston were interpreted in the context of particle removal services and scaled to mussel dry tissue weights. Weight-specific ecosystem services furnished by ribbed mussels (evidenced here by bulk particle filtration) were not found to vary significantly among habitats. Mussel density and nutrient porewater did vary by habitat as did the proportion of marsh area occupied by the different habitat types. The removal and transformation rates for particulate nutrients also varied spatially across the marsh platform. Although mussels may provide ecosystem services at a similar capacity across the marsh platform, spatial differences in ribbed mussel density and habitat size leads to a concentration of ecosystem services in along tidal creeks and rivers. Hence, this spatial variation in key ecosystem services furnished by ribbed mussels can help focus conservation and restoration actions aimed at shellfish-mediated water quality enhancement.

\section{AN OXYTETRACYCLINE BATH SERIES ELIMINATES THE AGENT OF WITHERING SYNDROME, CANDID ATUS XENOHALIOTIS CALIFORNIENSIS, IN CAPTIVE ABA- LONE POPULATIONS}

James Moore $^{1,2}$, Shauna Byron ${ }^{1}$, Blythe Marshman ${ }^{1}$, James Snider ${ }^{1}$

${ }^{1}$ California Department of Fish and Wildlife, Bodega Marine Laboratory, P.O. Box 247 Bodega Bay, CA, 94923, USA

${ }^{2}$ Karen C. Drayer Wildlife Health Center, School of Veterinary Medicine, University of California, One Shields Avenue, Davis, CA, 95616, USA

Abalone (Haliotis spp.) populations are in decline due to overfishing and/or disease in regions that historically supported important fisheries worldwide. The white abalone and the black abalone are listed as endangered in the USA. Recovery plans for endangered species typically include outplanting of progeny from captive broodstock, and maintaining the health of broodstock is essential to promote gonad development and maturation. In California, USA withering syndrome (WS) is the principal disease of concern. It is caused by the gastrointestinal rickettsial bacterium Candidatus Xenohaliotis californiensis. The development of a bath method to eliminate the WS pathogen from captive abalone will be reported. A series of eight, 24-hour baths consisting of 500ppm oxytetracycline antibiotic in seawater were delivered to infected, farm-origin red abalone over a period of 21 days. Digestive gland oxytetracycline levels, pathogen DNA in feces, and pathogen presence by histology were examined for 189 days following the first bath. Survival rate and a body condition index did not differ between treated and mock-treated control groups. Mean oxytetracycline levels in treated groups reached a peak of $670 \mathrm{ppm}$ after the final bath application and remained above 100ppm through day 105. By that day onward all treated animals were negative for the WS pathogen by histology and feces from all treated tanks tested negative for its DNA. This method has been used to eliminate the pathogen in white, black, red, and pink abalone and likely can be applied to other species. Supported by NOAA and the Fisheries Branch, California Department of Fish and Wildlife. 
IS IT POSSIBLE TO ESTABLISH A SUSTAINABLE FISHERY PROGRAM IN MASSACHUSETTS FOR RAZOR CLAMS, ENSIS DIRECTUS?

\section{Nathaniel Mulcahy}

University of New Hampshire, Department of Biological Sciences, 117 Spaulding Life Sciences Building, Durham, NH, 03824, USA

While still growing, the razor clam industry in Massachusetts is, at this point, relatively small and, as yet, filled with unknowns. With the Mya arenaria population, in the greater Boston area, in rapid decline, Ensis is poised, not only as a new product with growth potential, but if sustainably managed, could save many of the harvesting and processing jobs currently at risk due to diminishing availability of $M$. arenaria. New products, however, present unique risks both environmentally and economically. The boom and bust of the short lived urchin rush of the early 1990s stands testament to the fact that solid understandings and new regulations are needed for any new species to assure that there is both possible growth potential, and that it is sustainable. Some of the species specific key components that must be in place to assure that if there is the potential for E. directus to grow as a fishery and that it can be done sustainably will be discussed.

\section{LARVAL DISPERSAL OF PANOPEA GLOBOSA FOLLOWS CLOCKWISE CURRENTS IN THE NORTHERN GULF OF CALIFORNIA}

Adrian Munguia-Vega ${ }^{1,2}$, Ignacio Leyva-Valencia ${ }^{3}$, Daniel $B$. Lluch-Cota $^{3}$, Pedro Cruz-Hernandez ${ }^{3}$

${ }^{1}$ PANGAS science coordination. Comunidad y Biodiversidad A.C., Isla del Peruano 215, Col. Lomas de Miramar, Guaymas, Sonora, CP 85448, México

${ }^{2}$ Conservation Genetics Laboratory, School of Natural Resources and the Environment, University of Arizona, BSE317, Tucson, Arizona, 85721, USA

${ }^{3}$ Centro de Investigaciones Biológicas del Noroeste, S.C., Instituto Politécnico Nacional 195, Col. Playa Palo de Santa Rita, La Paz, B.C.S. 23090, México

In the Northern Gulf of California (NGC), a counter-clockwise gyre during spring-summer is reversed to a clock-wise gyre during fall-winter, questioning how ecological processes like larval dispersal are shaped by strong asymmetric currents. Previous studies using oceanographic models to generate hypotheses of larval connectivity and population genetics studies of commercial invertebrates and fish displaying springsummer reproductive periods have suggested the presence of characteristic gradients of effective population size, larval dispersal and genetic diversity in relation to the direction of the predominant flow. Here, we tested if a species reproducing during the fall-winter phase of the gyre, the geoduck, Panopea globosa, show similar patterns but in opposite direction. Thirteen microsatellite loci were used to estimate levels of genetic diversity and evaluate genetic connectivity patterns among four exploited populations, including clams from the Pacific coast of Baja California and the NGC (San Felipe, Puerto Peñasco and Guaymas). Geoducks from the Pacific showed significant genetic differentiation from NGC populations. Gene flow and inferred larval dispersal followed the typical clockwise circulation of the NGC. San Felipe is located upstream relative to the oceanographic flow and had the largest effective population size, showed evidence of local retention of larvae, and is likely the main source of larvae to other downstream populations along the coast of Sonora. Populations in the NGC show a gradient of reduced diversity and population size along the direction of the prevailing flow. The asymmetry found in connectivity patterns suggests the management aimed to sustain or increase larval production and spillover, like no-take reserves, will be most effective at upstream populations.

MANAGING THE SUPPLY SIDE: LARVAL DISPERSAL FROM ROTATING CLOSURES IN THE ATLANTIC SEA SCALLOP (PLACOPECTEN MAGELLANICUS) FISHERY Daphne Munroe ${ }^{1}$, Zhiren Wang ${ }^{2}$, Dvora Hart ${ }^{3}$, Burton Shank ${ }^{3}$, Dale Haidvogel $^{2}$, Eric N. Powell ${ }^{4}$, John Klinck ${ }^{5}$, Eileen Hofmann ${ }^{5}$

${ }^{1}$ Haskin Shellfish Research Laboratory, Rutgers University, 6959 Miller Avenue, Port Norris, NJ, 08349, USA

${ }^{2}$ Department of Marine and Coastal Sciences, Rutgers University, New Brunswick, NJ, USA

${ }^{3}$ NMFS Northeast Fisheries Science Center 166 Water Street, Woods Hole, MA, 02543, USA

${ }^{4}$ Gulf Coast Research Laboratory, University of Southern Mississippi, 703 East Beach Drive Ocean Springs, MS, 39564, USA

${ }^{5}$ Center for Coastal Physical Oceanography, Department of Ocean, Earth and Atmospheric Sciences, 4111 Monarch Way, 3rd Floor, Old Dominion University, Norfolk, VA, 23529, USA

The Atlantic sea scallop (Placopecten magellanicus) fishery is the most valuable U.S. fishery. This fishery has shown remarkable recovery from a severely overfished state in the early 1990s, possibly due in part to rotational fishery closures. While these rotational closures were implemented to stabilize the population and protect scallop cohorts until they reached appropriate size, enhanced broodstock biomass in rotational closures may have led to elevated downstream recruitment and larval spill-over. To examine the link between increased broodstock abundance and the potential for increased recruitment downstream, we performed simulations of larval dispersal dynamics and connectivity for the scallop stock using a circulation model (ROMS) coupled to an individual-based scallop larval model and spatially-explicit distributions of spawning stock biomass from fishery resource surveys. 
Larval dispersal out of a closed area was simulated before, during and after a closure (2006-2012). Results of these targeted hindcast simulations show that larvae dispersal out of the closed areas (1) has good connectivity to other parts of the fishery, (2) recapitulates observed patterns of high recruitment following closures and (3) may rely heavily on interaction of spawn timing and annually varying oceanographic conditions on the shelf. Larval dispersal patterns provide information pertinent to scallop management decisions such as frequency and duration of closures as well as the utility of extending rotational management to the rest of the MidAtlantic Bight. Further, information about sea scallop connectivity in the Mid-Atlantic will assist development of metapopulation stock-recruit models, rather than a simple whole stock dynamic pool relationship.

SPATIAL PATTERNS IN PHENOTYPE AND ABUNDANCE OF OFFSHORE WHELK (BUCCINUM UNDATUM) IN THE MID-ATLANTIC REGION

Daphne Munroe ${ }^{1}$, Eleanor Bochenek ${ }^{1}$, Burton Shank ${ }^{2}$, Dvora Hart ${ }^{2}$, Sarah Borsetti ${ }^{1}$, Collin Dobson ${ }^{1}$, Sean Martin ${ }^{1}$, Joseph Caracappa ${ }^{1}$

${ }^{1}$ Rutgers University, Haskin Shellfish Research Laboratory, 6959 Miller Avenue Port Norris, NJ, 08349, USA

${ }^{2}$ NMFS Northeast Fisheries Science Center 166 Water Street, Woods Hole, MA, 02543, USA

The offshore whelk (Buccinum undatum) is a subtidal gastropod caught commercially in baited traps, primarily in Canada and in Europe. A new fishery is developing in the Mid-Atlantic region that is as yet unmanaged, and important biological data about the sustainability of this fishery is not currently available to managers or fishers. Information about waved whelk basic biology including morphometry, sex ratios, length at age, maturation timing etc. were collected in the summer of 2014 in cooperation with the federal scallop survey $(n=138)$. Samples were collected using timed dredge tows (with a liner) from Georges Bank through the continental shelf off South Jersey, at depths ranging from 41 to $132 \mathrm{~m}$. Preliminary results suggest that localized phenotype patterns may exist within the greater metapopulation. This variation could be the result of (1) phenotypic plasticity responding to localized environmental drivers (eg. predators, depth, physical regime, and temperature), or (2) genetic differences that may be suggest limited connectivity among populations. Additional samples are being collected in a fishery cooperative effort in partnership with local fishers that will provide information about fishery selectivity; this work is ongoing. To examine the geographic distribution of whelk, counts were made from images provided from the HabCam federal fishery survey database. The spatial patterns in abundance are patchy and suggest high abundance regions may be associated with areas of Atlantic scallop abundance. These data will be used to help establish a foundation for management strategies to ensure sustainability of the stock and responsible fishery development.

\section{NUTRIENT RECYCLING AT CLAM AQUACULTURE SITES FUELS MACROALGAL PRODUCTION} Anna Murphy, Iris Anderson, Ashley Smyth, Mark Luckenbach

Virginia Institute of Marine Science, P.O. Box 1346, Rt. 1208 Greate Road, Gloucester Point, VA, 23062, USA

As commercial clam aquaculture expands globally, the proposal that bivalve cultivation may be an effective nutrient remediation strategy requires careful consideration. By removing particulates from the water column, delivering organic matter to the sediments, and excreting dissolved nutrients back to the water column, high densities of filter-feeding clams can significantly alter nutrient dynamics in coastal ecosystems. The interactions of extensive clam aquaculture on sediment nitrogen $(\mathrm{N})$ transformations were investigated. Sediment flux measurements confirmed clam beds are regions of high metabolic activity with enhanced nutrient regeneration compared to the control site. Denitrification, the microbial process that removes bioavailable $\mathrm{N}$ from the system, was generally low compared to previous studies involving bivalve sediments. Additionally, ammonium recycling via dissimilatory nitrate reduction to ammonium (DNRA) exceeded denitrification. Denitrification and DNRA at the clam sites averaged $160 \%$ and $450 \%$ higher than the uncultivated sites, respectively. While ammonium fluxes averaged 154 times higher at the clam beds compared to uncultivated sediments, the presence of macroalgae, growing on predator exclusion nets used in Virginia, decreased this nitrogen flux by up to $77 \%$. Through clam excretion and microbial respiration of biodeposits, clam cultivation supplies nitrogen in excess of macroalgal demand, suggesting $\mathrm{N}$ recycling in the benthos alone is sufficient to support macroalgal production. Given the high capacity for macroalgae to temporarily sequester nutrients released from the clam beds, macroalgal harvest may be an effective means remove unwanted nutrients from the ecosystem.

\section{MORPHOLOGY AND AGE DIFFERENTIATION IN THE PACIFIC GEODUCK, PANOPEA GENEROSA, IN CALIFOR- NIA WATERS}

Gabriela Navas

Moss Landing Marine Laboratories, 8272 Moss Landing Road, Moss Landing, CA 95039, USA

The Pacific geoduck, Panopea generosa [Gould 1850, formerly Panopea abrubta Conrad, 1849 (Vadopalas et al. 2010)], ranges from Alaska to Baja California in intertidal to subtidal soft substrates (Anderson 1971, Bernard 1983, Goodwin and Pease 1987). This clam is the largest burrowing bivalve in the world with a siphon length of up to $1 \mathrm{~m}$ ( 3 feet) allowing it to burrow deep into the sediment. Their siphon is highly sought after as a tasty delicacy in international 
markets. Due to an increase in demand, a phase shift from wild fishery to aquaculture of $P$. generosa has been able to keep up with demands (Welch 2012). According to the Washington Department of Fish and Wildlife, this species is generating about \$22 million in revenue for the state every year. In 2008, the Mexican fishery launched its Pacific geoduck market, and is nearing this annual revenue with its wild fishery harvest (Rocha-Olivares et al. 2010). While there is no commercial take of P. generosa in California, a recreational fishery exists despite the lack of knowledge of this bivalve's populations. Results from my thesis research on morphology and age differentiation will be presented at the conference.

A COLLABORATIVE AND ADAPTIVE STRATEGY FOR REBUILDING WHITE ABALONE POPULATIONS IN SOUTHERN CALIFORNIA

Melissa Neuman ${ }^{1}$, David Witting ${ }^{1}$, Susan Wang ${ }^{1}$, Kevin Stierhoff ${ }^{1}$, John Hyde ${ }^{2}$

${ }^{1}$ NOAA/NMFS, 501 W Ocean Blvd., Suite 4200, Long Beach, CA, 90802, USA

${ }^{2}$ NOAA/NMFS Southwest Fisheries Science Center, $8901 \mathrm{La}$ Jolla Shores Drive, La Jolla, CA, 92037, USA

Under the Endangered Species Act (ESA), the National Marine Fisheries Service (NMFS) is charged with developing and implementing recovery plans for endangered species. White abalone (Haliotis sorenseni) was the first marine invertebrate listed as federally endangered under the ESA in 2001 and a recovery plan was completed in 2008. A key part of NMFS' recovery strategy is to test recovery methods on related abalone species before they are implemented with white abalone. NMFS and its partners are directing, coordinating, and/or carrying out conservation activities focused on white abalone and related species in the following areas: 1) captive spawning; 2) captive rearing; 3 ) outplanting methodology; and 4) monitoring wild populations. Despite intermittent issues with health and gonad maturation among broodstock, successful spawning induction has occurred in the laboratory and field for multiple species over the last decade. These efforts have resulted in the production of hundreds of thousands of captive-reared abalone. Outplant method testing of veliger and juvenile stages using surrogate abalone species is underway with innovative instruments for deployment and retention. The effectiveness of remotely operated vehicles (ROVs), SCUBA, tagging (external and genetic), tracking, and recruitment modules to monitor wild abalone populations is being assessed and the identification of metrics most appropriate for measuring the health and viability of abalone populations is being determined. The successful recovery of white abalone will depend on collaborations that capitalize on each partner's expertise and infrastructure and program flexibility that allows for lessons learned in one phase to be applied to subsequent phases.

\author{
MEASURING RISK: UNCOVERING THE ROLE OF WATER \\ TEMPERATURE AND pH ON SEASONAL CHANGES IN \\ MUSSEL ATTACHMENT STRENGTH \\ Laura A. Newcomb ${ }^{1,2}$, Ian Jefferds ${ }^{3}$, Emily Carrington ${ }^{1,2}$ \\ ${ }^{1}$ University of Washington, Department of Biology, Box \\ 351800, Seattle, WA, 98195, USA \\ ${ }^{2}$ Friday Harbor Laboratories, 620 University Road, Friday \\ Harbor, WA, 98250, USA \\ ${ }^{3}$ Penn Cove Shellfish, 106 N. Sherman Road, Coupeville, WA, \\ 98239, USA
}

Mussel survival is directly linked to its strong attachment on the shore. Stretchy tethers called byssal threads enable attachment in habitats with strong currents and waves. Our recent laboratory studies revealed temperature, $\mathrm{pH}$, and reproduction can all weaken mussel attachment strength. Here we applied these results in situ by examining the correlation between these variables and mussel attachment strength at a commercial aquaculture mussel farm. Using mussels grown in suspension culture at Penn Cove Shellfish, we quantified the range of natural conditions mussels experience seasonally and examined how mussel byssus attachment strength responds to changes in environmental variables. We measured whole mussel attachment and reproductive state monthly on aquaculture lines at 1 and $7 \mathrm{~m}$ depth, while temperature and $\mathrm{pH}$ were measured hourly. It was hypothesized that mussel attachment strength should be weaker when temperature is high, $\mathrm{pH}$ is low, and after mussels spawn. Over the course of a year, temperature ranged from 3 to $20^{\circ} \mathrm{C}$ while $\mathrm{pH}$ ranged from 7.2 to 8.4. Overall, mussels living at $7 \mathrm{~m}$ grew in water with lower $\mathrm{pH}$, lower summertime temperature, and higher wintertime temperature. Sixteen months of monitoring show mussels experience a two-fold drop in strength during the summer when temperature is elevated. Differences in attachment strength between the two depths during certain seasons suggest temperature and $\mathrm{pH}$ gradients in the field directly influence mussel attachment strength. If mussel fall-off of culture lines at farms continues to rise, an adaptive management strategy may be to monitor water conditions and adjust growing and harvesting practices accordingly.

\section{OLYMPIA OYSTER POPULATIONS AT THIRTEEN LOCA- TIONS ACROSS BRITISH COLUMBIA}

Tammy Norgard, Graham Gillespie, Sean MacConnachie, Jessica Finney

Pacific Biological Station, Fisheries and Oceans Canada, 3190 Hammond Bay Road, Nanaimo, British Columbia, V9T 6N7, Canada

Olympia oysters, Ostrea lurida (Carpenter 1864), were first assessed by the Committee on the Status of Endangered Wildlife in Canada (COSEWIC) in 2000 and were listed under the Species At Risk Act in 2003 as a species of Special Concern. Fisheries and 
Oceans Canada posted a five-year management plan in response to the listing and the goal of the plan is to maintain stable populations of Olympia oysters in BC. One of the identified management actions was to monitor relative abundance levels at index sites at least once every five years. In 2009 a Science Advisory Report was written recommending the establishment of index sites for Olympia oyster monitoring. Thirteen index sites were chosen to monitor changes in relative abundance spanning the majority of the Olympia oyster range in Canadian waters. This presentation is a summary of the results from surveys at these index sites between 2010 and 2014.

OBSERVATIONS OF GONAD STRUCTURE AND GAMETOGENIC TIMING IN A RECOVERING POPULATION OF OSTREA LURIDA (CARPENTER, 1864)

Mark S. Oates ${ }^{1}$, Craig M. Young ${ }^{2}$

${ }^{1}$ Marine Science Institute, 500 Discovery Parkway, Redwood City, CA, 94063, USA

${ }^{2}$ University of Oregon, 63466 Boat Basin Road, Charleston, OR, 97420, USA

In the Pacific Northwest, Olympia oyster, Ostrea lurida, stocks were dramatically reduced by overharvesting and habitat loss. Restoration efforts of the native oyster require information on the timing of gametogenesis and spawning. From January 2012 to December 2012, adult oysters from two intertidal populations were collected on a monthly basis in the Coos Bay estuary, Oregon for histological analysis of their gonads. Gametogenesis and spawning occur seasonally from May through September, when water temperatures exceed $14.5^{\circ} \mathrm{C}$, with brooding oysters found from July through September. Oocyte diameters increased significantly from May to June and from June to July within oyster populations at Haynes Inlet (Site 1) and Coalbank Slough (Site 2), respectively. Male gametogenesis initiated in May at Site 1 and in June at Site 2. Dry meat condition values increased significantly during periods of reproduction and decreased following the reproductive season's end. Condition index values for Site 2 were consistently lower than those at Site 1, suggesting poor nutrition or physiological stress. Salinities below recorded physiological thresholds are believed to be the primary environmental factor influencing the discrepancy in reproductive activity at Site 2 .

RECRUITMENT, SURVIVAL, AND GROWTH OF THE OLYMPIA OYSTER (OSTREA LURIDA) AND THE JAPANESE OYSTER (CRASSOSTREA GIGAS) AS A FUNCTION OF TIDAL HEIGHT

Thomas Parker, Rick Torres, Jennifer Burnaford, Danielle Zacherl

California State University Fullerton, Department of Biological Science, Fullerton, CA, 92831, USA
Surveys of seawalls in southern California bays have uncovered zonation of native (Ostrea lurida) and non-native (Crassostrea gigas) oysters, where non-natives reach their maximum density higher in the intertidal zone than natives. This zonation may be explained through differences in settlement, recruitment, and/or growth and survival across species. The effects of varying tidal heights on recruitment, survival, and growth of native and nonnative oysters in San Diego Bay, California were explored during summer and fall 2014. To assess recruitment levels, twenty ceramic tiles were placed onto a fence at varying tidal heights and replaced every two weeks for five months. To measure growth and survival, ten ceramic tiles, each with ten recently settled native oysters and two to four non-native oysters, were transplanted to varying tidal heights from $-0.25 \mathrm{~m}$ MLLW to $+1 \mathrm{~m}$ MLLW and checked periodically for 14 weeks. Increased tidal height significantly reduced recruitment of both species, with a more significant decline for native oysters. After 14 weeks, native oysters experienced $100 \%$ mortality at all tidal heights; non-native oysters survived throughout the tidal range. Growth of both native and non-native oysters was not significantly affected by tidal height, but non-natives showed a trend toward faster growth at lower tidal heights. Recruitment patterns alone may explain adult zonation patterns for $O$. lurida, but further studies are required to understand why $C$. gigas is not achieving higher densities at lower tidal heights. Results will help facilitate installation of restoration beds at tidal heights that maximize native performance and minimize non-native performance.

\section{FAUNAL COMMUNITY USE OF ENHANCED AND NATU- RAL OYSTER REEFS IN DELAWARE BAY}

Jenny Paterno, David Bushek, Lisa Calvo

Rutgers University, Haskin Shellfish Research Laboratory, 6959 Miller Avenue, Port Norris, NJ, 08349, USA

A subtidal three-acre plot in the upper Delaware Bay has been planted with oysters and shell by Rutgers University's, Project PORTS (Promoting Oyster Restoration Through Schools), since 2007. Project PORTS is an educational science, technology, engineering and mathematics (STEM) outreach program that engages local school children in building shell bags that serve as cultch for oyster (Crassostrea virginica) larvae settlement. This study compared the diversity of nekton and benthic macroinvertebrates on the enhancement area with nearby unenhanced bottoms containing low or high densities of oysters. Monthly trawl and benthic habitat tray samples were collected from July through November 2013. Individuals $(n=3820)$ representing 47 species were collected and varied seasonally. Multivariate analyses indicated similar fish and macroinvertebrate communities across sites. Cumulative diversity of fish species was greatest at the enhancement site. Average species abundance and richness were, however, highest on sites of high oyster density. Overall, the enhancement area was intermediate to the other habitats in terms of oyster 
abundance and faunal utilization, and thus, it appeared to represent a transitional stage between degraded natural oyster habitat and high oyster density natural habitat. This study was then converted into an educational lesson that utilized field data to provide a 'real-world' connection in the classroom that improved science and math literacy in middle school students. Project PORTS, a small-scale community based restoration program, created oyster habitat supporting a diverse faunal community comparable to that of natural reefs and enhanced STEM learning in $\mathrm{K}-12$ students.

OYSTER REEF RESTORATION IN HARRIS CREEK, MARYLAND: POPULATION SAMPLING AND ESTIMATES

Kennedy Paynter ${ }^{1,2}$, Anne Handschy ${ }^{1}$, Adriane Michaelis ${ }^{1}$, Hillary Lane $^{1,2}$

${ }^{1}$ University of Maryland, Department of Biology, College Park, MD, 20742, USA

${ }^{2}$ Chesapeake Biological Laboratory, University of Maryland Center for Environmental Science, Solomons, MD, 21316, USA

Derelict oyster bars in Harris Creek, a small tributary just inside the mouth of the Choptank River on the north side, are being restored with a combination of bottom assessment, bottom reconstruction, and seed oyster planting. Bottom assessments are conducted using acoustic data and SCUBA diver sampling. Reconstruction is accomplished by a variety of methods to restore a hard bottom that will support seed oyster growth or encourage natural recruitment, or both. Sampling to estimate oyster abundance, mortality and growth is conducted by diver grabs and both random stratified and systematic patent tong sampling. All methods are based on GIS data collected from the reconstruction and planting efforts. In total, over 30 "historic oyster bars" have been targeted for restoration. The hope of such a large focused effort is, in part, to create measureable changes in various parameters of the marine ecosystem in Harris Creek including the oyster population itself, the biogeochemistry of the oyster reefs, the associated reef macrofauna, larger inhabitants such as blue crabs and striped bass, and possibly in aspects of water quality. This report summarizes what we have estimated for the for the oyster populations on restored reefs in Harris Creek.

\section{WASHINGTON SHELLFISH INITIATIVE SPAWNS OLYM- PIA OYSTER HATCHERY}

\section{Betsy Peabody}

Puget Sound Restoration Fund, 382 Wyatt Way NE, Bainbridge Island, WA, 98110, USA

The Washington Shellfish Initiative was launched in 2011 for the express purpose of enhancing shellfish resources in the coastal waters of Washington State. A notable outgrowth of the Initiative is the Kenneth $\mathrm{K}$. Chew Center of Shellfish Research and Restoration, a new, state-of-the-art shellfish restoration hatchery dedicated to producing Olympia oysters and other living marine resources. Officially opening in May 2014, the new hatchery reflects a convergence of interests between NOAA, Washington State and Puget Sound Restoration Fund. In practice, the new hatchery increases the scale of Olympia oyster restoration, creates a hub for associated research and genetics; and builds a base of operations for investigating and mitigating ocean acidification. In Washington State, native shellfish restoration and hatchery propagation have taken on greater significance in recent years for three reasons. One, there is growing recognition that shellfish play a role in maintaining healthy ecosystems. Two, recovering native shellfish species in areas that have lost breeding populations requires some degree of hatchery propagation. And three, the number of species requiring hatchery propagation may increase as a result of ocean acidification. With the new hatchery online, Puget Sound Restoration Fund can produce seed to kick-start Olympia oyster populations in areas that have lost remnant populations and therefore expand geographically. Moving forward, the Washington Shellfish Initiative has created a platform that enables industry, government, research institutions, and nonprofits to pool resources in order to give shellfish and other calcifiers a helping hand as conditions change.

\section{ASSESSING RISK ASSOCIATED WITH THE HARMFUL ALGAL BLOOM SPECIES ALEXANDRIUM MONILATUM TO THE VIRGINIA OYSTER INDUSTRY}

Sarah Pease, Wolfgang Vogelbein, Kimberly Reece

Virginia Institute of Marine Science, The College of William and Mary, P.O. Box 1346, Gloucester Point, VA, 23062, USA

Since 2007, the harmful algal bloom (HAB) species Alexandrium monilatum has bloomed almost annually in southern Chesapeake Bay. This dinoflagellate, A. monilatum, produces "goniodomin A" toxin and is suspected in local mass mortalities of oyster larvae (Crassostrea virginica) grown for aquaculture and restoration projects. Preliminary laboratory exposures of larval and adult oysters to $A$. monilatum resulted in significant morbidity and mortality. Oyster aquaculture in Virginia is a multimillion dollar industry; its representatives recently expressed great concern about HAB impacts on their business. To more effectively manage $\mathrm{HAB}$ risks to the industry, a better understanding of bloom dynamics, spatial and temporal distribution, and impacts on oyster health are required. An important aspect of bloom distribution is the assessment of $A$. monilatum cysts (i.e. the resting cell stage) in bottom sediments. Sediment samples were collected in the southwest portion of Chesapeake Bay in a systematic grid-sampling design. Cyst densities were determined using qPCR and were high 
where blooms had been recorded in previous years, although cysts were present in low densities at most sites. HAB toxicity bioassay methods developed at the Virginia Institute of Marine Science were modified to investigate adverse health impacts of five different cell density treatments of $A$. monilatum on sub-adult oysters $(\sim 40-70 \mathrm{~mm})$. Oysters delayed grazing when exposed to high densities $(>1000$ cells $/ \mathrm{mL}$ ) of $A$. monilatum. Results from these studies could aid in prediction of $A$. monilatum bloom location, severity and health effects on oysters, enabling development of effective management strategies to minimize impacts of $\mathrm{HAB}$ on the Virginia oyster industry.

\section{EXTRACTIVE CULTURES AS A TOOL FOR MITIGATION OF EXCESS NUTRIENT RUN-OFF FROM LAND}

Jens Kjerulf Petersen, Camille Saurel, Paula Canal Vergés

Danish Shellfish Centre, DTU Aqua, Øroddevej 80, DK-7900

Nykøbing Mors, Denmark

In Danish coastal waters, the main anthropogenic impact is excess nutrient run-off from land. On-land measures are already in place but further reduction is required. It is, however, also possible to reach the environmental goals set by the EU Water Framework Directive by removing nutrients from the recipient coastal waters using extractive cultures. Here we report results from trials in the Limfjorden, Denmark where mussels and seaweed farming for mitigation was tested on a realistic scale. The aim was to maximize biomass and area efficiency at as low costs as possible. Commercial long-line units were used for full production cycles. Mussel farming resulted in a production of 900-1100 t blue mussels (Mytilus edulis) in one year corresponding to a nutrient removal of $11-16 \mathrm{t}$ $\mathrm{N}$ and $0.5-0.7 \mathrm{t} \mathrm{P}$. The major costs associate to the production was labour costs. In addition to the direct removal of nutrients, the mitigation culture contributed to increased clarity of the water column, thus contributing to achieve set goals. Based on the collected data, efficiency of using mussels as a mitigation tool for excess run-off of nutrients is assessed and compared with other means of reducing or mitigating excess fertilization of coastal waters. On a smaller scale, efficiency of nutrient removal using kelp (Laminaria saccharina) was tested in a nearby location. Area efficiency was much smaller for growing seaweed, which was inhibited by reduced Secchi depth and heavy biofouling. Further costs associated with seaweed farming are too high to be an efficient mitigation tool.

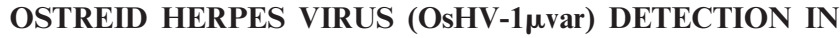
THE IRISH COAST DURING A VERY WARM SUMMER

Maria Prado-Alvarez, Grainne Darmody, Steve Hutton, Amy ÓReilly, Sharon Lynch, Sarah C. Culloty

University College Cork, AFDC, School of Biological, Earth and Environmental Sciences, Ireland
Mortality events in Pacific oysters, Crassostrea gigas, have been related to ostreid herpes virus (OsHV-1) in a number of European countries. A more virulent variant, OsHV-1 $\mu$ var, has been also detected in Australia and New Zealand. Oyster mortality outbreaks have become as one of the most main concerns in the aquaculture sector worldwide. A field survey was carried out during summer 2013 in Ireland, one of the most affected European countries. The current status of a number of cultured oyster populations (12-month-old) was investigated in both areas that have previously been affected by OsHV-1 and never been affected with OsHV-1. Simultaneously, C. gigas spat (three-month-old) from an unaffected population were transferred to the same areas where the field survey was developed. The average of the maximum temperature recorded exceeded by several degrees values in previous years. Mortality levels were regularly registered showing a significant increase associated with higher temperatures in both, $12-$, and three-month old oysters. Mortality rate was higher in three-month-old oysters reaching $90 \%$ mortality at the end of the survey. Prevalence of infection was determined by regular PCR and sequencing of positive amplicons confirmed the presence of OsHV-1 $\mu$ var in Irish waters. Moreover, a positive correlation between prevalence and increase in oyster mortality was found. Among two infected sites, similar mortality levels were observed whereas prevalence of infection was statistically different suggesting that different origins of the spat and the characteristics of the culture areas might have an influence on virus susceptibility.

EXPERIMENTAL INFECTION OF CRASSOSTREA GIGAS SPAT AND LARVAE WITH DIFFERENT SUSCEPTIBILITY TO OsHV-1 $\mu$ var

Maria Prado-Alvarez ${ }^{1}$, Jens Carlsson ${ }^{2}$, Sarah C. Culloty ${ }^{1}$

${ }^{1}$ University College Cork, AFDC, School of Biological, Earth and Environmental Sciences, Ireland

${ }^{2}$ University College Dublin, School of Biology and Environmental Science, Ireland

The ostreid herpes virus OsHV-1 $\mu$ var has been associated to Crassostrea gigas mortalities in countries of both Hemispheres and has acquired global importance in the aquaculture sector. As treatment of bivalves is generally not feasible, genetic selection and selective breeding programs plays an important part in increasing the productivity of aquaculture operations. In this context, breeding for resistance and selection of resistant strains is one long-term option for control of diseases. After a field survey in the Irish coast, spat survivors and broodstock from a site where an especially high mortality event occurred, were collected to be analyzed further. Spat of the same age and broodstock produced in a virus free area were also included in the study. Spat were injected with a suspension of OsHV-1 $\mu$ var and pure breed larvae families were held in water containing the viral suspension. Higher 
mortality was observed in OsHV-1 $\mu$ var exposed spat and larvae compared to controls. OsHV-1 $\mu$ var was also detected in virus exposed animals confirming the efficacy of the infection process in both cases. Percentage of mortality was higher in larvae compared to spat which might show different susceptibility related to the life cycle stage. Mortality levels in virus injected spat from the virus free site were higher than in spat from the infected site, whereas parental origin did not have an effect on larvae mortality levels. Spat and larvae survivors after experimental infection will be further analyzed to identify differently expressed genes that might help identify molecular markers associated to different OsHV$1 \mu$ var susceptibility.

ECOLOGICAL EFFECTS ON THE SCANNING AND TRANSMISSION ELECTRON MICROSCOPE OF THE FOOT AND SHELL IN THE OYSTER PINCTAD $A$ RADIATA (BIVALVIA: PETRIDAE)

Eman Hashem Radwan ${ }^{1}$, Gaber Ahmed Saad ${ }^{2,3}$

${ }^{1}$ Damnhour University, Department of Zoology, Faculty of Science, El Behara, Egypt

${ }^{2}$ Dammam University, Department of Biology, College of Medicine, Saudi Arabia, KSA

${ }^{3}$ Alexandria University, Department of Zoology, Faculty of Science, Alexandria, Egypt

There has been increasing interest in marine oysters (order: Petridae) in recent years because their numbers are declining in many parts of the world and also because they have potential as monitors of pollution. The present study describes the microscopic structure of tissues in the foot as viewed by light and electron microscopy in two locations in Alexandria coast; Egypt; Eastern Harbor (E.H.) and El Asafra. The interventing tissue is dominated by connective tissue containing vesicular cells, muscles, and blood spaces with haemocytes. Based on S.E.M. (Scanning electron microscopy), shell microscopic observations, the projections of the outer surface of the periostracum and inner micro-structures of the shell are described. The outer surface of the periostracum is practically smooth in Pinctada radiata. Under S.E.M., microridges were more evident, but a wide diversity of shapes and patterns of microfringes were observed. Considering the profile of the shell layers, the periostracum is relatively thin and apparently simple. The prismatic layer is thick, consisting of a single series of elongated prisms and wedge-shaped prisms close to the outer surface. The nacreous layer consists of very fine lamellae without pattern or with a slight staircase-like; in this layer is divided by a laminar inclusion of conchiolin. The fringes are abundant and diversified; less resistant to desiccation due to the presence of a wide inter valvar gap. The existence of a greater density of micro-fringes and spikes in Pinctada radiata may be related to the orientation of the animals in order to search for an ideal site for development or for escape from regions subjected to pollution (E.H).

\section{AN ALASKA SEA GRANT, SHELLFISH FARMING INDUS- TRY, AND ALASKA STATE GOVERNMENT PARTNER- SHIP TO GROW A SHELLFISH AQUACULTURE IN ALASKA \\ Raymond RaLonde}

University of Alaska Sea Grant, Marine Advisory Program, 107 W. $3^{\text {rd }}$ Avenue \# 100, Anchorage, AK, 99577, USA

The Alaskan shellfish aquaculture industry has a history of challenging constraints that impeded growth, and during these difficulty times, few farmers survived by 1991. For the subsequent 24 years, the Alaska Sea Grant Marine Advisory Program (MAP) aquaculture mission supported an extension effort to build a biologically sustainable, economically viable, and socially acceptable industry. Through a broad-based program of applied research, regulatory reform, education, extension, and support of many dedicated partnerships, growth of the industry is unprecedented. Social acceptance continues as farmers apply new farming practices that increase production and financial solvency. An Alaska state sponsored loan program, passed in 2013, provides financing for new and existing farmers. A number of MAP initiatives, funded through the NOAA Aquaculture Program, now focus on information delivery, workforce development through the University of Alaska, development of economic models, business management outreach, and recruiting Alaska's youth through high school FFA programs. The recent decline of the timber industry and fishing permits shifting from coastal communities to urban areas has increased interest in developing community based shellfish farming industries. Subsequently, the MAP aquaculture program is being overwhelmed with inquires for outreach and training. Beginning in 2014, three intensive "Introduction to Shellfish Aquaculture in Alaska" workshops were taught in different communities. Website reconstruction is in progress, the "Alaska Oyster Grower's Manual" published, three farming practice manuals are in preparation for publication, FFA chapters identified, additional economics models nearing completion, and an advanced shellfish farming training workshop is being developed for delivery in the spring of 2015.

USING QUALITATIVE MODELS TO EVALUATE ENVIRONMENT-AQUACULTURE LINKAGES IN THE SOUTH PUGET SOUND AND WILLAPA BAY FOOD WEBS

Jonathan Reum ${ }^{1}$, Bridget Ferriss ${ }^{1}$, P. Sean McDonald ${ }^{1}$, Chris Harvey $^{2}$

${ }^{1}$ Washington Sea Grant, University of Washington, Seattle, WA, 98195, USA

${ }^{2}$ NOAA, Northwest Fisheries Science Center, 2725 Montlake Blvd. East, Seattle, WA, 98112, USA

Identifying linkages between aquaculture and environmental variables that relate habitat alteration, climate variability, and watershed development is necessary for anticipating and miti- 
gating against potential future change. In addition, understanding the influence of evolving aquaculture methods on coastal food webs can inform best practices, spatial marine planning efforts, and offer a fuller picture of the ecosystem context aquaculture operates within. A qualitative modeling method that facilitates the integration of diverse data sources into networks that describe key variables and their interactions with aquaculture will be presented. The models consist of qualitative linkages (i.e., positive, negative, and neutral interactions) that may correspond to any type of variable (e.g., trophic, nontrophic, or purely conceptual). The resulting networks offer a summary of our current understanding of key system attributes, can help predict the outcome of system components to qualitative changes in perturbed variables, and help identify linkages that disproportionately influence system responses. The models permit only a limited number of key variables, and therefore demand conceptual clarity and an understanding of the causal connections between the perturbed and ecosystem components of interest. The method using models developed around aquaculture in Willapa Bay and South Puget Sound are demonstrated and system responses to scenarios of future change are compared.

\section{SPAWNING AND OUTPLANTING TECHNIQUE DEVEL- OPMENT FOR GREEN ABALONE (HALIOTIS FULGENS) RESTORATION IN SOUTHERN CALIFORNIA}

David Witting', Tom Ford ${ }^{2}$, Susan Wang ${ }^{1}$, Melissa Neuman², Ariadne Reynolds ${ }^{2}$

${ }^{1}$ National Marine Fisheries Service, West Coast Region, 501 West Ocean Boulevard, Suite 4200, Long Beach, CA, 90802, USA

${ }^{2}$ The Bay Foundation, 1 LMU Drive, Pereira Annex MS: 8160, Los Angeles, CA, 90045, USA

Green abalone (Haliotis fulgens) almost disappeared from Southern California for nearly two decades, largely due to overharvest and disease. Abalone supported commercial and recreational fisheries and play an important role as grazers in kelp forest ecosystems. Project partners are refining techniques for spawning and outplanting green abalone to the coastal Palos Verdes shelf in Southern California. We tested two spawning methods: using captive broodstock, and an approach ("deck spawning") where adult abalone are brought onto the deck of a research vessel, induced to spawn, and returned to their habitat. This approach may replace the need to maintain wild abalone broodstock, which can be costly and ineffective. To date, three deck-spawning attempts have been made. New outplanting equipment and techniques are also in development including a prototype "pump" for injecting green abalone veligers into a holding tent adapted from Heasman et al., 2004. This pump can be sealed before and after veliger deployment to ensure efficient deployment and accurate estimates of veligers deployed, per treatment. A test of the pump in a public kelp aquarium demonstrated a roughly $80 \%$ deployment efficiency and a deployment time of approximately 11 minutes. We plan to outplant abalone veligers and several size classes of juvenile abalone at high and low densities to compare settlement and survival rates. The development and application of methods and techniques used in successful restoration of green abalone will transfer directly to efforts with endangered black and white abalone in southern California and inform international efforts.

INFLUENCE OF DIET AND SEX ON HOST-PATHOGEN RELATIONSHIP: THE CASE OF THE MANILA CLAM (RUDITAPES PHILIPPINARUM) AND ITS PATHOGEN VIBRIO TAPETIS

Gaëlle Richard $^{1}$, Philippe Miner ${ }^{2}$, Nelly Le Goïc ${ }^{1}$, Adeline Bidault ${ }^{1}$, Virgile Quillien ${ }^{2}$, Charlotte Corporeau ${ }^{2}$, Fabrice Pernet ${ }^{2}$, Christophe Lambert ${ }^{1}$, Pierre Boudry ${ }^{2}$, Christine Paillard ${ }^{1}$, Fabienne Guér$\operatorname{ard}^{1}$

${ }^{1}$ UMR 6539 CNRS UBO IRD IFREMER, LEMAR - IUEM - UBO, Institut Universitaire Européen de la Mer, Université de Bretagne Occidentale, Technopôle Brest-Iroise - Rue Dumont d'Urville, 29280 Plouzané, France

${ }^{2}$ UMR 6539 CNRS UBO IRD IFREMER, LEMAR - IUEM - UBO, Ifremer, Laboratoire de Physiologie des Invertébrés, Technopôle Brest-Iroise BP 70 29280, Plouzané, France

Since late 1980s, Manila clams (Ruditapes philippinarum) have been affected by the Brown Ring Disease (BRD) caused by Vibrio tapetis. Although several studies have investigated the effects of environmental parameters such as salinity, temperature, and sediment on this host-pathogen relationship, the effect of food quality have never been investigated. However, diet influences the physiological and immune responses to pathogens in several bivalve species. The main objective of this study was to investigate the effects of two diets on physiological and immune responses of clams to BRD. Also, sex and gonad maturation were evaluated by histology to examine their effects. Specimens were acclimated four weeks with either T-iso or Chaetoceros calcitrans, two algal species which exhibits differences in their biochemical compositions. Then, clams were injected with $V$. tapetis, sterilized seawater or not injected, and further monitored for 30 days. Clam tissues were collected at 1, 3, 7, 14 and 30 days post-treatment to assess immune response by evaluating conchyolin deposit stages and shell repair stages. These two parameters were markedly higher in clams injected with $V$. tapetis compared to other treatments. Preliminary results suggest that sex and maturity influence BRD dynamics whereas the effect of diet would be of minor significance. 
PILOT STUDY OF FAMILY-BASED BREEDING OF TETRAPLOID CRASSOSTREA VIRGINICA

Kate Ritter, Standish Allen

Virginia Institute of Marine Science, 1375 Greate Road, Gloucester Point, VA, 23062, USA

The family-based selection program at the Aquaculture Genetics and Breeding Technology Center has produced several generations of diploid Crassostrea virginica families, the results of which are funneled into a broodstock program for industry. Most commercial seed in the Chesapeake are triploid, resulting from a diploid by tetraploid cross. Little has been done up to this point for family breeding of tetraploids. In the summer of 2010, five tetraploid families were spawned from each of four different lines, resulting in a pilot study of twenty tetraploid families. Of those, eleven survived through deployment and to the end of the one year study period. Throughout the trial, the tetraploid families were monitored regularly for survival, growth rates and sex ratio, as well as reversion prevalence and reversion intensity. Reversion was of key interest: as tetraploids age, their cells tend to shed chromosomes, resulting in a mosaic, with a percentage of its cells triploid and in some cases, diploid. Compounding multigenerational effects of reversion are unknown, though triploid spawns do not seem adversely affected by mosaic parents. Results showed significant differences in prevalence of reversion among the four groups of families, indicating that improvements may be possible via family breeding. Prevalence increased from $39 \%$ to $70 \%$ within the study period, across all families, while reversion intensity increased from $34 \%$ to $38 \%$. The percentage of males increased from $49 \%$ in 2011 to $62 \%$ in 2012 . While there was little variation in growth patterns among families, the cumulative survival ranged from $48 \%$ to $75 \%$.

GAZING INTO THE CRYSTAL BALL FOR AQUACULTURE DEVELOPMENT: WHAT IS IN THE GLOBAL FUTURE FOR INTEGRATED MULTI-TROPHIC AQUACULTURE (IMTA)? Shawn Robinson', Keng Pee Ang' ${ }^{2}$, Alejandro Buschmann ${ }^{3}$, Thierry Chopin $^{4}$, Bruce MacDonald ${ }^{4}$, Gregor Reid ${ }^{4}$

${ }^{1}$ Fisheries and Oceans Canada, Biological Station, St. Andrews, NB, E5B 2L9, Canada

${ }^{2}$ Cooke Aquaculture Inc., 255 Metcalf Street, Saint John, NB, E2K IK7, Canada

${ }^{3}$ Universidad de Los Lagos, Camino a Chiquihue Km 6, Casilla 557, Puerto Montt, Chile

${ }^{4}$ University of New Brunswick, CIMTAN, P.O. Box 5050, Saint John, NB, E2L 4L5, Canada

Future projections on the food requirements for human society over the next several decades suggest that there will be an increasing demand for high-quality protein from marine sources; much of that coming from aquaculture production. Currently, there is growing recognition that the efficiency of production from aquaculture systems need to increase for both economic and environmental sustainability. As a result, initiatives to develop ecologically-based aquaculture practices have been accelerating worldwide over the last two decades, often under the label integrated multi-trophic aquaculture (IMTA). Creating these synergistic systems have been shown to be more complex than initially envisioned and often, only a few individual components of the proposed system have been studied in detail and at reduced time and spatial scales. While there have been some trends in nutrient transfer that are common between geographic regions, most studies are finding significant amounts of temporal and spatial variability in measuring and capturing nutrient flows. With the exception of China, most of the work has been done on seaweeds and filter feeders (bivalves). The current mono-culture finfish aquaculture industry has been slow to adopt IMTA principles in a large part because of the perceived risk to their high capital investment in their operation and the lack of answers to many of their practical questions. These include processing, marketing and sales as well as the profitability which must more than offset the "distraction" created by the transfer of resources from their "core" business species. Much of the information gathered to date is biological in nature and progress is needed for areas of engineering, economics, marketing, education and coastal zone management (social license). This information needs to be region-specific given the wide diversity of environments and species cultured. We propose a series of demonstration farms be created in different regions, using the best technology available todate, to investigate the efficiency of an IMTA system using multiple metrics as a means to facilitate the adoption of IMTA principles by the aquaculture sector.

IMPACT OF COREXIT 9500 ON THE EARLY LIFE STAGES OF THE EASTERN OYSTER, CRASSOSTREA VIRGINICA

Rachel Rodriguez ${ }^{1}$, Sean Powers ${ }^{2}$, Andrew Whelton ${ }^{3}$, Julia Edelbrock $^{4}$, Scott Rikard ${ }^{5}$, Anne Boettcher ${ }^{6}$

${ }^{1}$ University of South Alabama, Department of Biology, Mobile, AL USA

${ }^{2}$ University of South Alabama, Department of Marine Sciences, Mobile, AL, USA

${ }^{3}$ Purdue University, Division of Environmental and Ecological Engineering and Lyles School of Civil Engineering, West Lafayette, IN, USA

${ }^{4}$ University of Findlay, Department of Biology, Findlay, OH, USA

${ }^{5}$ Auburn University Shellfish Laboratory, Dauphin Island, AL, USA

${ }^{6}$ Embry-Riddle Aeronautical University, Director of Undergraduate Research and Honors Program, Prescott, AZ, USA

In the aftermath of the 2010 Deepwater Horizon Oil Spill, approximately 1.8 million gallons of dispersant was used in offshore waters in an effort to mitigate the impacts of the 200 
million gallons of oil released. The primary dispersant was Corexit 9500. It is important to establish that while this dispersant was only released in offshore waters; companies are advocating near shore releases of dispersant in the event of future spills. While Corexit 9500 toxicity to the eastern oyster, Crassostrea virginica, has been studied in adults, little is known about the impacts on early life stages. This study tested the toxicity of Corexit-alone, oil-alone, and dispersed oil on the larval and early spat stages of $C$. virginica. Five size classes were tested: 0.1, 0.2, 0.3, 0.7, $2.0 \mathrm{~mm}$. Each size class was exposed to six concentrations of Corexit: 0-50 ppm, 4 concentrations of oil: $0-10 \mathrm{ppm}$ and to the same 4 concentrations of oil with a 1:20 part Corexit. Each test ran for 48 hours. In the Corexit-alone experiments, mortality increased with increasing concentration and decreased with oyster age. For oil-alone, no mortality was observed. For dispersed oil exposures, consistently high mortality was seen at a $5 \mathrm{ppm}$ oil concentration and mixed mortality in the $10 \mathrm{ppm}$ treatment. Results indicate that Corexitalone or in combination with oil is more toxic than oil alone. Sublethal effects of Corexit 9500 are currently being tested by assessing the expression of the stress biomarker, heat shock protein 70 in larvae and spat exposed to Corexit.

\section{WHEN A NEW FISHERY IS CREATED: THE BELIZE SEA CUCUMBER EXPERIENCE}

\section{Arlenie Rogers}

University of Belize, P.O. Box 340, Stann Creek Extension, Belmopan City, Belize, Central America

Sea cucumbers have been fished in Belizean waters for the past 20 years with the original market being in Guatemala and a local market in Belize (Asians living in Belize). Over the years, the markets and prices have increased. Since the fishery was legally opened in 2009, fishers are pleased with an alternative fishery other than lobster, conch and fish. Some fishers rate sea cucumber fishing as their primary fishing activity. Of the nineteen species reported to occur in Belizean waters, two species are commercially exploited but only one is regulated by the Belize Fisheries Department. Although fishers know very little about the sea cucumber biology or ecology, they are concerned about the decrease in catch and the need to travel farther to fish sea cucumbers. The addition of more licensed and unlicensed fishers and new exporters has increased harvest. Sea cucumbers sold locally are not reflected in the market economy or used to adjust the Total Allowable Catch. Catch per unit effort decreased drastically in 2014 when compared to catch for 2010.

SEARCHING FOR A STOCK RECRUITMENT RELATIONSHIP FOR RED ABALONE IN CALIFORNIA

Laura Rogers-Bennett ${ }^{1,2}$, Cynthia Catton ${ }^{2}$, Christy Juhasz ${ }^{2}$, David Kushner $^{3}$

${ }^{1}$ University of California Davis, Bodega Marine Lab, P.O. Box 247, Bodega Bay, CA, 94923, USA
${ }^{2}$ California Department of Fish and Wildlife, Bodega Marine Laboratory, 2099 Westside Road, Bodega Bay, CA, 94923, USA

${ }^{3}$ Channel Islands National Park, 1901 Spinnaker Drive, Ventura, CA, 93001, USA

Red abalone is the only species of abalone open to fishing in California. In northern California, red abalone populations support a free-diving only, recreational fishery with a limited season, size limits and both daily and yearly bag limits. One question which remains for red abalone is whether there is evidence of a relationship between local stock size and recruitment. Populations in northern and southern California with differing stock sizes were examined over 12 years to see if stock size is a good predictor of the numbers of juveniles $(<51 \mathrm{~mm})$ found inside Abalone Recruitment Modules (ARMS). Results showed that an area with more adult broodstock $\left(>0.48\right.$ red abalone per $\left.\mathrm{m}^{2}\right)$ had three times the recruitment compared with an area with less dense $(<0.18 \mathrm{red}$ abalone per $\mathrm{m}^{2}$ ) stocks in the south and that good years for juvenile recruitment in northern California were also good years in the southern California time series. Furthermore, these data clearly indicate that not every year is a good recruitment year for red abalone in California. More work is needed at more sites to determine if there is a relationship between stock size and reproductive output in good years.

\section{QUANTIFYING SURFACE-PROPERTY PROFILES OF MICROALGAE TO DEVELOP PARTICLE-SELECTION MODELS FOR BIVALVES}

Maria Rosa ${ }^{1}$, J. Evan Ward ${ }^{1}$, Bridget A. Holohan ${ }^{1}$, Sandra E. Shumway ${ }^{1}$, Gary H. Wikfors ${ }^{2}$, Emmanuelle Pales Espinosa ${ }^{3}$, Bassem Allam ${ }^{3}$

${ }^{1}$ Department of Marine Sciences, University of Connecticut, 1080 Shennecossett Road, Groton, CT, 06340, USA

${ }^{2}$ NOAA, National Marine Fisheries Service, Northeast Fisheries Science Center, 212 Rogers Avenue, Milford, CT, 06460, USA

${ }^{3}$ School of Marine and Atmospheric Sciences, Stony Brook University, Stony Brook, NY, 11794, USA

The capabilities of bivalves to selectively feed have been well documented, and physicochemical properties of particles have been implicated as possible selection factors. Different chemical substances (e.g., proteins, carbohydrates, humics) likely change the surface characteristics of microalgae, and previous studies suggest a correlation between cell-surface carbohydrates and physicochemical properties. Understanding the differences in surface properties can help determine which differences serve as selective cues for various bivalve species. Surface-property profiles for 16 different microalgal species and three different detrital particles were determined. Surface charge was measured using a Zetasizer Nano ZS@ (Malvern Instruments Inc., UK). Wettability was determined by measuring the contact angle of the live microalgae 
and particles. Data were analyzed using discriminant analysis (DA), and the developed model explained $96 \%$ of the data variability. Discriminant functions (1 being the highest) were 0.496 (angle) and 0.784 (charge), indicating that surface charge was the more important factor in classifying data. Differences and similarities in particle surface properties were then used to design mixed-algal feeding experiments to assess selection by the eastern oyster Crassostrea virginica and the blue mussel Mytilus edulis. Results show preferential rejection of some algal species over others. The quantified surface properties will be used with particle fates (rejected vs. accepted) to model selection statistically.

THE NOAA NATIONAL SHELLFISH INITIATIVE: BUILDING PARTNERSHIPS TO MAXIMIZE THE ECOLOGICAL AND ECONOMIC BENEFITS OF SHELLFISH

Michael C. Rubino ${ }^{1}$, Susan M. Bunsick ${ }^{1}$, Summer Morlock ${ }^{2}$, Robert C. Jones ${ }^{1}$, Kay McGraw ${ }^{2}$

${ }^{1}$ NOAA Fisheries Office of Aquaculture, 1315 East-West Highway, Silver Spring, MD, 20910, USA

${ }^{2}$ Marine Habitat Resource Specialist, NOAA Restoration Center, 1315 East-West Highway, Silver Spring, MD, 20910, USA

NOAA launched the National Shellfish Initiative (NSI) in 2011 with a dual purpose of stimulating coastal economies and improving ecosystem health. The premise for the initiative is simple: shellfish provide a broad suite of economic, social, and environmental benefits, which accrue as a result of both sustainable commercial aquaculture and shellfish conservation. These benefits include: jobs and business opportunities; habitat for important commercial, recreational, and endangered and threatened species; recovery of populations of native shellfish species; more seafood to meet the growing consumer demand in today's market; nutrient removal and cleaner water; shoreline protection. The NSI is jointly managed by the NOAA Restoration Center and the Office of Aquaculture at NOAA Fisheries headquarters, with regional Restoration Center staff and Aquaculture Coordinators providing primary points of contact for potential partners (e.g., state and federal agencies, tribes, industry, restoration groups, and academia). It is implemented by NOAA's existing staff, through federal mandates and grant programs, to further encourage and coordinate both shellfish restoration and environmentally sound commercial shellfish farming. Areas for collaboration include marine planning and permitting; environmental research; restoration and farming techniques; and coordinated and innovative financing. NOAA is an active partner in the Washington State Shellfish Initiative, established in late 2011, and is participating in efforts to create shellfish initiatives in other states (e.g., California, Oregon,
Connecticut, Alaska, Hawaii). We welcome ideas for potential collaborations.

\section{A MULTI-DISCIPLINARY DERIVATION AND ESTIMA- TION OF A SEA SCALLOP (PLACOPECTEN MAGELLANI- CUS) ABUNDANCE INDICATOR \\ David Rudders, John Ward}

Virginia Institute of Marine Science, College of William and Mary, Rt. 1208 Greate Road, Gloucester Point, VA, 23062, USA

Numerous efforts to utilize and rehabilitate catch per unit effort (CPUE) as an abundance estimator rely on its efficacy in representing an unbiased estimate of the true abundance. In some cases, CPUE is used in the absence of other measures of abundance, specifically fishery independent resource surveys. This approach generally relies on the assumption that the fishery independent survey is a true measure of stock abundance even though examples exist where results from these surveys are questionable. However, if two independently derived estimates demonstrate the same trend, then both methods are more likely to be capturing the true trend in fish stock abundance. A novel CPUE estimation method was derived, developed using biological, economic, and fishery management information that results in abundance estimates that are closely correlated with fishery independent surveys of sea scallop stock abundance. In addition to demonstrating the reliability of these estimates, this methodology lends itself to the estimation of stock abundance levels when fishery independent survey data does not exist.

\section{BACTERIAL CHALLENGE OF NORTHERN QUAHOG (= HARD CLAM) MERCENARIA MERCENARIA WITH PUTATIVELY DIFFERENT COGNATE HEAT SHOCK PRO- TEIN LEVELS \\ John Scarpa}

Texas A\&M University - Corpus Christi, Department of Life Sciences, 6300 Ocean Drive (Unit 5800) Corpus Christi, TX, 78412, USA

Previous research examining the use of triploid Mercenaria mercenaria for tolerance to high temperature indicated heat shock protein (Hsp) levels were of significance and not ploidy. It was hypothesized that cognate Hsp (Hsc) provided the protection and that Hsc levels might be heritable. Hsp has also been implicated in disease resistance. Hard clams were surveyed for Hsc (hemolymph, ELISA) and selected for producing three putative low- and high-Hsc lines. Two clams (mean shell length $48.9 \pm 4.0 \mathrm{~mm}$ and whole-weight $36.7 \pm 8.8 \mathrm{~g}, \mathrm{n}=72$ ) from each Hsc-line were placed in six tanks with $12 \mathrm{~L}$ seawater. Three tanks 
for each Hsc-line had live Vibrio parahaemolyticus added (final density $1 \times 10^{6}$ bacteria $/ \mathrm{mL}$ ) on days $1,3,7,10,14$ and 17 . Tanks were monitored daily until day 42 at which time no hard clam mortality had occurred in any treatment. At the end of the experiment the bacterially exposed low- and high-Hsc lines had no change in mean Hsc hemolymph levels as compared to the beginning of the experiment (Low: 0.025 vs. 0.024, High: 0.019 vs. $0.019 \mu \mathrm{g} / \mu \mathrm{L}$, respectively). However, the bacterially exposed low-Hsc clams did have an elevated mean Hsc value as compared to their respective controls $(0.019 \mu \mathrm{g} / \mu \mathrm{L})$, whereas the high-Hsc line was less compared to its control $(0.021 \mu \mathrm{g} / \mu \mathrm{L})$. The hypothesis of Hsc being heritable or that Hsc is indicative of bacterial resistance is not supported by the data. Support for this project was provided by USDA (\#58-3148-0-168) through U.S. - Egypt Joint Board on Scientific and Technological Cooperation (\#1971).

OPTIMIZING MICROALGAL CULTURE FOR A LANDBASED RECIRCULATING INTEGRATED MULTI-TROPHIC AQUACULTURE SYSTEM

John Scarpa ${ }^{1}$, Paul S. Wills ${ }^{2}$, Christopher Robinson ${ }^{2}$, Madelyn E. Russell $^{2}$

${ }^{1}$ Texas A\&M University at Corpus Christi, Department of Life Sciences, 6300 Ocean Drive (Unit 5800) Corpus Christi, TX, 78412, USA

${ }^{2}$ Florida Atlantic University, Harbor Branch Oceanographic Institute, Aquaculture and Stock Enhancement Program, 5600 U.S. Hwy 1 North, Fort Pierce, FL, 34946, USA

Harbor Branch Oceanographic Institute at Florida Atlantic University has for the past three years been operating a prototype Land-Based Integrated Multi-Trophic Aquaculture (LB-IMTA) system, which uses a recirculating water system design. Species utilized in each component of the LB-IMTA system included Florida pompano, shrimp, sea urchins, oysters, and macroalgae. In theory the oysters were to remove and grow on the fine $(<40 \mu \mathrm{m})$ particulates produced in the LB-IMTA system. It was found that the fine particulates did not support oyster growth, but oysters supplemented with microalgae did grow. Therefore, methods for culturing microalgae with LBIMTA water need to be examined. Preliminary experiments indicated that the LB-IMTA water would support the growth of Isochrysis, but cell densities were lower than the traditional batch method. A more thorough examination of different culture variables was performed. Three species of microalgae (Isochrysis, Dunelliela, Cheatoceros) were each examined in a two (water type: LB-IMTA and well saltwater) by five (nutrient type: none added, $\mathrm{f} / 2$, trace metals only, vitamins only, $\mathrm{N}+\mathrm{P}$ only) completely randomized design experiment $(\mathrm{n}=5 \mathrm{rep} / \mathrm{trt})$ in which the microalgae were grown in beakers (4L). Results from each experiment will be presented. This research was supported by the HBOI-FAU Aquaculture Specialty License Plate program.

\section{DILUTION OF THE OYSTER PARASITE PERKINSUS MARINUS BY COMMENSAL TUNICATES} William Schroer ${ }^{1,2}$, Tal Ben-Horin ${ }^{2}$, Gorka Bidegain ${ }^{3}$, Lauren Huey $^{2}$, Joseph P. Looney ${ }^{2}$, Eric N. Powell ${ }^{3}$, Daphne Munroe ${ }^{2}$, David Bushek ${ }^{2}$

${ }^{1}$ Allegheny College, 520 North Main Street, Meadville, PA, 16335, USA

${ }^{2}$ Haskin Shellfish Research Laboratory, Department of Marine and Coastal Sciences, Rutgers University, 6959 Miller Avenue, Port Norris, NJ, 08349, USA

${ }^{3}$ Gulf Coast Research Laboratory, University of Southern Mississippi, 703 E Beach Drive, Ocean Springs, MS, 39564, USA

Competitive interactions among and between species can drive the emergence and persistence of disease. Hosts often encounter pathogens while feeding, but interactions between hosts for food resources and pathogen particles have only recently been integrated into studies of disease transmission. Oyster reefs, their commensal filter-feeding fouling communities, and Dermo disease illustrate this central connection between foraging and transmission. In a series of mesocosm experiments we varied the density of oysters, the dose of the agent of Dermo disease (Perkinsus marinus), and the presence of the commensal, filter-feeding tunicate Molgula manhattensis. It was hypothesized that Dermo transmission could be based on broadly applicable components of resource competition and feeding biology. We found that the presence of tunicates, which were incompetent hosts for Perkinsus marinus, diluted pathogen density in seawater through the consumption of suspended particles, resulting in lower prevalence and intensity of Dermo disease in oysters. These results were integrated in a compartmental disease dynamic model including oysters and $M$. manhattensis as focal and nonfocal hosts for $P$. marinus. The solution to the basic reproduction number $R_{0}$ from the steady state of the model system demonstrated that increasing the density and filtration rate of nonfocal hosts limited disease risk in the focal host population. Ecological interactions between oysters, nonhost filter-feeding communities, and suspended pathogens in the water column are critical to understanding patterns of disease in oysters.

INTEGRATED MULTI-TROPHIC MARICULTURE SYSTEMS: AN ECOLOGICAL APPROACH FOR A SUSTAINABLE AQUACULTURE, BENEFITS, AND CONSTRAINTS Muki Shpigel

Israel Oceanographic and Limnological Research, National Center for Mariculture, P.O. Box 1212, Eilat 88112, Israel

Scarcity of fresh water, overfishing and decline of biodiversity in the oceans, marine eutrophication by anthropogenic activities 
and the increasing demand for sea food, have all reached the point of requiring attention in a more comprehensive, global perspective. Moving from conventional fisheries and aquaculture toward an ecological approach to the development and management of a sustainable aquaculture that cares for environmental, economic and sociological aspects can bring relief to at least some of these issues. Intensive monoculture, however technologically advanced, is hardly sustainable, as it requires vast resources in terms of feeds, fertilizers, chemicals and energy. In addition, it discharges faecal material, uneaten feed, and excretions into the environment. Most of intensive monoculture whether in sea cages or recirculated aquaculture system (RAS) is generally applied to a few luxury species in the upper food web, and does not supply large amounts of inexpensive food. Furthermore, in some places it causes eutrophication, with deleterious effects on marine life, its biodiversity and natural habitats. The economic success of intensive monoculture has much to do with the fact that the growers have rarely been held financially responsible for the environmental pollution their farms cause. Nutrient assimilation in sea cages or land based aquaculture using Integrated Multi-Trophic Systems (IMTA) is a promising ecological approach for a sustainable aquaculture. The rationale behind the IMTA systems is to convert the excretions of the organism cultured upstream into valuable food for the organism downstream, usually with the aid of solar energy. Marine algae and halophyte plants have a high capacity for nutrient uptake per unit of culture area, and can be an important additional healthy and inexpensive produce. IMTA systems in both offshore cages and land based facilities will increase profit for the farmer, improve food conversion rate (FCR), diversify the mariculture products, often create additional jobs, and, most importantly, reduce environmental pollution. The desired trend for IMTA should be: a) Promoting multi-functional uses of the coastal zone (e.g., windmill, aquaculture, tourism, agriculture etc.). b) Moving from intensive monoculture systems towards IMTA systems, using extractive organisms which are at the bottom of the food web, such as algae (macro and micro), bivalves, detrivorous and algivorous fish, c) Using alternative energies (solar or wind) whenever possible to operate the systems d) Shifting from freshwater aquaculture to mariculture.

\section{PERFORMANCE OF THE EUROPEAN SEA URCHIN PAR- ACENTROTUS LIVIDUS REARED ON BIOFILTER-SEA- WEED}

Muki Shpigel, David Ben-Ezra, Vladimir Odnietzov, Lilach Shauli

National Center for Mariculture, Israel Oceanographic and Limnological Research, P.O.B. 1212, Eilat 88112, Israel

The sea urchin Paracentrotus lividus was introduced as a candidate species for commercial development in a fish, seaweed and sea urchin Integrated Multi-Trophic (IMTA) system in Eilat (Red Sea), Israel. While the fish represented the main product, effluents from fish culture supported the growth of the macroalgae
Ulva lactuca and Gracilaria conferta. Both seaweeds were used as a biofilter to remove dissolved nutrients from the water and as forage for the sea urchins. Sea urchin performances in terms of survival, growth, food conversion ratio (FCR), protein and energy use, gonad development and color were evaluated. Growth from spawning to commercial size $(45 \mathrm{~mm})$ on the seaweed diet took approximately 36 months, FCR on a wet weight basis ranged between 5-7, and survival rates from settlement were $70-80 \%$. Three months before harvest, prepared diets were administered to accelerate growth.

EFFECTS OF TEMPERATURE ON FEED INTAKE, GROWTH, OXYGEN CONSUMPTION, AND TEMPERATURE PREFERENCE IN RED KING CRAB

\section{Sten Siikavuopio, Philip James}

Nofima, Muninbakken 9-13, Breivika, PO Box 6122, Langnes, Tromso N-9291, Norway

The current study investigates the effects of temperature on male red king crab (Paralithodes camtschaticus) (average $=2.2 \mathrm{~kg}$ ) at different temperatures $\left(4,8\right.$ and $\left.12{ }^{\circ} \mathrm{C}\right)$. A 110 days trial was undertaken with groups of male king crabs held in 12 land-based holding tanks (4 replicates per temperature treatment). There was $100 \%$ survival throughout the experimental period in the lowest temperature treatment $\left(4^{\circ} \mathrm{C}\right)$. One animal died in the medium temperature group $\left(8^{\circ} \mathrm{C}\right)$ and four animals in the highest temperature treatment $\left(12^{\circ} \mathrm{C}\right)$. Feed intake increased with increasing temperature from an average of $1.0 \mathrm{~g} \mathrm{~kg}^{-1}(\mathrm{dw}) \mathrm{day}^{-1}$ at $4{ }^{\circ} \mathrm{C}$ to $2.8 \mathrm{~g} \mathrm{~kg}^{-1}$ day $^{-1} \mathrm{crab}$ at $12{ }^{\circ} \mathrm{C}$. The percentage meat content in the leg was significantly higher at the final census compared with the initial census in all temperature groups but there were no significant differences in the percentage meat content of the king crabs held in the different temperature treatments at the conclusion of the experiment. Oxygen consumption was also significantly affected by temperature and increased with increasing temperature. The results of the experiment show that the optimal temperature to maintain, and enhance, the meat content of king crab is close to $4{ }^{\circ} \mathrm{C}$. At this temperature the metabolism and feed intake of the king crabs remains relatively low and yet the percentage meat content is the same as crabs held at $12^{\circ} \mathrm{C}$ which consume significantly more feed and have higher mortality.

LONG-TERM GROWTH STUDY OF MALE AND FEMALE GREEN SEA URCHIN, STRONGYLOCENTROTUS DROEBACHIENSIS, UNDER CONSTANT LIGHT AND TEMPERATURE REGIME

Sten Siikavuopio, Philp James, Bjør Steinar Sæther

Nofima, Muninbakken 9-13, Breivika, PO Box 6122, Langnes, Tromso N-9291, Norway

Juvenile green sea urchin, Strongylocentrotus droebachiensis, with an initial mean test diameter of $9.5 \mathrm{~mm}( \pm 1.2 \mathrm{~S} . \mathrm{D})$ were held in 
the laboratory, in individual compartments and at constant temperatures $\left(8.5^{\circ} \mathrm{C}\right)(n=90)$ for a period of 99 weeks. The animals were supplied with flow-through sea water, and fed the Nofima sea urchin manufactured feed ad libitum. Growth, survival, feed intake (FI), feed conversion ratio (FCR), and gonad index (GI) of the sea urchins were monitored during this period. The mortality was $11 \%$ throughout the experimental period. The test diameter (TD) increased significantly with time, best described by a polynomial equation $\left(\mathrm{TD}=0.8756+0.584\right.$ Time $-0.002 \mathrm{Time}^{2}$, $\left.\mathrm{R}^{2}=0.995\right)$. The study showed there were no significant differences in body wet weight or Feed conversion ratio between males and females. However at the end of the experiment the female urchins had a significantly higher GI of $31.1 \%( \pm 4.4)$, compared with the male urchins which had an average GI of $26.8 \%( \pm 5.4)$.

\section{POPULATION GENOMICS AND PHYLOGEOGRAPHY OF OSTREA LURIDA}

Katherine Silliman', Danielle Zacherl' ${ }^{2}$, Ryan Walter ${ }^{3}$

${ }^{1}$ Univeristy of Chicago, Culver Hall 402, 1025 E 57 ${ }^{\text {th }}$ Street, Chicago, IL, 60637, USA

${ }^{2}$ California State University Fullerton, Biological Science, Box 6850, Fullerton, CA, 92834, USA

${ }^{3}$ California State University Fullerton, 800 N State College Blvd., Fullerton, CA, 92831, USA

Understanding the evolutionary processes that cause populations to diverge genetically and phenotypically is crucial to predicting how species will respond to rapid global environmental change. Historically, population differentiation has been considered unlikely for most marine species due to the lack of distinct geographic barriers and the homogenizing effect of planktonic dispersal. However, the past few decades have seen a rapid growth in empirical evidence for local adaptation and population differentiation in some marine species. The Olympia oyster (Ostrea lurida) is patchily distributed from California to the central coast of Canada, extending over strong environmental clines and mosaics that are typically considered necessary for local adaptation to occur. A 2009 taxonomic study on Ostrea spp. using two mitochondrial genes found little to no differentiation among populations, except for a break between Washington and British Columbia. A subsequent $\mathrm{PhD}$ dissertation analyzed 25 populations using 8 microsatellite loci and found genetic structure on broad regional and subregional scales, indicating gene flow may be limited. For this study, we sampled 19 populations of $O$. lurida from San Diego, CA to Quatsino Sound, Vancouver Island. Using tens of thousands of loci obtained from high throughput sequencing, we characterized the underlying demographic model of population structure and identified loci with potential signatures of selection due to local environmental differences. Results from this study will help elucidate the level of connectivity among $O$. lurida populations as well as provide hypotheses of adaptive markers to be experimentally tested in future studies.

\section{CHARACTERIZING KEY PROTEINS THAT CONTRIBUTE TO BARNACLE ADHESION}

Julian Sison ${ }^{1}$, Beatriz Orihuela $^{2}$, Daniel Rittschof ${ }^{2}$, Gary $\mathbf{H}$. Dickinson $^{1}$

${ }^{1}$ The College of New Jersey, Department of Biology, 2000 Pennington Road, Ewing, NJ, 08628, USA

${ }^{2}$ Duke University, Marine Laboratory, 135 Duke Marine Lab Road, Beaufort, NC, 28516, USA

Barnacles can tenaciously adhere to almost any surface. To stick to a surface, glues are released and form an adhesive bond between the surface and the barnacle's base plate. The predominantly proteinaceous glue is composed of approximately a dozen proteins, which serve various roles in the adhesion process. Here, protein characterization was paired with whole organism measures of adhesive strength. Barnacle adhesive strength was quantified in shear using a digital force gauge. The goal was to identify key proteins that contribute to the adhesive strength. Uncured glue from each barnacle was extracted and separated using SDS-PAGE. Abundance of each individual protein was quantified using image analysis software. Correlation analysis revealed a significant positive relationship between the abundance of a $28-\mathrm{kDa}$ glue protein and adhesive strength, i.e. barnacles that expressed more of this particular protein adhered more strongly. This relationship suggests that the $28-\mathrm{kDa}$ protein plays a vital role in adhesion. Subsequent analyses showed that this protein is phosphorylated with a pI of approximately 6.3. Phosphorylated proteins, which possess sticky characteristics due to negatively-charged phosphate groups, may play a role in adhesive functionality of the glue. Understanding what components and characteristics contribute to the glue's effectiveness underwater has many practical implications, including antifouling and biomedical adhesives. The authors gratefully acknowledge funding by ONR, N00014-14-1-0491.

\section{ZOMBIE KING CRABS: THE EFFECTS OF TEMPERATURE AND SALINITY ON LARVAL DEVELOPMENT OF A PAR- ASITIC CASTRATOR \\ Leah Sloan ${ }^{1}$, Sarah Hardy ${ }^{2}$ \\ ${ }^{1}$ University of Alaska Fairbanks; School of Fisheries and Ocean Sciences; Seward Marine Center; PO Box 730; Seward, AK, 99664, USA \\ ${ }^{2}$ University of Alaska Fairbanks; School of Fisheries and Ocean Sciences; P.O. Box 757220; Fairbanks, AK, 99775, USA \\ The parasitic barnacle Briarosaccus callosus infects many com- mercially-harvested king crab species worldwide, including all}


Alaskan king crabs. After infection, the parasite does not kill its crab host, but reduces it to a body that is controlled by the parasite, in other words a "zombie crab." Infected crabs cannot reproduce; instead they raise and care for the parasite eggs and larvae. Salinity and temperature are important factors that likely influence the survival of B. callosus larvae; in Alaskan waters these environmental factors are rapidly changing, which could influence the prevalence of B. callosus in commercially important king crab populations. We examined the effects of temperature and salinity on B. callosus larval survival by raising larvae at a range of temperatures $\left(0-16^{\circ} \mathrm{C}\right)$ and salinities $(19-40)$. Larval survival was highest at temperatures between 4 and $8{ }^{\circ} \mathrm{C}$ and at salinities between 28 and 34; survival declined rapidly outside these temperature and salinity ranges. Future changes in B. callosus larval survival and prevalence in king crab populations will vary by region, depth, and season. In isolated bays and fjords, where salinities may dramatically decrease due to increased freshwater runoff, B. callosus larval survival will likely decrease due to low salinities. However, in open water areas temperature will be the driving factor influencing larval survival, but the direction of change will vary by region, larval behavior, and depth distribution.

\section{EXAMINING WATER QUALITY BENEFITS OF OYSTER} AQUACULTURE

Ashley R. Smyth ${ }^{1}$, Annie E. Murphy ${ }^{1}$, Karen Hudson ${ }^{2}$, Bongkeun Song ${ }^{1}$, Iris C. Anderson ${ }^{1}$

${ }^{1}$ Virginia Institute of Marine Science, College of William and Mary, P.O. Box 1346 Gloucester Point, VA, 23062, USA

${ }^{2}$ Virginia Institute of Marine Science, Marine Advisory Program, VA Sea Grant Program, P.O. Box 1346 Gloucester Point, VA, 23062, USA

Increased nutrient loading along with a sharp decline in bivalve abundance have negatively impacted estuarine ecosystem services. Restoration is often recommended as a way to recover lost ecosystem services and optimize fisheries yield. However, shellfish aquaculture can be an alternative to restoration, providing the same ecosystem services with additional economic benefits. Few studies have examined the effect of aquaculture on nitrogen removal; this lack of data makes it challenging for stakeholder and managers to determine if a growing oyster aquaculture industry improves water quality. We conducted sediment samplings at three commercial scale oyster (Crassostrea virginica) aquaculture farms located throughout the Chesapeake Bay watershed. Nutrient fluxes and denitrification, the conversion of bioavailable nitrogen to $\mathrm{N}_{2}$ gas, were measured from sediments underlying oyster aquaculture cages and compared to control sediments without aquaculture influence. Oyster aquaculture enhanced nitrogen removal via denitrification by $125 \%$ to $450 \%$ over the controls. Denitrification rates measured in aquaculture sediments were similar across sites. While enhanced denitrification is often considered a benefit of oyster reef restoration, our results show oyster aquaculture has similar effects. Understanding the interactions between aquaculture and the environment will help preserve ecosystem services of coastal ecosystems.

\section{PROBIOTICS FOR SHELLFISH HATCHERIES: FROM MECHANISMS OF ACTION TO HATCHERY TRIALS}

Saebom Sohn', Wenjing Zhao', David Nelson ${ }^{3}$, David Rowley ${ }^{4}$, Roxanna Smolowitz ${ }^{5}$, Marta Gómez-Chiarri ${ }^{1}$

${ }^{1}$ University of Rhode Island, Department of Fisheries, Animal and Veterinary Science, 120 Flagg Road, Kingston, RI, 02881, USA

${ }^{2}$ Harvard Medical School, Microbiology and Immunobiology, 77 Avenue Louis Pasteur, Boston, MA, 02115, USA

${ }^{3}$ University of Rhode Island, Department of Biomedical and Pharmaceutical Sciences, 7 Greenhouse Road, Kingston, RI, 02881, USA

${ }^{4}$ University of Rhode Island, Department of Cell and Molecular Biology, 120 Flagg Road, Kingston, RI, 02881, USA

${ }^{5}$ Roger Williams University, Department of Marine Biology, 1 Old Ferry Road, Bristol, RI 02809, USA

The use of beneficial bacteria (probiotics) is an alternative strategy to antimicrobial compounds for disease prevention and control in aquaculture. Two candidate probiotics, Phaeobacter gallaeciensis S4 and Bacillus pumillus RI06-95 showing protection of oyster larvae against bacterial challenge, were previously isolated and characterized in our laboratories. The potential probiotic mechanism by these candidate probiotic strains were investigated and the effects on the growth and survival of larvae of eastern oysters (Crassostrea virginica), hard clams (Mercenaria mercenaria), and bay scallops (Argopecten irradians), in hatchery trials. Pilot-scale trials were also conducted to test the safety and efficacy of developed formulations of two candidate probiotics on oyster larvae for delivery in hatcheries as disease management tools. Probiotic activity by S4 involves contributions from both biofilm formation and the production of the antibiotic TDA (tropodithietic acid). Laboratory trials showed that pretreatment with probiotics protects hard clam larvae, but not bay scallop larvae, against challenge with Vibrio tubiashii. In the hatchery, exposure to probiotics did not affect in the growth or survival of the three molluscan species tested. Exposure of larvae to probiotics S4 and RI06-95 in the hatchery significantly improved larval survival to bacterial challenge with $V$. tubiashii when larvae were collected on day 12 after adding the probiotics to the tank daily. A lyophilized formulation of RI06-95 has been developed that shows ability similar to that of fresh cultures to protect shellfish larvae from bacterial challenge. This research will provide critical information to develop and optimize candidate probiotics for use in shellfish hatcheries. 
TOWARDS THE PAPERLESS OYSTER SURVEY: CONSIDERATION OF DIGITAL DATA ENTRY IN THE FIELD Melissa Southworth, John Thomas, Roger Mann

Virginia Institute of Marine Science, College of William and Mary, P.O. Box 1346, 1375 Greate Road, Gloucester Point, VA, 23062, USA

Modern finfish surveys employ digital fish measuring boards with direct data streaming to databases on weatherized computers. The NEFSC offshore surfclam and ocean quahog surveys do the same. Yet oyster surveys remain in the age of waterproof paper, clipboards, pencils and days of dull and time consuming data entry post survey. Oysters are messy and entirely unsuitable for measuring boards or even digital calipers that fail in mud and salt water. While we will not easily replace the 6 inch plastic ruler, we describe recent exploration of field capable digital recording options to eliminate the clipboard and allow (a) storage of data to space delimited data streams suitable for input to custom databases, and (b) real time data display for QA/QC checking. Options for processing large data sets (the Virginia stock assessment survey measures approximately 100,000 oysters annually) for report and/or web display are considered in terms of both time saved and person hours liberated for more productive purposes.

GROWTH OF THE CHANNELED WHELK BUSYCOTYPUS CANALICULATUS IN BUZZARDS BAY, MASSACHUSETTS OVER ONE OR TWO YEARS AT LIBERTY

Brad Stevens, Bhae-Jin Peemoeller

University of Maryland, Eastern Shore, Princess Anne, MD, 21853, USA

With the southern New England lobster fishery in distress, lobster fishermen have focused more effort toward harvesting channeled whelk (Busycotypus canaliculatus). However, minimal research has been conducted on the life history and growth rates of channeled whelk. Melongenid whelks generally grow slowly and mature late in life, a characteristic that can make them vulnerable to overfishing as fishing pressure increases. Channeled whelk were sampled from Buzzards Bay, Massachusetts, in August 2010 and in July 2011, their gonad development by histology was studied, and they were aged by examining their opercula. Over 8700 whelks were marked and released, and 314 were recovered after one or two years at liberty. Males had significantly slower growth and a lower maximum size than females. Male whelk reached $50 \%$ maturity $\left(\mathrm{SM}_{50}\right)$ at $115.5 \mathrm{~mm}$ shell length (SL) and at the age of 6.9 years. Female whelk reached $\mathrm{SM}_{50}$ at $155.3 \mathrm{~mm} \mathrm{SL}$ and at the age of 8.6 years. With a minimum size limit of $69.9 \mathrm{~mm}$ (2.75 in) in shell width, males entered the fishery at 7.5 years, a few months after $\mathrm{SM}_{50}$, but females entered the fishery at 6.3 years, approximately 2 years before $\mathrm{SM}_{50}$. Various modifications to size limits and their potential impacts on landings were examined. Increased fishing pressure combined with slow growth rates and the inability to reproduce before being harvested can easily constrain the longterm viability of the channeled whelk fishery in Massachusetts.

INVESTIGATING REGIONAL DIFFERENCES IN GROWTH AND NATURAL MORTALITY RATES OF THE PACIFIC GEODUCK, PANOPEA GENEROSA, IN WASHINGTON STATE USA FOR MANAGEMENT OF THE COMMERCIAL WILDSTOCK FISHERY

Bethany Stevick, Bob Sizemore

Washington Department of Fish and Wildlife, 1111 Washington Street SE, Olympia, WA, 98501, USA

The commercial fishery for the Pacific geoduck, Panopea generosa, has been active since 1970 in Washington State, USA and it is managed by calculating a total allowable catch (TAC) for each of six harvest regions. A sustainable yield of $2.7 \%$ was developed and agreed upon by co-managers using age-based parameters from geoduck samples collected throughout the entire state. This single harvest rate is applied to the commercially available biomass to calculate each regional TAC. To understand geoduck population dynamics at a finer scale, the Washington Department of Fish and Wildlife and Treaty Tribes are conducting a Puget Sound wide aging project to elucidate any regional differences. Growth and natural mortality will be estimated for each management region using current geoduck age structure from unexploited areas. These parameters will then be used in the geoduck age-based equilibrium yield model to calculate regional harvest rates. A sample from the Strait of Juan de Fuca region was aged and the mean age was $46.1 \mathrm{y} \pm 1.36$ (SE) with a range of 2 to $128 \mathrm{y}(n=578)$. The estimated growth coefficient $(k)$ was 0.282 and the instantaneous natural mortality rate $(M)$ was $0.0222 \mathrm{y}^{-1}$. Another large geoduck sample $(n=808)$ was taken from the South Puget Sound region in 2014 and shells are currently being aged. Adjustments to the harvest rate will be recommended in these regions if growth and mortality rates differ significantly from the current statewide parameters.

\section{A COMPARATIVE STUDY OF HABITAT VALUE FOR THE JUVENILE BLUE CRAB (CALLINECTES SAPIDUS) PRO- VIDED BY OFF-BOTTOM OYSTER FARMING IN THE NORTHERN GULF OF MEXICO}

Eric R. Stewart, William C. Walton

Auburn University, School of Fisheries, Aquaculture and Aquatic Sciences, 150 Agassiz Street, Dauphin Island, AL, 36528, USA

In the northern Gulf of Mexico, the availability of complex nursery habitat is a critical limiting factor for the juvenile blue crab, 
Callinectes sapidus. Beds of submerged aquatic vegetation and oyster reefs are both commonly acknowledged for providing this valuable habitat for juvenile blue crabs. However, the gear used for off-bottom oyster farming, which is the culture of oysters in mesh containers held above the seafloor, could provide additional nursery habitat for juveniles of this species, especially in areas where other suitable habitat types are limited. In order to make a comparative assessment of whether off-bottom oyster farming gear could or could not provide an additional type of valuable nursery habitat for juvenile blue crabs, field sampling and field tethering experiments were performed to collect data on off-bottom oyster farming gear used in the adjustable longline system, bagged oyster shell, submerged aquatic vegetation, and unvegetated bottom habitats during the summer and fall of 2013 at three spatially separated field sites located in the coastal waters of Alabama and Louisiana. Evaluations were based on comparisons of average density, size, and percent survival data. The results show that juvenile blue crab densities, sizes, and survival rates are generally highest in the off-bottom oyster farming gear than in the other habitat types, indicating that the off-bottom oyster farming gear can provide juvenile blue crabs with an additional type of valuable nursery habitat.

\section{PATTERNS IN EPIBENTHIC COMMUNITIES EXPOSED TO VARYING LEVELS OF FISHING PRESSURE ON GEORGES BANK, USA}

Kevin D. E. Stokesbury ${ }^{1}$, N. David Bethoney ${ }^{1}$, Jonathan D. Carey ${ }^{2}$, Bradley P. Harris ${ }^{3}$

${ }^{1}$ University of Massachusetts Dartmouth, School for Marine Science and Technology, 706 South Rodney French Boulevard, New Bedford, Massachusetts, 02744, USA

${ }^{2}$ Washington Department of Fish and Wildlife, 1111 Washington Street SE, Olympia, WA, 98501, USA

${ }^{3}$ Alaska Pacific University, Department of Environmental Science, 4101 University Drive, Anchorage, AK, 99508, USA

The designation of three large closed areas on Georges Bank in 1994 provided a unique opportunity to examine the impacts of commercial scallop (Placopecten magellanicus) harvesting over a range of fishing scenarios. In 1999, portions of these closed areas were re-opened to limited scallop harvesting, and in 2004 they were incorporated into a formal rotational fisheries management plan. We began surveying the scallop grounds of Georges Bank with underwater video in 2003, sampling approximately 3600 quadrats located at 900 stations annually through 2011. This analysis examines areas that have been closed to mobile gear fishing since $1994\left(12561 \mathrm{~km}^{2}\right)$, areas open to intensive, sporadic fishing since $1999\left(5714 \mathrm{~km}^{2}\right)$, and areas continually open to fishing (10248 $\mathrm{km}^{2}$ ). The temporal abundance of scallops, overall frequency and presence of fish and invertebrate groups (representing over 50 species) within each of these areas were assessed with the expecta- tion that abundances and frequencies would be inversely related to fishing intensity. In overall diversity, distribution, and abundance of groups, areas with sporadic fishing and those that were closed to fishing had similar patterns. These findings support the hypothesis that a rotational management system, resulting in episodic mortality events similar to natural mortality in a dynamic environment, is less disruptive to the benthic community than continual fishing pressure and equal to permanently closed areas provided that the time period of the closure reflect the life cycles of the benthic species.

\section{LARGE-SCALE COMMERCIAL TRIPLOID OYSTER (CRASSOSTREA VIRGINICA) AQUACULTURE IN SOUTH CAROLINA, USA: CONCERNS, CHALLENGES, AND OPPORTUNITIES}

Benjamin Stone $^{1}$, Nancy Hadley ${ }^{2}$, Denise Sanger ${ }^{1}$, Amanda Fornal ${ }^{1}$, Dianne Greenfield $^{1}$, Peter Kingsley-Smith ${ }^{1}$

${ }^{1}$ South Carolina Department of Natural Resources (SCDNR), Marine Resources Research Institute, 217 Fort Johnson Road, Charleston, SC, 29422, USA

${ }^{2}$ South Carolina Department of Natural Resources (SCDNR), Office of Fisheries Management, 217 Fort Johnson Road, Charleston, SC, 29422, USA

In 1993, a commercial-scale clam (Mercenaria mercenaria) farm began using circular PVC pens in Charleston and Beaufort counties, South Carolina, USA. This business venture failed in 2006, with insufficient financial mechanisms in place to remove the approximately 9,000 pens that remain to this day. Large-scale, commercial shellfish aquaculture operations were not attempted again in South Carolina until 2013, when a new company was granted an experimental permit to deploy OysterGro ${ }^{\mathrm{TM}}$ cages in Fish Creek, an undeveloped tidal creek in the ACE Basin NERR, for the commercial production of single triploid oysters (Crassostrea virginica). Prior to the establishment of this oyster farm, only small-scale floating bag or off-bottom cage operations had been attempted in South Carolina by individual growers trying to produce single triploid oysters, primarily for high-end, niche restaurant markets. To safeguard against the undesirable ramifications of future gear loss or abandonment, the company operating in Fish Creek has been required to put up a surety bond to cover the costs of recovering their grow-out apparatus should it become abandoned. Furthermore, the SCDNR is implementing a multifaceted monitoring program to investigate changes that this largescale aquaculture operation may have on water quality parameters, natural oyster recruitment and growth, shoreline accretion or erosion, and the benthic communities in the vicinity of the floating cages. The SCDNR is working closely with this company to provide guidance and oversight as needed, and in the hopes of learning lessons that may be applied to future aquaculture ventures in South Carolina. 
STABLE ISOTOPE ANALYSIS OF BLUE CRABS RELATIVE TO WATER QUALITY IN BLACKBIRD CREEK, DELAWARE

Matthew Stone, Gulnihal Ozbay, Venugopal Kalavacharla

Delaware State University, 1200 North DuPont Highway, Dover, DE, 19901, USA

Eutrophication processes can impact the quality of aquatic food product, especially shellfish. Increasing anthropogenic activity along the Delaware coastline contributes to nitrogen and carbon loading into watersheds, resulting in alteration of biogeochemical cycles within abiotic and biotic components. Previous work has shown that a relationship exists between inorganic nutrient uptake by primary producers and subsequent transfer of energy to higher level consumers. Blackbird creek drains 20,000 acres into Delaware Bay. It does not possess many point sources of pollution, but there is a great deal of agriculture $(\sim 44 \%)$ throughout the watershed. Often, it is difficult to assert whether non-point runoff is impacting the basin, so this project attempts to use stable isotope analysis of Blue crabs (Callinectes sapidus) to determine the health of the ecosystem as it pertains to higher trophic level biota, coupled with water quality analysis. Nitrogen and carbon stable isotope ratios provide spatiotemporally-integrated information about inorganic nutrient flow through food webs. These enrichment signatures, particularly when coupled with those of cropland soils, can potentially indicate effects of nutrient loading on upper trophic levels. Crab and water samples were collected MaySeptember 2014 in the lower and middle reaches of the creek. Previous work in North Carolina proved that in anthropogenically-impacted watersheds an inverse relationship between nitrogen isotopic composition and water quality exists. A linear regression of data in Blackbird Creek did not yield this relationship, thus indicating that the watershed is in good biogeochemical standing and that the crabs within are appropriate for harvest and consumption.

ENVIRONMENTAL FACTORS INFLUENCING POPULATION DYNAMICS OF THE BLUE CRAB (CALLINECTES SAPIDUS) IN A LARGE TIDAL CREEK NEAR THE DELAWARE BAY AND POSSIBLE IMPLICATIONS TO STABLE ISOTOPE ANALYSIS

Matthew Stone, Gulnihal Ozbay, Venugopal Kalavacharla

Delaware State University, 1200 North DuPont Highway, Dover, DE, 19901, USA

The identification of environmental parameters, coupled with analysis of stable isotopes, has been shown to be useful in understanding which factors affect the populations of various fish species. These factors include salinity, shoreline habitat, and land use. This project seeks to identify which aspects of the environment impact the stable isotopic signatures of blue crabs (Callinectes sapidus). Crabs were collected May-September 2014 and analyzed for $\delta^{15} \mathrm{~N}$ and $\delta^{13} \mathrm{C}$ isotopic composition. Nutrient concentrations and physical parameters were measured, and shoreline land uses were assessed in order to ascertain which factors are influential to the isotopic signature. Crabs were collected from shorelines associated with native and non-native marsh grasses, and agricultural land. Based on multiple regression analyses, the $\delta^{13} \mathrm{C}$ is influenced by the shoreline habitat, particularly regarding the marsh grass type. The $\delta^{15} \mathrm{~N}$ signature was enriched slightly, though not significantly so for crabs associated with agricultural land than with marsh grasses, possibly indicating an additional trophic level associated with this location. There were no significant trends in water chemistry variables throughout the creek and, hence, a regression showed no influence between these variables and the stable isotope signature. However, it appears that habitat type may influence the isotopic composition. Studying stable isotopes can be useful to understand the interactions between the crabs and nearshore habitat types, which can influence the development of policy for a sustainable blue crab fishery and ecosystem services.

ADVANCEMENT OF SUNRAY VENUS CLAM, MACROCALLISTA NIMBOSA, AQUACULTURE IN FLORIDA THROUGH EVALUATION OF ALTERNATIVE GROWOUT AND HARVESTING METHODS

Leslie N. Sturmer ${ }^{1}$, William R. White ${ }^{2}$, Todd Z. Osborne ${ }^{3}$, L. Rex Ellis ${ }^{4}$

${ }^{1}$ University of Florida, Cooperative Extension Service, Cedar Key, FL, 32625, USA

${ }^{2}$ University of Florida, School of Forest Resources and Conservation, Cedar Key, FL, 32625, USA

${ }^{3}$ University of Florida, Whitney Laboratory for Marine Bioscience, St. Augustine, FL, 32080, USA

${ }^{4}$ St. Johns River Water Management District, Environmental Sciences, Palatka, FL, 32178, USA

To advance the production of a promising new aquaculture species in Florida, alternative farming technology was evaluated for the sunray venus (SRV) clam Macrocallista nimbosa. Bottom planting under cover nets was more suitable for SRV clams as opposed to bottom bags, the culture method typically used by Florida hard clam growers. An $80 \%$ increase in production was obtained with bottom plants $\left(8.8 \mathrm{~kg} / \mathrm{m}^{2}\right)$ versus bags $\left(4.9 \mathrm{~kg} / \mathrm{m}^{2}\right)$. Product quality of SRV clams harvested from bottom plants was not compromised as breakage, deformities, grittiness after purging, and shelf life did not differ from SRV clams harvested in bags. The use of a pump-driven device to harvest bottom-planted SRV clams was evaluated to determine extent and duration of potential environmental impacts. Of the water quality parameters measured, only turbidity showed any noticeable difference with respect to background conditions. On average, turbidity appeared higher during the harvest of bottom plants and bags than pre- and postharvest intervals of 48 hours; however, statistical differences $(p<0.05)$ were only noted in half of the replicates $(n=4)$. Similarly, 
no significant differences $(p=0.9850)$ were observed between maximum mean values during use of the pump-driven harvester (60.8 $\pm 27.1 \mathrm{NTU})$ and bag harvest ( $60.5 \pm 14.2 \mathrm{NTU})$. Impacts were short-term as turbidity values returned to background levels within 5-9 minutes. Little effect was observed in surface soils with respect to harvest-induced changes in particle size distribution or between harvest and reference (unfarmed) sites. This study provided science-based information to address barriers in establishing the SRV clam as a feasible complement to hard clams.

THE EFFECTS OF FOOD SUPPLY AND ELEVATED $\mathrm{PCO}_{2}$ ON THE EARLY DEVELOPMENT OF THE BAY SCALLOP (ARGOPECTEN IRRADIANS)

Cailan S. Sugano ${ }^{1,2}$, Daniel C. McCorkle ${ }^{1}$, Anne L. Cohen ${ }^{1}$, Lisa M. Milke $^{3}$

${ }^{1}$ Woods Hole Oceanographic Institution, Department of Geology and Geophysics, 266 Woods Hole Road, Woods Hole, MA, 02543, USA

${ }^{2}$ University of California, Santa Barbara, Department of Ecology, Evolution and Marine Biology, Santa Barbara, CA 93117, USA

${ }^{3}$ NOAA, National Marine Fisheries Service, Northeast Fisheries Science Center, 212 Rogers Avenue, Milford, CT, 06460, USA

Oceanic uptake of anthropogenic $\mathrm{CO}_{2}$ is decreasing seawater $\mathrm{pH}$ and calcium carbonate saturation state $(\Omega)$, and recent model simulations suggest that net primary productivity (NPP) in coastal waters of the western North Atlantic will drop during the 21st century. The impact of ocean acidification (OA) and food supply on larval development of the bay scallop Argopecten irradians was investigated. Bay scallop larvae were reared from three hours postfertilization to seven-days-old under a combination of two $\mathrm{CO}_{2}$ levels (ambient and $2200 \mathrm{ppm}$ ) and two feeding rates. Elevated $p \mathrm{CO}_{2}$ had significant negative impacts on growth at both low and high feeding rates, and a low feeding rate reduced growth at both $\mathrm{CO}_{2}$ levels. The two stressors showed no interaction - low food supply did not cause increased sensitivity to elevated $p \mathrm{CO}_{2}$. However, well-nourished larvae reared in high $\mathrm{CO}_{2}$ conditions grew as fast as undernourished larvae reared at ambient $\mathrm{CO}_{2}$ levels, and grew faster than larvae from the low-food high- $\mathrm{CO}_{2}$ treatment. The frequency and severity of shell deformities increased dramatically with elevated $\mathrm{CO}_{2}$, and this effect was moderated by feeding rate; high food supply reduced the frequency of shell deformities by a factor of two. Results confirm the negative impact of acidification on early development of bivalve larvae and highlight the role of nutritional status on larval growth. Efforts to improve forecasting of near-shore OA and NPP changes over the course of this century, combined with laboratory manipulation experiments, will greatly improve projections of shellfish futures.
OCEAN ACIDIFICATION ALTERS EMBRYONIC DEVELOPMENT AND REDUCES THE NUMBER OF VIABLE LARVAE HATCHED AND CALCIFICATION IN SOUTHERN TANNER CRAB, CHIONOECETES BAIRDI

\section{Katherine M. Swiney, W. Christopher Long, Robert J. Foy}

Kodiak Laboratory, Alaska Fisheries Science Center, National Marine Fisheries Service, National Oceanic and Atmospheric Administration, 301 Research Ct., Kodiak, AK, 99615, USA

Ocean acidification, a decrease in ocean $\mathrm{pH}$ due to absorption of anthropogenic $\mathrm{CO}_{2}$, has variable effects on different species. To examine the effects on southern Tanner crab (Chionoecetes bairdi) embryo development, hatching success, and calcification, ovigerous females were reared in one of three treatments: ambient $\mathrm{pH}$ ( 8.1), pH 7.8, and pH 7.5 for two years. Embryos and larvae in year one were from oocytes developed in the field whereas embryos and larvae in year two were from oocytes developed under acidified conditions. Embryo development in ambient and pH 7.8 treatments differed from the $\mathrm{pH} 7.5$ treatment, but not each other. Differences in embryo morphology were slight in year one, averaging 3.6\%. In year two, the embryos in the $\mathrm{pH} 7.5$ treatment had $10.1 \%$ larger yolks and $6.3 \%$ smaller embryos than in the ambient treatment. The number of viable larvae hatched did not differ with treatment in year one and in year two did not differ between ambient and $\mathrm{pH} 7.8$ treatments, but on average $71 \%$ fewer viable larvae hatched in the $\mathrm{pH} 7.5$ treatment. Percent calcium in female's carapaces was lower in $\mathrm{pH} 7.5$ than the other treatments at the end of the experiment. The results from this two year study suggest that projected ocean $\mathrm{pH}$ levels within the next two centuries will likely have a pronounced impact on southern Tanner crab populations unless the crab are able to acclimatize or adapt to rapidly changing conditions.

\section{NATURAL RECOVERY OF AN EASTERN OYSTER POPU- LATION FROM A CATASTROPHIC EVENT AND ITS IMPLICATIONS FOR RESTORATION PLANNING \\ Mitchell Tarnowski}

Shellfish Division, Maryland Department of Natural Resources, 580 Taylor Ave., B-2, Annapolis, MD, 21401, USA

The Little Choptank River was once a highly productive oyster growing tributary of the Chesapeake Bay on Maryland's eastern shore, so much so that the state established seed-oyster production areas for subsequent transplanting to low recruitment regions. In the 1980 s and early 1990s, seasonal harvests were as high as 84,000 bushels and seed-oyster production peaked at 309,000 bushels. A series of epizootics from the mid1980 s through the early 2000 s severely impacted this oyster population, culminating in an observed mortality of $92 \%$ in 2002 , the final year of a 4-year drought. Initially, recovery was slow, but an extended period of low disease-related mortality in conjunction with several years of favorable recruitment 
beginning in 2006 has resulted in natural oyster densities of 28 oysters $/ \mathrm{m}^{2}$, almost double the threshold for what is considered to be a restored population. Recovery was further enhanced by prohibiting harvesting through the establishment of a sanctuary in 2010 encompassing a majority of the oyster bars. By 2013, relative densities were comparable to those in the early 1980s. This natural recovery is currently being supplemented by restoration activities, including fossil shell plantings to enlarge the habitat footprint and the addition of hatchery seed oysters. Such restoration efforts should be informed by the oyster population dynamics of the region. In the case of the Little Choptank River with its strong recruitment potential, a valuable resource such as hatchery seed may have been put to better use in another tributary where natural reproduction is lower.

RECRUITMENT, SURVIVAL, AND GROWTH OF THE OLYMPIA OYSTER (OSTREA LURIDA) AND THE JAPANESE OYSTER (CRASSOSTREA GIGAS) AS A FUNCTION OF TIDAL HEIGHT

Rick Torres, Thomas Parker, Jennifer Burnaford, Danielle Zacherl

California State University Fullerton, Department of Biological Science, Fullerton, CA, 92831, USA

Surveys of seawalls in southern California bays have uncovered zonation of native (Ostrea lurida) and non-native (Crassostrea gigas) oysters, where non-natives reach their maximum density higher in the intertidal zone than natives. This zonation may be explained through differences in settlement, recruitment, and/or growth and survival across species. The effects of varying tidal heights on recruitment, survival, and growth of native and nonnative oysters in San Diego Bay, California were explored during Summer and Fall 2014. To assess recruitment levels, twenty ceramic tiles were placed onto a fence at varying tidal heights and replaced every two weeks for five months. To measure growth and survival, ten ceramic tiles, each with ten recently settled native oysters and two to four non-native oysters, were transplanted to varying tidal heights from $-0.25 \mathrm{~m}$ MLLW to $+1 \mathrm{~m}$ MLLW and checked periodically for 14 weeks. Increased tidal height significantly reduced recruitment of both species, with a more significant decline for native oysters. After 14 weeks, native oysters experienced $100 \%$ mortality at all tidal heights; non-native oysters survived throughout the tidal range. Growth of both native and non-native oysters was not significantly affected by tidal height, but non-natives showed a trend toward faster growth at lower tidal heights. Recruitment patterns alone may explain adult zonation patterns for $O$. lurida, but further studies are required to understand why $C$. gigas is not achieving higher densities at lower tidal heights. Results will help facilitate installation of restoration beds at tidal heights that maximize native performance and minimize non-native performance.
PREDATION FROM BOTH STARFISH (ASTERIAS RUBENS) AND EIDERS (SOMATERIA MOLLISSIMA) ON SUSPENDED MUSSELS (MYTILUS EDULIS) IN AN INTEGRATED MARICULTURE PRODUCTION IN INNER DANISH WATERS

Ditte Tørring, Per Andersen, Per Dolmer, Jonathan Carl, Christina Soegren, Mathilde Pedersen

Orbicon, Dept. of Water and Nature Resources, Jens Juulsvej 16, 8260 Viby Denmark

Production of suspended mussels (Mytilus edulis) has been heavily affected by predation from both starfish (Asterias rubens) and eiders (Somateria mollissima) in an integrated cultivation of mussels to extract nutrients from the environment to counter balance the release of nutrients during the mariculture production of rainbow trout (Oncorhynchus mykiss) in the inner Danish waters. An investigation of starfish larvae density and its developmental stage showed the timing between mussel and starfish larvae on suspended nets is central to the magnitude of predation on the newly settled mussels thus impacting recruitment. Experiments investigating the predatory impact from eiders on suspended mussels indicated: 1) Eiders prefer to forage on the edge of the production area, 2) A large proportion of the suspended mussels fall to the seabed during foraging, 3) The number of feeding eiders is greater in the morning and afternoon in comparison to the middle of the day, and 4) There was a greater predation pressure by eiders on mussels in a protective bay compared to a more exposed area and 5) There was no difference in the their feeding intensity in relation to weather. There is no doubt that predation by starfish and eiders, and the success of combatting their influence on mussel production, can be a critical factor for the success of using mussel production as a compensatory tool for balancing the release of nutrients in aquaculture. Mitigation measures are discussed.

\section{ASSESSING THE BENEFITS OF OYSTER REEF RESTORA- TION IN THE CHESAPEAKE BAY}

Howard Townsend ${ }^{1}$, David Bruce ${ }^{1}$, Philip Klavon², Jay Lazar², Giselle Samonte ${ }^{3}$, Andrew Turner ${ }^{2}$

${ }^{1}$ NOAA $\backslash$ NMFS $\backslash$ Habitat Conservation - Chesapeake Bay Office, Cooperative Oxford Laboratory, Oxford, MD, USA

${ }^{2}$ NOAA $\mid$ NMFS $\backslash$ Habitat Conservation - Chesapeake Bay Office, Annapolis, MD, USA

${ }^{3}$ NOAA $\backslash$ NMFS $\backslash$ Habitat Conservation, Silver Spring, MD, USA

In the Chesapeake, oyster reefs provide a wide range of ecosystem services (e.g., water filtration, nutrient sequestration and removal, provision of food and habitat for commercially valuable species). To assess the habitat benefits of oyster restoration, a long-term project was developed to quantify the ecological production functions and estimate the value of these re-established ecosystem services. Ecological studies and modeling of fish biomass are being used to estimate the production of fish biomass 
supported by oyster reefs and assess changes in production attributable to improves in habitat associated with oyster reefs. In the first years of the study, baseline assessments of the habitat and finfish communities were conducted in the mid-eastern shore reefs before the implementation of restoration in control sites and sites where restoration will begin. As would be predicted in the "before" portion of a before-after control-intervention study design, no appreciable difference in habitat or finfish community structure are observed between treatment and paired controls. However, it is anticipated that after the restoration implementation is completed, appreciable differences will be measured. A generalized oyster reef ecosystem model (OREM) of a Chesapeake oyster reef was also developed based on literature review. This model in combination with habitat suitability models and data from field studies will be used to create ecological production functions for oyster reef fish production. In turn, this model will provide input for economic models to estimate the commercial and recreational value of fish production associated with oyster reefs.

GENETIC CONNECTIVITY OF CRASSOSTREA VIRGINICA: THE INFLUENCE OF HYDRODYNAMICS ON THE POPULATION GENETICS OF A RESTORATION PROJECT IN THE LAFAYETTE RIVER, VIRGINIA

Brendan Turley ${ }^{1}$, Jackie Shannon ${ }^{2}$, Thomas Leggett ${ }^{2}$, Jan McDowell, Kimberly Reece ${ }^{1}$

${ }^{1}$ Virginia Institute of Marine Science, College of William and Mary, P.O. Box 1346, Gloucester Point, VA, 23062, USA

${ }^{2}$ Chesapeake Bay Foundation, P.O. Box 412, Wicomico, VA, 23198, USA

Eastern oyster larvae can live as plankton for three weeks and during this time they are subject to dispersal by currents and tides. Consequently, oyster larvae have high potential for dispersal, which may connect geographically distinct reefs and limit the magnitude of population genetic structuring. Larval dispersal can impact an oyster restoration project in a tidally dominated river (e.g. Lafayette River) in several ways: (1) larvae produced by planted oysters maybe retained within the system until settlement, (2) larvae maybe transported out of the system and settle elsewhere, and (3) larvae produced outside the system may be transported into the system and settle. The first possibility appeals to restoration managers, but is challenging to predict and study. A coupled biologicalhydrodynamic model was used to determine where oyster larvae produced in the Lafayette River would settle within the river. To test the predictions of the model, two genetically distinct strains of oysters were planted on two separate reefs in 2013. A genetic survey was conducted on oysters sampled from the Elizabeth, James, and Lafayette Rivers, which are hydro-dynamically linked, and from the planted restoration strains to establish baseline genetic differences between populations using single nucleotide polymorphism loci (SNPs). Spat collectors were used to capture newly spawned oysters settling within the Lafayette River. Spat were genotyped at the SNP loci and the data was used to assign spat to likely source populations. Restoration project managers will use results of this study to modify restoration plans in the Lafayette River.

INDUCTION OF TRIPLOIDY IN THE PURPLE-HINGED ROCK SCALLOP CRASSADOMA GIGANTEA (GRAY, 1825) Brent Vadopalas $^{1}$, Molly Jackson ${ }^{1,2}$, Jonathan P. Davis ${ }^{2}$

${ }^{1}$ School of Aquatic and Fishery Sciences, University of Washington, Seattle, WA, 98195, USA

${ }^{2}$ Taylor Shellfish Co., 701 Broadspit Road, Quilcene, WA, 98376, USA

The Purple-hinged rock scallop (Crassadoma gigantea), a species with enormous market potential in all four U.S. states bordering the Pacific Ocean, is sparsely distributed which essentially precludes commercial fisheries. Interest in rock scallop aquaculture is rising, but culture of native species close to wild conspecifics can result in negative genetic effects on wild populations. One solution is to culture populations that are effectively sterile. To initiate an investigation of the use of ploidy manipulation to induce sterility in rock scallops, a series of trials to optimize triploid induction were conducted. We compared survival and ploidy from groups of rock scallops treated with eight concentrations of 6-dimethylaminopurine (6-DMAP) to block extrusion of the second polar body during meiosis. In a series of initial trials, survival ranged between 5 and $40 \%$ of untreated controls, and the percentage of triploids ranged from $10-70 \%$. An optimal treatment of $425 \mu \mathrm{M}$ 6-DMAP for $15 \mathrm{~min}$, commencing at approximately $60 \mathrm{~min}$ post-fertilization at $17{ }^{\circ} \mathrm{C}$ was determined. Future work will include production of diploid and triploid rock scallop seed for larger scale trials to compare growth, reproductive status, and survival at multiple growout sites, and development of tetraploid rock scallops for production of bred triploids.

INDICATIONS OF RECOVERY TRENDS IN THREE SPECIES OF ABALONE IN CALIFORNIA, WITH APPARENT LINKAGES TO OCEAN-SCALE TEMPERATURE ANOMALIES

Glenn R. VanBlaricom ${ }^{1}$, Melissa J. Neuman², David A. Witting ${ }^{3}$

${ }^{1}$ US Geological Survey, Washington Cooperative Fish \& Wildlife Research Unit, School of Aquatic and Fishery Sciences, University of Washington, mailstop 355020, Seattle, WA, 98195 , USA

${ }^{2}$ NOAA/NMFS West Coast Region, 501 W Ocean Blvd., Suite 4200, Long Beach, CA, 90802, USA

${ }^{3}$ NOAA/NMFS Restoration Center, 501 W Ocean Blvd., Suite 4470, Long Beach, CA, 90802, USA

All commercial harvests of abalone (Haliotis spp.) in California were legislatively terminated in 1996 because of depleted popula- 
tions. Since $\sim 2000$ the previously significant warming trend in northeastern Pacific surface waters, including the entire geographic ranges of black (H. cracherodii Leach, 1814), green (H. fulgens Philippi, 1845), and pink (H. corrugata Wood, 1828) abalone, has stalled, coinciding with a phase shift from positive to negative in the Interdecadal Pacific Oscillation (IPO). Regional sea surface temperatures have declined at $0.06-0.08^{\circ} \mathrm{C}$ per year, with sequestration of heat primarily deeply subsurface (300-700 $\mathrm{m}$ and deeper). Black abalone populations experienced mass mortalities beginning in 1985, resulting from the disease, withering syndrome (WS), and were listed as "endangered" in 2009. WS caused $95-99 \%$ reductions in black abalone numbers at San Nicolas Island, California after 1992, but recruitment success began increasing in 2001 following the IPO phase shift, with population sizes since increasing substantially on some portions of the Island. Green and pink abalone abundances declined precipitously in Southern California during the 1970s due to overharvest and poaching. Commercial landings of both species fell to $\leq 6 \%$ of historic peak catches. Fishery-independent surveys and anecdotal observations suggest that abundances of both green and pink abalone have increased following the IPO phase shift. We suggest that shellfishery managers and marine conservation interests recognize the potential value of current ocean conditions for implementing policies and actions to recover depleted and imperiled populations of black, green, and pink abalone and possibly other abalone species of the northeastern Pacific as well.

USING SUBSURFACE DRIFTERS TO TRACK NORTHERN QUAHOG MERCENARIA MERCENARIA LARVAL DISTRIBUTION PATTERNS IN NARRAGANSETT BAY

Pandora Wadsworth $^{1}$, Scott Rutherford ${ }^{1}$, Dale Leavitt ${ }^{1}$, David Ullman ${ }^{2}$

${ }^{1}$ Roger Williams University, 1 Old Ferry Road, Box \#7321, Bristol, RI, 02809, USA

${ }^{2}$ University of Rhode Island, Graduate School of Oceanography, Narragansett, RI, 02882, USA

Throughout Narragansett Bay the abundance of adult quahogs and reproductive communities varies according to larval dispersal and settlement patterns as well as post-settlement processes. Knowledge of these patterns is crucial to maintaining spawning sanctuaries and managing the degree of harvest pressure from commercial and recreational fisheries. To track hydrodynamic conditions, Lagrangian subsurface drifters were deployed at six locations throughout Narragansett Bay during the seasonal spawning period. The drifter tracks showed unique hydrodynamic patterns at each deployment site and implied differences in the rate of water exchange and resulting bivalve larval dispersal. At the primary convergence site between the East and West passages of Narragansett Bay, the drifter tracks indicate a random mixing pattern. At other deployment sites the drifter tracks either showed extensive water exchange and therefore widespread larval dispersal, or remained near the release site and suggested limited water exchange and/or high larval settlement. In addition, locations in the Bay where the drifters frequently ran aground suggest potential larval sinks. The in situ drifter tracks were compared to passive particle transport simulated by a Regional Ocean Modeling System (ROMS) applied to Narragansett Bay. The comparability between the modeling systems varied greatly between sites, with some deployment sites showing very similar projected dispersal patterns and other sites showing significant differences. Model results estimate $35-90 \%$ of larvae are lost from the Bay resulting in significant implications for the placement of spawning sanctuaries.

FAST SHELLS AND SLOW SHELLS: OCEAN ACIDIFICATION AND SEASHELLS IN BIVALVE LARVAE

George G. Waldbusser ${ }^{1}$, Burke Hales ${ }^{1}$, Matthew Gray ${ }^{2}$, Chris J. Langdon $^{2}$, Brian Haley ${ }^{1}$, Elizabeth L. Brunner ${ }^{1}$, Cale Miller ${ }^{3}$, Iria Gimenez $^{1}$, Greg Hutchinson ${ }^{2}$

${ }^{1}$ Oregon State University, College of Earth, Ocean, and Atmospheric Sciences, 104 COAS Administration Bldg., Corvallis, OR, 97331, USA

${ }^{2}$ Coastal Oregon Marine Experimental Station and Department of Fisheries and Wildlife, Hatfield Marine Science Center, Oregon State University, 2030 SE Marine Science Drive, Newport, OR, 97365, USA

${ }^{3}$ Oregon State University, Department of Fisheries and Wildlife, 104 Nash Hall Oregon State University, Corvallis, OR, 97331, USA

Bivalve larvae are generally known to be particularly sensitive to ocean acidification (OA) during prodissoconch I shell formation due to the greater connectivity of the calcifying fluid to the external environment, limited maternal energy reserves, and the rapid rate at which they must form their first shell. It has recently been shown that during this initial period of shell formation some species of bivalve larvae are directly sensitive to calcium carbonate saturation state $(\Omega)$, not $\mathrm{pH}$ or $p \mathrm{CO}_{2}$. Further, this $\Omega$ sensitivity occurs under $\mathrm{OA}$ projections that are decades, not centuries, in the future, highlighting the importance of this OA response mechanism. Although others have documented developmental stages of various bivalve larvae, there is little quantification of calcification rate of the prodissoconch I shell during the transition from trochophore to veliger larvae; the stage that appears most sensitive to ocean acidification. If the model previously proposed is correct, then if bivalve larvae develop their shell more slowly, a decrease in sensitivity to decreased saturation state is anticipated. Unique chemical manipulations of the marine carbonate system, high precision measurements of calcium in developing shells, and a variety of other techniques were utilized to compare responses of two oyster species, Crassostrea gigas and Ostrea lurida to acidification and documented the calcification rates of their prodissoconch I shells. Results demonstrate a strong link between calcification rate and acute sensitivity to saturation state during prodissoconch I shell development, with the slower-calcifying $O$. lurida exhibiting markedly less sensitivity to OA than the faster $C$. gigas. 
CRITICAL TEMPERATURE THRESHOLDS CAN BE USED TO SELECT OPTIMAL WHITE ABALONE OUTPLANTING SITES

Benjamin Walker ${ }^{1}$, Cynthia Catton ${ }^{2}$, Laura Rogers-Bennett ${ }^{1,2}$

${ }^{1}$ University of California, Bodega Marine Laboratory, P.O. Box 247, Bodega Bay, CA, 94923, USA

${ }^{2}$ California Department of Fish and Wildlife, Bodega Marine Laboratory, 2099 Westside Road, Bodega Bay, CA, 94923, USA

White abalone (Haliotis sorenseni) were fished to the brink of extinction and listed as endangered in 2001. As broadcast spawners, these invertebrates are unlikely to successfully reproduce given their small population sizes. The white abalone recovery plan lists captive breeding as a top priority to restore populations of this endangered species. A partnership, led by the University of California Davis and the California Department of Fish and Wildlife, is currently breeding this species with the intention of restocking. In order to identify optimal sites for potential outplanting, temperature data from several sites in southern California that historically supported white abalone populations were analyzed. The current environmental suitability of each site within the context of optimal temperature ranges for multiple life-history stages and times of the year: disease susceptibility (yearround), gonad development for reproduction (October to February), and larval development during the spawning season (March to May) were assessed. Suboptimal temperature thresholds were identified using experimental observations from white abalone and red abalone (a close congener). After evaluating temperature data from each site, a suitability matrix was created to assess the environmental conditions of potential outplanting locations to help prioritize optimal sites for restoration of the critically endangered white abalone.

\section{EFFECTS OF STOCKING DENSITY IN THE NURSERY AND THE FIELD ON EASTERN OYSTER, CRASSOSTREA VIR- GINICA, GROWTH, AND SHAPE \\ William Walton, Eric Stewart}

Auburn University Shellfish Laboratory, 150 Agassiz Street, Dauphin Island, AL, 36528, USA

Based on concerns about the shape of oyster seed (Crassostrea virginica) received by growers upon the final product, we are conducting a field test of the effect of three different stocking densities ('standard', $1 / 2$ standard, and $2 \times$ standard) in the nursery crossed with three different stocking densities subsequently in the field, where all reductions in stocking densities in the standard treatments were mirrored in the other two treatments. The nursery work was conducted in land-based upwellers at Auburn University Shellfish Laboratory on Dauphin Island, Alabama during the summer of 2014, and the field work is being carried out in Portersville Bay, Alabama. Average size, cup (ratio of shell width to shell height), fan (ratio of shell length to shell height) and their respective coefficients of variation of seed over time are being tracked by treatment, with individually tagged oysters in each field treatment followed as well. There were clear differences in average size amongst nursery treatments, though differences in shape amongst treatments were less obvious. Results to date for field deployments will be reported as well. This is the first effort to document allometric changes in oyster morphology.

\section{THE GULF SHELLFISH INITIATIVE: A REGIONAL CHAL-} LENGE AND OPPORTUNITY

William C. Walton ${ }^{1}$, Chris Nelson ${ }^{2}$, Alfred Sunseri ${ }^{3}$, LaDon Swann ${ }^{1}$

${ }^{1}$ Auburn University School of Fisheries, Aquaculture \& Aquatic Sciences, AUSL, 150 Agassiz St., Dauphin Island, AL 36528

${ }^{2}$ Bon Secour Fisheries, Bon Secour, AL 36511

${ }^{3}$ P\&J Oyster, New Orleans, LA 70112

Shellfish, particularly oysters, are a critical ecological, economic and cultural resources in the Gulf of Mexico. The Gulf Shellfish Initiative (GSI) unites the National Oceanic and Atmospheric Administration's (NOAA) National Shellfish Initiative and the five State's interest in promoting a critical clean water industry that supports the region's economy and culture. The initiative is intended to protect and enhance a resource that is critical for jobs, industry and citizens. The draft GSI includes four objectives: 1) Ensure Clean and Plentiful Water to Protect and Enhance Shellfish Beds, 2) Promote Commercial Shellfish Harvest, 3) Create a Public/Private Partnership for Shellfish Aquaculture, and 4) Promote Ecosystem Services Provided by Shellfish. A regional approach presents both challenges and opportunities. Currently, the draft is being shared with various stakeholders to gather input and generate a GSI that promotes a comprehensive approach to stock enhancement, aquaculture and traditional restoration.

\section{DECISION-MAKING IN THE FACE OF UNCERTAINTY: AN EVALUATION OF PINTO ABALONE UNDER THE ENDAN- GERED SPECIES ACT}

Susan Wang ${ }^{1}$, Melissa Neuman', Shallin Busch², Carolyn Friedman $^{3}$, Kristen Gruenthal ${ }^{4}$, Rick Gustafson ${ }^{4}$, David Kushner ${ }^{5}$, Kevin Stierhoff $^{6}$, Glenn VanBlaricom ${ }^{3,7}$, Sadie Wright ${ }^{8}$

${ }^{1}$ National Marine Fisheries Service (NMFS) West Coast Region, Long Beach, CA, USA

${ }^{2}$ National Ocean Service, Silver Spring, MD, USA

${ }^{3}$ University of Washington, Seattle, WA, USA

${ }^{4}$ NMFS Northwest Fisheries Science Center, Montlake, WA, USA

${ }^{5}$ National Park Service, Ventura, CA, USA

${ }^{6}$ NMFS Southwest Fisheries Science Center, La Jolla, CA, USA

${ }^{7}$ U.S. Geological Survey, Seattle, WA, USA

${ }^{8}$ NMFS Alaska Region, Juneau, AK, USA

Under the Endangered Species Act (ESA), the National Marine Fisheries Service (NMFS) is charged with making timely 
decisions on the status of species based on the best available information, which is typically incomplete and limited by uncertainties. The often controversial nature of these decisions is an added challenge. Approaches to decision-making in the face of these challenges will be discussed, focusing on the recent ESA review and listing decision for pinto abalone (Haliotis kamtschatkana). In 2013, two petitions were received to list pinto abalone under the ESA, initiating a formal 12-month process to review and develop a finding on the status of the species. The species' wide distribution (from Baja California to Alaska) and varying levels of monitoring effort throughout this range resulted in a high degree of uncertainty regarding the species' status currently and into the foreseeable future. Questions regarding the potential threat of expanding sea otter populations and ocean acidification impacts added to this uncertainty. The decisions that must be made and how the status review team incorporated empirical data, qualitative information, and best expert judgment to assess the species' extinction risk in the face of high uncertainty will be outlined. The result was a comprehensive review of the species' status highlighting the value of long-term monitoring to these assessments and identifying important data gaps. By providing a clearer understanding of decision-making under the ESA, the hope is to promote more effective, meaningful participation by the public, particularly the scientific and fishing communities, in these decisions.

\section{VARIANCE IN RECRUITMENT OF OLYMPIA OYSTERS ACROSS WEST COAST ESTUARIES}

Kerstin Wasson', Andrew L. Chang ${ }^{2}$, Anna Deck ${ }^{3}$, Paul Dinnel ${ }^{4}$, Sarah Dudas ${ }^{5}$, Matthew Ferner ${ }^{3}$, Ted Grosholz ${ }^{6}$, Jennifer Ruesink ${ }^{7}$, Alan Trimble ${ }^{7}$, Dick Vander Schaaf ${ }^{8}$, Chela Zabin ${ }^{2,6}$, Danielle Zacherl' $^{9}$

${ }^{1}$ Elkhorn Slough National Estuarine Research Reserve, Watsonville, CA, 95076, USA

${ }^{2}$ Smithsonian Environmental Research Center, Tiburon, CA, 94920, USA

${ }^{3}$ San Francisco Bay National Estuarine Research Reserve, Tiburon, CA, 94920, USA

${ }^{4}$ Skagit County Marine Resources Committee, Mount Vernon, WA, 98273, USA

${ }^{5}$ Center for Shellfish Research, Nanaimo, BC, V9R 5S5, Canada

${ }^{6}$ Department of Environmental Science and Policy, University of California Davis, Davis, CA, 95616, USA

${ }^{7}$ University of Washington, Seattle, WA, 98195, USA

${ }^{8}$ The Nature Conservancy of Oregon, Portland, OR, 97214, USA

${ }^{9}$ California State University Fullerton, Fullerton, CA, 92831, USA
Recruitment of juveniles into the adult population is essential for population replenishment, as highlighted by the conceptual framework of "supply-side ecology." Olympia oyster (Ostrea lurida) conservation and restoration depends on an understanding of recruitment dynamics. Researchers across many West Coast estuaries have established long-term monitoring programs that track Olympia oyster recruitment. The first synthesis and comparison of Olympia oyster recruitment across estuaries ranging from southern California to British Columbia were conducted to test several hypotheses about recruitment dynamics. Interannual variance in recruitment is predicted to be greater at smaller and/or more isolated estuaries, where the entire population faces similar environmental conditions in a given year, than at larger or interconnected estuaries that experience more geographic variation in environmental conditions. Results support this prediction, revealing that small estuaries or isolated populations frequently have years with zero recruitment, while larger estuaries or interconnected populations do not. It was also predicted that regional atmospheric/oceanographic drivers result in synchrony of good/ bad years at neighboring estuaries experiencing similar conditions. The results do not support that prediction; there was no synchrony in "good years" vs. "bad years" along the coast, even at neighboring estuaries, suggesting local drivers of recruitment overshadow regional drivers. Our results will inform site-selection and restoration strategies for Olympia oysters along this coast.

USING PARTICIPATORY MODELLING TO HELP SEAFOOD PRODUCERS ON THE UNITED STATES EAST COAST IDENTIFY WAYS TO ADAPT TO A CHANGING CLIMATE

Thomas Webler ${ }^{1}$, Seth Tuler $^{2}$, Jessica Whitehead ${ }^{3}$, Esperanza Stancioff ${ }^{4}$, Elizabeth Fly ${ }^{5}$, Brian Seitzman ${ }^{1}$, Julie Davis ${ }^{6}$

${ }^{1}$ Social and Environmental Research Institute, Greenfield, MA, USA

${ }^{2}$ Interdisciplinary and Global Studies Division, Worcester Polytechnic Institute, 100 Institute Road, Worcester, MA, 01609, USA

${ }^{3}$ North Carolina Sea Grant, 1575 Varsity Dr., Campus Box 8605, North Carolina State University, Raleigh, NC, 27695-8605, USA

${ }^{4}$ University of Maine Cooperative Extension/Maine Sea Grant, 377 Manktown Rd., Waldoboro, ME, 04572, USA

${ }^{5}$ South Carolina Sea Grant Consortium and Carolina Integrated Sciences and Assessments, 287 Meeting Street, Charleston, SC, 29401, USA

${ }^{6}$ South Carolina Sea Grant Consortium, 102 Industrial Village Road, PO Box 189, Beaufort, SC, 29901, USA

Using the Vulnerability, Consequences, and Adaptation Planning Scenario (VCAPS) approach and systems dynamics (SD) 
modeling, local citizens in three Atlantic Coast communities identified climate stressors impacting their fishery and devised adaptive actions that could be taken to ensure financial stability in the face of a changing climate. Workshop participants included fishermen, shellfish farmers, extension staff, planners, resource managers, and scientists. In Maine, rising water temperatures impact lobster molt cycles and movement of lobsters to deeper water. Various fishing effort scenarios were modelled to demonstrate how this may affect a lobsterman's timing and duration of fishing effort and income. With rising air and water temperatures in Massachusetts, the oyster industry is concerned about increased incidence of illness from Vibrio. A model, developed with information contributed by growers, provided an opportunity for oystermen to anticipate possible costs of compliance with new regulations, public risk perception, and impacts of future closures. In South Carolina, the blue crab fishery has faced extended periods of drought throughout the past decade. Vulnerabilities of blue crabs to drought were diagrammed and key data gaps identified. This led to creation of the 'Crabbers Who Care Research Network' which will help fill data poor areas of an ecosystem-based business management tool. Tools and discussion generated in each community by this NOAA Coastal and Ocean Climate Applications Program-funded project will help fishermen on an individual business management level while also fostering communication about climate related changes in fisheries and fishery-related policy.

THE ECOSYSTEM SERVICE VALUE OF NITROGEN REMOVAL THROUGH BIOEXTRACTION IN LONG ISLAND SOUND

Katharine Wellman

Northern Economics, Inc., 1455 NW Leary Way Suite 400, Seattle, WA, 98107, USA

This presentation will provide a discussion of the ecosystem service benefits of bioextraction based on a literature review prepared by Northern Economics (2012) and an analysis of the economic value of nitrogen removal by bioextraction using the replacement cost or cost-avoided method. The case study area described is Long Island Sound, New York (LIS) with a focus on oyster and clam aquaculture. A related policy question considered is whether or not shellfish producers should be included in the current Connecticut Department of Energy and Environmental Protection Nitrogen Credit Exchange. The focus of this work is on the ecosystem service of nitrogen removal provided by shellish bioextraction - the harvest of cultured oysters and clams. We apply a cost-based method - the cost-avoided method - that estimates values of ecosystem services based on the costs of avoiding damages due to lost services. This method does not provide strict measures of the economic value of ecosystem services, but rather provides a rough indicator of the value by assuming that, if people incur costs to avoid damages caused by lost ecosystem services, or to replace the services of ecosystems, then those services must be worth at least what people paid to protect or replace them. In this case, we measure the costs of alternative nitrogen removal approaches that would be necessary if it were not for bioextraction provided by the shellfish aquaculture industry. Our analysis suggests that the ecosystem service of nitrogen removal through bioextraction provides significant value. The average value of nitrogen removal through bioextraction ranges between $\$ 1.8$ million to $\$ 132$ million in LIS, depending on assumptions of current and potential acres in shellfish production and nitrogen effluent limits.

FEEDING INTERACTIONS OF COHABITING BIVALVE MOLLUSCS: A STUDY OF INTERSPECIFIC RELATIONSHIPS AND THEIR POTENTIAL AFFECTS ON THE FUTURE OF SHELLFISH AQUACULTURE AND RESTORATION

\section{Amanda A. Wenczel, David Bushek}

Haskin Shellfish Research Laboratory, Rutgers University, 6959 Miller Avenue, Port Norris, NJ, 08349, USA

Cohabitating bivalve molluses are common within estuarine waters where they may compete for or partition limited resources. When shellfish populations are enhanced or altered through fisheries management actions, restoration, or aquaculture, do interspecific interactions unintentionally intensify? This study explores the feeding interactions of two species of interest along the eastern seaboard of North America: the ribbed mussel Geukensia demissa, an increasingly popular species within restoration initiatives; and the eastern oyster Crassostrea virginica, a species consistently vital to the economy and ecology of the region. Particle removal rates and efficiencies were obtained via controlled closed system experiments as well as through the discrete sampling of flow through raceways. Bivalves in closed systems were batchfed Tisochrysis lutea (T-ISO) and depletion monitored for 40 minutes. In raceways, raw seawater was sampled upstream and downstream of bivalves at three time intervals after animals had begun filtering. Filtration was examined separately for each species and in serial combinations. Results showed no identifiable species effect, but a clear effect of particle removal by the bivalves. Preliminary observations indicate a positive relationship between oyster particle removal efficiency and time within experimental system. Additionally, experimental systems with cohabitating oysters and mussels adapted to constant submergence showed marginally greater removal than those containing either species alone or those units with cohabitating oysters and intertidal mussels. These early results point to feeding differences based on intertidal vs. subtidal habitat location, not species. Further analyses of these results as well as the implications for future restoration and multispecies aquaculture will be discussed. 


\section{LARGE-SCALE OYSTER RESTORATION IN CHESA- PEAKE BAY}

Stephanie Reynolds Westby ${ }^{1}$, David Bruce ${ }^{1}$, Kimberly Gross ${ }^{2}$, Jay Lazar', Kara Muzia ${ }^{3}$, Ken Paynter ${ }^{4}$, Angela Sowers ${ }^{2}$, Ward Slacum $^{3}$, Howard Townsend ${ }^{1}$, Eric Weissberger ${ }^{5}$

${ }^{1}$ National Oceanic and Atmospheric Administration, $410 \mathrm{Sev}-$ ern Ave., Annapolis, MD, 21403, USA

${ }^{2}$ U.S. Army Corps of Engineers, Baltimore District, 10 South Howard Street, Baltimore, MD, 21202, USA

${ }^{3}$ Oyster Recovery Partnership, 1805A Virginia Street, Annapolis, MD, 21401, USA

${ }^{4}$ University of Maryland, Marine, Environmental and Estuarine Program, 1213 HJ Patterson Hall, College Park, MD, 20742, USA

${ }^{5}$ Maryland Department of Natural Resources, Fisheries Service, 580 Taylor Avenue B2, Annapolis, MD, 21403, USA

Chesapeake Bay oyster populations stand at less than one percent of historic levels, and ecosystem services provided are similarly diminished. Overlapping state and federal policy agendas call for restoring oyster populations in ten Chesapeake Bay tributaries by 2025 . Driven by these initiatives, state, federal, and NGO partners, advised by a group of scientific experts, have formed a working group to select Maryland tributaries for restoration and develop science-based oyster restoration plans for each. The first selected tributary is Harris Creek, a 1,829hectare oyster sanctuary in Maryland, USA. A restoration plan was developed based on acoustic seafloor surveys, water quality data, oyster population surveys, and scientific expert and citizen input. The plan details suitable restoration sites, oyster seed and reef substrate requirements, and costs. The plan calls for the restoration of more than 140 hectares of oyster reef in the creek, representing one of the largest oyster restoration projects, by area, undertaken on the Atlantic coast. Reef-level and tributary-level oyster restoration success criteria were previously established for the Chesapeake; this plan calls for restoration to meet these criteria. Two-thirds of the area slated for restoration has been constructed; completion is expected in 2015. The initial acoustic seafloor and oyster population surveys will serve as baselines to evaluate restoration progress. Monitoring is ongoing; early results are promising. A study is underway to quantify restored reef denitrification rates and patterns of nekton use, including economic valuation of these services. Other Chesapeake Bay tributaries are targeted for restoration on a similar scale.

AGE DETERMINATION OF RED DEEP-SEA CRAB ( $\mathrm{CHA}$ CEON QUINQUEDENS) BY GROWTH RING ANALYSIS

\section{Justin L. Wilson, Bradley G. Stevens}

University of Maryland Eastern Shore, Princess Anne, MD, 21853, USA

The age structure and growth rates of crustaceans are poorly understood because of the lack of true skeletal structures (e.g. shells, scales, otoliths) that form annual growth rings. A recent development in crustacean aging is the discovery of growth rings, or bands, in calcified sections of the eyestalk and gastric mills. By examining these structures, more accurate age estimates can be determined. The study focused on the red deep sea crab (Chaceon quinquedens), which supports a minor commercial fishery along the Atlantic continental shelf and slope of North America, in waters from 200 to 1800 meters and temperatures of 5 to $8^{\circ} \mathrm{C}$. Red crabs are a data poor stock, due to insufficient data on their biology, abundance, growth, age, and reproduction. Eyestalks and gastric mills were removed, cleaned and embedded in epoxy, then sectioned longitudinally using a diamond-bladed Isomet saw. Sections were mounted, polished, and viewed with a compound microscope. Rings were counted and compared between structures, and between paired eyestalks. Estimates of age composition can be used to improve data on growth, recruitment, migration, maturation, longevity and mortality, and will contribute greatly to improved stock assessment for this species.

\section{AN OVERVIEW OF CALIFORNIA SHELLFISH ACTIVITIES Diane Windham}

NOAA Fisheries West Coast Region, 1315 East West Highway, SSMC3, Suite 12605, Slver Spring, MD, 20910, USA

In response to the NOAA National Shellfish Initiative, the Administration's National Ocean Implementation Plan, and various other state shellfish initiatives, interest and activity related to increasing sustainable commercial shellfish production and wild shellfish restoration has grown notably in California. An overview of these activities, which range from development of a CA Shellfish Initiative (CSI) that includes regionally specific pre-permitting projects, to offshore shellfish projects in state and federal waters, to coastal and bay shellfish restoration projects, will be provided. These activities will contribute to "blue job" creation, re-invigorate coastal economies, and provide a safe and healthy seafood product locally grown, not imported. There are regulatory challenges and innovations, and also exciting technologies being explored. Current demand for shellfish product in CA cannot currently be met by existing operations, but there is great interest in expansion and encouraging new start-up growers. The regulatory process is often a limiting factor for a small, individual start-up growers or small-scale restoration projects. The wild shellfish restoration community faces many of the same challenges in the regulatory/permitting process. The CSI is a tool to move towards a collaborative and regional approach to permitting, with leadership from PCSGA, NOAA Fisheries, Corps of Engineers, and CA Dept of Fish and Wildlife, The Nature Conservancy, Regional Water Quality Control Board, and restoration representatives. Offshore opportunities for commercial shellfish production present some of the same challenges as 
nearshore, as well as additional complexities. This overview will touch on the entire suite of opportunities and challenges regarding shellfish in California today.

COMPARATIVE LARVAL PERFORMANCE BETWEEN TETRAPLOID $X$ TETRAPLOID AND TETRAPLOID $X$ DIPLOID CONSTRUCTS USING MOSAIC AND NON-MOSAIC CRASSOSTREA VIRGINICA PARENTS

Brittany Wolfe, Standish Allen

Virginia Institute of Marine Science, College of William and Mary, P.O. Box 1346, Gloucester Point, VA. 23062, USA

Reversion happens and is a concern for polyploidy technology. Ten sets of three crosses were produced using mosaic and nonmosaic Crassostrea virginica tetraploids. Each set consisted of a pair of diploid parents and a pair of tetraploid parents mated in the following way: $2 n$ male $x 4 n$ female $x 4 n$ male $x 2 n$ female. A different pair of tetraploids was used for each set, while the diploid male and female were held constant across all sets. All larvae were reared simultaneously and measured for growth, survival, eyed larvae size, and set rate. Comparisons were made among ploidy combinations ( $3 n$ from $4 n$ egg [ $3 \mathrm{nf}], 3 n$ from $4 n$ sperm [3nm], and $4 n \times 4 n[4 n])$ and between crosses from mosaics or non-mosaic tetraploids. Variation for growth was higher in tetraploid crosses than triploid crosses, but was not different between crosses produced from mosaics and non-mosaics for any ploidy. $3 \mathrm{~nm}$ crosses had higher survival than crosses made from the tetraploid females; survival between $3 \mathrm{nf}$ and $4 \mathrm{n}$ crosses (sharing tetraploid eggs) was significantly correlated. Eyed larvae of $3 \mathrm{nf}$ spawns were significantly larger $(342 \mu \mathrm{m})$ than eyed larvae from $4 \mathrm{n}$ spawns $(330 \mu \mathrm{m})$, in turn, larger than $3 \mathrm{~nm}$ eyed larvae $(310 \mu \mathrm{m})$. There was no difference between mosaic and non-mosaic crosses. Average setting rates were $17 \%$ for $4 \mathrm{n}$ crosses, $20 \%$ for $3 \mathrm{~nm}$, and $25 \%$ for 3 nf, with no significant difference among ploidy types or between mosaic and non-mosaics. The results confirm previous observations on the apparent equivalency of crosses made from mosaic or non-mosaic tetraploids.

CVSI FAMILY OF PROTEASE INHIBITORS IS HIGHLY DIVERSE AND LIKELY EVOLVES ACTIVELY IN MOLLUSCS

Qinggang Xue, Jean-Philippe Béguel, Jerome La Peyre

School of Animal Sciences, Louisiana State University Agricultural Center, Baton Rouge, LA, 70803, USA

The cvSI family of protease inhibitors represents a novel protein family that has been found to play a role in the eastern oyster Crassostrea virginica host defense and resistance to dermo. Two members, cvSI-1 and cvSI-2, have been purified and characterized from the plasma and the third member, cvSI-3, has been identified by cDNA cloning and sequencing. In the present research, the genetic and structural diversities of the protein family were studied. It was found that like cvSI-1 and cvSI-2, cvSI-3 gene was principally expressed in digestive glands. The expression levels of the 3 known cvSI family members significantly differed from each other in the digestive glands. No significant correlations between the levels of gene expression of the $3 \mathrm{cvSI}$ members and the activity of protease inhibition in plasma of the analyzed oysters were detected. A search into sequence databases revealed hundreds of expressed sequence tag (EST) sequences that indicated the existence of at least 9 more potential members of cvSI family in eastern oysters and multiple homologues in several other molluscs including oysters, mussels and abalones. Potential orthologues of all the eastern oyster cvSI members were also identified in the genome of Pacific oysters Crassostrea gigas, with several genes having multiple copies at different genome loci. In addition, preliminary analysis of $C$. gigas genome sequence also generated information about gene structure of the cvSI protease inhibitors. These results indicated that the cvSI family of protease inhibitors is exceptionally diverse in structures and perhaps functions, suggesting a highly active evolution.

\section{CLONING, IDENTIFICATION, AND EXPRESSION OF THE LAP3 GENE IN THE BLOOD CLAM, TEGILLARCA GRAN- OSA}

\section{Hanhan Yao, Yinghui Dong, Zhihua Lin}

Zhejiang Key Laboratory of Aquatic Germplasm Resources, College of Biological and Environmental Sciences, Zhejiang Wanli University, 8 South Qianhu Road, Ningbo, Zhejiang, 315100, China.

Leucine aminopeptidase 3 (LAP3), a member of the M17 family of peptidases, plays important roles in growth and development, stress responses, and adaptation to changes in environmental conditions. Molecular characterization and functions of LAP3 gene has been identified in Crassostrea gigas, but the studies about LAP3 in other mollusks have not been found. In our study, LAP3 gene of Tegillarca granosa (Tg-LAP3) was cloned and expression in adult tissues and embryos/larvae were analyzed. The full length cDNA of Tg-LAP3 gene was 1769bp (GeneBank Accession No. JX103498), containing a complete ORF 1590bp encoding 530 amino acids. The mature Tg-LAP3 possesses two putative conserved domains, N-terminal domain and Peptidase_M17 catalytic domain. The tertiary structure was composed of $15 \alpha$-helixes, 29 $\beta$-sheets and 52 turns. The amino acid sequence of Tg-LAP3 shared $71.6 \%$ similarity with $C$. gigas, and more than $62 \%$ with vertebrates. Tissue-specific expression showed that Tg-LAP3 gene expressed in all tissues (blood, digestive gland, gill, mantle, adductor muscle, foot, testis and ovary), and the highest expression was found in digestive gland $(\mathrm{P}<0.01)$. In different development stages (fertilized eggs, 2-4 cells, blastula, gastrulae, trochophore, Dshaped larvae, umbo larvae, eyebot larvae and juvenile clams), the expression of Tg-LAP3 gene increased gradually with the process 
of development trend, and the highest expression was found in eyebot larvae $(\mathrm{P}<0.01)$, then decreased significantly to juvenile clams $(\mathrm{P}<0.01)$, which suggested that it could be involved in early development.

OCEAN ACIDIFICATION LEADS TO ALTERED MICROMECHANICAL PROPERTIES OF THE MINERALIZED CUTICLE OF JUVENILE RED AND BLUE KING CRABS Aparna Yarram ${ }^{1}$, William D. Coffey ${ }^{1}$, Brian Matoke ${ }^{1}$, W. Christopher Long $^{2}$, Katherine Swiney ${ }^{2}$, Robert Foy ${ }^{2}$, Gary H. Dickinson ${ }^{1}$

${ }^{1}$ The College of New Jersey, Department of Biology, 2000 Pennington Road, Ewing, NJ, 08628, USA

${ }^{2}$ NOAA, National Marine Fisheries Service, Alaska Fisheries Science Center, Resource Assessment and Conservation Engineering Division, Kodiak Laboratory, 301 Research Court, Kodiak, AK, 99615, USA

Ocean acidification (OA) is a decrease in the $\mathrm{pH}$ of the ocean caused by increasing levels of $\mathrm{CO}_{2}$ in the atmosphere. Dissolution of $\mathrm{CO}_{2}$ in ocean water results in decreased $\mathrm{CaCO}_{3}$ saturation states, which may impact the ability of calcifying organisms to build mineralized tissue. Here, the hypothesis that decreasing seawater $\mathrm{pH}$ will result in altered mechanical (microhardness) and structural (thickness and growth increments) properties of the mineralized cuticle was assessed in red and blue king crabs (Paralithodes camtschaticus and P. platypus). Juvenile crabs were exposed for one year to one of two or three levels of $\mathrm{pH}(8.0$ (ambient $\mathrm{pH}$ ) and 7.8 for red king crabs; 8.1 (ambient $\mathrm{pH}$ ), 7.8 and 7.5 for blue king crabs). Following exposures, the chelae and carapace of crabs were dissected, sectioned longitudinally, embedded in epoxy resin and polished. Microhardness (a measure of a material's resistance to deformation) and thickness of individual growth increments (Bouligand structures) were measured within the endocuticle, and thickness of the endocuticle and exocuticle was quantified separately for each sample. In both species, endocuticle microhardness was significantly reduced in the chelae of crabs exposed to low $\mathrm{pH}$, but not in their carapace. In blue king crabs, exocuticle thickness and individual growth increments were significantly reduced in the carapace of crabs exposed to low $\mathrm{pH}$, but not in their chelae. No differences in structural properties among $\mathrm{pH}$ treatments were observed in red king crabs. Such differences may reflect species-specific energetic tradeoffs during the mineralization process under $\mathrm{OA}$.

IMPROVED ANALYSIS OF CROSSBREEDING TRIALS TO INCREASE THE YIELD OF FARMED PACIFIC OYSTERS Xiaoshen Yin, Dennis Hedgecock

University of Southern California, 3616 Trousdale Parkway, AHF 130, Los Angeles, CA, 90007, USA
Hybrid Pacific oysters are high-yielding and tolerant of environmental stresses, implicating crossbreeding of intentionally inbred lines as an important way to improve farmed oyster production (Hedgecock and Davis, 2007). Identifying elite inbred parent lines that produce high-performing hybrid seed requires diallel or factorial test crosses among lines, each acting as both a male and a female parent. The diallel allows variance in yield, among test hybrid families, to be partitioned by ANOVA into causal genetic components-principally, general combining ability, special combining ability, and reciprocal effects. However, ANOVA is extremely sensitive to missing information, which arises, for example, from variation in reproductive success of parent lines. To resolve this issue, we apply a general Bayesian approach, BayesDiallel (Lenarcic et al., 2012), to the analysis of diallel results. Seven BayesDiallel analyses of yield of Pacific oysters at different stages from incomplete diallels provide estimates of combining abilities for all parent lines and all explain more than $95 \%$ of observed yield, suggesting that BayesDiallel is robust to missing information. The analysis of an incomplete diallel was not even possible with ANOVA. In the analysis of yield of Pacific oysters at nearly one-year of age from a complete $5 \times 5$ diallel, $97 \%$ of observed yield is explained by BayesDiallel, compared to $57 \%$ by ANOVA, indicating that BayesDiallel performs better than ANOVA, even in analyzing a complete diallel. Therefore, BayesDiallel can estimate phenotypes of offspring more accurately, regardless of diallel completeness, which will facilitate selection of superior parent lines for producing highyielding, hybrid, Pacific oyster seed.

\section{INTRASPECIES AND INTERSPECIES ABALONE HYBRID- IZATION PRACTICES IN SOUTHERN CHINA: FROM LAB- ORATORY TO INDUSTRY}

Weiwei You, Xuan Luo, Caihuan Ke

College of Ocean and Earth Sciences, Xiamen University, Xiamen 361005, PR China

China is the most important abalone producing countries, while the abalone cultured production reached to 110,380 tons in 2013, which covered more than $80 \%$ of the whole production in the world. Genetic improvement plays an important place in the development of abalone industry in the past decade. Pacific abalone (Haliotis discus hannai) and Small abalone (H. diversicolor) are two commercially important species cultured along the coast of Southern China. A package of projects about genetic breeding on these two abalone species were put forward in 2003. Different geographical population and other species were collected or introduced to establish the abundant germplasm banks, and genetic background was analysed by molecular markers. Then pedigree based inbred lines were built and divergent selection were conducted for several generations. In the other way, complete diallele crosses were conducted among intraspecies and interspecies 
abalone. At last, intraspecies hybridization between two inbred lines of small abalone, which originated from Japan population and Taiwan population, showed exciting heterosis on diseaseresistant ability; while interspecies hybridization between Pacific abalone and $\mathrm{H}$. gigantean showed positive hybrid vigor on summer survival rate. "Dongyou I" small abalone and "Xipan" hybrids were confered for "new species certificate" by Ministry of Agriculture and now are large-scale cultured in China.

\section{RESTORATION OF NATIVE OYSTERS IN A HIGHLY INVADED ESTUARY}

\section{Chela Zabin ${ }^{1}$, Kerstin Wasson ${ }^{2}$, Susanne Fork ${ }^{2}$}

${ }^{1}$ Smithsonian Environmental Research Center and Environmental Science and Policy Department, University of California Davis, 3152 Paradise Drive, Tiburon, CA, 94920, USA

${ }^{2}$ Elkhorn Slough National Estuarine Research Reserve, 1700 Elkhorn Road, Watsonville, CA, 95039, USA

The main method for restoration of native Olympia oysters in California is the provision of hard substrate, which is limited in the state's soft-sediment estuaries. However, many non-native species also require hard substrate and may compete with oysters for settlement space and/or overgrow oysters. At Elkhorn Slough, oysters occur higher in the intertidal zone than many non-native species, particularly sponges and tunicates. In addition, most nonnatives appear to do less well than oysters in muddy locations, and the spread of some non-natives may be limited by short larval duration. Selective placement of restoration substrate could potentially limit the settlement of non-native species while still attracting oysters. As part of a two-year restoration project, we tested the effects on oysters and other sessile species of tidal height, sediment, and distance from adult populations: placing substrates at two tidal elevations $(+0.5 \mathrm{ft}$ and $-0.5 \mathrm{ft})$, in muddy vs. rocky locations, and close to and far from established populations. Oyster settlement was greater at $-0.5 \mathrm{ft}$, but there was no difference in survival by tidal height. There was lower non-native cover (mainly bryozoans, tunicates and sponges) at $+0.5 \mathrm{ft}$. There were no differences in cover of oysters or non-natives at muddy vs. rocky sites, or at locations far from vs. close to adult populations. In this system, substrates placed at higher elevations may give native oysters an advantage over the non-native species. Future research is needed to determine the tidal height that best promotes oyster success while discouraging the spread of non-native species.

\section{RESTORATION OF OLYMPIA OYSTERS, OSTREA LURIDA, IN SOUTHERN CALIFORNIA \\ Danielle C. Zacherl, Shannon Crossen, Cristina M. Fuentes, Andrea Moreno, Thomas Parker \\ Department of Biological Science, California State University} Fullerton, Fullerton, CA, 92831, USA

The Olympia oyster, Ostrea lurida Carpenter, 1864, the only oyster native to the US west coast, has experienced significant population declines since the early 1900s. This once bed-forming species provides complex habitat for other organisms, but natural Olympia oyster beds in southern California are now functionally extinct, making this species the target of recent restoration efforts. We examined which of several restoration techniques would be most effective for restoring $O$. lurida in Newport Bay, CA by constructing replicate $(n=5) 2 \mathrm{~m} \mathrm{X} 2 \mathrm{~m}$ shell beds of two thicknesses ( $4 \mathrm{~cm}$ versus $12 \mathrm{~cm}$ ) and two levels of consolidation (bagged versus loose shell) in a full factorial design, along with 5 un-manipulated beds acting as references. We also examined the effects of a constructed oyster bed on densities of native $O$. lurida and non-native Crassostrea gigas at Jack Dunster Marine Reserve in Alamitos Bay, CA. In both locations, simple augmentation of the habitat with shell resulted in significant increases in oyster density; findings from Newport Bay further indicate that thick shell beds result in higher oyster recruitment, shell \% cover and reduced sedimentation, but level of shell consolidation did not affect any measured response variable. More recent evidence suggests that placement of the shell beds at the correct tidal height may encourage native oyster density increases without concomitant increases in non-native oysters. Scientific monitoring of future $O$. lurida restoration efforts is encouraged, as this study only begins to provide insight into the efficacy of different restoration methods. 